Thaís de CaMargo Rodrigues

\title{
O TRÁFICO INTERNACIONAL DE PESSOAS PARA FIM DE EXPLORAÇÃO SEXUAL E A QUESTÃO DO CONSENTIMENTO
}

\begin{abstract}
Dissertação apresentada ao Programa de Pós-Graduação Stricto Sensu da Faculdade de Direito da Universidade de São Paulo, como parte dos requisitos para a obtenção do título de mestre em direito penal, sob a orientação do Professor Titular Dr. Vicente Greco Filho
\end{abstract}

UNIVERSIDADE DE SÃo PAULO

Faculdade de Direito

São Paulo, 2012 
BANCA EXAMINADORA 
Dedico este trabalho à minha querida avó, Angelina Maria de Camargo (in memoriam), exemplo de dignidade e bondade, qualidades desconhecidas por aqueles que cometem os crimes aqui tratados. 


\section{AGRADECIMENTOS}

O meu agradecimento especial é para meu professor e orientador, Dr. Vicente Greco Filho, que tornou possível minha participação no curso de mestrado e a consequente elaboração desse trabalho. Foi uma honra.

Agradeço a todos os professores da pós-graduação da Faculdade de Direito, especialmente à Janaína Paschoal Conceição, que foi minha professora e também integrou a banca de qualificação. Sua dedicação ao magistério é inspiradora.

Agradeço à querida Dalva, por toda a ajuda e acolhimento, e a todos os meus colegas de turma, em especial ao João Daniel Rassi e ao Marcelo Crespo.

Agradeço a todo o material fornecido pelo Ministério da Justiça, nas pessoas de Guadalupe Nascimento e Maurício Correali, que foram fundamentais para a pesquisa.

Agradeço ao Núcleo de Enfrentamento ao Tráfico de Pessoas do estado de São Paulo, na pessoa de Anália Ribeiro. A dedicação dessa equipe emociona.

Agradeço a todos os profissionais envolvidos com ações de enfrentamento ao tráfico com os quais mantive contato, como a promotora Eliana Vendramini, a antropóloga Adriana Piscitelli, e a jornalista Priscila Siqueira, que me deram relatos valiosíssimos, além de tão gentilmente disponibilizarem seu tempo e material.

Agradeço a todos os meus colegas da Editora Saraiva, que "aguentaram" e compartilharam comigo esses meses de imersão no tráfico de pessoas, enriquecendo o debate e a reflexão. Meu agradecimento especial àqueles que me enviaram textos, atos normativos, filmes e até compraram livros no exterior sobre o tema.

A todos aqueles que tiveram a paciência de ler o texto e me deram dicas valiosas, muito obrigada. 
À querida Silma Madlener, o meu muito obrigada por ter possibilitado o acesso à legislação atualizada dos países europeus.

Agradeço a todos os meus familiares - meu marido, meus pais, meu irmão, meus sogros, cunhados, tios, primos - que compartilharam comigo todos os momentos dessa longa jornada, me incentivando e entendendo a minha ausência.

Um agradecimento especial à Lígia, à Guadalupe, à Daniela, à Aline e ao Leonardo.

Sem esse apoio esse trabalho simplesmente não existiria. Muito obrigada, mesmo. 
"É uma realidade tão espessa, tão viva e tão dramática que nos cobre a todos que, não a querer ver, seria mais do que miopia ética, seria blasfêmia moral".

(In: A globalização e o tráfico de seres humanos: o pêndulo trágico da história e o direito penal.) 


\section{RESUMO}

A presente dissertação, pautada no direito penal mínimo e no princípio da dignidade humana, discorre sobre o tráfico internacional de pessoas para fim de exploração sexual, tendo em vista o consentimento da vítima maior e capaz. Para tanto, foi feita uma análise introdutória do direito penal sexual e da prostituição, buscando identificar o bem jurídico tutelado hodiernamente sem a influência de conteúdo estritamente moral, pois no tráfico de pessoas deve prevalecer a proteção da liberdade sexual. Foram examinados os principais acordos internacionais afeitos à matéria, em especial o Protocolo de Palermo, e também a legislação de países como Alemanha, Portugal, Espanha, Itália, Estados Unidos e Argentina. Neste contexto, fez-se uma leitura crítica da legislação brasileira (mormente o art. 231 do Código Penal), que está em falta com a agenda internacional por se limitar a tutelar o tráfico internacional quando se trata de exploração de índole sexual. Além disso, o dispositivo se mostra falho em sua essência, por não enxergar o tráfico como um fenômeno, um processo delitivo complexo e multifacetado. À ineficácia legislativa se soma a insuficiência das políticas públicas nesta seara para o efetivo enfrentamento do tráfico de pessoas, visando a sua prevenção, punição e também a proteção às vítimas.

PALAVRAS-CHAVE: Tráfico de pessoas. Tráfico internacional de pessoas. Prostituição. Direito penal sexual. Lenocínio. Exploração sexual. Consentimento. 


\begin{abstract}
This paper which is based on the principles of minimum criminal law and human dignity, talks about the international human trafficking for sexual purposes, considering the consent of the adult and capable victim. For this, a preliminary analysis of the criminal sex and prostitution law was made, in order to identify the legal protected property, without the influence of the strictly moral context, because the protection of sexual freedom shall prevail in human trafficking. This paper also evaluates the more important international treaties with regard to this issue, with special regard to the Palermo Protocol as well as the legislation of countries such as Germany, Portugal, Spain, Italy, United States of America and Argentina. A comparative analyses of the Brazilian law was developed (Article 231 of the Brazilian Criminal Code), concluding that the Brazilian law is more restricted than the international rules, because it legislates that Human trafficking is only for sexual purposes and does not consider any other. Besides that, the aforementioned article has a flaw as it does not consider the traffic as a phenomenon, a complex and multifaceted wrongful process. The inefficient Brazilian legislative process is attributed to the insufficiency of public policies in this area to effectively face human trafficking, focusing on its prevention and punishment as well as the protection of the victims.
\end{abstract}

KEY WORDS: Human trafficking. International human trafficking. Prostitution. Criminal Sex Law. Pandering. Sexual exploitation. Consent. 


\title{
LISTA DE ABREVIATURAS
}

\author{
ASBRAD - Associação Brasileira de Defesa da Mulher da Infância e da Juventude \\ CATW - Coalition Against Trafficking in Women \\ CBO - Classificação Brasileira de Ocupações \\ CCJ - Comissão de Constituição e Justiça \\ CPMI - Comissão Parlamentar Mista de Inquérito \\ COE - Conselho da Europa \\ GAATW - Global Alliance Against Traffic in Women \\ IIN - Instituto Interamericano del Niño, la Niña y Adolescentes \\ OIM - Organização Internacional para as Migrações \\ NETP - Núcleo de Enfrentamento ao Tráfico de Pessoas do Estado de São Paulo \\ OEA - Organização dos Estados Americanos \\ OIT - Organização Internacional do Trabalho \\ ONU - Organização das Nações Unidas
}

PESTRAF - Pesquisa sobre Tráfico de Mulheres, Crianças e Adolescentes para fins de

Exploração Sexual Comercial

PL - Projeto de Lei

PNETP - Plano Nacional de Enfrentamento ao Tráfico de Pessoas

PRONASCI - Programa Nacional de Segurança Pública com Cidadania

TIP Report - Trafficking in Persons Report

TPI - Tribunal Penal Internacional

TVPA - Victims of Trafficking and Violence Protection Act

UNESCO - Organização das Nações Unidas para a educação, a ciência e a cultura

UN.GIFT - United Nations Global Initiative to Fight Human Trafficking

UNICEF - Fundo das Nações Unidas para a Infância

UNODC - Escritório das Nações Unidas sobre Drogas e Crime

USAID - United States Agency for International Development

SMM - Serviço à Mulher Marginalizada 


\section{LISTA DE ILUSTRAÇÕES: QUADROS, MAPAS E GRÁFICOS}

Mapa 1 - América (Tier Placements - TIP Repor 2011) ...................................... 73

Mapa 2 - Europa (Tier Placements - TIP Repor 2011) ...................................... 77

Mapa 3 - África e Ásia (Tier Placements - TIP Repor 2011) ............................... 89

Quadro 1 - O tráfico de pessoas no Código Penal e no Protocolo de Palermo........ 97

Quadro 2 - O "fenômeno" tráfico de pessoas ....................................................... 139

Mapa 1 (Anexo) - Mulheres traficadas para a Europa com fim de exploração sexual (cidadania das vítimas detectadas), 2005-2007

Mapa 2 (Anexo) - De onde partem e para onde vão as vítimas

Gráfico 1 (Anexo) - Nacionalidade das vítimas de tráfico detectadas na Europa Ocidental e Central, (\%), 2005-2006

Gráfico 2 (Anexo) - Colombianas, brasileiras e paraguaias vítimas do tráfico na Espanha

Gráfico 3 (Anexo) - Tráfico de trabalho forçado por tipo

Gráfico 4 (Anexo) - Exploração econômica forçada por sexo / Exploração sexual comercial forçada por sexo 


\section{SUMÁRIO}

INTRODUÇÃ̃O

1.1 A INFLUÊNCIA DA MORAL NO DIREITO PENAL SEXUAL

1.2 A DELIMITAÇÃO DO BEM JURÍDICO NO DIREITO PENAL SEXUAL ....................... 24

1.3 OS CRIMES SEXUAIS TUTELADOS PELO CÓDIGO PENAL DE 1940 .......................... 26

1.4 LENOCÍNIO E TRÁFICO DE PESSOAS ..................................................................... 29

1.4.1 Prostituição: proibir, regulamentar ou abolir? ............................................................. $\quad 34$

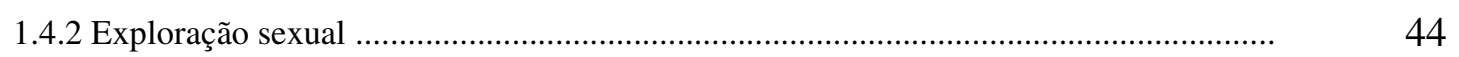

\section{O TRÁfiCO INTERNACIONAL DE PESSOAS PARA FIM DE} EXPLORAÇÃO SEXUAL: EVOLUÇÃO HISTÓRICA

2.1 TRÁFICO DE ESCRAVOS NEGROS

2.2 DO TRÁFICO DE ESCRAVAS BRANCAS AO TRÁFICO DE PESSOAS

2.3 A SOCIEDADE CONTEMPORÂNEA E O TRÁFICO DE PESSOAS PARA FIM DE EXPLORAÇÃO SEXUAL

3.1 DISTINÇÃO ENTRE O TRÁFICO DE PESSOAS PARA FIM DE EXPLORAÇÃO E O TRÁFICO DE MIGRANTES ILEGAIS .

3.2 AMÉRICA

3.2.1 Estados Unidos

3.2.2 América Latina

3.3 EUROPA

3.3.1 Alemanha

3.3.2 Espanha 79

3.3.3 Itália 83

3.3.4 Portugal 86

3.4 ÁFRICA E ÁSIA 88 


\section{O TRÁFICO INTERNACIONAL DE PESSOAS PARA FIM DE EXPLORAÇÃO SEXUAL NO BRASIL.}

4.1 EVOLUÇÃO LEGISLATIVA: DAS ORDENAÇÕES FILIPINAS À REFORMA PENAL DE 2009

4.2 BEM JURÍDICO TUTELADO ………………………………………………….........

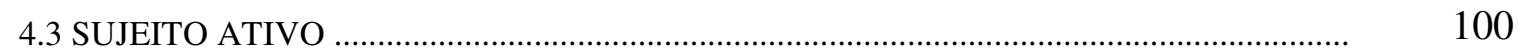

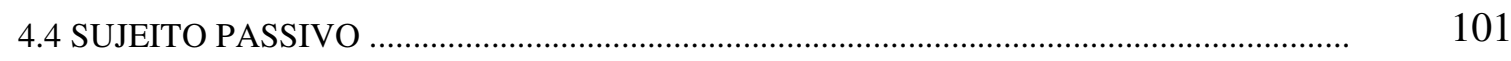

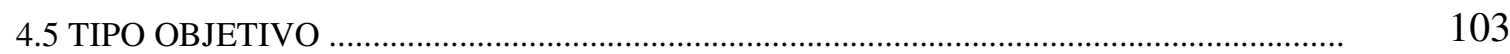

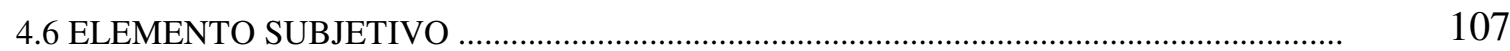

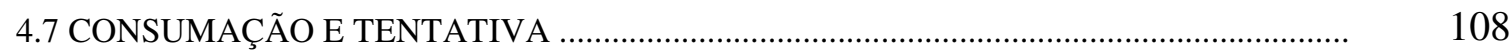

4.8 FINALIDADE DE LUCRO, “LAVAGEM” DE DINHEIRO E CRIME ORGANIZADO ..... 109

4.9 AÇÃO PENAL E COMPETÊNCIA …………………............................................................ 113

4.9.1 Competência do Tribunal Penal Internacional e Cooperação Jurídica Internacional ....... 113

\section{ANÁLISE CRÍTICA DA LEGISLAÇÃO BRASILEIRA REFERENTE AO TRÁFICO DE PESSOAS}

5.1 LEGISLAÇÃO PENAL BRASILEIRA $x$ PROTOCOLOS ADICIONAIS À CONVENÇÃO DE PALERMO: A OBRIGAÇÃO DE CRIAR TIPOS PENAIS E AS PROPOSTAS PARA A ALTERAÇÃO DA LEGISLAÇÃO BRASILEIRA

5.2 ANÁLISE CRÍTICA DO CONCENITO LEGAL DE TRÁFICO INTERNACIONAL DE PESSOAS PARA FIM DE EXPLORAÇÃO SEXUAL: MAIS QUE UM CRIME, UM VERDADEIRO "FENÔMENO"

6.1 DEPOIMENTOS

6.1.1 Maya, 15 anos, nepalesa

6.1.2 Simone, 25 anos, brasileira

6.1.3 Nadia, 22 anos, moldávia

6.1.4 Rath, 15 anos, cambojana ..... 
CONCLUSÕES

ANEXO - Mapas e Gráficos

REFERÊNCIAS 


\section{INTRODUÇÃO}

Passada a primeira década do século XXI ainda nos deparamos com situações que causam perplexidade, como o "comércio" de seres humanos visando inúmeras formas de exploração, seja sexual, do trabalho, em conflitos bélicos ou para a remoção de órgãos.

O denominado tráfico de seres humanos, a despeito de constituir verdadeiro vilipêndio à dignidade humana, é um fenômeno real, e se apresenta de forma multidisciplinar e complexa. As causas são diversas: não há um modelo padrão de aliciamento, nem um tipo específico de modus operandi. Além disso, existem graus diferentes de exploração, que oferecem desde uma relativa liberdade à vítima até sua completa escravização.

O tráfico de pessoas para fim de exploração sexual se imiscui com uma série de outros fenômenos, como o contrabando de migrantes, a prostituição voluntária no exterior, a exploração sexual comercial de menores, o trabalho escravo, a indústria pornográfica, o turismo sexual e outros serviços de cunho sexual.

Embora desde o advento do Protocolo de Palermo ${ }^{1}$ o assunto esteja nas pautas de discussão há algum tempo, tanto no cenário internacional quanto no nacional, existem ainda muitas questões controvertidas, especialmente as relacionadas aos conceitos, ao bem jurídico e às estatísticas.

A dificuldade em delimitar o fenômeno não deve ser obstáculo para traçar suas principais características, com o fim de melhor compreendê-lo e assim oferecer respostas jurídicas ou sociais mais efetivas. É nesse contexto que se propõe a análise do tráfico internacional de pessoas adultas para fim de exploração sexual, com destaque para a questão do consentimento. Não obstante admitido no Protocolo de Palermo (art. $3^{\circ}, b$ ), o consentimento de pessoa maior e capaz é ignorado na legislação brasileira vigente (art. 231 do Código Penal).

\footnotetext{
${ }^{1}$ O Protocolo de Palermo entrou em vigor em 29-9-2003, e, no Brasil, em 28-2-2004. Foi promulgado pelo Decreto n. 5.017, de 12-3-2004 (Protocolo adicional à Convenção das Nações Unidas contra o crime organizado transnacional relativo à prevenção, repressão e punição do tráfico de pessoas, em especial mulheres e crianças).
} 
Com base em pesquisa bibliográfica e documental sobre a matéria, inclusive da ONU e de seus organismos internacionais, bem como na leitura de depoimentos de vítimas, agentes públicos e associações civis, a abordagem deste trabalho visa uma análise crítica do fenômeno. Não uma denúncia irrefletida e destemperada, mas ampla, buscando entender as diversas vertentes e posicionamentos.

O estudo está dividido em sete capítulos. Inicia-se com a análise do direito penal sexual, que durante os últimos anos sofreu inúmeras alterações no Brasil e no exterior, a maioria delas procurando afastar o caráter vetusto que permeia a matéria, e também redescobrir o bem jurídico que efetivamente deve ser tutelado.

Ainda em caráter introdutório, traça-se um panorama histórico-legislativo do tráfico sexual, começando com a escravidão negra, passando pelo tráfico de escravas brancas até culminar no tráfico conhecido hoje, tutelado pelo Protocolo de Palermo.

Em seguida examina-se a situação do tráfico no exterior, bem como a legislação relacionada à matéria em alguns países, como Alemanha, Argentina, Espanha, Estados Unidos, Itália e Portugal.

Na sequência analisa-se a legislação brasileira acerca do tráfico, em especial o art. 231 do Código Penal. Com base nas correntes doutrinárias acerca do tema, são avaliados o bem jurídico tutelado, o tipo objetivo, os sujeitos ativo e passivo, a consumação e a tentativa e também a competência para julgar o delito, incluindo um breve estudo sobre o Tribunal Penal Internacional.

O Capítulo 5 tem por escopo uma visão crítica acerca da legislação brasileira em vigor (ou sua ausência) com relação ao Protocolo de Palermo. Oferece um panorama sobre os dispositivos do Código Penal e da legislação esparsa aplicáveis ao tráfico de pessoas em sentido lato, abrangendo todas as formas de exploração, e também ao contrabando de migrantes. Neste ponto são avaliados também os projetos de lei sobre a matéria que tramitam no Congresso Nacional.

A crítica é feita com base no direito penal mínimo e almejando a tutela do tráfico de forma sistêmica e proporcional, de acordo com a agenda internacional. $O$ tráfico de 
pessoas não se esgota em um dispositivo penal; é um fenômeno que requer proteção ampla e eficaz.

Nesse diapasão, examina-se no capítulo seguinte a política de enfrentamento ao tráfico de pessoas no Brasil, com fulcro no tripé prevenção do delito, punição dos criminosos e proteção das vítimas. Além da apresentação de depoimentos impressionantes, são trazidas à luz as mazelas que contribuem para o aumento da prática desse delito: a indiferença social, a falta de acesso à educação, o desemprego, a ausência de oportunidades nos países de origem, a corrupção, as questões de gênero, a baixa qualificação dos agentes públicos.

O status inferior de mulheres e meninas em muitas partes do mundo tem contribuído para que sejam elas as maiores vítimas na crescente indústria do tráfico. Tratase de um negócio muito lucrativo, uma atividade ilícita mais simples e mais rentável que o tráfico de drogas, por exemplo. A mulher em si não é uma "mercadoria" ilícita, e pode ser "utilizada" inúmeras vezes.

Nos casos mais graves as escravas sexuais são forçadas a servir a centenas ou até mesmo a milhares de "clientes" antes de serem descartadas, morrerem ou conseguirem fugir. A submissão é obtida por meio de violência, estupro, tortura, fome, prisão, ameaças, abuso psicológico e coerção. Mesmo assim, é curioso observar que muitas mulheres ou transexuais não se veem como vítimas de um crime.

Por fim, propõe-se uma mudança de paradigma com relação à questão específica do consentimento, tanto ao legislador como ao operador do direito, e a consequente reforma legislativa.

Avalia-se, nesse contexto, se é possível considerar válido o consentimento da pessoa maior e capaz visando a não incidência do crime, ou, caso contrário, se se estaria diante de uma intervenção excessivamente paternalista do Estado brasileiro. O impacto da situação de vulnerabilidade da vítima no consentimento também será examinado. 
Cada vez mais este tema atrai a atenção da opinião pública, da imprensa, de governantes e líderes de todos os continentes, provocando reflexões no meio acadêmico e discussões nos principais foros internacionais.

O intento dessa dissertação é contribuir para a discussão acerca desse crime brutal, uma vez que somente conhecendo o fenômeno se conseguirá enfrentá-lo de maneira eficaz. 


\section{O DIREITO PENAL SEXUAL}

Esta dissertação tem por escopo tratar do tráfico internacional de pessoas para fim de exploração sexual, com fulcro na dignidade humana e no direito penal mínimo.

Antes de abordar o tema principal, julga-se oportuno situar a matéria, para analisála em um contexto próprio, com suas peculiaridades.

O estudo do direito penal sexual é, para tanto, imprescindível, uma vez que se trata de ramificação ${ }^{2}$ do direito penal em plena evolução, sempre afligida por intervenções morais e religiosas e, mais recentemente, também por movimentos feministas, todos obstáculos a uma exegese mais racional.

O movimento pendular da história demonstra os avanços e retrocessos das questões envolvendo a sexualidade. Para exemplificar, pode-se citar a homossexualidade na Grécia e Roma antigas, vista com naturalidade e até como uma conduta saudável, especialmente a masculina entre anciões e jovens. Ainda na Antiguidade, relembre-se também a produção de pinturas e estátuas eróticas, como as encontradas nos escombros de Pompeia. Da relativa liberdade passa-se à forte repressão imposta pela Igreja no campo da sexualidade durante a Idade Média, que recriminava até o pensamento e o desejo. O sexo só era admitido entre pessoas casadas e para o fim específico da procriação. Embora a influência religiosa tenha sido relativizada, com exceção dos países teocratas, ainda hoje a religião influencia as questões que envolvem a sexualidade. Neste passo, não obstante se tenha presenciado a revolução sexual na segunda metade do século $\mathrm{XX}$, nos dias atuais se enfrenta uma pesada carga moral em questões relacionadas ao gênero, homofobia, prostituição e pornografia.

A consequente tipificação das condutas ligadas ao sexo e sua interpretação retratam a visão da sociedade em dado momento histórico-cultural. É o que se passa a discutir.

\footnotetext{
${ }^{2}$ Sobre o estudo compartimentado do direito penal: SILVEIRA, Renato de Mello Jorge. Crimes sexuais: bases críticas para a reforma do direito penal sexual, p. 25-36. Para o autor, todas as derivações do direito penal detêm a mesma base dogmática, mas o direito penal sexual carece de estudo autônomo, com um leque de particularidades.
} 


\subsection{A INFLUÊNCIA DA MORAL NO DIREITO PENAL SEXUAL}

Miguel Reale persegue, ao longo da obra Filosofia do Direito, a distinção entre moral e direito. Afirma o autor que essa questão não surgiu de maneira precisa e plena, mas sim como "resultado dos acontecimentos históricos e do progresso verificado na categorização lógica da ciência do direito"3.

Ao final do livro, o autor apresenta um esquema ${ }^{4}$ que traz as principais diferenças entre a moral e o direito. Para ele, a moral visa o bem individual ou os valores da pessoa, sendo incoercível. Já o direito se apresenta como coercível, e objetiva os bens sociais ou valores da convivência. Não obstante essas diferenças, em diversos momentos direito e moral se entrelaçam.

A análise da influência da moral $^{5}$ no direito penal é tema obrigatório quando se fala em delitos sexuais. Verificar-se-á a seguir que, ao longo dos séculos, esses delitos foram tutelados, refletindo valores, costumes e a moral sexual vigentes.

A moral sexual pode ser entendida como a parte da moral que trata das manifestações sexuais na coletividade. No mundo antigo, especificamente em Roma, não havia grande preocupação em tipificar as condutas morais. Até o século VIII a censura dessas condutas cabia ao pater familias ${ }^{6}$.

Já na Idade Média, a moral sexual passou a ser a ditada pela Igreja Católica. Expoente desse período, Tomás de Aquino condenava a luxúria, o adultério, o incesto e a homossexualidade ${ }^{7}$.

\footnotetext{
${ }^{3}$ REALE, Miguel. Filosofia do direito, p. 711-713.

${ }^{4}$ Idem, p. 712 .

${ }^{5}$ Segundo Luiz Vicente Cernicchiaro, em seu Dicionário de direito penal, p. 334, a moral constitui um "sistema normativo que disciplina a conduta dos homens", tendo características específicas a despeito de outros sistemas, como a religião, a política ou o direito. Para o autor a norma moral revela unilateralidade (limita-se a impor deveres), autonomia (não subjuga a vontade do destinatário), não é coercitiva e se aplica à vida interior. Para De Plácido e Silva, em seu Vocabulário jurídico, v. III, p. 210, a moral tem âmbito mais amplo que o direito, "escapando à ação deste muitas de suas regras".

${ }^{6}$ VON LISZT, Franz. Tratado de direito penal alemão, p. 113.

${ }^{7}$ Suma Teológica, Parte II, questão 154 - espécies de luxúria (séc. XIII).
} 
Essa moral não se impôs de imediato, mas foi-se construindo e enrijecendo de forma gradativa ${ }^{8}$, reprimindo desde as relações sexuais fora do casamento ou sem fins de procriação ${ }^{9}$ até os meros pensamentos ou desejos.

O Renascimento propiciou significativas mudanças sociais, mas a repressão nas questões sexuais continuava intensa, ainda influenciada pela Igreja.

Para Von Liszt ${ }^{10}$, a enorme extensão dos delitos contra a moralidade produziu um movimento de reação no curso do século XVIII, sob a influência do Iluminismo, representada por Voltaire, Hommel, Cella e Soden. A reivindicação consistia em reduzir as penas, pois, segundo Von Liszt, "tais delitos não ofendem a ninguém nem põem o Estado em perigo". Porém, foi somente a partir da década de 60 do século XX que o Ocidente enfrentou uma mudança brusca de paradigmas nesse campo.

No Brasil, para analisar a influência da moral no direito penal sexual, deve-se partir do Livro V das Ordenações Filipinas, de 1603. Nessa norma, pautada na intimidação pelo terror, crime e pecado se confundiam. A moral sexual fomentada pela Igreja durante a Idade Média fica evidente nos títulos XIV a XXXIV das Ordenações. Alguns delitos eram discriminatórios, inquisitoriais, como o praticado pelo infiel que $\underline{\text { dormisse }}^{11}$ com alguma cristã, punido com a pena capital. Outros demonstravam total invasão da esfera privada pelo Estado, como dormir consensualmente com mulher virgem ou viúva honesta; dormir com mulher casada; e até mesmo o homem se vestir em trajes de mulher ou a mulher em trajes de homem. Existiam também os crimes graves, como o praticado por aquele que dormisse por força com qualquer mulher, que corresponderia atualmente ao estupro.

Essa legislação vigorou até 1830, com o advento do Código do Império, no qual o capítulo dos crimes contra a segurança da honra cuidava da matéria. No Código Republicano, de 1890, encontra-se a tutela desses delitos no título dos crimes contra a segurança da honra e honestidade das famílias e do ultraje público ao pudor.

\footnotetext{
${ }^{8}$ GRECO, Alessandra Orcesi Pedro; RASSI, João Daniel. Crimes contra a dignidade sexual, p. 12.

${ }^{9}$ SILVEIRA, op. cit., p. 126.

${ }^{10}$ VON LISZT, op. cit., p. 115.

${ }^{11}$ Note-se o uso do verbo dormir como eufemismo para o ato sexual.
} 
Pela denominação citada nos dois Códigos, verifica-se que o bem jurídico tutelado era a honra, que deve ser interpretada na concepção admitida pela moral vigente, buscando assegurar a honestidade das famílias no aspecto sexual. A liberdade sexual era posta em segundo plano.

A postura defendida por Chrysólito de Gusmão ${ }^{12}$, no início do século XX, reflete a importância da moral sexual para a legislação brasileira da época:

A moral sexual é a base, o substractum de todo o edifício da moral, ou, antes, é a sua viga mestra, ela se dilui, se mescla, invade e influencia, mais ou menos, direta ou indiretamente, mediata ou imediatamente, em forma inicialmente propulsora ou reflexa, todos os demais campos da moral social.

O Código Penal de 1940, em sua versão original, tratava dos crimes contra os costumes, impondo o que deveriam ser os bons costumes para a sociedade. Apenas em 2009 a denominação do referido título passou a crimes contra a dignidade sexual.

Magalhães Noronha ${ }^{13}$, ao comentar os crimes contra os costumes previstos no Código de 1940, afirmava que o Estado não poderia ser indiferente à tutela da moralidade pública e dos bons costumes. Para esse autor, a defesa dos costumes pelo direito penal se mostrava como "mínimo da ética sexual” exigido na vida em sociedade.

Em sentido contrário, Hart ${ }^{14}$ alega que mesmo a moral positiva sustentada por uma esmagadora maioria não está imune à crítica. Dentro de uma mesma sociedade os aspectos morais variam ${ }^{15}$ conforme a faixa etária, a opção religiosa, o histórico familiar.

Segundo Sérgio de Oliveira Médici ${ }^{16}$, a objetividade jurídica desse Código não visava proteger a pessoa da mulher, mas sua virgindade, sua honestidade, seu estado civil. Isso fica claro com as referências à mulher virgem, honesta, casada. No entendimento do autor, a tutela penal dirigia-se, na verdade, aos interesses masculinos (do marido ou do pai da vítima) e à moral social.

${ }^{12}$ GUSMÃO, Chrysólito Chaves de. Dos crimes sexuais, p. 71.

${ }^{13}$ NORONHA, E. Magalhães. Direito penal, p. 60 e 64.

${ }^{14}$ HART, H. L. A. Direito, liberdade e moralidade, p. 96.

${ }^{15}$ SILVEIRA, op. cit., p. 124.

16 MÉDICI, Sérgio de Oliveira. A condição feminina na reforma penal projetada de 1999. In: REALE JÚNIOR, Miguel; PASCHOAL, Janaína (Coord.). Mulher e direito penal, p. 365. 
Como exemplo, pode-se citar alguns delitos na redação original do Código Penal de 1940. Para o estupro a pena era de 3 a 8 anos; para o atentado violento ao pudor, de 2 a 7 anos; para o tráfico de mulheres, a pena também era de 3 a 8 anos.

Comparando estupro e atentado violento ao pudor, embora a violência possa ser considerada de mesma intensidade, apenas no caso do estupro ela poderia gerar uma gravidez indesejada, fora do casamento. Daí a pena ser maior. Entre estupro e tráfico de mulheres, fica clara a prevalência da proteção aos costumes, já que o primeiro é cometido de forma violenta, e o último, na figura do caput, pode ser praticado com o consentimento da vítima. Essa diferença denota a intenção do legislador de sobrepor os bons costumes à liberdade individual.

Doutrinadores contemporâneos tecem severas críticas a qualquer aspecto moralista ou religioso presente na legislação penal. O Brasil é um Estado laico, democrático e pluralista, portanto não pode admitir a tutela de bens jurídicos baseada exclusivamente na moral social e nos bons costumes. Segundo Manuel da Costa Andrade ${ }^{17}$, o direito penal sexual ainda sobreviveria como uma ilha num mundo já marcado pela secularização.

Para Jorge de Figueiredo Dias ${ }^{18}$, "não é função do direito penal nem primária, nem secundária tutelar a virtude ou a moral: quer se trate da moral estadualmente imposta, da moral dominante, ou da moral específica de um grupo social". Esse autor considera que a concepção material de crime pautada na perspectiva moral ético-social é absolutamente inadequada à estrutura e às exigências das sociedades democráticas e pluralistas de nossos dias.

Natscheradetz ${ }^{19}$ ensina que o direito e a moral não são dois círculos concêntricos, sendo o do direito representado pelo de diâmetro menor. $\mathrm{O}$ autor português entende que a interpretação correta sejam "dois círculos cujos centros estão separados - embora por vezes tais círculos se entrecruzem". Para ele, o direito e a moral constituem fatos institucionais distintos, seja em suas fontes ou no sistema de sanções.

\footnotetext{
${ }^{17}$ COSTA ANDRADE, Manuel da. Consentimento e acordo em direito penal, p. 386.

${ }^{18}$ DIAS, Jorge de Figueiredo. Direito penal: parte geral, p. 112.

${ }^{19}$ NATSCHERADETZ, Karl Prelhaz. $O$ direito penal sexual: conteúdo e limites, p. 66.
} 
Nesse sentido, pode-se entender a moral, com Renato Silveira ${ }^{20}$, como base ou referencial ao espectro maior do direito penal. Porém, alerta o autor que a tese do lastro dos conteúdos morais não deve prevalecer, "fazendo com que o discurso sectário de alguns venha a se edificar como figuras típicas que não agridem a bens jurídicos concretos". Para ele, os conteúdos morais que já sustentaram a formação do direito penal não podem mais ser motivadores de sanções ${ }^{21}$.

Países como a Alemanha, após a reforma de 1973, e a Espanha, depois da reforma de 1989, passaram a tutelar penalmente a liberdade de autodeterminação sexual das pessoas e não a moral pública.

No Brasil se pode citar as duas reformas do Código Penal referentes à matéria, ocorridas em 2005 e 2009. A reforma de 2005, perpetrada pela Lei n. 11.106, pode ser considerada um marco para o direito penal sexual. Figuras como a da mulher honesta, ou a da extinção da punibilidade baseada no casamento do autor do delito ou de terceiro com a vítima, há muito criticadas pela doutrina, foram extirpadas do direito brasileiro ${ }^{22}$. Nesse passo, o crime previsto no art. 231 - tráfico de mulheres - foi substituído pelo tráfico internacional de pessoas, englobando também os homens, embora ainda representem a minoria.

A reforma de 2009, realizada pela Lei n. 12.015, trouxe como grande avanço a alteração da denominação do título de Crimes contra os Costumes para Crimes contra a Dignidade Sexual, tendo em vista o princípio da dignidade humana, substrato de um Estado Democrático de Direito.

Ante o exposto, e conforme se verá ao longo deste trabalho, a moralidade se faz presente nos delitos sexuais até os dias de hoje. Não há como dizer que esses preceitos não estejam arraigados na elaboração dos tipos penais. Entretanto, paulatinamente, progressos são percebidos.

\footnotetext{
${ }^{20}$ SILVEIRA, op. cit., p. 124.

${ }^{21}$ Idem, p. 146.

${ }^{22}$ Segundo Renato Silveira "a simples retirada de expressões, como se fez pretender, ainda não basta para uma reforma ideal”. In: Crimes sexuais, p. 59.
} 


\subsection{A DELIMITAÇÃO DO BEM JURÍDICO NO DIREITO PENAL SEXUAL}

Como se observou, o direito penal sexual sempre sofreu influência da moral na tipificação dos delitos. Neste tópico se buscará a delimitação do bem jurídico penal sexual tendo por base um direito penal mínimo e os princípios da lesividade, subsidiariedade e fragmentariedade. Em um Estado Democrático de Direito não há lugar para a tutela penal de questões estritamente morais.

Adota-se neste trabalho a posição doutrinária segundo a qual a finalidade do direito penal é a proteção subsidiária de bens jurídicos. Como ensina Roxin ${ }^{23}$, bens jurídicos são todos os dados pressupostos de um convívio pacífico entre os homens, fundado na liberdade e na igualdade. Para esse autor ${ }^{24}$, "a imoralidade ou a reprovabilidade ética de um comportamento não podem legitimar uma proibição penal, se os pressupostos de uma convivência pacífica não forem lesionados".

Na seara penal protegem-se, então, apenas certos bens jurídicos e, ainda assim, contra determinadas formas de agressão ${ }^{25}$. Nas palavras de Janaína Paschoal ${ }^{26}$, o Estado Democrático de Direito deve buscar um "Direito Penal efetivamente limitado à lesão de bens jurídicos caros à sociedade".

Para Natscheradetz ${ }^{27}$, "o fato de existir um comportamento que seja do ponto de vista ético-social quase unanimemente censurado não significa que o direito, e muito em particular o direito penal, deva intervir".

Afirma Daniel de Resende Salgado ${ }^{28}$ que entender que o bem jurídico tutelado é a moralidade pública reforça a existência de um sistema calcado em valores falocráticos e marcado pelo falso moralismo, remanescente de preconceitos patriarcalistas.

\footnotetext{
${ }^{23}$ ROXIN, Claus. Que comportamentos pode o estado proibir sob ameaça de pena? Sobre a legitimação das proibições penais. In: ROXIN, Claus. Estudos de direito penal, p. 31.

${ }^{24}$ Idem, p. 37.

${ }^{25}$ TOLEDO, Francisco de Assis. Princípios básicos de direito penal, p. 17.

${ }^{26}$ PASCHOAL, Janaína Conceição. Constituição, criminalização e direito penal mínimo, p. 43.

${ }^{27}$ NATSCHERADETZ, op. cit., p. 79.

${ }^{28}$ SALGADO, Daniel de Resende. O bem jurídico tutelado pela criminalização do tráfico internacional de seres humanos. Disponível em: <http://www.prsp.mpf.gov.br/prdc/area-de-atuacao/escravidao-e-trafico-deseres-humanos>. Acesso em: 13 dez. 2011.
} 
Nada impede, contudo, que o bem jurídico tutelado seja também moralmente relevante. Nesse sentido, Santiago Mir Puig ${ }^{29}$ afirma que, segundo o postulado da exclusiva proteção de bens jurídicos, não podem ser tutelados pelo direito penal interesses meramente morais. Mir Puig alerta, porém, que os bens jurídicos penais podem ser bens morais, exigindo-se "que tenham algo mais que os tornem merecedores da proteção jurídico-penal”.

De acordo com Luís Greco ${ }^{30}$, o qual questiona o motivo de se recusar a incriminação de meras convicções morais, o que interessa, em primeiro lugar, "não é nem que a proteção da moral pelo direito penal seja de reduzida eficácia, nem que ela produza poucos benefícios, e sim a sua incompatibilidade com o respeito pela autonomia dos cidadãos". Para ele, em certas esferas o cidadão é soberano absoluto.

Nesse contexto, Natscheradetz $z^{31}$ afirma que na órbita sexual a liberdade individual apresenta especial relevo, pois se trata do direito à livre opção e autodeterminação na esfera privada, o que autoriza o agente a "atuar de acordo com os seus gostos, temperamento e personalidade, na execução do seu projeto de vida, tal como noutras esferas pessoais e privadas da sua existência".

Assim, quando se fala em delitos como rapto, adultério, sedução, rufianismo, mediação para servir à lascívia de outrem, todos entre maiores capazes que consentiram na conduta, não se vislumbra um bem jurídico a ser tutelado criminalmente.

Para Renato Silveira ${ }^{32}$, o direito penal sexual deve limitar-se essencialmente à proteção de menores e a evitar condutas violentas, pois a moral não é um bem jurídico. Pode parecer imoral para algumas pessoas a conduta do rufião que se deixa sustentar consensualmente por uma prostituta maior e capaz. No entanto, essa conduta não deveria

\footnotetext{
${ }^{29}$ MIR PUIG, Santiago. Direito penal: fundamentos e teoria do delito, p. 95.

30 GRECO, Luís. Tem futuro a teoria do bem jurídico? Reflexões a partir da decisão do Tribunal Constitucional Alemão a respeito do crime de incesto (§ 173 Strafgesetzbuch). Revista Brasileira de Ciências Criminais, p. 178.

${ }^{31}$ NATSCHERADETZ, op. cit., p. 42.

32 SILVEIRA, Renato de Mello Jorge. Por um novo Direito Penal Sexual. Revista Brasileira de Ciências Criminais, p. 143-144.
} 
ser considerada ilegal, uma vez que ambos agem dentro de sua esfera de liberdade, sem prejudicar terceiros.

Díez Ripollés ${ }^{33}$ acredita que a liberdade sexual tenha se consolidado nas últimas décadas como o objeto de proteção que justifica as intervenções jurídico-penais nas práticas sexuais dos cidadãos. A intervenção penal se faz justamente para que toda pessoa exerça a atividade sexual em liberdade, homem ou mulher.

Assim, adota-se para este trabalho a liberdade sexual como o bem jurídico a ser tutelado nos delitos sexuais entre maiores capazes, considerada forma de exteriorização do princípio da dignidade humana.

\subsection{OS CRIMES SEXUAIS TUTELADOS PELO CÓDIGO PENAL DE 1940}

O Código Penal de 1940 trata dos delitos sexuais no Título VI - Dos Crimes contra a Dignidade Sexual, que abrange os arts. 213 a 234-C. Pode-se dividir esse título em quatro grupos distintos: os crimes cometidos mediante violência, grave ameaça, constrangimento ou fraude; os crimes cometidos contra vulnerável; o ultraje público ao pudor; e o lenocínio.

Discorrer-se-á brevemente sobre os tipos penais sexuais, observando que muitos deles são vagos, com elementos normativos que admitem interpretações díspares. O ideal seria uma interpretação teleológica, nos termos dos mandamentos constitucionais ${ }^{34}$. Tendo em vista que a Constituição Federal de 1988 consagra a liberdade individual, para o Estado não importa a maneira como cada pessoa conduz sua vida sexual.

A denominação dada a um título ou capítulo do Código tem como uma de suas finalidades direcionar a análise de cada figura típica nele contida, pois, seja mediante a interpretação sistêmica ou teleológica, pode-se definir qual bem jurídico se quer proteger e

\footnotetext{
${ }^{33}$ DÍEZ RIPOLLÉS, José Luis. El objeto de protección del nuevo derecho penal sexual. Revista de Derecho Penal y Criminología, p. 69.

${ }^{34}$ SILVEIRA, Renato de Mello Jorge. Crimes sexuais, p. 40-41.
} 
de que forma ${ }^{35}$. Assim, todos os delitos previstos no Título VI do Código Penal brasileiro devem ter como norte a dignidade sexual.

$\mathrm{O}$ bem jurídico dignidade sexual está bem distante dos bons costumes de outrora. $\mathrm{O}$ primeiro não deve envolver juízo de valoração subjetivo, pois, na esfera privada cada um pode agir como melhor lhe aprouver ${ }^{36}$.

Feitas as observações iniciais, analisar-se-á os quatro grupos mencionados. O primeiro deles, que se encontra no capítulo dos crimes contra a liberdade sexual, criminaliza os delitos de estupro (art. 213), violação sexual mediante fraude (art. 215) e assédio sexual (art. 216-A).

Comentando tais delitos, Renato Silveira ${ }^{37}$ afirma que somente a violência e a grave ameaça devem justificar a presença da intervenção penal.

O delito mais importante e mais grave desse grupo é o estupro. Desde a reforma de 2009 ele açambarcou as condutas previstas no atentado violento ao pudor, que foi revogado. O estupro, crime violento por natureza, deve sofrer uma reprimenda penal proporcional à lesão. Porém, ainda se encontram julgadores que avaliam a participação da vítima nesse delito de forma discriminatória, como se ela tivesse "provocado" o agente. Trata-se de uma questão da revitimização, seja durante o inquérito ou o processo penal: quando não acreditam na história da vítima, exigem que ela prove sua história, ou inferem que poderia ter feito outra escolha. Fica evidente que a questão do gênero está longe de ser resolvida.

O segundo grupo encontra abrigo no capítulo referente aos crimes sexuais contra vulnerável. São tipificados: o estupro de vulnerável (art. 217-A), a mediação para criança ou adolescente servir à lascívia de outrem (art. 218) ${ }^{38}$, a satisfação de lascívia mediante presença de criança ou adolescente (art. 218-A) e o favorecimento da prostituição ou outra forma de exploração sexual de vulnerável (art. 218-B).

\footnotetext{
${ }^{35}$ GRECO, Rogério. Curso de direito penal, v. III, p. 449.

${ }^{36}$ NUCCI, Guilherme. Crimes contra a dignidade sexual, p. 140.

${ }^{37}$ SILVEIRA, op. cit., p. 365.

38 A Lei n. 12.015, de 2009, suprimiu o nomen juris desse artigo, que anteriormente era corrupção de menores.
} 
Somem-se a esses delitos os previstos pelo Estatuto da Criança e do Adolescente, como os arts. 240 a 241-E e 244-A (pornografia infantil, pedofilia na Internet, prostituição ou exploração sexual).

Segundo lecionam Alessandra Greco e João Daniel Rassi ${ }^{39}$, no tocante aos crimes mencionados, o bem jurídico protegido é o bem-estar psíquico do menor e do incapaz, visando um adequado processo de formação desses sujeitos.

No terceiro grupo encontram-se o ato obsceno (art. 233) e o escrito ou objeto obsceno (art. 234), ambos sob a rubrica do ultraje público ao pudor.

O crime de ato obsceno suscita inúmeros debates na doutrina. Se, por um lado, merece ser revogado, por apresentar elemento normativo de índole valorativa e de difícil delimitação, considerando os hábitos sociais, os costumes locais, que variam com muita rapidez no tempo e no espaço, por outro lado a descriminalização absoluta deixaria ao desamparo a pessoa que tivesse a liberdade sexual (compreendida em sua dimensão negativa) violada em face de determinadas condutas que reclamam a tutela penal, como presenciar uma cena de sexo explícito em praça pública à luz do dia ${ }^{40}$.

Natscheradetz ${ }^{41}$, ao discorrer sobre locais públicos, afirma que as pessoas possuem o direito a não serem confrontados com ações sexuais sem o seu consentimento, e, se o forem, estar-se-á perante uma ofensa a sua liberdade.

Segundo lição de $\mathrm{Hart}^{42}$, nesse caso a afronta seria à decência pública. O autor menciona dois exemplos: o primeiro diz respeito à relação sexual entre um homem e uma mulher casados. Para Hart, essa relação não é imoral, mas, se ocorrer em local público, "constitui uma afronta à decência pública". O segundo exemplo refere-se a um casal homossexual. Afirma Hart que a relação homossexual entre adultos capazes, na intimidade, é considerada imoral do ponto de vista da moral convencional, mas não se apresenta como insulto ou afronta à decência pública. Isso apenas ocorreria se o fato se desse em público.

\footnotetext{
${ }^{39}$ GRECO e RASSI, op. cit., p. 75.

${ }^{40}$ FRANCO, Alberto Silva; STOCO, Rui (coords.). Código Penal e sua interpretação, p. 1155.

${ }^{41}$ NATSCHERADETZ, op. cit., p. 59.

${ }^{42}$ HART, op. cit., p. 67.
} 
Embora os exemplos tenham forte cunho moral, não se olvide que Hart escreveu sua obra em 1963. Assim, o que deve ser verificado é que o Estado não pode intervir na esfera privada das pessoas, por mais que algum grupo considere imoral determinada conduta, porém, quando esta se der em público, tendo em vista a liberdade sexual (negativa), o Estado pode intervir, e não necessariamente por meio do direito penal.

No tocante ao delito do art. 234 , a doutrina ${ }^{43}$ inclina-se a considerar essa infração superada, especialmente a partir da vigência da Constituição Federal de 1988, que elimina toda forma de censura (art. $5^{\circ}$, IX).

O último grupo, que dispõe sobre as formas de lenocínio, será analisado no tópico a seguir.

\subsection{LENOCÍNIO E TRÁFICO DE PESSOAS}

Neste estudo, interessa especialmente a tipificação dos delitos referentes ao lenocínio, em razão de sua relação com a prostituição, o consentimento e o tráfico de pessoas.

O termo lenocinium ${ }^{44}$ foi empregado pelos romanos na lex Julia de adulteriis coercendis (século I a.C.). Essa lei punia o marido que tirasse proveito do adultério praticado pela própria esposa ou que não repudiasse a adúltera pega em flagrante. $\mathrm{O}$ lenocínio ligado à prostituição começou a ser punido em Roma a partir do advento do Cristianismo ${ }^{45}$.

Na Idade Média o lenocínio também era punido, inclusive com a pena capital, especialmente o praticado pelo pai ou marido em relação a seus filhos ou esposa ${ }^{46}$. Galdino Siqueira $^{47}$ afirma que, além dos castigos corporais, da prisão e do banimento, aplicavam-se

\footnotetext{
${ }^{43}$ Nesse sentido: Cezar Roberto Bitencourt, Tratado de direito penal, v. 4, p. 197; Celso Delmanto et. al., Código penal comentado, p. 727; Alessandra Greco e João Daniel Rassi, op. cit., p. 196; e Renato Silveira, op. cit., p. 349.

${ }^{44}$ FRAGOSO, Heleno Cláudio. Lições de direito penal, p. 509.

${ }^{45}$ Idem, p. 509-510.

${ }^{46}$ Idem, p. 510.

${ }^{47}$ SIQUEIRA, Galdino. Direito penal brasileiro, v. 2, p. 491.
} 
também penas de ordem moral com publicidade. O autor menciona a capitular de Carlos Magno, de 802, que obrigava o rufião a carregar nas costas até a praça pública a mulher por ele prostituída.

No Brasil, as Ordenações Filipinas tratavam da matéria nos Títulos XXXII - Dos alcoviteiros, e dos que em suas casas consentem a mulheres fazerem mal de seus corpos e XXXIII - Dos rufiões e mulheres solteiras -, podendo ser aplicada a pena de morte.

O Código Criminal do Império, de 1830, não dispunha sobre a matéria, o que constituiu, nas palavras de Fragoso ${ }^{48}$, “omissão indesculpável”. Já o Código Republicano, de 1890, dispunha sobre o lenocínio em capítulo próprio (arts. 277 e 278).

O Código Penal de 1940, com a redação alterada em 2009, dispõe sobre a matéria no Capítulo V do Título VI - Do lenocínio e do tráfico de pessoa para fim de prostituição ou outra forma de exploração sexual. A redação original, de 1940, era: do lenocínio e do tráfico de mulheres. Nesse capítulo temos tipificados os seguintes delitos ${ }^{49}$ : mediação para servir a lascívia de outrem (art. 227), favorecimento da prostituição ou outra forma de exploração sexual (art. 228), manter estabelecimento em que ocorra exploração sexual (art. 229), rufianismo (art. 230) e tráfico internacional e interno de pessoa para fim de exploração sexual (arts. 231 e 231-A).

Segundo ensina Nélson Hungria ${ }^{50}$, o legislador de 1940 poderia ter optado apenas pelo termo "lenocínio" para designar todo o capítulo, pois tanto o tráfico de mulheres ${ }^{51}$ como o proxenetismo ${ }^{52}$ ou o rufianismo ${ }^{53}$ constituem modalidades de lenocínio.

\footnotetext{
${ }^{48}$ FRAGOSO, op. cit., p. 510.

${ }^{49}$ Utilizamos o nomen juris determinado pelo legislador, com exceção do tipo do art. 229, antigo delito de “casa de prostituição", que, com o advento da Lei n. 12.015, de 2009, restou sem indicação. Nota-se que na denominação do capítulo o legislador utiliza "tráfico de pessoa para fim de prostituição ou outra forma de exploração sexual", porém, no nomen juris do tipo utiliza "tráfico internacional de pessoa para fim de exploração sexual". O mesmo ocorre com o tráfico interno.

${ }^{50}$ HUNGRIA, Nélson. Comentários ao Código Penal, p. 266-267.

${ }^{51}$ Denominação original do Código Penal de 1940, hoje tráfico de pessoa.

${ }^{52}$ Segundo De Plácido e Silva, op. cit., v. III, p. 500, proxenetismo é a qualidade ou profissão do proxeneta. Completa afirmando que o proxeneta é o mediador do comércio carnal, de cujos lucros participa. "É o alcoviteiro por interesse". Difere-se do cáften, pois este é o traficante de mulheres.

${ }^{53}$ Rufianismo, para De Plácido e Silva, op. cit., v. IV, p. 155, "é a exploração comercial da mulher, entregue à luxúria pública". Nesse sentido, o rufião é aquele "que vive ou tira proveito da prostituição alheia".
} 
Lenocínio, para Hungria, é prestar assistência à libidinagem de outrem ou dela tirar proveito. Ao contrário do que ocorre nos demais delitos sexuais, o agente, em vez de servir à própria concupiscência, opera em favor da satisfação da lascívia alheia. Para o autor, proxenetas, rufiões e traficantes de mulheres estão no ponto extremo da escala da indignidade. Em suas palavras, "são moscas da mesma cloaca, vermes da mesma podridão",54.

No mesmo sentido, Heleno Cláudio Fragoso ${ }^{55}$, para quem o lenocínio se insere entre "os mais torpes dos crimes, ofendendo a moral pública e os bons costumes"; e Magalhães Noronha ${ }^{56}$, que entende que se trata de uma ação torpe, atentando contra as "normas do pudor e do decoro, necessárias à vida em comunhão".

Hoje, alguns autores ${ }^{57}$ entendem que, tratando-se de sujeito maior, e em não havendo o abuso e a exploração da prostituição mediante violência, grave ameaça ou qualquer outra situação em que se verifique a violação do consentimento, não há falar em crime.

É pertinente a observação de Cezar Bitencourt ${ }^{58}$, segundo o qual o legislador age contraditoriamente: ao mesmo tempo em que visa proteger a liberdade sexual individual (art. $5^{\circ}$, X e XLI, da Constituição Federal), criminaliza o exercício dessa mesma liberdade.

$\mathrm{Na}$ lição de Alessandra $\mathrm{Greco}^{59}$, em situações nas quais é possível uma autoproteção da vítima, deveria ser excluído o próprio tipo penal, pois não se trataria nem de caso de diminuição da pena, nem de exclusão da culpabilidade. Em casos assim, é tempo de o Estado abandonar o tratamento paternalista que dispensa às vítimas, exigindo desta uma postura mais responsável.

\footnotetext{
${ }^{54}$ HUNGRIA, op. cit., p. 267.

${ }^{55}$ FRAGOSO, op. cit., p. 511.

${ }^{56}$ NORONHA, Edgard Magalhães. Direito penal, p. 212.

${ }^{57}$ Nesse sentido: Cezar Roberto Bitencourt, op. cit, p. 156-157; Guilherme Nucci, op. cit., p. 143; Renato de Mello Jorge Silveira, op. cit., p. 336; Luiz Flávio Gomes, Crimes contra a dignidade sexual e outras reformas penais, disponível em: <http://www.lfg.com.br>. Acesso em: 14 set. 2009.

${ }^{58}$ BITENCOURT, op. cit., p. 156-157.

${ }^{59}$ GRECO, Alessandra Orcesi Pedro. A autocolocação da vítima em risco, p. 45.
} 
No mesmo sentido, Renato Silveira ${ }^{60}$, para quem a maioria dos tipos penais relativos ao lenocínio é exemplo de paternalismo legal, pois limitam aprioristicamente a liberdade quanto à disposição ao sexo, sem dano aparente à pessoa.

Dessa forma, entende-se prejudicada a criminalização dos tipos previstos nos arts. 227, 228, 229 e 230 do Código Penal, na forma estabelecida no caput de cada artigo. Segundo dispõe Rogério Greco ${ }^{61}$, o princípio da intervenção mínima serve de orientação ao legislador quando da criação ou revogação das figuras típicas, e conclui-se que é com base nesse princípio que o legislador deveria observar o capítulo do Código Penal referente ao lenocínio.

$\mathrm{O}$ art. 227 dispõe sobre a mediação para servir à lascívia de outrem, e estabelece pena máxima de 3 anos de reclusão para aquele que induzir alguém a satisfazer a lascívia de outrem. Quando se trata de adultos capazes, esse é um exemplo claro de paternalismo legal, devendo a conduta ser descriminalizada.

$\mathrm{Na}$ mesma vertente, Guilherme $\mathrm{Nucci}^{62}$ entende que mencionado delito é inconstitucional, por ferir os princípios da intervenção mínima e da proporcionalidade. Segundo o autor, várias figuras típicas precisam ser reavaliadas. A conduta pode até ser considerada imoral ou antiética, mas não necessariamente prejudica terceiros. A liberdade individual foi consagrada pela Constituição Federal de 1988, pouco importando ao Estado a maneira como cada pessoa conduz sua vida sexual, desde que não prejudique terceiros ${ }^{63}$.

$\mathrm{O}$ art. 228 dispõe sobre o favorecimento da prostituição ou outra forma de exploração sexual. Esse dispositivo foi alterado pela Lei n. 12.015, de 2009, acrescentando-se a expressão "ou outra forma de exploração sexual” ao seu nomen juris. Como veremos a seguir, ainda não há conceituação aceita pela doutrina ou jurisprudência para exploração sexual, o que dificultará sua aplicação. A pena para tal delito é a reclusão, de 2 a 5 anos, e a multa.

\footnotetext{
${ }^{60}$ SILVEIRA, op. cit., p. 336.

${ }^{61}$ GRECO, Rogério. Direito penal do equilíbrio, p. 62.

${ }^{62}$ NUCCI, op. cit, p. 146.

${ }^{63}$ Idem, p. 139-140.
} 
$\mathrm{O}$ dispositivo em questão apenas poderia justificar-se ${ }^{64}$ no tocante à conduta impedir ou dificultar que alguém abandone a prostituição. Nas demais condutas previstas, induzir ou atrair alguém à prostituição, não há falar em dano ao bem jurídico tutelado na ausência de violência, grave ameaça ou fraude ${ }^{65}$.

Conforme preceitua Guilherme Nucci ${ }^{66}$, “o amparo à prostituição pode ser útil e legítimo, desde que respeite a livre vontade da pessoa que comercializa o sexo". Assim, a suposta imoralidade da conduta não a eleva à categoria de bem jurídico tutelado pelo direito penal. Além disso, se a atividade principal - que é a prostituição - não é ilícita, seria um contrassenso punir aquele que a favorece.

A título ilustrativo, o art. 188, item 1, do Código Penal espanhol pune apenas aquele que "determine, empregando violência, intimidação ou fraude, ou abusando de uma situação de superioridade ou de necessidade ou vulnerabilidade da vítima, a pessoa maior de idade a exercer a prostituição ou a manter-se nela" (tradução nossa). Ou seja, havendo consentimento válido, não há falar em crime, pois o bem jurídico tutelado é a liberdade sexual.

$\mathrm{O}$ art. 229 apena com reclusão de 2 a 5 anos, e multa, aquele que mantiver estabelecimento em que ocorra exploração sexual. Esse delito, cujo nomen juris anteriormente à Lei n. 12.015, de 2009, era casa de prostituição, há muito vem sendo criticado pela doutrina e jurisprudência, pois se trata de conduta absolutamente tolerada.

A mencionada lei substituiu "lugar destinado a encontros para fim libidinoso" por “estabelecimento em que ocorra exploração sexual”. As observações sobre a inexistência da correta conceituação de exploração sexual aplicam-se a esse delito.

$\mathrm{O}$ art. 230 dispõe sobre o rufianismo, que é a conduta praticada por aquele que tira proveito da prostituição alheia, ou se deixa sustentar pela pessoa que a exerce, com pena de reclusão de 1 a 4 anos, e multa. Em que pese ser uma conduta eticamente reprovável para alguns, tratando-se de pessoa maior e capaz que consente com a situação, não há razão para a intervenção do direito penal.

\footnotetext{
${ }^{64}$ SILVEIRA, op. cit., p. 336.

${ }^{65}$ Essas figuras aparecem como qualificadoras do tipo, previstas no art. 228, $\S 2^{\circ}$, do Código Penal.

${ }^{66}$ NUCCI, op. cit., p. 148.
} 
Renato Silveira ${ }^{67}$ chama a atenção para o fato de que ninguém questiona o sujeito que trabalha e se mantém com o dinheiro adquirido por meio de espetáculos ou filmes pornográficos. Embora não se trate da prostituição em sua forma clássica, também se refere à mercancia do sexo.

Segundo Guilherme Nucci ${ }^{68}$, na vida secular existem agentes que fazem intermediações em diversas atividades e recebem comissão por esse trabalho. No caso do rufianismo, a punição não ocorre por se tratar de uma conduta ilícita, mas por ser considerada moralmente condenável.

O princípio da intervenção mínima deve ser respeitado, cabendo ao direito penal tutelar apenas as situações em que de fato haja dano ao bem jurídico. Se a pessoa maior e capaz optar por se prostituir, não se deverá punir aquele que a ajudar, ou se deixar sustentar por ela. Não havendo violência, fraude, engano, exploração de situação de vulnerabilidade, ou se tratando de menor ou incapaz, não cabe ao Estado interferir na esfera privada do cidadão. Não é o direito penal que deve interferir. Este é a ultima ratio. Cabe ao Estado fornecer os meios para que o adulto possa optar por um trabalho, e, se a opção for pela prostituição, pela advocacia, pela medicina ou pela limpeza de bueiros, a escolha deverá ser respeitada.

O delito de tráfico de pessoas para fim de exploração sexual (art. 231) será tratado no capítulo 4 deste trabalho, e a questão da possível descriminalização da figura prevista no caput, no capítulo 7, que dispõe sobre o consentimento.

\subsubsection{Prostituição: proibir, regulamentar ou abolir?}

"A forma remanescente de escravatura feminina representada pela prostituição precisa ser abolida. Não uma abolição nos moldes românticos e líricos da de 13 de maio, que emancipou juridicamente o negro mas o deixou abandonado, escravo da pobreza, da ignorância, do vício, dos preconceitos de toda sorte. Mas uma abolição de fato, que proceda segura e objetivamente, conhecendo as causas reais do fenômeno e atacando-o com segurança e precisão."

\footnotetext{
${ }^{67}$ SILVEIRA, op. cit., p. 337.
}

${ }^{68}$ NUCCI, op. cit., p. 155. 
A epígrafe que abre este item, embora escrita no início dos anos 50 do século passado, poderia ter sido escrita hoje. Considerada imoral e degradante por alguns, e opção de trabalho por outros, a prostituição é tema que nunca será pacífico. Porém, deve-se analisá-la em face dos princípios e garantias de um Estado Social e Democrático de Direito. Um Estado laico.

A prostituição é antiquíssima, sendo difícil precisar seu surgimento. Referida na Bíblia e em outros documentos históricos, já se apresentou sob diversas formas, como a prostituição hospitaleira ou religiosa, sem o sentido infamante ${ }^{69}$ presente na conceituação atual.

Na definição de Cernicchiaro ${ }^{70}$, prostituição é a conduta desregrada de uma pessoa que se entrega à prática de relações sexuais. No mesmo sentido, Bento de Faria ${ }^{71}$ define prostituição como a conduta de quem concede o gozo de seu corpo, em regra habitualmente, a qualquer pessoa. Para ambos o pagamento era prescindível.

Hoje se pode definir prostituição como o modo habitual de vida daquele que se entrega à prática sexual mediante retribuição financeira ${ }^{72}$.

Por todos os continentes há uma diversidade de tratamento dispensado àqueles que exercem a prostituição. De criminosos a profissionais do sexo, o que ainda não se conseguiu afastar foi o preconceito. Em sua maioria mulheres, ainda carregam a pecha de mulheres públicas, de vida fácil, de vida airada, rameiras, zabaneiras, marmitas, inferiores, decaídas, horizontais, desavergonhadas, mundanas, cortesãs, marafonas.

E o preconceito já foi formal, prescrito em lei. No Brasil, desde as Ordenações Filipinas até o advento do Código Penal de $1940^{73}$, as prostitutas foram tratadas de forma

\footnotetext{
${ }^{69}$ FRAGOSO, op. cit., p. 508.

${ }^{70}$ CERNICCHIARO, op. cit., p. 413-414.

${ }^{71}$ FARIA, Bento. Código Penal brasileiro comentado, p. 96.

${ }^{72}$ Segundo lição de Sara Aguado López, a doutrina majoritária na Espanha exige quatro elementos para que se configure a prostituição: entrega sexual (ato sexual em sentido amplo, como os que configuram o estupro - art. 213 do Código Penal brasileiro); preço (contraprestação econômica); promiscuidade (entrega sexual a uma pluralidade de pessoas); e habitualidade (certa reiteração de atos sexuais com distintas pessoas). In: BOIX REIG, Javier (dir.). Derecho penal: parte especial, p. 382.

${ }^{73}$ O Código Penal de 1940 trouxe uma igualdade formal entre as mulheres para o crime de estupro, porém, a postura dos tribunais sempre foi preconceituosa no tocante às prostitutas.
} 
desigual quando vítimas de crimes graves como o estupro. Para ilustrar é possível citar o Código do Império que previa para esse delito a pena de 3 a 12 anos quando a vítima era mulher honesta, e de 1 mês a 2 anos quando prostituta.

Cada país adota para o tratamento da prostituição a política criminal que lhe parece mais conveniente, e para todos eles existem defensores tenazes. Vejam-se a seguir os três sistemas mais comumente utilizados: proibição, regulamentação e abolição.

A proibição é o sistema adotado hoje nos Estados Unidos ${ }^{74}$, por exemplo. Consiste em criminalizar a prostituição de per si, punindo seu exercício e também sua exploração. São conhecidas várias tentativas de proibição da prostituição ao longo da história, especialmente por influência religiosa. Porém, pode-se afirmar que o proibicionismo se encontra falho na origem ${ }^{75}$, já que toda tentativa de proibição foi burlada.

O desrespeito à proibição, a ascensão da burguesia ao poder, bem como o surgimento de inúmeras doenças venéreas, como a sífilis, fez surgir diversas tentativas de regulamentar a prostituição a partir do século XVIII $^{76}$. Surgiu assim o sistema da regulamentação, que teve início em 1803, na França, e se espalhou para outros países. Esse sistema considerava a prostituição um mal necessário ${ }^{77}$, e a cercava de medidas higiênicas e policiais, visando salvaguardar a saúde da população e a ordem pública.

Além dessas medidas, modernamente há a preocupação também com questões fiscais e previdenciárias (direito prostitucional ${ }^{78}$ ). É o sistema adotado atualmente na Holanda e na Alemanha.

\footnotetext{
${ }_{75}^{74}$ Com exceção do estado de Nevada. In: BATSTONE, David. Not for sale, p. 163.

${ }^{75}$ SILVEIRA, op. cit., p. 332.

${ }^{76}$ Idem, p. 328.

${ }^{77}$ Essa visão da prostituição como mal necessário já era vista nos escritos de Santo Agostinho (séc. V): "Aufer meretrices de rebus humanis, turbaveris omnia libidinibus"; e Tomás de Aquino (séc. XIII): "A prostituição é comparável à cloaca de um palácio: removida aquela, torna-se este um lugar fétido e impuro". Séculos depois o entendimento de Nélson Hungria era o mesmo, ao afirmar que, embora a prostituição seja um mal deplorável, "cumpre reconhecer-lhe uma função preventiva na entrosagem da máquina social: é uma válvula de escapamento à pressão de irrecusável instinto, que jamais se apaziguou na fórmula social da monogamia, e reclama satisfação antes mesmo que o homem atinja a idade civil do casamento ou a suficiente aptidão para assumir os encargos da formação de um lar. Anular o meretrício, se isso fora possível, seria inquestionavelmente orientar a imoralidade para o recesso dos lares e referver a libido para a prática de todos os crimes sociais". In: HUNGRIA, op. cit., p. 268.

${ }^{78}$ SILVEIRA, op. cit., p. 333.
} 
No Brasil já houve tentativas de regulamentar a prostituição. Em São Paulo ${ }^{79}$, no ano de 1896, foi publicado o Regulamento Provisório da Polícia de Costumes, assinado pelo chefe de polícia Xavier de Toledo. As recomendações referiam-se à forma de vestir, de se apresentar e de se comportar nas ruas, teatros e divertimentos públicos. Esse regulamento sofreu muitas críticas, entre elas a de regulamentar uma instituição não reconhecida. Nos anos de 1908 e 1913 o assunto voltou a ser lembrado, agora na forma de projeto de lei na Câmara Municipal de São Paulo, pelos vereadores José Oswald e Armando Prado, respectivamente. Os projetos dispunham sobre o registro das prostitutas em órgão competente, bem como sobre medidas higiênicas. Ambos foram rejeitados.

Mais recentemente, o então deputado Fernando Gabeira apresentou o projeto de lei n. $98 / 2003^{80}$, segundo o qual o primeiro passo para a regulamentação da prostituição seria aprovar uma lei dispondo que as prostitutas fazem jus ao pagamento por seu ofício. Além disso, também sugeria a revogação dos arts. 228 (favorecimento da prostituição), 229 (casa de prostituição) e 231 (tráfico de pessoas) do Código Penal. Em 2011 essa proposição foi arquivada. Acredita-se tratar-se de mais um projeto míope, limitado, cujo autor desconhece o problema da prostituição e de crimes graves como o tráfico de pessoas.

Atualmente, no Brasil, o profissional do sexo ${ }^{81}$ está catalogado no item 5198-05 da Classificação Brasileira de Ocupações - CBO, do Ministério do Trabalho e Emprego.

A CBO, instituída pela Portaria n. 397, de 2002, tem por finalidade apenas a identificação das ocupações no mercado de trabalho. A regulamentação da profissão deve ser realizada por meio de lei, mas, ao contrário de outros países, não existe lei no Brasil que regulamente a prostituição.

\footnotetext{
${ }^{79}$ FONSECA, Guido. História da prostituição em São Paulo, p. 168-178.

80 “Art. $1^{\circ}$ É exigível o pagamento pela prestação de serviços de natureza sexual.

$\S 1^{\circ} \mathrm{O}$ pagamento pela prestação de serviços de natureza sexual será devido igualmente pelo tempo em que a pessoa permanecer disponível para tais serviços, quer tenha sido solicitada a prestá-los ou não.

$\S 2^{\circ} \mathrm{O}$ pagamento pela prestação de serviços de natureza sexual somente poderá ser exigido pela pessoa que os tiver prestado ou que tiver permanecido disponível para os prestar.

Art. $2^{\circ}$ Ficam revogados os artigos 228, 229 e 231 do Código Penal.

Art. $3^{\circ}$ Esta lei entra em vigor na data da sua publicação".

${ }^{81}$ Nos termos da CBO (Disponível em: <http://www.mtecbo.gov.br/cbosite/pages/home.jsf>. Acesso em: 17 jan. 2011):

"5198-05 - Profissional do sexo: Garota de programa, Garoto de programa, Meretriz, Messalina, Michê, Mulher da vida, Prostituta, Trabalhador do sexo.

Descrição sumária: Buscam programas sexuais; atendem e acompanham clientes; participam em ações educativas no campo da sexualidade. As atividades são exercidas seguindo normas e procedimentos que minimizam a vulnerabilidades da profissão".
} 
Para Guilherme Nucci, já que se convive com a prostituição, deveria "imperar o bom senso" e disciplinar e regularizar seu exercício, inclusive por meio de intermediários $^{82}$.

Segundo lição de Esther de Figueiredo Ferraz $^{83}$, o regulamentarismo é censurável juridicamente. A autora exemplifica com a realização de exames médicos periódicos pelas prostitutas, e a não necessidade desses mesmos exames pelos clientes. Ou seja, recai exclusivamente sobre a mulher a sanção por um ato que é bilateral. Para a autora, o Estado que regulamenta a prostituição se torna um proxeneta ${ }^{84}$.

Para Nélson Hungria, que defendia a função social da prostituição, a melhor solução para tratá-la seria a liberdade vigiada, ou seja, "o confinamento das meretrizes deixadas à sua própria iniciativa, em locais discretos ou a coberto de maior escândalo" ${ }^{, 85}$. $\mathrm{O}$ autor era contrário à regulamentação oficial, entendendo que esta criava "ambiente propício ao incaroável cativeiro das decaídas e ao proxenetismo parasitário”. Hungria corrobora seu posicionamento ao narrar o episódio ocorrido nas cercanias do canal do Mangue, no Rio de Janeiro, em meados do século XX. Segundo o autor, as prostitutas aglomeravam-se nessa região sem maior escândalo, além de frequentarem o ambulatório antivenéreo do hospital vizinho. Um "chefe de polícia puritano", valendo-se do regime ditatorial vigente, expulsou as meretrizes da região. Em vez de acabar com a prostituição, o que o chefe de polícia conseguiu - segundo as críticas de Hungria - foi fazer com que as prostitutas se infiltrassem nas vizinhanças das famílias honestas da cidade; que houvesse o recrudescimento dos crimes sexuais; além da disseminação dos males venéreos ${ }^{86}$.

No início do século XX, imperava no Brasil o regime de tolerância sobre o funcionamento das casas de prostituição. A polícia e os demais órgãos públicos responsáveis pela moralidade das cidades permitiam seu funcionamento, sujeitos à fiscalização e a algumas regras. Segundo lição de Guido Fonseca ${ }^{87}$, na cidade de São Paulo a Delegacia de Costumes era a responsável por autorizar a abertura de novos prostíbulos, o que exigia uma série de documentos, visando mantê-los longe das escolas, templos e

\footnotetext{
${ }^{82}$ NUCCI, op. cit., p. 143.

${ }^{83}$ FERRAZ, Esther de Figueiredo. Prostituição e criminalidade feminina, p. 44-47.

${ }^{84}$ Idem, p. 18.

${ }^{85}$ HUNGRIA, op. cit., p. 276.

${ }^{86}$ Idem, p. 269-273.

${ }^{87}$ FONSECA, op. cit., p. 164-165.
} 
bairros residenciais. Além disso, o proprietário deveria pagar tributo, sob a denominação de "pensão não familiar".

A arbitrariedade do regulamentarismo criou um ambiente de muitas críticas. Paradigmático foi o trabalho de Josephine Butler ${ }^{88}$, feminista preocupada com o bem-estar das prostitutas, que em 1870 tornou-se líder da Associação Nacional de Senhoras com o fim de revogar o Contagious Diseases Acts (conjunto de leis britânicas sobre a regulamentação da prostituição). Por meio de sua influência, em 1886 o Parlamento inglês revogou essa legislação. A partir daí, outros países também alteraram suas normas, influenciados pelo trabalho de Butler: Suíça, Holanda, Noruega, França e Itália. Foi a primeira onda feminista em torno do tema.

Com a superação desse sistema surgiu a abolição, objetivando abolir os regulamentos de exceção policiais e sanitários que disciplinavam a vida da meretriz. $\mathrm{O}$ escopo desse sistema era submeter a prostituta ao direito comum, como qualquer outra cidadã. De acordo com Esther de Figueiredo Ferraz ${ }^{89}$, o abolicionismo não vê a prostituição como um mal necessário, mas como um mal evitável e reparável. Nesse passo, entendia a professora que a um fenômeno social deveriam aplicar-se armas de natureza social (meios educacionais, assistenciais, entre outros), e não a aviltante regulamentação.

Trata-se de um sistema que pune não a prostituta, mas quem a explora: o rufião, o proxeneta ou o traficante, seja de forma consentida ou não. É o sistema adotado hoje pela política criminal brasileira.

Esther de Figueiredo Ferraz foi uma defensora obstinada do abolicionismo. Para ela a prostituta deveria ser protegida, e as normas jurídicas "não poderiam permanecer insensíveis ante o espetáculo degradante da prostituição" "90. Segundo a autora ${ }^{91}$, no início da década de 50, a prostituição era uma "forma remanescente de escravatura feminina".

\footnotetext{
88 "Josephine Butler was one of the most revolutionary social reformers of the nineteenth century. She challenged the inconsistent and hypocritical standards of her time which unjustly disadvantaged women and she campaigned against the sexual exploitation of vulnerable women and children, working for legislative reform to provide them with some degree of protection, equality and justice". Disponível em: $<$ http://www.josephinebutler.org.uk/>. Acesso em: 20 set. 2011.

${ }^{89}$ FERRAZ, op. cit., p. 68 e 75.

${ }^{90}$ FERRAZ, op. cit., p. 41.

${ }^{91}$ Idem, p. 1.
} 
Naquela década, ainda segundo o entendimento da jurista" ${ }^{92}$ o combate ao meretrício era "a mais legítima e premente das reivindicações feministas".

Para Esther de Figueiredo Ferraz ${ }^{93}$, salvo raras exceções, as causas da prostituição seriam o insuficiente amadurecimento psíquico das menores, as anormalidades físicas ou mentais, a pobreza excessiva, a desorganização do meio familiar, a falta de educação intelectual, moral e profissional e até mesmo a desonra ${ }^{94}$ por um crime sexual sofrido. Hoje se pode afirmar que a maior parte dessas causas persiste, mantidas as exceções e afastada a carga moral.

Gilberto Dimenstein ${ }^{95}$ entrevistou, entre os anos de 1991 e 1992, 53 meninas e adolescentes prostitutas para a investigação jornalística que culminou no livro Meninas da noite. Desse universo, $95 \%$ vinham de famílias desestruturadas; $80 \%$ não tinham contato com o pai; $35 \%$ admitiram que sofreram tentativas de abuso sexual em casa, apontando o padrasto como principal responsável diante de uma mãe passiva; $50 \%$ apontavam a bebida como um problema familiar.

Observam-se, a partir da segunda metade do século passado, algumas mudanças de paradigma no direito penal sexual ocidental, inclusive na seara da prostituição.

Influenciaram tais mudanças alguns estudos e leis esparsas, sendo exemplo o Wolfenden Report, de 1957. Trata-se de relatório fruto de uma comissão de estudos britânica presidida por John Wolfenden, que não considerava a prostituição um fato punível em si $^{96}$, mas recomendava sua incriminação se praticada nas ruas, porque o assédio a cidadãos comuns seria um incômodo ofensivo ${ }^{97}$.

\footnotetext{
${ }^{92}$ FERRAZ, op. cit., p. 3.

${ }^{93}$ Idem, p. 6-7.

${ }^{94}$ Machado de Assis, no conto Virginius: narrativa de um advogado, discorre sobre a importância da honra sexual, mostrando que a sua proteção poderia sobrepor-se até mesmo à proteção do bem jurídico vida.

${ }^{95}$ DIMENSTEIN, Gilberto. Meninas da noite, p. 71. O autor afirma que esses números devem ser encarados com cautela, pois a maioria das entrevistadas tem dificuldade de contar detalhes mais íntimos de sua vida sexual e em família.

${ }^{96}$ SILVEIRA, op. cit., p. 45.

${ }^{97}$ HART, op. cit., p. 41.
} 
Outro exemplo é a Lei Merlin, italiana, de 1958, que versava sobre a abolizione della regolamentazione della prostituzione e lotta contro lo sfruttamento della prostituzione altrui ${ }^{98}$.

Atualmente existem duas situações ${ }^{99}$. De um lado, de cunho feminista, o entendimento de que a prostituição é um tipo de exploração baseada no gênero. Partindo do pressuposto kantiano de que a pessoa é um fim em si mesma, não pode ser tratada nem por si própria - como objeto ou ferramenta, sob pena de violar o princípio da dignidade humana. De outro lado temos a corrente que defende a prostituição como uma forma de trabalho qualquer. Segundo esse entendimento, a dignidade humana pressupõe a autonomia da vontade, e a opção pela prostituição deve ser respeitada.

Nesse sentido, existem dois grandes grupos internacionais, cada um defendendo uma das teses mencionadas, que têm influenciado decisões sobre a prostituição em todo o mundo. Esses grupos tiveram participação decisiva também na elaboração do Protocolo de Palermo. São eles: CATW - Coalition Against Trafficking in Women e GAATW - Global Alliance Against Traffic in Women.

A CATW ${ }^{100}$ é uma organização não governamental de penetração mundial que visa promover os direitos humanos das mulheres contra a indústria do sexo. Para ela, são formas de exploração sexual: prostituição, assédio sexual, estupro, incesto, pornografia, turismo sexual e casamento servil. Segundo o entendimento dessa organização, todo tipo de prostituição explora a mulher, inclusive a consensual.

Díez Ripollés ${ }^{101}$ afirma que essa forma de pensamento feminista, denominada neoabolicionista, coloca em primeiro lugar a defesa do gênero em detrimento da pessoa prostituída. Para essa corrente, mesmo se houvesse prostituição voluntária, esta seria inadmissível tendo em vista a proteção do gênero.

Entende-se que tal postura é excessivamente paternalista, não oferecendo à mulher a prerrogativa da escolha. O bem jurídico tutelado nos delitos sexuais é individual, e não

\footnotetext{
${ }^{98}$ SILVEIRA, op. cit., p. 46.

${ }^{99}$ Idem, 343-344.

$100<$ http://catwinternational.org/>.

${ }^{101}$ DÍEZ RIPOLLÉS, op. cit., p. 95-96.
} 
coletivo. O próprio Tribunal de Justiça da Comunidade Europeia ${ }^{102}$ decidiu que o exercício autônomo e voluntário da prostituição é uma atividade econômica como qualquer outra.

Já a GAATW ${ }^{103}$, de cunho mais liberal, visa o respeito aos direitos humanos de todas as mulheres, inclusive a liberdade de decidir no que vão trabalhar. Constituindo uma rede de cerca de 90 organizações não governamentais de todas as regiões do mundo, inclusive do Brasil, a GAATW se empenha em promover mudanças nos sistemas político, econômico, social e legal e também qualquer estrutura que contribua para a manutenção do tráfico de pessoas e outras violações dos direitos humanos no contexto dos movimentos migratórios.

O tratamento do tema em alguns países europeus é emblemático, seja pelo caráter mais liberal ou mais radical. Como exemplo de países liberais é possível citar a Holanda e a Alemanha, que regulamentaram a prostituição em 2000 e 2002, respectivamente, considerando-a mais uma profissão. De outro lado aparecem os nórdicos, que não proibiram a prostituição, mas sim a compra de serviços sexuais. Em 1999 a Suécia adotou essa postura, seguida pela Finlândia em 2004, pela Noruega e pela Islândia em 2009.

A CATW ${ }^{104}$ noticia que, nos países onde foi regulamentada, a prostituição só aumenta. Já nos países onde o cliente é punido ela diminuiu, bem como todas as suas formas de exploração.

A legislação da Suécia, que vai ao encontro da opinião da maioria de sua população $^{105}$, é baseada na política da igualdade entre os gêneros, dispondo que todas as mulheres devem ter controle total sobre seus corpos. A legislação pretende punir não somente os proxenetas e traficantes, mas também o "cliente", visto como o principal culpado pela prostituição e pelo tráfico de mulheres para essa finalidade.

\footnotetext{
${ }^{102}$ Case C-268/99, Aldona Malgorzata Jany and Others versus Staatssecretaris van Justitie. Disponível em: $<$ http://eur-lex.europa.eu/LexUriServ/LexUriServ.do?uri=CELEX:61999J0268:EN:HTML\#SM>. Acesso em: 26 set. 2011.

$103<$ http://www.gaatw.org/>.

${ }^{104}$ RAYMOND, Janice. Trafficking, prostitution and the sex industry: the Nordic legal model. jul. 2010. Disponível em: $<$ http://action.web.ca/home/catw/readingroom.shtml?x=130078\&AA_EX_Session=d29d9c2ba7f2b721cf12e 01 bacf933ea>. Acesso em: 23 nov. 2011.

${ }^{105}$ Segundo Janice Raymont, op. cit., mais de $70 \%$ da população aprova esse modelo.
} 
Consoante dados de 2004 trazidos pela então Ministra Gunilla Ekberg ${ }^{106}$, após cinco anos de vigência da norma, a prostituição de rua diminuiu no País todo, e a maioria dos clientes desapareceu. O número de mulheres traficadas para a Suécia não aumentou, pois os traficantes preferem levá-las para outros países, como Holanda, Alemanha e Espanha, onde o clima é mais amigável.

Países como Alemanha e Holanda vêm sendo criticados pela mídia e por organizações como a CATW, pois os resultados da regulamentação da prostituição não são satisfatórios. O objetivo principal da legislação dessas nações era criar políticas públicas que proporcionassem condições de saúde, bem-estar e de previdência para os profissionais do sexo.

Segundo Janice Raymond ${ }^{107}$, da CATW, baseada em dados do próprio governo alemão, o Prostitutiongesetz - ProstG (Lei alemã sobre prostituição, ou German Prostitute Act) não foi capaz de melhorar as condições de vida das prostitutas, não as ajudou a deixar a prostituição, e também não reduziu a criminalidade nesse ambiente. A mesma situação insatisfatória se dá hoje na Holanda, onde a ideia do governo de ver a prostituição apenas como mais um "negócio" tornou-se uma ilusão ${ }^{108}$.

David Batstone ${ }^{109}$, do movimento Not for Sale, afirma que os modelos alemão e holandês geraram um mercado negro de estrangeiras às quais não se aplica a legislação protecionista desses países. No ano de 2003 eram 65\% de estrangeiras no mercado do sexo na Holanda e $50 \%$ na Alemanha.

\footnotetext{
${ }^{106}$ EKBERG, Gunilla. The Swedish law that prohibits the purchase of sexual services: best practices for prevention of prostitution and trafficking in human beings. Violence against women. v. 10. out. 2004. Disponível em: <http://action.web.ca/home/catw/attach/Ekberg.pdf>. Acesso em: 28 nov. 2010.

${ }^{107}$ RAYMOND, Janice. Trafficking, prostitution and the sex industry: the Nordic legal model. jul. 2010. Disponível em:

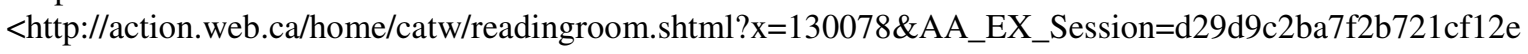
01bacf933ea>. Acesso em: 23 nov. 2011.

${ }^{108}$ Apenas para ilustrar, sem cunho científico, em reportagem da Revista Veja afirma-se que como efeito colateral da legalização da prostituição na Holanda houve a explosão no número de bordéis e o aumento na demanda por prostitutas. Com o aumento de $260 \%$ no tráfico de mulheres nos três primeiros anos da legalização, houve uma invasão de prostitutas de regiões mais pobres, como África, América Latina e Leste Europeu. In: FAVARO, Thomas. Mudanças na vitrine. Revista Veja, edição 2050, 5 mar. 2008. Disponível em: <http://veja.abril.com.br/050308/p_098.shtml>. Acesso em: 10 mar. 2011.
}

${ }^{109}$ BATSTONE, op. cit., p. 164. 
Embora festejado por aqueles que veem a prostituição como mais uma forma de exploração sexual, o modelo sueco recebe duras críticas, atribuindo-se a sua legislação um caráter meramente simbólico. Para Renato Silveira ${ }^{110}$, essa espécie de terceira via no trato da prostituição peca principalmente pela perspectiva de contenção da denominada exploração da venda de sexo. Esse autor acredita que a criminalização nunca se mostrou como instrumento adequado para tal tipo de controle social, controle esse carregado de carga moral.

O Estado Democrático de Direito garante a todos o direito à liberdade. Assim, quando diante de um consentimento válido, que não esteja eivado de qualquer tipo de vício, e não se tratando de pessoa vulnerável, entende-se que a opção laboral pela prostituição deve ser respeitada.

O que se pode concluir é que o direito penal não é suficiente para resolver tal questão. Apenas o investimento em políticas sociais, tão arduamente defendidas por Esther de Figueiredo Ferraz, daria outra opção viável a homens e mulheres que se dedicam à prostituição.

\subsubsection{Exploração Sexual}

A Lei n. 12.015, de 2009, acrescentou a expressão exploração sexual ao capítulo que dispõe sobre o lenocínio, ficando assim a redação: "Do lenocínio e do tráfico de

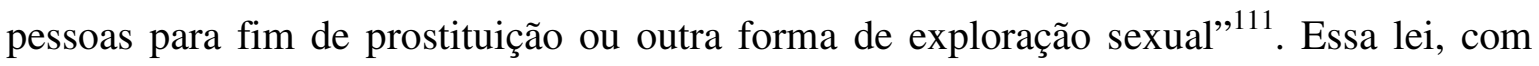
intuito explicativo, também acrescentou o art. 234-C ao Código Penal brasileiro ${ }^{112}$, dispondo que ocorreria exploração sexual em todos os delitos tipificados como crimes contra a dignidade sexual. Contudo, esse dispositivo sofreu veto presidencial.

\footnotetext{
${ }^{110}$ SILVEIRA, op. cit., p. 332-333.

${ }^{111}$ Capítulo V do Título VI do Código Penal.

112 O art. 234-C foi acrescentado pela Lei n. 12.015, de 2009, e dispunha: "Art. 234-C. Para os fins deste Título, ocorre exploração sexual sempre que alguém é vítima dos crimes nele tipificados”.
} 
Segundo a Mensagem de veto ${ }^{113}$, o dispositivo confundia os conceitos de violência sexual e exploração sexual, uma vez que pode haver violência sem a exploração, e viceversa.

A expressão exploração sexual constitui elemento normativo do tipo penal. Segundo Francisco de Assis Toledo ${ }^{114}$ os elementos normativos são os constituídos por termos ou expressões que só adquirem sentido quando completados por um juízo de valor, preexistente em outras normas jurídicas ou ético-sociais ou emitido pelo próprio intérprete. Como não há definição legal, esta ficará a cargo dos doutrinadores e também do Poder Judiciário $^{115}$.

Segundo André Estefam ${ }^{116}$, nosso Código Penal fornece algumas diretrizes na determinação do conceito da elementar. Para o autor, os conceitos de violência sexual (p. ex.: estupro) e de satisfação sexual (atividade lícita) representam os limites interpretativos da exploração sexual. Estefam define exploração sexual como a conduta daquele que tira proveito de outrem, transformando-o em objeto ou mercadoria e promovendo sua degradação sob o aspecto da sexualidade.

Para Guilherme Nucci ${ }^{117}$, a exploração sexual deve ser caracterizada como forma de retirada de vantagem em relação a alguém, valendo-se de fraude, ardil, posição de superioridade ou qualquer outra forma de opressão. Esse autor afirma que a exploração sexual não se confunde com qualquer forma de violência sexual ou com a mera satisfação sexual. No mesmo sentido, Luiz Flávio Gomes ${ }^{118}$ entende que a exploração sexual tem a conotação negativa de aproveitamento ou fruição de uma debilidade.

\footnotetext{
${ }^{113}$ Mensagem n. 640, de 7-8-2009: “Ao prever que ocorrerá exploração sexual sempre que alguém for vítima dos crimes contra os costumes, o dispositivo confunde os conceitos de 'violência sexual' e de 'exploração sexual', uma vez que pode haver violência sem a exploração. Diante disso, o dispositivo estabelece modalidade de punição que se aplica independentemente de verificada a efetiva prática de atos de exploração sexual".

${ }_{114}$ TOLEDO, op. cit., p. 154.

${ }^{115}$ Adriana Piscitelli afirma que a falta de uma definição clara do que seja exploração, tanto pelo Código Penal, como pelo Protocolo de Palermo, dificulta a produção de conhecimento e um eficiente enfrentamento ao tráfico de pessoas. In: PISCITELLI, Adriana. Entre as "máfias" e a "ajuda": a construção de conhecimento sobre tráfico de pessoas. Cadernos Pagu, n. 31, p. 58.

${ }^{116}$ ESTEFAM, André. Crimes sexuais, p. 165.

${ }^{117}$ NUCCI, op. cit., p. 144.

118 GOMES, Luiz Flávio. Crimes contra a dignidade sexual e outras reformas penais, disponível em: <http://www.lfg.com.br>. Acesso em: 14 set. 2009.
} 
Segundo Renato Fabbrini ${ }^{119}$, o termo exploração sexual comporta diferentes acepções no contexto legal, como tirar proveito, beneficiar-se, extrair lucro de uma situação ou de alguém. Para esse autor o fim econômico não é exigido pelo legislador, podendo o proveito ser de natureza sexual, por exemplo.

A definição de exploração sexual do Instituto Interamericano del Niño, la Niña y Adolescentes - IIN ${ }^{120}$ tornou-se uma referência ${ }^{121}$.

Segundo o IIN, a exploração sexual comercial é considerada a atividade econômica que submete a pessoa à industria do sexo, nos âmbitos nacional e internacional. Inclui a prostituição $^{122}$, a produção industrial pornográfica, o turismo sexual, o tráfico de pessoas para fins sexuais $^{123}$, e, mais recentemente, também o sexo e a pornografia via Internet.

O IIN elaborou essa definição visando os menores, porque a prostituição, a pornografia, o tráfico de pessoas e o turismo sexual que os envolvem são sempre abusivos e devem subsumir-se como formas de exploração. O mesmo não ocorre quando essas modalidades envolvem maiores. Nesse caso, o consentimento válido do maior capaz deverá ser considerado.

O caso mais emblemático é o da indústria pornográfica. Filmes, livros e revistas pornográficos são comercializados normalmente, nos termos do art. $5^{\circ}, \mathrm{IX}^{124}$, da Constituição Federal brasileira. Atores e atrizes são remunerados como em um emprego qualquer, e o Estado recolhe tributos dos filmes e revistas, por exemplo. Sendo maiores, e consentindo no ofício, não se pode dizer que se trata de exploração ${ }^{125}$.

\footnotetext{
${ }^{119}$ MIRABETE, Júlio Fabbrini; FABBRINI, Renato N. Código Penal interpretado, p. 1419.

${ }^{120}$ La protección de los derechos de los niños, niñas y adolescentes frente a la violencia sexual, p. 21-22. Disponível em: <http://www.iin.oea.org/IIN2011/materiales-publicaciones.shtml>. Acesso em: 23 nov. 2011. ${ }^{121}$ Rogério Greco adota esta definição: "[...] a prostituição é uma modalidade de exploração sexual. Esta seria o gênero, sendo aquela uma de suas espécies, ao lado do turismo sexual, da pornografia e do tráfico para fins sexuais". In: Curso de direito penal, v. III, p. 591-592.

${ }^{122}$ Sobre prostituição, vide o item 1.4.1.

${ }^{123}$ Sobre tráfico de pessoas, vide o capítulo 4.

124 "IX - é livre a expressão da atividade intelectual, artística, científica e de comunicação, independentemente de censura ou licença;".

125 No mesmo sentido, Guilherme Nucci, op. cit., p. 143, afirma que por si só a pornografia não representa nenhum tipo de exploração. Segundo o autor, a pornografia pode se inserir no contexto da arte e da liberdade de expressão.
} 
Segundo o entendimento feminista, a pornografia é mais uma espécie de discriminação de gênero, ou seja, mais uma forma de expor a mulher subjugada pelo homem, baseada na estrutura de poder macho-fêmea ${ }^{126}$. Renato Silveira critica essa postura, afirmando que não há justificativa para uma censura prévia a qualquer forma de construção comunicacional consentida. Para esse autor, punir-se-iam os efeitos de uma desigualdade já posta, e não suas causas, que são sociais. E não é a isso que se destina o direito penal, sob pena de mostrar-se ingenuamente simbólico ${ }^{127}$.

O turismo sexual ${ }^{128}$ pode ser entendido como aquele que visa a satisfação sexual do turista no país de destino, estando intimamente ligado à prostituição. A regra são turistas procedentes de países desenvolvidos se dirigirem a países pobres ou subdesenvolvidos. Esse tipo de turismo envolve a cumplicidade, por ação direta ou omissão, de órgãos do governo, da polícia, de agências de viagem, hotéis, bares, restaurantes, boates, barracas de praia, taxistas etc.

Os turistas podem vir em grupos ou sozinhos, e muitas vezes o pacote inclui os serviços sexuais a serem prestados. O turismo sexual pode se configurar também nos casos em que a pessoa não comprou o pacote, mas aceita as ofertas feitas pela indústria do sexo no local de destino.

O Código Penal brasileiro relaciona diretamente a exploração sexual com a prostituição. Quando o legislador redige a norma dispondo sobre a "prostituição ou outra forma de exploração sexual", o que se infere, numa interpretação literal, é que a prostituição é mais uma forma de exploração. O mesmo se dá com o Protocolo de Palermo, onde se lê "a exploração da prostituição de outrem ou outras formas de exploração sexual" $\left(\right.$ art. $\left.3^{\circ}, a\right)$.

Guilherme Nucci ${ }^{129}$ entende que a prostituição voluntária não é forma de exploração sexual, podendo ser considerada uma profissão como outra qualquer. Para o

\footnotetext{
${ }^{126}$ SILVEIRA, op. cit., p. 350.

127 Idem, p. 351.

${ }^{128}$ O documentário Cinderelas, lobos e um príncipe encantado, e o Relatório Final da Comissão Parlamentar Mista de Inquérito, tratam deste assunto.

${ }^{129}$ NUCCI, op. cit., p. 143.
} 
autor $^{130}$, só haverá exploração quando presente a fraude, o ardil, a posição de superioridade ou qualquer outra espécie de opressão.

André Estefam ${ }^{131}$ discorda desse posicionamento ao afirmar que não se pode considerar existente a exploração sexual somente quando há fraude ou engodo no proceder do agente.

Segundo Renato Fabbrini ${ }^{132}$, o Código Penal considera a prostituição contrária à dignidade sexual, por isso incrimina as condutas tendentes a favorecer o ingresso ou a permanência nesse estado, independentemente de qualquer condição desvantajosa para a pessoa, mesmo quando esta é maior e capaz.

A prostituição é o modo habitual de vida daquele que se entrega à prática sexual mediante retribuição financeira. Quando a prostituição é voluntária, sendo o consentimento válido, entendemos que fica excluída a exploração. Aqui novamente se afirma que não cabe ao Estado intervir na esfera privada da pessoa plenamente capaz. Contudo, tratandose de menor, pessoa vulnerável, ou presentes a fraude, coação ou violência, fica evidenciada a exploração.

\footnotetext{
${ }^{130}$ NUCCI, op. cit, p. 144.

${ }^{131}$ ESTEFAM, op. cit., p. 165.

${ }^{132}$ MIRABETE e FABBRINI, op. cit., p. 1.420.
} 


\section{O TRÁFICO INTERNACIONAL DE PESSOAS PARA FIM DE EXPLORAÇÃO SEXUAL: EVOLUÇÃO HISTÓRICA}

O tráfico internacional de pessoas para fins sexuais nos moldes como o conhecemos hoje é recente. Porém, a análise histórica mostra que desde os tempos de Colônia o Brasil padece desse mal. Dos séculos XVI a XIX as escravas negras foram obrigadas a se prostituir pelos seus senhores. Finda a escravidão negra, os fluxos migratórios trouxeram ao País as escravas brancas para serem exploradas sexualmente. Hoje, de local de destino, o Brasil tornou-se primordialmente exportador de escravos sexuais.

Vejamos, a seguir, como se deu essa evolução (ou involução) história.

\subsection{TRÁFICO DE ESCRAVOS NEGROS}

A escravidão é bem mais antiga que o tráfico de negros. Ela surgiu nos primórdios da história, quando os povos vencidos eram escravizados por seus conquistadores, o que também acontecia com algumas espécies de criminosos ou com aqueles que não podiam honrar suas dívidas.

Muitas civilizações usaram o trabalho escravo e dependeram dele para a execução de tarefas de toda sorte. As grandes civilizações antigas, como Egito, Grécia e Roma, são exemplos desse modelo.

Embora se faça referência ao tráfico de pessoas como forma moderna de trabalho escravo ou escravidão contemporânea, existe uma diferença primordial entre o tráfico de pessoas que ocorre nos dias de hoje e o tráfico negreiro dos séculos XVI a XIX no Brasil: este último não era ilegal $^{133}$.

\footnotetext{
${ }^{133}$ A Constituição do Império, de 1824, não considerava os escravos cidadãos brasileiros, apenas os libertos e os ingênuos. O Código Criminal do Império, de 1830, trazia disposições específicas sobre os escravos. O Código autorizava os senhores a castigar moderadamente seus escravos (art. 14, § $6^{\circ}$ ), mas proibia açoitá-los com mais de cinquenta chibatadas por dia (art. 60). Havia ainda o delito de insurreição, que consistia em retinirem-se vinte ou mais escravos para buscar a liberdade por meio da força. Os escravos considerados líderes eram punidos com a pena de morte (art. 113). Aquele que ajudasse, excitasse ou aconselhasse escravos a insurgir-se, fornecendo-lhes armas, munições ou outros meios para o mesmo fim, seriam punidos com prisão de até vinte anos, com trabalhos forçados (art. 115).
} 
A escravidão negra, de natureza étnica ou racial, integrava o sistema produtivo da época, e o senhor exercia, licitamente, direito de propriedade sobre o escravo. Ter escravos era sinal de status e poder, mesmo porque consistia em um alto investimento.

Quando se fala em tráfico de negros, a referência é sempre o trabalho forçado, seja doméstico, seja na agricultura, ou outra forma de esforço braçal. Neste tópico serão analisadas as questões atinentes à prostituição e à exploração sexual das escravas.

A violação sexual das negras se dava especialmente por parte dos senhores, mas ocorria também nas senzalas. Um caso emblemático, analisado por Janaína Paschoal ${ }^{134}$, é o da escrava Honorata. Embora comprovadamente estuprada por seu senhor quando tinha cerca de 12 anos de idade, não houve por parte do Poder Judiciário qualquer tipo de punição. O juiz da primeira instância pronunciou o acusado, porém a Relação de Pernambuco, com o voto do Desembargador Freitas Henriques, anulou o feito ab initio, alegando desde questões formais, como a proibição de a escrava dar seu depoimento em juízo sem ser representada pelo senhor, até a razão absurda de que não poderia haver crime de estupro contra uma escrava, uma vez que o tipo penal exigiria duas pessoas livres. Conforme leciona Paschoal, trata-se de mais um caso de interpretação viciada da legislação penal e processual vigente à época.

Gilberto Freyre ${ }^{135}$ apresenta alguns aspectos da prostituição das escravas. Havia os senhores que enfeitavam as negras com joias de ouro, rendas e roupas finas e as ofereciam aos clientes. Outros obrigavam as negras, muitas delas ainda crianças, a se oferecer nas ruas e nos portos, onde desembarcavam marinheiros com toda espécie de moléstia, sobretudo a sífilis. Havia ainda as que ficavam expostas nas janelas, seminuas, nas zonas de meretrício. Comum a todas elas era que a receita dos serviços prestados pertencia aos senhores. Alguns tiravam a própria subsistência desse mercado. Outros o tinham como mais uma fonte de renda.

\footnotetext{
${ }^{134}$ PASCHOAL, Janaína Conceição. A escravidão e a interpretação viciada da lei. Revista do Curso de Mestrado em Direito da Faculdades Integradas Toledo, n. 1, v. 4, p. 71-72.

${ }^{135}$ FREYRE, Gilberto. Casa-grande \& senzala, p. 537-538.
} 
A existência de escravas prostitutas era prática comum no Rio de Janeiro do século XIX. Segundo relata Cristiana Schettini Pereira ${ }^{136}$, os "senhores" dessas escravas eram, em regra, mulheres brasileiras e portuguesas sem muitos recursos ${ }^{137}$.

Sobre a prostituição de escravas em São Paulo não há documento oficial ${ }^{138}$, mas alguns indícios, como anúncios de jornais sobre a venda de belas jovens negras, levam a crer que ela ocorria também nesse Estado ${ }^{139}$.

Conforme afirma Jacob Gorender ${ }^{140}$, a prostituição das escravas era uma prática comum no Brasil. Com a expansão do sistema escravista, houve também o aumento da exploração de negras como prostitutas.

Em $O$ abolicionista, Joaquim Nabuco traça um panorama da escravidão no ano de 1883. No tocante à prostituição, o livro afirma que os senhores empregavam suas escravas em tal ofício, recebendo os lucros do negócio, sem que isso lhes fizesse perder a propriedade sobre elas.

Nesse cenário, a partir do século XIX, advogados abolicionistas propunham Ações de Liberdade em favor de escravas para coibir essa prática. $\mathrm{O}$ argumento, baseado no direito romano, era o de que, por mais amplo que fosse o direito do senhor à propriedade, este não poderia vir a constituir ofensa à lei e ao costume. Ou seja, forçar escravas à prostituição justificava a perda da propriedade.

Podemos citar também o delegado Miguel Tavares ${ }^{141}$, que, em 1870, embora não fosse abolicionista, utilizou o mesmo argumento, visando moralizar a sociedade. Ele

\footnotetext{
136 PEREIRA, Cristiana Schettini. Lavar, passar e receber visitas: debates sobre a regulamentação da prostituição e experiências de trabalho sexual em Buenos Aires e no Rio de Janeiro, fim do século XIX. Cadernos Pagu, n. 25, p. 43.

${ }^{137}$ Sobre o assunto, assim se manifesta Gilberto Freyre, op. cit., p. 237: "Mas, admitida uma exceção ou outra, não foram senhoras de família, mas brancas desclassificadas, que assim exploraram as escravas".

${ }^{138}$ FONSECA, Guido. História da prostituição em São Paulo, 121-124.

${ }^{139}$ No entendimento de Guido Fonseca, op. cit., p. 124-125, a prova mais contundente de que havia escravas negras se prostituindo em São Paulo foi o romance Rosaura, a enjeitada, de Bernardo Guimarães. No capítulo XIII dessa obra, o autor traça com riqueza de detalhes um prostíbulo de escravas negras que eram exploradas pela proprietária, na periferia da capital paulista.

${ }^{140}$ GORENDER, Jacob. O escravismo colonial, p. 500-502.

${ }^{141}$ PEREIRA, op. cit., p. 42-43.
} 
iniciou cerca de duzentas ações de liberdade em favor de escravas prostitutas do centro do Rio de Janeiro ${ }^{142}$.

Guido Fonseca dispõe sobre dois processos que ilustram bem as posições antagônicas relativas à questão. O primeiro deles refere-se a uma ação proposta por duas escravas, Sabina e Salustiana, obrigadas a se prostituir por sua senhora, Custódia Maria de Araújo. $\mathrm{Na} 1^{\mathrm{a}}$ instância venceram, mas na $2^{\mathrm{a}}$ instância foram consideradas carecedoras $d a$ ação. Leia-se a seguir um trecho da sentença e do acórdão:

O que tudo visto e bem meditado, salta aos olhos que, não tendo a nossa legislação dito cousa alguma sobre a prostituição forçada das escravas, e não se devendo crer que assim procedeu o legislador brasileiro, por entender que era ela permitida, deixou que entre nós vigorasse como Direito subsidiário o Romano, que é a respeito, expresso e salutar. E passando do direito ao fato, encontra-se nos autos plena prova de que as Autoras foram forçadas à prostituição e que disso auferia lucros a Ré, que se não livra da imputação e responsabilidade simplesmente por dizer que não lhes infringia castigos corporais, certo como é, que para os escravos constitui coação a ordem do senhor, a quem estão sujeitos sob pena de sofrerem a sua severidade e maus tratos. [...] julgo provada a intenção das Autoras, e condeno a Ré nas custas; declarando, como declaro, aquelas livres pela presente sentença que lhes servirá de título. Rio, 4 de julho de 1872. Joaquim Francisco de Faria (grifos nossos)

Acórdão da Relação. Que reformam a sentença de fls. 59 e julgam as Autoras apeladas carecedoras da ação como escravas que são da Apelante, por não terem aplicação entre nós as disposições indicadas do Direito Romano, como contrário ao direito de propriedade. $[. . .]^{143}$ (grifos nossos)

O outro processo foi decidido no mesmo sentido. Nos termos do Acórdão da Relação, de 20 de agosto de 1872: “[...] quando tivesse ciência ou consentisse não seria motivo justo e menos legal para privá-lo de sua propriedade, galardoando-se a desregrada. [...] mandam que a apelada seja restituída ao apelante, seu legítimo senhor"144.

Miguel Reale Júnior ${ }^{145}$ relata que, em cerca de 1.600 Ações de Liberdade propostas, 729 escravas obtiveram a alforria por serem constrangidas pelos senhores a se prostituir.

\footnotetext{
142 Sobre a questão, Joaquim Nabuco se manifestou da seguinte forma: "nas nossas cidades há casas de comissões abertas, mercados e verdadeiros lupanares, sem que a polícia tenha olhos para essa mácula asquerosa; ainda está recente na memória pública a oposição corajosa de um delegado de polícia da cidade do Rio ao tráfico de escravas para a prostituição" ( $O$ abolicionismo, p. 16-17),

${ }^{143}$ FONSECA, op. cit., p. 120-122.

${ }^{144}$ Idem, p. 122.

${ }^{145}$ REALE JÚNIOR, Miguel. O escravo como não sujeito de direitos. (no prelo)
} 
Mesmo após abolida a escravidão, era possível encontrar ex-escravas negras na prostituição $^{146}$. Aos poucos, porém, foram sendo substituídas pelas europeias, escravas de outros senhores, os cáftens e proxenetas, como se verá no tópico a seguir.

Em que pese não fosse a prostituição o intuito primeiro do tráfico de negros, aqui chegando muitas negras foram exploradas sexualmente por seus senhores e também obrigadas a se prostituir. Segundo Gilberto Freyre ${ }^{147}$, "foram os corpos das negras - às vezes meninas de dez anos - que constituíram, na arquitetura moral do patriarcalismo brasileiro, o bloco formidável que defendeu dos ataques e afoitezas dos don-juans a virtude das senhoras brancas".

Passado mais de um século da abolição da escravatura pela Lei Áurea (1888), poder-se-ia esperar uma evolução social capaz de superar essas atrocidades. Formalmente isso aconteceu. No Brasil, o Decreto n. 58.563, de $1^{\circ}-6-1966$, promulgou a Convenção sobre Escravatura, de 1926, emendada pelo Protocolo de 1953, e a Convenção Suplementar sobre a Abolição da Escravatura, de 1956. Seu art. $2^{\circ}$ determina que os Estados signatários se comprometam a impedir e a reprimir o tráfico de escravos e a promover a abolição completa da escravidão sob todas as suas formas. A Declaração Universal dos Direitos Humanos, de 1948, estabelece em seu art. $4^{\circ}$ que ninguém será mantido em escravidão ou servidão, e que a escravidão e o tráfico de escravos serão proibidos em todas as suas formas. O Pacto de São José da Costa Rica, de 1969, também trata da matéria. $\mathrm{O}$ art. $6^{\circ}$ proíbe a escravidão e a servidão, bem como o tráfico de escravos e o tráfico de mulheres.

Na prática não é o que se vê. No século XXI os seres humanos continuam a ser traficados, escravizados e explorados sexualmente.

\footnotetext{
${ }^{146}$ PEREIRA, op. cit., p. 53.

${ }^{147}$ FREYRE, op. cit., p. 538.
} 


\subsection{DO TRÁFICO DE ESCRAVAS BRANCAS AO TRÁFICO DE PESSOAS}

A partir do final do século XIX, já abolida a escravidão de negros, a preocupação passa a ser com o tráfico de escravas brancas ${ }^{148}$ para fim de exploração sexual. No Brasil, o Código Criminal do Império não previa o crime de lenocínio, mas este foi incluído no Código Penal de 1890, período de intensa migração.

Segundo explica Lená Medeiros de Menezes ${ }^{149}$, a exploração sexual de mulheres não era uma atividade nova durante o século XIX e início do século XX, mas havia adquirido uma nova caracterização "à medida que o capitalismo e a expansão europeia haviam redesenhado o mundo e a vida urbana, promovendo a internacionalização dos mercados e a expansão dos prazeres”. Nesse cenário, a mulher transformou-se em produto de exportação da Europa para outros continentes.

Das últimas décadas do século XIX às primeiras décadas do século XX, Buenos Aires e Rio de Janeiro foram as capitais do tráfico internacional de mulheres na América do Sul e constituíam a porta de entrada para as demais cidades do continente.

Na capital portenha o exercício da prostituição foi regulamentado a partir de 1875, com base em argumentos higiênicos e morais. A inspiração ${ }^{150}$ foi o modelo francês de regulamentação, que definia regras para a circulação das prostitutas, para as condições de trabalho e de moradia, e também exames médicos periódicos e obrigatórios. No Brasil esse modelo nunca foi formalmente aprovado, vigorando o regime da tolerância.

As mulheres eram aliciadas ${ }^{151}$ das mais diversas maneiras, assim como acontece hoje. Certos traficantes se casavam com as vítimas, e chegavam aqui como verdadeiros casais. Algumas mulheres chegavam sozinhas, e outras vinham como integrantes de companhias artísticas.

\footnotetext{
${ }^{148}$ Bento de Faria critica essa denominação, pois às mulheres brancas somam-se as amarelas ou negras. In: Código Penal brasileiro comentado, p. 107.

${ }^{149}$ MENEZES, Lená Medeiros de. O tráfico internacional de mulheres no debut e fin-de-siecle. In: Discursos sediciosos - crime, direito e sociedade, p. 172.

${ }^{150}$ PEREIRA, op. cit., p. 32.

${ }^{151}$ HUNGRIA, Comentários ao Código Penal, v. VIII., p. 293-294; FONSECA, op. cit., p. 136.
} 
Essas mulheres chegavam ao País sem conhecer ninguém e sem entender o idioma, o que as tornava presa fácil da exploração sexual. Muitas delas assinavam contratos com seus exploradores ${ }^{152}$, contratos esses elaborados de tal forma que elas se viam devedoras pelo resto da vida, como ocorre hoje, na chamada escravidão por dívida, muito comum nos rincões do Brasil.

A presença marcante de estrangeiras na prostituição é demonstrada pelos levantamentos feitos por Guido Fonseca ${ }^{153}$ em São Paulo. Segundo esse autor, no ano de 1914 a polícia registrou 812 prostitutas no Estado. Desse montante, 721 eram brancas, 60 pardas e 31 negras, sendo apenas 303 brasileiras. Das estrangeiras, a maior parte vinha da Rússia, Itália, Alemanha e França. A Primeira Guerra Mundial prejudicou o incremento do número de estrangeiras. Tanto que em 1915 a polícia abriu apenas 269 novos prontuários de prostitutas, sendo 181 brasileiras e 88 estrangeiras.

Em 1922 existiam 3.529 prostitutas cadastradas em São Paulo. Dessas, 1.936 eram brasileiras e 1.593 estrangeiras. As estrangeiras vinham especialmente da Rússia (468), da França (255), da Itália (245), de Portugal (155) e da Espanha (143) ${ }^{154}$.

Em 1936 constavam 10.008 prostitutas cadastradas em São Paulo. A maior parte delas - 5.400 mulheres - era estrangeira. As francesas representavam quase $6 \%$ do total, com 576 mulheres. Na sequência apareciam as polonesas (439), as portuguesas (413), as alemãs (375), as argentinas (351), as italianas (330), as russas (287) e as lituanas (282). 4.608 mulheres eram brasileiras. Do total, 8.077 eram brancas ${ }^{155}$.

No Rio de Janeiro ${ }^{156}$, as estatísticas caminham no mesmo sentido. No ano de 1912 o levantamento feito por um delegado apontou que, num total de 94 casas toleradas, havia 299 mulheres, sendo 160 estrangeiras. Em primeiro lugar apareciam as russas (33), depois as italianas (30), as espanholas (20) e as francesas (16).

\footnotetext{
${ }^{152}$ FONSECA, op. cit., p. 135-136.

${ }^{153}$ Idem, p. 138-140.

${ }^{154}$ Idem, p. 140-141.

155 Idem, p. 141-143.

${ }^{156}$ MENEZES, op. cit., p. 174.
} 
Conforme conclui Guido Fonseca ${ }^{157}$, a significativa presença de mulheres de determinadas nacionalidades, como Rússia, França e Polônia, só pode ser explicada pela ação do tráfico, pois a imigração desses povos para o Brasil não era comum. Quanto aos cáftens, eram em sua maioria estrangeiros ${ }^{158}$, mormente europeus. A pena para eles era, em regra, a expulsão ${ }^{159}$ do País.

As grandes correntes migratórias a partir do último quartel do século XIX e o crescente movimento do tráfico internacional de mulheres visando à prostituição obrigaram os Estados a se reunir para debater a questão e elaborar acordos internacionais visando prevenir e punir esse crime. Já em 1885, no Congresso Penitenciário de Paris, o tema foi debatido, e em 1899 aconteceu em Londres um Congresso Internacional sobre Tráfico de Escravas Brancas. Em 1902 ocorreu a Conferência de Paris, com a participação do Brasil.

Em 1904 foi assinado em Paris o Acordo Internacional para a Repressão do Tráfico de Mulheres Brancas, elaborado pela Liga das Nações e promulgado no Brasil pelo Decreto n. 5.591, de 13-7-1905. No ano de 1910 foi assinada a Convenção Internacional relativa à Repressão do Tráfico de Escravas Brancas, promulgada no Brasil pelo Decreto n. 4.756, de 28-11-1923, e pelo Decreto n. 16.572, de 27-8-1924.

Após a assinatura desses acordos, teve início a Primeira Guerra Mundial, que perdurou de 1914 a 1918. Durante esse período houve uma diminuição do tráfico, mas com o término da guerra os movimentos migratórios tomaram novo fôlego, impulsionados pela destruição e pelo estado de miséria dos países europeus. Assim, foi assinada em 1921 a Convenção Internacional para a Repressão do Tráfico de Mulheres e Crianças, promulgada no Brasil pelo Decreto n. 23.812, de 30-1-1934.

Em 1933 se firmou novo documento, a Convenção Internacional relativa à Repressão do Tráfico de Mulheres Maiores, a última sob o patrocínio da Liga das Nações, e promulgada pelo Brasil pelo Decreto n. 2.954, de 10-8-1938.

\footnotetext{
${ }^{157}$ FONSECA, op. cit., p. 143, 145-149.

${ }^{158}$ Lená Medeiros de Menezes, op. cit., p. 174, afirma que, em uma mostra de 161 processos de expulsão movidos no Rio de Janeiro, 59 cáftens eram russos ou poloneses, 33 eram franceses, 29 italianos, 22 portugueses e 18 espanhóis.

${ }^{159}$ Lená Medeiros de Menezes, op. cit., p. 171-172, dispõe sobre a expulsão de vários cáftens a partir de 1907, como o polonês Goldbery, apelidado de Rei dos Cáftens, sob a acusação de explorar o tráfico de brancas. Muitos desses homens já haviam sido expulsos de outros países sob a mesma acusação.
} 
Em 1950, já sob a égide da ONU, foi assinada a Convenção para a Repressão do Tráfico de Pessoas e do Lenocínio, promulgada no Brasil pelo Decreto n. 46.981, de 8-101959. Essa convenção foi a primeira a reconhecer que qualquer pessoa poderia ser vítima do crime de tráfico internacional de pessoas.

Finalmente, no ano 2000, foi aprovado o Protocolo Adicional à Convenção das Nações Unidas contra o Crime Organizado Transnacional, relativo à Prevenção, Repressão e Punição do Tráfico de Pessoas, em especial Mulheres e Crianças, e promulgado no Brasil pelo Decreto n. 5.017, de 12-3-2004 ${ }^{160}$.

Entre 1904 e 2000 observa-se a evolução da legislação internacional sobre a matéria. No tocante ao objeto de proteção, houve um alargamento, pois inicialmente a proteção era destinada apenas às "escravas brancas", avançando para "mulheres e crianças" e finalmente para "pessoas" ou "seres humanos".

Outra alteração se deu no tocante ao tratamento dispensado à vítima. Ao longo do tempo percebeu-se que a vítima desse tráfico carece de proteção e ajuda, e não deve ser tratada como criminosa. Essa postura constitui um dos objetivos do Protocolo de Palermo, nos termos de seu art. $2^{\circ}, b$ : "proteger e ajudar as vítimas desse tráfico, respeitando plenamente os seus direitos humanos".

Outro aspecto é o referente à abrangência. Até o advento do Protocolo de Palermo, a preocupação era apenas com a prostituição. Hoje o foco é a proteção de qualquer forma de exploração, seja ela de índole sexual, laboral ou de remoção de órgãos, ocasionada pelo tráfico internacional $^{161}$.

\footnotetext{
${ }^{160}$ Os acordos internacionais mencionados dispõem especificamente sobre o tráfico de pessoas tratado neste trabalho, que envolve adultos. Contudo, existem outros acordos que também dispõem sobre a matéria, em especial os que tratam dos direitos das crianças e das mulheres. Exemplos: Quarta Conferência Mundial sobre a Mulher, Beijing, 1995; Convenção Interamericana sobre o Tráfico Internacional de Menores, de 1994 (Decreto n. 2.740/98); Convenção Interamericana para Prevenir, Punir e Erradicar a Violência contra a Mulher, de 1994 (Decreto n. 1.973/96); Convenção sobre a eliminação de todas as formas de discriminação contra a mulher, de 1979 (Decreto n. 4.377/2002).

${ }^{161}$ Segundo entendimento da OIT, o fato de o Protocolo de Palermo distinguir tráfico para exploração sexual e tráfico para trabalho ou serviços forçados não significa que exploração sexual coercitiva não constitua trabalho forçado. Os órgãos supervisores da OIT têm em geral encarado a prostituição forçada e a exploração sexual sob a ótica da Convenção OIT n. 29, de 1930, que dispõe sobre trabalho forçado ou obrigatório. (Relatório Global da OIT, 2005, item 24. Disponível em: $<$ http://www.oit.org.br/sites/default/files/topic/forced_labour/pub/relatorio_global_2005_alianca_contra_trab alho_forcado_316.pdf>. Acesso em: 2 out. 2011).
} 
Nesse passo, a OIT $^{162}$ apoia o entendimento de que o tráfico humano envolve mais do que a exploração sexual de mulheres e de crianças, e que este também deve ser visto como um problema de trabalho forçado para o qual se exigem soluções baseadas no mercado de trabalho. Exemplo dessa nova postura foi o aumento das questões de trabalho forçado disponíveis no relatório anual do Governo dos Estados Unidos ${ }^{163}$ de apenas 20 referências em 2001 para 535 em 2008.

\subsection{A SOCIEDADE CONTEMPORÂNEA E O TRÁFICO DE PESSOAS PARA FIM DE EXPLORAÇÃO SEXUAL}

O século XX observou uma inversão dos fluxos migratórios, separados pelo interregno que se estendeu da Segunda Guerra Mundial aos anos 80. Se, no início do século a preocupação era com as escravas brancas, as europeias trazidas para a prostituição nas capitais sul-americanas como Rio de Janeiro e Buenos Aires, desde o final do século XX o que se vê são os países pobres e subdesenvolvidos como fornecedores de pessoas para a exploração sexual em nações ricas, especialmente para o mercado europeuocidental $^{164}$.

Embora os tempos sejam outros, muitas características do tráfico de outrora se mantiveram. Segundo Lená Medeiros de Menezes ${ }^{165}$, algumas práticas e algumas razões guardam semelhanças impressionantes, como se tivessem permanecido congeladas no tempo. São elas: caráter transnacional, vítimas vulneráveis; engodo durante o aliciamento; situação de escravidão por dívida no local de destino etc.

Hoje a globalização põe à disposição dos traficantes de pessoas todas as suas ferramentas utilizadas para fins lícitos, como a revolução dos meios de comunicação e a facilidade de transpor fronteiras. O tráfico é tratado como um negócio qualquer, e suas vítimas se transformaram em commodities. Os traficantes buscam suas mercadorias em ambientes vulneráveis, e as vendem nos mercados mais promissores.

\footnotetext{
162 Relatório Global da OIT, 2009, item 298. Disponível em: <http://www.oit.org.br/sites/default/files/topic/forced_labour/pub/custo_da_coercao_308.pdf >. Acesso em: 2 out. 2011.

${ }^{163}$ Trafficking in Persons Report ou TIP Report.

${ }^{164}$ Nesse sentido: Lená Medeiros de Menezes, op. cit., p. 176.

${ }^{165}$ MENEZES, op. cit., p. 174-175.
} 
Em sua maioria mulheres, essas escravas sexuais são forçadas a servir centenas ou até milhares de "clientes" antes de serem descartadas, morrerem ou conseguirem fugir. Trata-se de um negócio muito lucrativo, uma atividade ilícita mais simples e mais rentável que o tráfico de drogas, por exemplo. Ao contrário da droga, que precisa ser plantada, cultivada, industrializada e embalada, a mulher em si não é uma "mercadoria" ilícita, além de poder ser "utilizada" inúmeras vezes.

Essa atividade tão lucrativa e profusa só é possível com a estrutura do crime organizado, corrompendo policiais e agentes do governo. Segundo David Batstone ${ }^{166}$, do movimento Not for Sale, a máfia russa, por exemplo, é um grande expoente desse tipo de criminalidade. Presente em cada ação do tráfico sexual no leste europeu, também domina o tráfico em Israel e em muitos países da Europa ocidental, além da forte presença nos Estados Unidos, Canadá e sudeste da Ásia.

Diante desse cenário estarrecedor, hoje muito se fala em tráfico de pessoas, porém não há estatísticas ${ }^{167}$ suficientes para informar seu montante ou suas características. Lamentavelmente, trata-se ainda de um crime invisível. "Os dados existentes decorrem de diferentes fontes, colhidos por diferentes metodologias, em diferentes épocas, usando definições divergentes de tráfico de pessoas, por diferentes agências e por motivações muito diversas"168 e 169 .

A título ilustrativo, segundo dados disponíveis no site da Organização Internacional para as Migrações - $\mathrm{OIM}^{170}$, o tráfico internacional de pessoas é uma das três atividades mais lucrativas do crime organizado. Em 2005 se calculavam 2,4 milhões de vítimas de tráfico de pessoas trabalhando em condições de exploração no mundo todo.

\footnotetext{
${ }^{166}$ BATSTONE, David. Not for sale, p. 159-160. Segundo o autor, a estrutura dessas organizações e sua forma de trabalho guardam vários mistérios, pois o esforço de seus membros é para permanecerem na clandestinidade.

167 A UNESCO, por meio do Trafficking Statistics Project, alerta para o perigo das estatísticas: "The UNESCO TRAFFICKING STATISTICS PROJECT is a first step toward clarifying what we know, what we think we know, and what we don't know about trafficking". Disponível em: <http://www.unescobkk.org/index.php?id=1022>. Acesso em: 19 dez. 2011.

168 ANDERSON, B.; DAVIDSON, J. Trafficking - a demand led problem? Disponível em: <http://www.childtrafficking.com/Docs/anderson_o_connel_davidson_2004_trafficking_a_demand_led_p_1. pdf>. Acesso em: 3 dez. 2010, p. 15 (tradução nossa).

${ }^{169}$ Nesse sentido: Grupo Davida, Kamala Kempadoo e outros.

$170<$ http://www.oimconosur.org/varios/index.php?url=trata\#_ftn2>. Acesso em: 15 jan. 2011.
} 
O pesquisador Siddharth $\operatorname{Kara}^{171}$ afirma que em 2006 havia cerca de 28,4 milhões de pessoas vivendo como escravos em todo o mundo. São crianças indianas roubadas das famílias trabalhando 16 horas por dia no cultivo do chá ou na confecção de tapetes; adultos e crianças trabalhando no cultivo da cebola, abacate e milho nos Estados do Texas, Califórnia, Flórida e Carolina do Norte e do Sul; ou no cultivo do cacau na Costa do Marfim, do café na Etiópia e no Quênia e nas carvoarias no Brasil. Desses 28,4 milhões, Kara afirma que aproximadamente 1,2 milhão são jovens mulheres e crianças exploradas sexualmente.

Segundo dados fornecidos em 2010 pelo Escritório das Nações Unidas contra Drogas e Crime - UNODC ${ }^{172}$, a movimentação financeira envolvida no delito de tráfico de pessoas com fim de exploração sexual para a Europa alcança 3 bilhões de dólares anuais, e o número de novas vítimas é 70.000 por ano.

Ainda segundo dados do UNODC, $84 \%$ das vítimas traficadas para a Europa ocidental e central são destinadas à exploração sexual ${ }^{173}$.

Desse número, a maior parte ${ }^{174}$ é do leste europeu, em função dos problemas político-sociais que atingem essa região ${ }^{175}$. Das vítimas com origem na América do Sul, é cada vez maior o número de brasileiras, incluindo transexuais, provenientes principalmente das regiões mais pobres do País. Em segundo lugar aparecem as paraguaias ${ }^{176}$. As brasileiras têm como principais países de destino Portugal, Espanha, Itália e França ${ }^{177}$. Mas há brasileiras também nos Países Baixos, Alemanha, Áustria e Suíça.

\footnotetext{
${ }^{171}$ KARA, Siddharth. Sex trafficking: inside the business of modern slavery, p. IX e X. Trafficking in persons to Europe for sexual exploitation. Disponível em: $<$ http://www.unodc.org/southerncone/pt/trafico-de-pessoas/publicacoes.html>. Acesso em: 16 jan. 2011.

${ }^{173}$ Sobre essa questão, vide Gráfico 3 da OIT, no Anexo a este trabalho.

${ }_{175}^{174}$ Sobre a nacionalidade das vítimas, vide o Anexo a este trabalho: Mapa 1 e Gráfico 1.

${ }^{175}$ Segundo dados da OIM, de vítimas de tráfico identificadas, o tráfico de pessoas para fim de exploração sexual passou de 403 em 2004, para 584 em 2007. Já o tráfico para fim de exploração laboral saltou de 189 em 2004 para 500 em 2007. Esses números não são conclusivos, pois podem representar tanto o aumento da exploração laboral, como a maior eficácia de políticas públicas ou repressão nessa área. Disponível em: <http://www.oit.org.br/sites/default/files/topic/forced_labour/pub/custo_da_coercao_308.pdf >. Acesso em: 2 out. 2011.

${ }^{176}$ Sobre brasileiras e paraguaias na Espanha, vide Gráfico 2, no Anexo a este trabalho.

${ }^{177}$ Sobre o assunto, ver Mapa 2 no Anexo a este trabalho.
} 
O leste europeu é um grande fornecedor de mulheres para fim de exploração sexual. A rota entre os portos de Vlorë (Albânia) e San Foca (Itália) é uma das mais utilizadas ${ }^{178}$. As vítimas são, em regra, originárias dos países da antiga União Soviética, e passam pela Romênia, Sérvia, Montenegro ou Croácia, e daí para a rota Albânia-Itália, conhecida como Balkan Trail $^{179}$. Esses países, desde a queda da Cortina de Ferro no início dos anos 90, enfrentam toda sorte de dificuldades, guerras civis, violência e desemprego. A pobreza, aliada à esperança de migrar para o ocidente em busca de uma vida melhor, torna esses países um mercado fértil para traficantes.

Há um consenso nas fontes de pesquisa ${ }^{180}$ de que o número de mulheres e meninas traficadas é muito maior que o número de homens e meninos, chegando a $98 \%$ quando o objetivo é a exploração sexual.

Quanto aos estudos nacionais, o trabalho mais importante é a Pesquisa sobre Tráfico de Mulheres, Crianças e Adolescentes para fins de Exploração Sexual Comercial PESTRAF $^{181}$, realizada entre 2001 e 2002, que teve como mérito dar visibilidade a um fenômeno ainda pouco analisado no País.

Além de trazer depoimentos de prováveis vítimas do tráfico, a PESTRAF ${ }^{182}$ fornece dados como a identificação de 110 rotas de tráfico intermunicipal e interestadual e 131 rotas internacionais.

Romeu Tuma Júnior ${ }^{183}$ apresenta, também, números referentes a inquéritos e processos sobre tráfico de pessoas. Entre 1990 e 2008 foram instaurados 765 inquéritos

\footnotetext{
${ }^{178}$ BATSTONE, op. cit., p. 137-138, 143-144.

${ }^{179}$ Rota dos Bálcãs ou Rota da Península Balcânica (tradução nossa).

${ }^{180}$ Sobre a divisão por sexo, vide Gráfico 4 no Anexo a este trabalho.

${ }^{181}$ LEAL, Maria Lúcia. LEAL, Maria de Fátima P. (org.). Pesquisa sobre Tráfico de Mulheres, Crianças e Adolescentes para fins de Exploração Sexual Comercial - PESTRAF: Relatório Nacional - Brasil. Brasília: CECRIA, 2002.

${ }^{182}$ O Grupo Davida tece severas críticas à PESTRAF, pois, segundo eles, a pesquisa privilegia fontes que devem ser tratadas de maneira crítica. "Nesse relatório boa parte da contagem de rotas de tráfico de mulheres brasileiras para o exterior, assim como os relatórios de muitos dos casos de brasileiras supostamente extraditadas por via dessas rotas, é baseada em informações obtidas através da mídia e da Polícia Federal, sem analisar essas fontes". In: Prostitutas, "traficadas" e pânicos morais: uma análise da produção de fatos em pesquisas sobre o "tráfico de seres humanos". Cadernos Pagu, Campinas, n. 25, p. 153-184, jul./dez. 2005.

183 TUMA JÚNIOR, Romeu. A política e o plano nacional de enfrentamento ao tráfico de pessoas In: MARZAGÃO JÚNIOR, Laerte (coord.). Tráfico de pessoas. p. 282-283.
} 
policiais, observando-se um vertiginoso aumento a partir do ano 2000. Quanto às sentenças resultantes do tráfico, entre 2002 e 2008 , foram 211 condenações.

Vale mencionar que, assim como outros temas da seara penal, o tráfico de pessoas recebe um tratamento midiático sensacionalista. Alguns números podem ser exagerados e acabam sendo aceitos pela repetição, sem nenhuma investigação das suas origens. Esse "pânico moral""184 acaba por gerar mudanças legislativas e outras medidas de afogadilho, o que, em vez de proteger, exclui direitos. O que podemos afirmar é que não existem hoje estatísticas confiáveis para informar o montante ou as características precisas do tráfico de pessoas. Além disso, o conceito de tráfico do Código Penal brasileiro é diferente do conceito previsto no Protocolo de Palermo, além de existir grande confusão entre tráfico de pessoas e contrabando de migrantes, o que dificulta a produção de conhecimento e pesquisas precisas e coerentes. Conclui-se, então, que há ainda muito trabalho pela frente antes de se conseguir implementar medidas eficazes de enfrentamento ao tráfico de pessoas no Brasil e no mundo.

${ }^{184}$ Expressão cunhada pelo Professor de Sociologia Stanley Cohen, no livro Folk devils and moral panics, em 1972. 


\section{O TRÁFICO DE PESSOAS NO PANORAMA INTERNACIONAL}

A preocupação com o tráfico de pessoas é mundial. Seja como país de origem ou de destino, a maior parte das nações está envolvida por esse fenômeno. Muitas são suas causas $^{185}$, como a pobreza, a falta de acesso à educação, de emprego ou de oportunidades, a discriminação de gênero, étnica ou de religião, as crises humanitárias, os conflitos bélicos, os desastres naturais, a globalização ${ }^{186}$, o consumismo. Tudo isso torna o fenômeno muito abrangente.

Os Estados Unidos, como se verá a seguir, há onze anos elaboram um Relatório Mundial sobre o Tráfico de Pessoas. Segundo o Relatório ${ }^{187}$, a maioria dos países que nega a existência de vítimas do tráfico dentro de suas fronteiras ou não age de acordo com os mandamentos do Protocolo de Palermo ${ }^{188}$ ou com as necessidades da comunidade internacional. Segundo o documento, "não há vergonha na abordagem de um problema dessa magnitude; a vergonha está em ignorá-lo"189.

A abrangência da locução "tráfico de pessoas" pode induzir a interpretações errôneas. Assim, em primeiro lugar se fará a distinção entre o tráfico de pessoas para fim de exploração e o tráfico de migrantes ilegais, com o intuito de evitar o uso equívoco das expressões.

Em seguida, analisar-se-á o tratamento dispensando ao tráfico na América, Europa, Ásia e África. Atualmente muitos países têm alterado sua legislação acerca do tema. Assim, a escolha dos países para este estudo foi feita tendo em vista sua importância no cenário internacional, bem como a disponibilidade de dados recentes e atualizados.

\footnotetext{
${ }^{185}$ Sobre as possíveis causas do tráfico de pessoas, dispõem a PESTRAF, Introdução e depoimentos, e o site da OIM: <http://www.oimconosur.org/varios/index.php?url=trata_que>. Acesso em: 1 jan. 2011.

${ }^{186}$ Nesse sentido: COSTA, José de Faria. A globalização e o tráfico de seres humanos: o pêndulo trágico da história e o direito penal. In: Direito penal e globalização: reflexões não locais e pouco globais.

${ }^{187}$ Trafficking in Persons Report ou TIP Report.

188 Em informação disponível no site da ONU, até novembro de 2010 havia 117 países signatários do Protocolo de Palermo. Disponível em: <www.un.org>. Acesso em: 13 nov. 2010.

189 "Most countries that deny the existence of victims of modern slavery within their borders are not looking, trying, or living up to the mandates of the Palermo Protocol and the demands of our common humanity. There is no shame in addressing a problem of this magnitude; the shame lies in ignoring it" (tradução nossa). Disponível em: <http://www.state.gov/g/tip/rls/tiprpt/2010/index.htm>. Acesso em: 11 jan. 2010.
} 


\subsection{DISTINÇÃO ENTRE O TRÁFICO DE PESSOAS PARA FIM DE EXPLORAÇÃO E O TRÁFICO DE MIGRANTES ILEGAIS}

A expressão "tráfico de pessoas" é capaz de assumir diversas conotações, o que pode gerar equívocos na tipificação correta do fato, bem como no tratamento dispensado às "vítimas" e traficantes. Assim, é preciso atentar para utilizá-la de forma técnica, nos termos da legislação vigente.

A Convenção das Nações Unidas contra o Crime Organizado, também conhecida como Convenção de Palermo, foi promulgada pelo Decreto n. 5.015, de $2004^{190}$.

Essa Convenção tem por objetivo promover a cooperação para prevenir e combater mais eficazmente a criminalidade organizada transnacional. Para tanto, seu art. 37 estabelece que a Convenção poderá ser completada por meio de protocolos. Ao presente estudo interessam apenas dois:

- Protocolo adicional à Convenção das Nações Unidas contra o Crime Organizado Transnacional, relativo ao Combate ao Tráfico de Migrantes $^{191}$ por via Terrestre, Marítima e Aérea, promulgado pelo Decreto n. 5.016, de $2004^{192}$; e

- Protocolo adicional à Convenção das Nações Unidas contra o Crime Organizado Transnacional, relativo à Prevenção, Repressão e Punição do Tráfico de Pessoas, em especial Mulheres e Crianças, promulgado pelo Decreto n. 5.017, de $2004^{193}$.

Cabe então diferenciar a matéria tratada em ambos os Protocolos, a fim de que não se confunda tráfico de migrantes ilegais com tráfico de pessoas para fins de exploração.

O Protocolo promulgado pelo Decreto n. 5.016, de 2004, define em seu art. $3^{\circ}$ o tráfico de migrantes como a promoção, com o objetivo de obter, direta ou indiretamente,

\footnotetext{
${ }^{190}$ A Convenção de Palermo entrou em vigor internacional em 29-9-2003 e para o Brasil em 28-2-2004.

${ }^{191} \mathrm{O}$ tráfico de migrantes é também conhecido como contrabando de migrantes (smuggling of migrants ou people smuggling).

192 Este Protocolo entrou em vigor internacional em 29-9-2003 e para o Brasil em 28-2-2004.

193 Este Protocolo, conhecido como Protocolo de Palermo, entrou em vigor internacional em 29-9-2003 e para o Brasil em 28-2-2004.
} 
um benefício financeiro ou outro benefício material, da entrada ilegal de uma pessoa num Estado do qual essa pessoa não seja nacional ou residente permanente.

O Protocolo de Palermo, promulgado pelo Decreto n. 5.017, de 2004, define o tráfico de pessoas, em seu art. $3^{\circ}$, como o recrutamento, o transporte, a transferência, o alojamento ou o acolhimento de pessoas, recorrendo à ameaça ou ao uso da força ou a outras formas de coação, ao rapto, à fraude, ao engano, ao abuso de autoridade ou à situação de vulnerabilidade ou à entrega ou aceitação de pagamentos ou benefícios para obter o consentimento de uma pessoa que tenha autoridade sobre outra para fins de exploração. Essa exploração incluirá, no mínimo, a exploração da prostituição de outrem ou outras formas de exploração sexual, o trabalho ou serviços forçados, escravatura ou práticas similares à escravatura, a servidão ou a remoção de órgãos.

Nos termos da Organização Internacional para as Migrações - OIM ${ }^{194}$, o tráfico de pessoas previsto no Protocolo de Palermo é um processo de coação e exploração que se inicia com o recrutamento da pessoa em seu lugar de origem e continua com a exploração nos locais de trânsito e de destino.

Com base nessas definições podemos traçar algumas distinções ${ }^{195}$ entre o tráfico de pessoas para fins de exploração e o tráfico ou contrabando de migrantes.

A finalidade do tráfico de pessoas é a exploração, de qualquer natureza. Consiste ela em ganhar dinheiro com a pessoa traficada, transformando-a em objeto, que pode ser comercializado e explorado. Já no caso do tráfico de migrantes, a intenção é apenas promover a entrada de forma ilegal em determinado país mediante uma contraprestação financeira. A renda obtida com o tráfico de pessoas é contínua, advinda da exploração, ao passo que no tráfico de migrantes encerra-se em apenas uma transação.

Tendo em vista a finalidade do tráfico, podemos identificar quem é a "vítima” para cada situação distinta.

\footnotetext{
${ }^{194}$ Disponível em: <http://www.oimconosur.org/varios/index.php?url=trata_que>. Acesso em: 11 jan. 2011.

${ }^{195}$ Sobre o assunto vide ISELIN, Brian; ADAMS, Melanie. Distinguishing between Human Trafficking and People Smuggling. Disponível em: <http://www.embraceni.org/wpcontent/uploads/2006/06/Distinguishing\%5B1\%5D1.pdf>. Acesso em: 15 nov. 2010.; e MENDES, Paulo de Sousa. Tráfico de Pessoas. Disponível em: <http://www.estig.ipbeja.pt/ ac_direito/traficopessoassm.pdf $>$. Acesso em: 14 nov. 2010.
} 
No caso do tráfico de pessoas para fim de exploração, a vítima é a pessoa traficada. O Protocolo de Palermo recomenda aos Estados-Partes, em seus arts. $6^{\circ}$ a $8^{\circ}$, a proteção das vítimas desse crime.

No caso do tráfico de migrantes ilegais, o Estado aparece como vítima, pois tem sua legislação sobre migração violada tanto pelo traficante como pelo traficado.

Ao contrário do Protocolo de Palermo, segundo o qual a pessoa traficada para fim de exploração é considerada vítima (arts. $6^{\circ}$ a $8^{\circ}$ do Decreto n. 5.017, de 2004), o Protocolo relativo ao combate ao tráfico de migrantes dispõe que o migrante é o "objeto" do tráfico (art. $5^{\circ}$ do Decreto n. 5.016, de 2004). Estes não devem estar sujeitos a processos criminais, e têm a garantia da proteção de seus direitos individuais. Respeitadas essas determinações, o tratamento dispensado aos migrantes ilegais dependerá da legislação de cada país.

Pode acontecer de o migrante ilegal ser vítima de outros crimes durante o processo migratório, como o estupro ou o roubo. O exemplo é o que a mídia denuncia sobre a travessia ilegal do México para os Estados Unidos ${ }^{196}$, situação em que os migrantes ficam expostos a uma situação de vulnerabilidade, sujeitos à violência dos coiotes. Porém, tais delitos não configuram a exploração nos termos do Protocolo de Palermo. Embora o migrante ilegal possa ser vítima de roubo ou estupro, não o será do tráfico ou contrabando de migrantes.

A entrada em território estrangeiro da pessoa traficada para fim de exploração pode dar-se de forma lícita, com visto e passaporte válidos, ou ilícita. Esta última possibilidade pode induzir a erro, levando a crer que se trata de contrabando de migrantes. A forma de fazer essa distinção é avaliar a finalidade do tráfico. Se praticado apenas para cruzar a fronteira, configura tráfico de migrantes ilegais; porém, se há o escopo de exploração, trata-se do tráfico de pessoas nos termos do Protocolo de Palermo. Vale ressaltar que eventual falsificação de documentos ou qualquer outro meio fraudulento para que essa pessoa entre no País, será considerado apenas mais uma infração para alcançar o intento maior: a exploração

\footnotetext{
196 Como exemplo vide: BRAGON, Rayder. "Exportadora" de imigrantes, Governador Valadares (MG) combate ação de aliciadores. Disponível em: <http://noticias.uol.com.br/cotidiano/2010/09/02/exportadorade-imigrantes-governador-valadares-mg-combate-acao-de-aliciadores.jhtm>. Acesso em: 11 jan. 2011.
} 
Cabe ressaltar que na prática é muito comum essa confusão entre o traficado para o fim de exploração e o migrante ilegal ${ }^{197}$. Num posto de fronteira, por exemplo, não há como distinguir os dois casos sem a devida investigação ${ }^{198}$. Assim, a vítima do tráfico é vitimizada novamente, podendo ser presa e deportada como simples migrante ilegal ${ }^{199}$.

No tocante ao consentimento ${ }^{200}$, no tráfico de pessoas muitas vezes a vítima viaja coagida ou investida em erro, tendo, assim, seu consentimento viciado. Já a pessoa contrabandeada sabe o que está contratando e consente.

No caso de tráfico com fim de exploração sexual, muitas vítimas são originalmente contratadas para outras atividades econômicas. Em alguns países é comum as mulheres migrantes requererem visto de diversão, para trabalhar em atividades artísticas. Esse sistema, que tem sido objeto de fortes críticas nos últimos anos, acaba oferecendo uma cobertura legal para o tráfico de mulheres ${ }^{201}$.

São comumente noticiados na mídia ${ }^{202}$ casos de mulheres contratadas para serem atrizes, bailarinas, modelos, cantoras, garçonetes que, chegando ao país de destino, são forçadas a prestar serviços sexuais. Outro método de recrutamento utilizado é o

${ }^{197}$ No aeroporto internacional de Guarulhos, em São Paulo, há um "Posto de Atendimento Humanizado aos Migrantes", que visa a identificação e o apoio a mulheres e trans (travestis, transexuais e transgêneros), vítimas do tráfico de pessoas. A obra Sistematização da experiência de funcionamento do posto, de 2009, numa parceria do Ministério da Justiça, SNJ e UNODC, traz relatos que deixam evidente essa confusão entre traficados e migrantes ilegais.

${ }^{198}$ Nesse sentido: ISELIN, Brian; ADAMS, Melanie. Distinguishing between Human Trafficking and People Smuggling. Disponível em: <http://www.embraceni.org/wpcontent/uploads/2006/06/Distinguishing\%5B1\%5D1.pdf>. Acesso em 15 nov. 2010.

${ }^{199}$ Sobre a questão da violação de direitos humanos de emigrantes brasileiros deportados ou inadmitidos, vide o artigo Xenofobia ou "misoxenia": leitura das fichas da PF na perspectiva dos direitos humanos de Roberto Marinucci, In: MARINUCCI, Roberto; FARIAS, Yara; SANTIN, Terezinha (coord.). Trajetórias interrompidas: cidadãos brasileiros deportados e não admitidos, p. 43-67.

${ }^{200}$ A questão do consentimento será desenvolvida no Capítulo 7.

201 Relatório Global da OIT, 2005, item 244. Disponível em: $<$ http://www.oit.org.br/sites/default/files/topic/forced_labour/pub/relatorio_global_2005_alianca_contra_trab alho_forcado_316.pdf>. Acesso em: 15 nov. 2011.

${ }^{202}$ Exemplos: 1) "Caso Kelly": 26 anos, divorciada, 2 filhos (6 e 12 anos), ensino fundamental incompleto, moradora do subúrbio carioca, trabalhava como doméstica e guardadora de carros. Foi aliciada em uma festa por duas mulheres que moravam perto de sua casa, e contratada para trabalhar em lanchonetes ou casa de família em Israel. Chegando ao país foi privada de seus documentos e mantida em cárcere privado, obrigada a drogar-se e a prostituir-se com cerca de 10 homens por noite. Aproximadamente 2 anos depois da partida, ligaram para sua mãe informando que ela havia morrido de overdose. A morte nunca foi esclarecida (PESTRAF, p. 112-117). 2) "Caso Sukie": 25 anos, separada, 2 filhos, desempregada, morava com a mãe que vendia churrasquinho em Manaus. Foi aliciada por duas mulheres em um ponto de ônibus para trabalhar com turismo ou como garçonete na Espanha. Chegando lá foi privada de seus documentos e obrigada a prostituir-se. Após brigar com a dona do bordel fugiu para Portugal, de onde foi deportada para o Brasil (PESTRAF, p. 158-160). 
“casamento" com estrangeiros. Nessa situação há tanto casos de exploração sexual como de exploração de trabalho doméstico.

O pagamento também é um diferencial. No tráfico de pessoas o valor despendido com a viagem é, em regra, cobrado do traficado quando este chega ao destino, e a um preço muito elevado, o que faz com que se crie uma grande dívida: o traficado coloca-se em posição de sujeição diante do traficante.

Já no tráfico de migrantes o valor que cobre as despesas da viagem e os "serviços" prestados pelo traficante é ajustado antecipadamente. Fica evidenciada, aqui, uma prestação de serviços, ou seja, uma relação de consumo.

Nas palavras do professor português Paulo de Sousa Mendes ${ }^{203}$, no tráfico de pessoas a pessoa traficada é vítima, ao passo que no tráfico de migrantes a pessoa contrabandeada é cliente.

Quanto ao destino, o tráfico de pessoas pode dar-se tanto no âmbito internacional quanto no nacional. O tráfico de migrantes, por sua vez, é uma infração transnacional na essência, pois visa a entrada ilegal de uma pessoa em país do qual não seja nacional ou não resida de forma permanente.

Segundo relatos ${ }^{204}$, no tráfico de pessoas a vítima, ao chegar ao destino, é privada de seus documentos pessoais, em especial o passaporte, ficando sob a guarda de outrem, sendo inclusive confinada em locais de onde não pode fugir, sujeitando-se a maus-tratos. Já no tráfico de migrantes, no momento em que o contratante/traficado chega ao país de destino, encerra-se o trabalho do traficante.

203 MENDES, Paulo de Sousa. Tráfico de Pessoas. Disponível em: <http://www.estig.ipbeja.pt/ ac_direito/traficopessoassm.pdf>. Acesso em: 14 nov. 2010.

${ }^{204}$ Relatos analisados: PESTRAF; CPMI da Exploração Sexual; Meninas da Noite de Gilberto Dimenstein; Not for Sale de David Batstone; Sujeição ou subversão: migrantes brasileiras na indústria do sexo na Espanha de Adriana Piscetelli; Metade do céu de Nicholas Kristof e Sheryl Wudunn; e Sex trafficking: inside the business of modern slavery de Siddharth Kara; e os documentários Cinderelas, lobos e um príncipe encantado, e Eldorado: docudrama sobre tráfico de pessoas. 
Em linhas gerais, essas são as principais diferenças entre o tráfico de pessoas e o tráfico de migrantes ilegais. A seguir, analisar-se-á a forma como alguns países americanos, europeus, asiáticos e africanos cuidam da matéria.

\subsection{AMÉRICA}

O continente americano segue os padrões mundiais sobre o tráfico de pessoas. Os países da América Latina são fonte de migrantes para os Estados Unidos e Canadá. Porém, existe também o tráfico regional (entre os países latinos) e o interno (dentro de cada país).

O Brasil é fonte e destino de pessoas traficadas. Brasileiras escravas sexuais podem ser encontradas em países de fronteira como Venezuela ${ }^{205}$, Suriname ${ }^{206}$, Guiana Francesa $^{207}$ etc., bem como se podem encontrar aqui muitos bolivianos no trabalho escravo, em especial na indústria têxtil, em grandes centros como São Paulo ${ }^{208}$.

\subsubsection{Estados Unidos}

Nos Estados Unidos a tutela legal do tráfico de pessoas se dá por meio do Victims of Trafficking and Violence Protection Act, de 2000 - TVPA, além do Protocolo de Palermo.

Segundo a legislação norte-americana, o tráfico de pessoas para fins sexuais, ou sex trafficking, inclui o recrutamento, acolhimento, transporte, provisão ou obtenção de uma

\footnotetext{
${ }^{205}$ A fronteira entre Pacaraima (Brasil) e Santa Elena de Uairén (Venezuela) é uma rota muito utilizada para o tráfico sexual motivada pela fragilidade e falta de fiscalização. Sobre o assunto, veja: PIMENTEL, Geyza Alves; OLIVEIRA, Rafael da Silva. Tráfico de mulheres para fim de exploração sexual comercial na fronteira Brasil-Venezuela: o caso da BR-174, p. 59-73.

${ }^{206}$ O Suriname não constitui apenas um lugar de trânsito para a Europa, especialmente a Holanda, mas também local de destino final. Segundo dados do ano 2005 do serviço de saúde que faz exames periódicos nas prostitutas atuantes nos clubes da capital, foram registradas 308 brasileiras no País. Sobre o tráfico de brasileiras para o Suriname, veja: HAZEU, Marcel (coord.). Pesquisa trinacional sobre tráfico de mulheres do Brasil e da República Dominicana para o Suriname: uma intervenção em rede, p. 11.

${ }^{207}$ A fronteira entre Oiapoque (Brasil) e Saint-Georges (Guiana Francesa) é local com grande quantidade de prostitutas, inclusive crianças, pois se trata de região de garimpo. Sobre o tráfico de pessoas nessa região, veja: CONTE, Maria Irene De. A ponte sobre o rio Oiapoque: uma ponte "transoceânica" entre o Brasil e a França; o MERCOSUL e a União Europeia?

${ }^{208}$ ILLES, Paulo; TIMOTEO, Gabrielle Louise Soares; FIORUCCI, Elaine da Silva. Tráfico de Pessoas para fins de exploração do trabalho na cidade de São Paulo. Cadernos Pagu, n. 31, p. 199-217.
} 
pessoa com a finalidade de um ato sexual comercial. Esse ato sexual deve ser induzido pela força, fraude ou coerção, ou envolver menor de 18 anos.

Contudo, a legislação não se esgota na preocupação com a indústria do sexo, e inclui também as demais formas de tráfico, como o realizado para a exploração laboral doméstica, na agricultura ou na servidão por dívida. As penas variam entre 5 e 20 anos de prisão, podendo chegar até mesmo à prisão perpétua ${ }^{209}$.

Um ponto de destaque refere-se ao Relatório sobre o Tráfico de Pessoas ${ }^{210}$, elaborado anualmente no País - TIP Report. O governo americano afirma que o Relatório é uma ferramenta diplomática que incentiva outros países a combaterem todas as formas de escravidão moderna.

Nesse Relatório os países são divididos em categorias (tiers), que variam de 1 a $3^{211}$. Estas, ainda segundo o governo norte-americano, refletem os esforços realizados por cada um dos países, e todos são avaliados na mesma medida utilizada para avaliar os Estados Unidos. Assim, eles estão na categoria (tier) 1, pois cumprem um mínimo exigível segundo seus próprios critérios. Esse standard exigido pelos países está descrito na seção 108 do TVPA, e inclui o aprimoramento de ações visando: a prevenção, a proibição e a punição das diversas formas de tráfico, bem como a proteção das vítimas.

${ }^{209}$ TIP Report 2011. Disponível em: <http://www.state.gov/g/tip/rls/tiprpt/2011/164233.htm>. Acesso: em 9 jan. 2012.

${ }_{210}$ Trafficking in Persons (TIP) - $\quad$ Report 2011. Disponível em: <http://www.state.gov/g/tip/rls/tiprpt/2011/index.htm>. Acesso em: 14 nov. 2011.

211 “Tier 1 - Countries whose governments fully comply with the Trafficking Victims Protection Act's (TVPA) minimum standards.

Tier 2 - Countries whose governments do not fully comply with the TVPA's minimum standards, but are making significant efforts to bring themselves into compliance with those standards.

Tier 2 watch list - Countries whose governments do not fully comply with the TVPA's minimum standards, but are making significant efforts to bring themselves into compliance with those standards AND:

a) The absolute number of victims of severe forms of trafficking is very significant or is significantly increasing;

b) There is a failure to provide evidence of increasing efforts to combat severe forms of trafficking in persons from the previous year; or

c) The determination that a country is making significant efforts to bring itself into compliance with minimum standards was based on commitments by the country to take additional future steps over the next year.

Tier 3 - Countries whose governments do not fully comply with the minimum standards and are not making significant efforts to do so". Disponível em: <http://www.state.gov/g/tip/rls/tiprpt/2011/164228.htm>. Acesso em: 1 jan. 2012. 
O Brasil está na categoria (tier) 2 do TIP Report 2011, ou seja, não atinge esse mínimo exigível, mas está se esforçando para isso. Os países avaliados com conceito 3 não atingem o mínimo, nem se mostram interessados em alcançá-lo. São, assim, passíveis de sofrer sanções impostas pelos Estados Unidos ou pela comunidade internacional. Existe também a categoria tier 2 watch list, para países que buscam uma melhora na situação do tráfico, mas o número absoluto de vítimas é muito alto ou está aumentando, por exemplo.

Não obstante a intenção possa parecer boa, na verdade esse Relatório reflete as relações exteriores dos norte-americanos, o que lhe retira a credibilidade ${ }^{212}$. Nesse sentido, David Batstone $^{213}$, do movimento Not for Sale, afirma que é desanimador ver os Estados Unidos atribuir a tier 1 a países como Holanda e Alemanha, que têm problemas significativos com o tráfico. Em sentido contrário, os jornalistas Kristof e Wudunn ${ }^{214}$ declaram que o Relatório é responsável pelo fomento da questão, já que pela primeira vez as embaixadas americanas tiveram de reunir informações sobre o crime. Os diplomatas americanos realizaram discussões com ministros das relações exteriores dos países pesquisados, que acrescentaram às suas agendas internas a questão do tráfico de pessoas.

Segundo crítica de Kamala Kempadoo ${ }^{215}$, a postura antitráfico americana demanda concordância de todo o mundo com sua postura neoconservadora cristã antiaborto, antiprostituição e pró-abstinência. Cita como exemplo a política adotada em 2003 pelos funcionários de campo da USAID ${ }^{216}$. Eles foram instruídos pelo Secretário de Estado (à época, Colin Powel) de que a ajuda deveria dar preferência à abstinência em relação ao preservativo na luta contra HIV/AIDS e não deveria apoiar projetos de trabalho sexual, programas de troca de agulhas ou serviços de aborto.

Segundo o Relatório ${ }^{217}$, os Estados Unidos aparecem como país de origem, trânsito e especialmente destino de pessoas traficadas. Os números são ainda imprecisos para afirmar qual é a finalidade prevalente do tráfico: laboral ou sexual. Nos termos do Relatório, as vítimas cidadãs americanas são predominantemente encontradas no tráfico para exploração sexual. Já os estrangeiros são maioria no tráfico para fỉm de exploração

\footnotetext{
${ }^{212}$ KEMPADOO, Kamala. Mudando o debate sobre o tráfico de mulheres. Cadernos Pagu, n. 25, p. 73-75.

${ }^{213}$ BATSTONE, David. Not for sale, p. 176.

${ }^{214}$ KRISTOF, Nicholas; WUDUNN, Sheryl. Metade do céu, p. 59.

${ }^{215}$ KEMPADOO, op. cit., p. 76.

${ }^{216} \mathrm{http} / / /$ www.usaid.gov/

${ }^{217}$ Disponível em: <http://www.state.gov/g/tip/rls/tiprpt/2011/164233.htm>. Acesso em: 24 out. 2011.
} 
laboral. Segundo o Departamento de Justiça americano ${ }^{218}$, estima-se que de 14.500 a 17.500 vítimas de tráfico humano são levadas para o País a cada ano ${ }^{219}$.

Assim como acontece no Brasil, as vítimas desse crime nos Estados Unidos são em sua maioria vulneráveis, oriundas de classes sociais inferiores, lares desestruturados, que sofreram abuso sexual na infância, viciadas em drogas. Porém, o tráfico não poupa classe social ou etnia, e até mesmo lá há relatos de vítimas brancas e de classe social elevada ${ }^{220}$.

Nos últimos anos houve nos Estados Unidos um crescimento de acusações criminais envolvendo o tráfico de pessoas. Segundo o Relatório Global da OIT de $2009^{221}$, medida importante foi a criação, em janeiro de 2007, da Unidade de Ação contra o Tráfico Humano, que forma parte da Seção Criminal da Divisão dos Direitos Civis do Departamento de Justiça. Nesse mesmo ano se verificou um número recorde de condenações desde a promulgação da Lei de Proteção às Vítimas de Tráfico, em 2000. As 103 condenações incluíam 17 por tráfico laboral e 86 por tráfico sexual. As penas de prisão foram em média de 11 anos, mais cerca de US\$ 2 milhões em bens dos traficantes, e o pagamento de restituições de mais de US\$ 3 milhões.

No ano 2010, segundo dados do governo americano $^{222}$, foram processados 181 indivíduos, e 141 foram condenados em 103 processos $^{223}$ de tráfico de seres humanos (sendo 32 de tráfico para exploração laboral e 71 para exploração sexual). Esse número representa o maior número de processos federais de tráfico de seres humanos iniciado em um único ano. A pena média de prisão foi de 11,8 anos.

\footnotetext{
218 "Each year, an estimated 600,000 to 800,000 men, women and children are trafficked against their will across international borders. Of those, 14,500 to 17,500 are trafficked into the United States". (tradução nossa). Disponível em: <http://www.ojp.usdoj.gov/archives/pressreleases/2004/DOJ04760.htm>. Acesso em: 24 out. 2011.

${ }^{219}$ Esses números, como todos os outros apresentados neste estudo, devem ser avaliados com parcimônia, apenas a título ilustrativo e não científico.

${ }^{220}$ A obra The slave across the street traz o relato de Theresa Flores, uma adolescente americana de classe média alta que foi escravizada sexualmente por um grupo étnico em Detroit, no início dos anos 80.

$\begin{array}{llllll}221 & \text { Itens } & 168 & \mathrm{e} & 169 . & \text { Disponível }\end{array}$ <http://www.oit.org.br/sites/default/files/topic/forced_labour/pub/custo_da_coercao_308.pdf >. Acesso em 2: out. 2011.

${ }^{222}$ Disponível em: <http://www.state.gov/g/tip/rls/tiprpt/2011/164233.htm>. Acesso em: 24 out. 2011.

${ }^{223}$ Esses processos são federais. Ainda não há dados concretos sobre os processos em nível estadual.
} 
Para Kristof e Wudunn ${ }^{224}$, o movimento abolicionista norte-americano seria muito mais eficiente se promovesse uma unidade de pensamento. Um grande motivo de discórdia é a questão da prostituição. Parte dos congressistas refere-se a ela de forma neutra, como trabalhadores sexuais. A outra parte vê a prostituição como aviltante e ofensiva, em qualquer de suas formas. As posturas antagônicas os impedem de trabalhar juntos em algo que todos consideram repugnante: a prostituição forçada e a prostituição infantil.

\subsubsection{América Latina}

A maior parte dos países da America Latina é vista pelo TIP Report 2011 como tier 2 (ex. Brasil, Argentina, Bolívia, Chile, México, Paraguai, Peru, Suriname, Uruguai), conforme mapa abaixo:

Mapa 1 - América (Tier Placements - TIP Repor 2011) 225

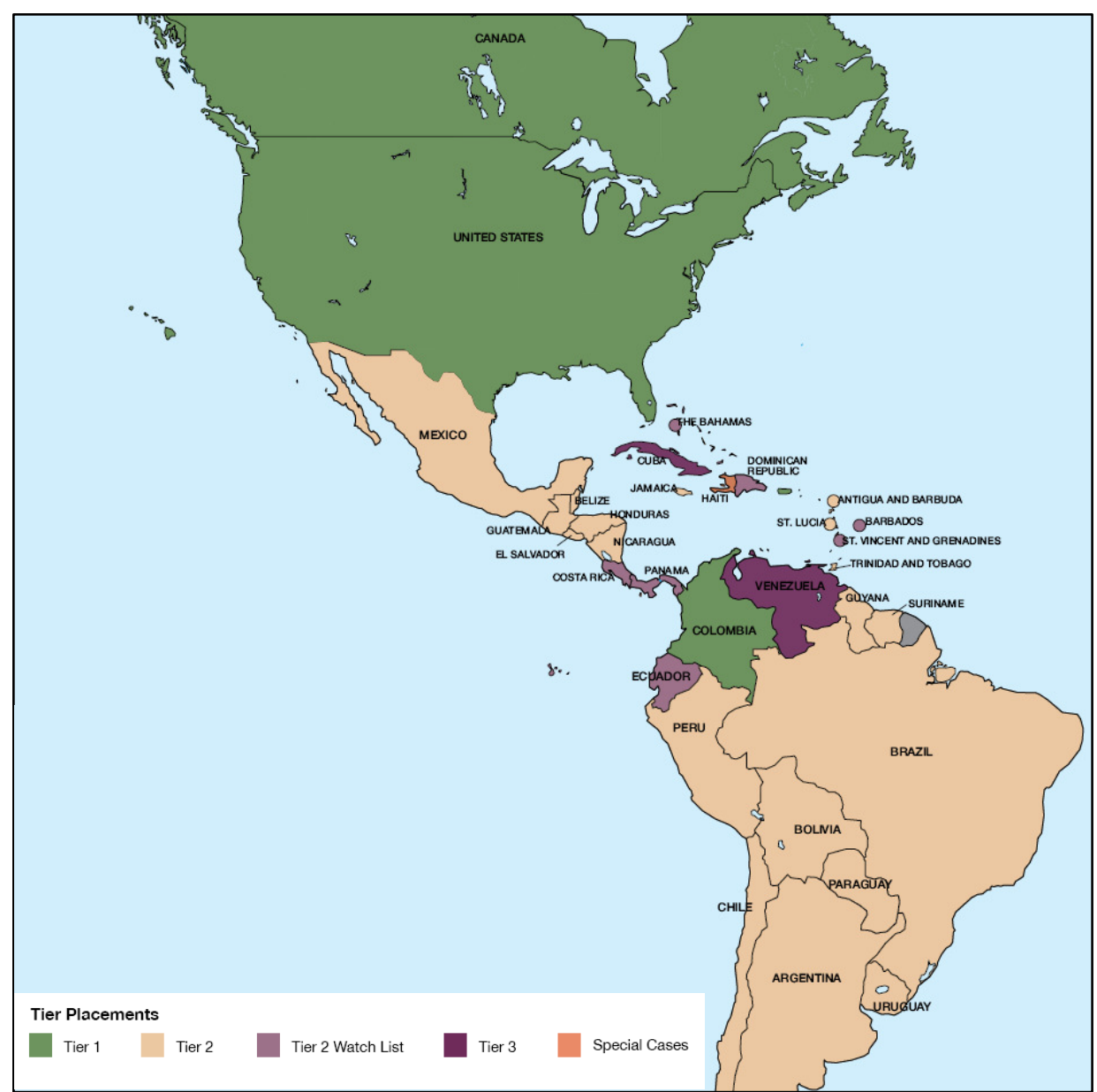

${ }^{224}$ KRISTOF e WUDUNN, op. cit., p. 51-52.

${ }^{225}$ Disponível em: <http://www.state.gov/g/tip/rls/tiprpt/2011/>. 
As exceções mais relevantes são Cuba e Venezuela com tier 3, e a Colômbia ${ }^{226}$ com tier 1. O Haiti foi considerado um caso especial, tendo em vista o destruição do país pelo terremoto ocorrido em 2010.

Segundo o Relatório, embora haja problemas graves relacionados ao tráfico na Colômbia, o governo do país cumpre plenamente os padrões mínimos para a sua eliminação. Com relação a Cuba e a Venezuela a situação é mais delicada, especialmente porque os Estados Unidos não mantêm boas relações com esses países, o que pode levar a perda de credibilidade da avaliação.

Cuba é um país extremamente fechado, e durante o período de elaboração do Relatório não divulgou informações sobre as medidas do governo para enfrentar o tráfico. Além disso, o país não é signatário do Protocolo de Palermo, o que justificaria o tier 3.

A Venezuela é signatária de todos os acordos internacionais relacionados no Relatório, porém a atitude do governo foi considerada insuficiente no cumprimento dos padrões mínimos, sem nenhuma manifestação de melhora nos últimos 4 anos, enquanto o país estava no tier 2, watch list. Nos termos do Relatório, a Venezuela é um país de origem, trânsito e destino para homens, mulheres e crianças vítimas de tráfico sexual e trabalho forçado. Mulheres e meninas venezuelanas são encontradas em condições de tráfico sexual no país, atraídas de regiões pobres do interior para centros urbanos e turísticos, como Caracas, Maracaibo e Ilha Margarita. As vítimas geralmente são recrutadas por meio de falsas ofertas de emprego. No país existem também mulheres brasileiras e colombianas submetidas à prostituição forçada.

Após o advento do Protocolo de Palermo, vários países alteraram a sua legislação sobre o tráfico de pessoas, ou criaram novos dispositivos ou mesmo normas inteiras para tratar da matéria.

\footnotetext{
${ }^{226}$ Os dados referentes ao tráfico de pessoas ainda são muito incipientes e desencontrados. Ao mesmo tempo que os Estados Unidos concedem tier 1 à Colômbia, o advogado argentino Hugo Bauché afirma que: "Entre los países más afectados de Latinoamérica se encuentran Colombia y la República Dominicana". In: Trata de personas: cosificación y negación de la persona como sujeto de derecho, p. 40.
} 
A Colômbia ${ }^{227}$ alterou seu Código Penal por meio da Lei n. 985, de 2005. O Peru promulgou a Lei n. 28.950, de 2007, contra o tráfico de pessoas e o tráfico ilícito de migrantes.

A Argentina possui uma norma específica para dispor sobre o tráfico de pessoas, que, apesar de promulgada sob a égide do Protocolo de Palermo, recebe diversas críticas. Trata-se da Lei n. 26.364, de 29-4-2008 - Prevención y sanción de la trata de personas y asistencia a sus víctimas, que além de trazer disposições próprias, altera o art. 145 do Código Penal argentino, integrante do capítulo referente aos delitos contra a liberdade individual.

Zunilda Niremperger e Francisco Rondan ${ }^{228}$ afirmam que embora a norma tenha suprido um vazio legislativo, não esgota todas as possibilidades de condutas relacionadas ao tráfico, e nem orienta para a solução de questões interpretativas. Os autores destacam como pontos mais deficientes a não criminalização do cliente que utiliza dolosamente os serviços de pessoa em situação de tráfico, bem como a aparente obrigação da vítima maior de 18 anos ter que demonstrar que não consentiu com a os maus tratos ou com o exercício da prostituição.

Segundo Elena Florencia Onassis ${ }^{229}$, a ausência de legislação adequada constitui um dos principais obstáculos na luta contra o tráfico de pessoas. Para a autora é imperiosa a necessidade do País harmonizar as definições legais, os procedimentos jurídicos e a cooperação judicial no plano local e regional, de acordo com as normas internacionais. A autora $^{230}$ também critica as omissões da lei, pois esta não dispõe sobre a responsabilização da pessoa jurídica, "lavagem" de dinheiro, punição do cliente, tratamento especial às vítimas e procedimentos penais específicos.

\footnotetext{
${ }^{227} \mathrm{O}$ art. 188A do Código Penal colombiano pune com prisão de 13 a 23 anos e multa aquele que aliciar, trasladar, acolher ou receber alguém - seja internamente ou a partir do exterior - com finalidade de exploração. O consentimento da vítima a qualquer das formas de exploração não afasta a responsabilidade penal. A exploração é definida como a obtenção de proveito econômico ou qualquer outro benefício para si ou outra pessoa, mediante a exploração da prostituição alheia ou outras formas de exploração sexual, do trabalho ou serviços forçados, da escravidão ou práticas análogas, da servidão, da exploração da mendicância alheia, do casamento servil, da extração de órgãos, do turismo sexual ou de outras formas de exploração. In: BAUCHÉ, op. cit., p. 191.

${ }^{228}$ NIREMPERGER, Zunilda; RONDAN; Francisco. Mercaderes de vida: una visión histórica, sociológica y jurídica del delito de trata de personas, p. 74-75.

${ }_{229}^{29}$ FLORENCIA ONASSIS, Elena. Trata de personas: la esclavitud del siglo XXI, p. 20.

${ }^{230}$ Idem, p. 128.
} 
A Argentina ${ }^{231}$, desde a ratificação do Protocolo de Palermo em 2002, tem implementado medidas visando a prevenção ao crime, como desenvolvimento de campanhas de conscientização de agentes governamentais, organizações da sociedade civil, agentes comunitárias, sindicatos, estudantes universitários e secundários, entre outros. Além disso, foram firmados convênios interministeriais e com organizações internacionais, como OIM, UNICEF e UNODC. Contudo, ainda não existem estatísticas oficiais centralizadas, e há preocupação com o fortalecimento das organizações criminosas e o aumento estimado do número de casos de tráfico de pessoas ${ }^{232}$.

Em síntese, a situação argentina se assemelha muito à brasileira. Para Elena Florência Onassis ${ }^{233}$ :

La República Argentina, carente de uma legislación adecuada y de mecanismos institucionales de asistencia, prevención, protección y de una política de persecución penal de este delito, presenta facilidades para el desarrollo de esta actividad ilegal. Hasta que no se realice seriamente, y no mediante legislaciones de emergencia, un programa de lucha contra la Trata de Personas, el fenômeno, continuará aumentando y las redes de Trata fortaleciéndose en todo el territorio.

\subsection{EUROPA}

A Europa, em especial a centro-ocidental, tem grande preocupação com o tráfico de pessoas, pois é conhecida como local de destino para a exploração sexual e a prostituição de pessoas traficadas. O TIP Report $2011^{234}$, elaborado pelo governo norte-americano, classifica a grande maioria dos países da Europa ocidental como tier 1, ou seja, atendem a um standard mínimo no enfrentamento ao tráfico. Os países do leste europeu, embora enfrentem problemas gravíssimos relacionados ao tráfico sexual, aparecem com tier 2, com poucas exceções. Coincidentemente - pensando na relação entre os dois países - uma delas é a Rússia, com tier 2 watch list, conforme mapa abaixo.

\footnotetext{
${ }^{231}$ NIREMPERGER e RONDAN, op. cit., p. 65-66.

${ }^{232}$ BAUCHÉ, op. cit., p. 41.

${ }^{233}$ FLORENCIA ONASSIS, op. cit., p. 160.

${ }^{234}$ Disponível em: <http://www.state.gov/g/tip/rls/tiprpt/2011/>.
} 
Mapa 2 - Europa (Tier Placements - TIP Repor 2011) ${ }^{235}$

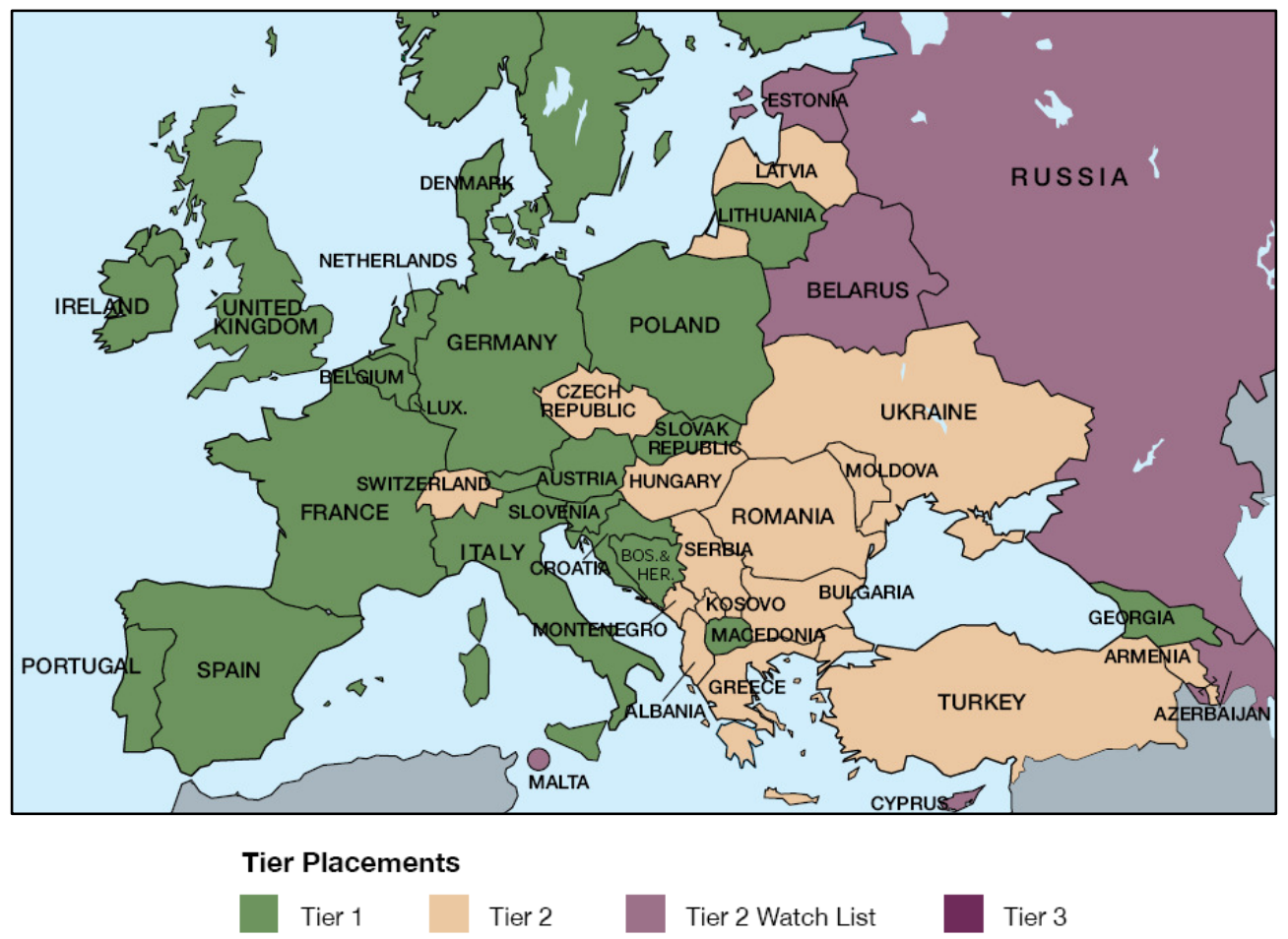

Segundo o Relatório ${ }^{236}$ da Convenção do Conselho da Europa sobre a Luta contra o Tráfico de Seres Humanos, de 2005, conhecida como Convenção de Varsóvia, o tráfico aparece como maior problema do Velho Continente. O Conselho da Europa - COE considera o tráfico de pessoas uma violação dos direitos humanos e uma ofensa à dignidade e à integridade do ser humano. Dessa forma, a Europa tem como prioridade a prevenção e o combate a esse fenômeno.

\subsubsection{Alemanha}

O Código Penal do Reich, de 1871, dispunha em sua seção 13 sobre os crimes contra a moralidade. Esse Código perdurou inclusive durante o regime nazista, pautado no direito penal do autor. Como exemplo desse período, podemos destacar o tratamento dado aos homossexuais, que eram enviados aos campos de concentração simplesmente por essa condição pessoal.

\footnotetext{
${ }^{235}$ Disponível em: <http://www.state.gov/g/tip/rls/tiprpt/2011/>.

${ }^{236}$ Disponível em: <http://www.coe.int/t/dg2/trafficking/campaign/Source/PDF_Conv197_Portuguese.pdf>. Acesso em: 1 nov. 2011.
} 
No pós-guerra a reforma penal se mostrava necessária. Em 1952 tiveram início as primeiras perspectivas de reforma, culminado uma década depois em um projeto do governo, sem, contudo, inovar. De caráter conservador, propugnava a normatização criminal da moralidade sexual.

Em oposição a esse modelo, um grupo de jovens penalistas publicou o denominado Projeto Alternativo, com aspectos liberalizantes, em especial no direito penal sexual. Esse ideário culminou, em 1969, na $1^{\text {a }}$ Lei de Reforma Penal, que descriminalizou a homossexualidade entre adultos, a sodomia e a difusão de pornografia. Sucessivas reformas aconteceram. Podemos citar a de 1975, que resultou na Nova Parte Geral do Código, e a $6^{\text {a }}$ Lei de Reforma Penal, de 1998, que dispôs sobre os crimes sexuais ${ }^{237}$.

Em 2005 ocorreram alterações nos crimes contra a liberdade (Freiheitsdelikten), que interessam diretamente a este estudo. $\mathrm{Na}$ esteira do Protocolo de Palermo, o legislador alemão fez adaptações ao delito de tráfico de pessoas para incluir, além da exploração sexual, também a laboral.

O Código Penal alemão possui uma seção específica para tutelar os crimes contra a liberdade. Nessa seção, de número $18^{\circ}$, estão inseridos os delitos de tráfico de seres humanos para fim de exploração sexual ${ }^{238}$, no $§ 232$, e sobre o tráfico de seres humanos para exploração laboral ${ }^{239}$, no $§ 233$.

Há uma discussão na doutrina alemã ${ }^{240}$ sobre a melhor localização sistêmica do delito previsto no $§ 232$. Não é pacífico se o principal bem jurídico a ser tutelado é a liberdade. Alguns autores entendem que o mais apropriado seria a autodeterminação sexual.

A pena-base do tráfico de pessoas para fim de exploração sexual é a prisão, de 6 meses a 10 anos, para aquele que tira proveito de uma situação de vulnerabilidade da

${ }^{237}$ SILVEIRA, Renato de Mello Jorge. Crimes sexuais: bases críticas para a reforma do direito penal sexual, p. $47-50$.

${ }_{238}$ Menschenhandel zum Zweck der sexuellen Ausbeutung.

${ }^{239}$ Menschenhandel zum Zweck der Ausbeutung der Arbeitskraft.

240 Nesse sentido: WHITE, Andrew; SCHMALFUSS, Conny; BRAUN, Sebastian. Strafbarkeit des Menschenhandels nach der Neuregelung der $\$ \S 232$ ff. StGB. Disponível em: $<$ http://docs.google.com/viewer?a=v\&q=cache:3m_9ZGI2UGkJ:heinrich.rewi.huberlin.de/Kriminalpolitisch es\%2520Forum/Menschenhandel.pdf>. Acesso em: 16 mar. 2011. 
vítima, ou quando esta é menor de 21 anos. A doutrina alemã se mostra contrária à fixação da idade de 21 anos como marco para a validade do consentimento. No entendimento majoritário, a idade de 18 anos já seria suficiente ${ }^{241}$.

Nos demais casos, envolvendo violência ou crianças (menores de 14 anos, conforme $§ 176$ Abs. 1), por exemplo, a pena pode variar de 1 a 10 anos de prisão.

No tráfico de pessoas para exploração laboral a pena-base, prevista no caput, também é a de prisão, de 6 meses a 10 anos, para aquele que abusa de situação de vulnerabilidade para traficar pessoa com o fim de escravidão ou servidão, inclusive por dívida.

\subsubsection{Espanha}

A legislação penal sexual espanhola, assim como a do Brasil, tutelava a honestidade como bem jurídico. Com o advento da reforma de 1989, passou a tutelar a liberdade sexual, bem jurídico corroborado pelo novo Código Penal espanhol, de $1995^{242}$.

Para acompanhar as mudanças sociais, a legislação espanhola sofreu profundas alterações na última década em sede de crimes sexuais, inclusive na legislação referente ao tráfico de pessoas.

Segundo Paz Lloria García ${ }^{243}$, o fenômeno do tráfico de seres humanos (trata de seres humanos ou trafficking of human beings), conhecido como a escravidão do século XXI, constitui uma das formas mais graves de atentar contra a dignidade das pessoas. Para a autora, o tráfico (la trata) constitui uma forma de escravidão, na medida em que o traslado de pessoas de um lugar para outro se dá sem o consentimento da vítima, ou com consentimento viciado, e sempre com a finalidade de exploração.

\footnotetext{
${ }^{241}$ Nesse sentido: WHITE, Andrew; SCHMALFUSS, Conny; BRAUN, Sebastian, op. cit.: "Unbefriedigend ist auch die Festsetzung der Schutzaltersgrenze auf 21 Jahre. [...] Die im Rahmenbeschluss geforderte Altersgrenze von 18 Jahre wären somit ausreichend und besser gewesen".

${ }^{242}$ SILVEIRA, op. cit., p. 54.

${ }^{243}$ BOIX REIG, Javier (dir.). Derecho penal: parte especial, p. 293.
} 
Uma peculiaridade dos países de língua espanhola é a utilização do vocábulo trata para designar o tráfico com fim de exploração ${ }^{244}$. Do verbo tratar, a palavra tem o significado de "manejar algo y usarlo materialmente", conforme o Dicionário da Real Academia Espanhola ${ }^{245}$. A palavra tráfico é utilizada para definir o tráfico de migrantes ilegais (em inglês, smuggling).

Em 2003, a Lei Orgânica n. 11 alterou sensivelmente a legislação referente ao tráfico, tendo sido muito criticada por misturar os conceitos de tráfico de pessoas e contrabando de migrantes ${ }^{246}$. Segundo Pérez Alonso, essa legislação pecava pelo excesso na luta contra a imigração clandestina e por omissão no enfrentamento ao tráfico de $\operatorname{pessoas}^{247}$.

Em 2010, o Código Penal espanhol sofreu grande alteração pela Lei Orgânica n. 5, e o legislador buscou superar essa questão, separando os conceitos de tráfico de pessoas para fim de exploração e tráfico ilegal de migrantes. A modificação visa adequar o diploma espanhol aos acordos internacionais dos quais o País é signatário, em especial à Decisión Marco Del Consejo 2002/629/JAI (DOCE n. 203, de 1-8-2002) ${ }^{248}$.

A Lei Orgânica n. 5, de 2010, incluiu um novo Título no Código Penal espanhol: Título VII, bis - De la trata de seres humanos, onde se encontra o art. 177, bis, itens 1 a 11, que dispõe sobre o tráfico de pessoas nos moldes do Protocolo de Palermo, incluindo a exploração sexual, do trabalho e a extração ou comercialização de órgãos.

\footnotetext{
${ }^{244}$ Para Serrano Gomes e Serrano Maíllo, Derecho penal: parte especial, p. 208, o termo "trata" é mais apropriado para a exploração do tipo sexual.

${ }^{245}$ Disponível em: <http://www.rae.es>.

${ }^{246}$ Segundo Carolina Villacampa Estiarte, a redação dada em 2003 ao art. 318, bis, do Código Penal espanhol refletia "una confusión de los conceptos 'trata de seres humanos' e 'inmigración clandestina', suficientemente determinados en la normativa comunitária". In: VILLACAMPA ESTIARTE, Carolina. Consideraciones acerca de la reciente modificación del delito de tráfico de personas. Revista Penal, p. 207.

No mesmo sentido, para Herminio Padilla Alba, a modificação do art. 318, bis, do Código Penal espanhol confundia tráfico de pessoas com imigração clandestina. In: El delito de tráfico ilegal de personas tras su reforma por la LO 11/2003, de 29 de septiembre. La Ley Penal: revista de derecho penal, procesal y penitenciario, p. 12.

${ }^{247}$ PÉREZ ALONSO, Esteban J. Consideraciones político-criminales sobre el fenómeno migratorio actual y el tráfico de personas. In: MIR PUIG, Santiago; CORCOY BIDASOLO, Mirentxu (dir.). Protección penal de los derechos de los trabajadores: seguridad en el trabajo, tráfico ilegal de personas e inmigración clandestina, p. 413.

${ }^{248}$ BOIX REIG (dir.), op. cit., p. 294, e SERRANO GÓMEZ e SERRANO MAÍLLO, op. cit., p. 207.
} 
Em que pese a evolução legislativa, esta não ficou isenta de censura ${ }^{249}$, pois o legislador espanhol fez uma transposição praticamente acrítica das recomendações internacionais, sem levar em conta as especificidades e necessidades do País. Um dos pontos destacados por Paz Lloria García ${ }^{250}$ é o fato de a fórmula legal se apresentar imprecisa e excessivamente ampla. Com a abundância de verbos típicos, atos de colaboração ou participação se elevam à categoria de autoria. A autora também menciona a inconveniência da definição numerus clausus deixar de fora alguma outra conduta que poderia constituir tráfico de pessoas. A finalidade do tráfico, também prevista em numerus clausus, afasta condutas como a imposição de um matrimônio forçado ou o fim de realização de testes clínicos com a vítima ${ }^{251}$, por exemplo.

Nos termos da exposição de motivos da citada lei, esse dispositivo visa à proteção da dignidade e da liberdade das vítimas. Afirma também que o delito abarca todas as formas de tráfico de seres humanos, nacional ou transnacional, relacionadas ou não com o crime organizado. O sujeito passivo pode ser espanhol ou estrangeiro.

A pena para o crime, na forma do art. 177, bis, $1^{252}$, é de 5 a 8 anos de prisão. Entre os itens 4 e 7 desse artigo estão previstas as causas de aumento de pena, como a situação

${ }^{249}$ BOIX REIG, Javier (dir.), op. cit., p. 299.

${ }^{250}$ Idem, p. 299.

${ }^{251}$ Idem, p. 302. Cabe aqui a observação de que as condutas mencionadas podem enquadrar-se na escravidão ou práticas similares (art. 177, bis, 1, a), dependendo das condições em que se procedam.

252 "Art. 177, bis, 1. Será castigado con la pena de cinco a ocho años de prisión como reo de trata de seres humanos el que, sea en territorio español, sea desde España, en tránsito o con destino a ella, empleando violencia, intimidación o engaño, o abusando de una situación de superioridad o de necesidad o de vulnerabilidad de la víctima nacional o extranjera, la captare, transportare, trasladare, acogiere, recibiere o la alojare con cualquiera de las finalidades siguientes:

a) La imposición de trabajo o servicios forzados, la esclavitud o prácticas similares a la esclavitud o a la servidumbre o a la mendicidad.

b) La explotación sexual, incluida la pornografía.

c) La extracción de sus órganos corporales

2. Aun cuando no se recurra a ninguno de los medios enunciados en el apartado anterior, se considerará trata de seres humanos cualquiera de las acciones indicadas en el apartado anterior cuando se llevare a cabo respecto de menores de edad con fines de explotación.

3. El consentimiento de una víctima de trata de seres humanos será irrelevante cuando se haya recurrido a alguno de los medios indicados en el apartado primero de este artículo. [...]

9. En todo caso, las penas previstas en este artículo se impondrán sin perjuicio de las que correspondan, en su caso, por el delito del artículo 318 bis de este Código y demás delitos efectivamente cometidos, incluidos los constitutivos de la correspondiente explotación. [...]

11. Sin perjuicio de la aplicación de las reglas generales de este Código, la víctima de trata de seres humanos quedará exenta de pena por las infracciones penales que haya cometido en la situación de explotación sufrida, siempre que su participación en ellas haya sido consecuencia directa de la situación de violencia, intimidación, engaño o abuso a que haya sido sometida y que exista una adecuada proporcionalidad entre dicha situación y el hecho criminal realizado" (excertos, grifos nossos). 
pessoal do sujeito passivo (menor de 18 anos ou incapaz), ou a participação do sujeito ativo em organização criminosa.

Uma questão muito relevante é a exigência, para a caracterização do delito, do emprego de violência, ameaça ou fraude, abuso de uma situação de superioridade ou de necessidade, ou da vulnerabilidade da vítima (art. 177, bis, 3).

Não se tratando de menor, e ausentes os meios indicados acima, o consentimento é válido, nos termos do Protocolo de Palermo. A falta de consentimento válido do sujeito passivo constitui o elemento central na hora de reconhecer um caso de tráfico de pessoas e diferenciá-lo do contrabando de migrantes ${ }^{253}$.

No caso específico do tráfico para fim de exploração sexual, deve-se incluir exclusivamente a prostituição forçada, ficando fora do âmbito desse delito o contrabando de migrante para o exercício voluntário da prostituição, para o qual existem tipos específicos $^{254}$.

O item 8 do art. 177, bis, dispõe sobre a punição de forma atenuada dos atos preparatórios, como incitamento, conspiração ou proposição para cometer o delito. Segundo Paz Lloria García ${ }^{255}$, a previsão justifica-se pela gravidade das condutas de tráfico.

Segundo o item 9 do referido artigo, as penas previstas para o tráfico de pessoas se aplicam sem prejuízo das correspondentes pelo delito de migração clandestina (art. 318, bis) bem como as referentes às respectivas modalidades de exploração. $\mathrm{O}$ delito se consuma com a conduta típica de aliciar, transportar etc., com a finalidade de exploração sexual, do trabalho ou de extração de órgãos. Se ocorrer efetivamente a exploração, haverá concurso de crimes ${ }^{256}$.

\footnotetext{
${ }^{253}$ BOIX REIG (dir.), op. cit., p. 303.

${ }^{254}$ Idem, p. 303. Os tipos mencionados encontram-se nos títulos referentes aos "ciudadanos extranjeros" ou "la libertad o indemnidad sexual".

${ }^{255}$ BOIX REIG (dir.), op. cit., p. 307.

${ }^{256}$ SERRANO GÓMEZ e SERRANO MAÍlLLO, op. cit., p. 208.
} 
$\mathrm{O}$ art. 318, bis, trata da migração clandestina, incluída no Título referente aos delitos contra os direitos dos cidadãos estrangeiros. Esse crime sempre terá caráter transnacional, predominando a defesa dos interesses do Estado no controle dos fluxos migratórios. Segundo Paz Lloria García ${ }^{257}$, no tráfico ilícito de migrantes (conhecido como smuggling of migrants) a conduta consiste em um movimento organizado de pessoas de um país a outro, com finalidade de lucro, rompendo-se a relação entre traficante e migrante quando atingido o propósito de fazer este último chegar ao local de destino, onde espera encontrar uma vida melhor.

O item 10 do art. 177, bis, dispõe sobre a reincidência internacional. Ou seja, a condenação por juízos ou tribunais estrangeiros por delitos da mesma natureza se equipara a uma condenação espanhola para fins de reincidência.

A vítima do tráfico, nos termos do art. 177, bis, 11, é isenta de pena pelas infrações criminais que tenha cometido sob a condição de exploração sempre que sua participação tenha sido consequência direta da situação de violência, intimidação etc. a que esteja submetida, e desde que haja proporcionalidade entre a situação e o crime. Trata-se de uma escusa absolutória. Vale mencionar que a proteção à vítima é uma das premissas do Protocolo de Palermo.

O art. 177, bis, não menciona a punição do "cliente", aquele que usufrui do serviço sexual da pessoa explorada.

\subsubsection{Itália}

A legislação penal italiana sempre influenciou a brasileira, como aconteceu com o Código de Zanardelli, de 1889, que dispunha sobre os delitos contra os bons costumes e a ordem nas famílias, e o Código de Rocco, de 1930, que tratava dos crimes contra a moralidade pública e os bons costumes.

${ }^{257}$ BOIX REIG (dir.), op. cit., p. 293-294. 
A mudança de paradigma nas questões sexuais a partir da década de 1960 exigia renovação. Apenas em 1996, embora criticada, foi aprovada no País a nova lei sobre violência sexual, pautada na noção de liberdade sexual. Em 1998 outra lei foi aprovada, agora referente a questões sexuais envolvendo menores de idade ${ }^{258}$.

Em 2003, a Lei n. 228 alterou os arts. 600, 601 e 602 do Código Penal italiano, referente ao tráfico de pessoas, que proporcionou instrumento mais adequado para o combate ao fenômeno. O novel diploma também criou o Fundo de Medidas Antitráfico e um programa especial de assistência para as vítimas desse crime ${ }^{259}$.

Neste passo, é importante mencionar que a expressão "traffico internazionale di persone" abrange duas situações diversas: o contrabando de migrantes (contrabbando di migranti ou smuggling of migrants), que consiste no favorecimento da imigração clandestina; e o tráfico de pessoas com a finalidade de exploração (tratta di persone ou trafficking in human beings) ${ }^{260}$. A seguir se analisará este último.

Calzaretti, Carabellese e Catanesi ${ }^{261}$ afirmam que, a partir da segunda metade da década de 90, o tráfico de seres humanos começou a ter progressiva relevância política na Itália, relacionada ao aumento da pressão migratória dos países mais pobres, como os africanos, latino-americanos, leste-europeus, asiáticos e os do Oriente Médio. Segundo os autores, o tráfico de pessoas exige uma análise multidisciplinar, que envolve a problemática da migração, a ação das organizações criminosas, além da forma assumida pelo mercado global do sexo.

O número de delitos envolvendo a prostituição na Itália aumentou de 1.192 casos em 1990 para 3.004 em 2001. Esse aumento refere-se à entrada de estrangeiras no mercado italiano. Segundo estimativas, no ano de 2004 o número de prostitutas na Itália era de 70.000. Dessas, metade trabalhava nas ruas e a outra metade em bordéis, clubes etc. Das prostitutas que trabalhavam nas ruas, 90\% eram estrangeiras, e destas 54\% vinham da Nigéria, 30\% do leste europeu (Albânia, Moldávia, Rússia, Ucrânia, Romênia e Bulgária) e

\footnotetext{
${ }^{258}$ SILVEIRA, op. cit., p. 56-57.

${ }^{259}$ CALZARETTI, Cinzia; CARABELLESE, Felice; CATANESI, Roberto. Il traffico di donne finalizzato allo sfruttamento della prostituzione in Italia. Rassegna Italiana di Criminologia, Milano, v. 16, n. 4, p. 648.

${ }^{260}$ Idem, p. 643-644.

${ }^{261}$ Idem, p. 642-643.
} 
16\% da América Latina. Desse montante, estima-se que de 2.000 a 3.000 mulheres eram vítimas de tráfico, vivendo em regime de escravidão ${ }^{262}$.

O art. 601 do Código Penal italiano dispõe especificamente sobre o crime de tráfico de pessoas $^{263}$, diretamente relacionado aos delitos do art. 600, que trata da redução ou manutenção de alguém em condição de escravidão ou servidão, e aos do art. 602, que trata da compra e venda de escravos. Esses artigos encontram-se no Capítulo III - Dos delitos contra a liberdade individual.

O crime previsto no art. 601 do Código Penal italiano pune com prisão de 8 a 20 anos aquele que pratica tráfico de pessoa, ou seja, a conduta de induzir ou constranger alguém a entrar, permanecer ou deixar o território italiano, ou mover-se dentro dele, desde que a vítima encontre-se nas condições referidas no art. 600, ou com a finalidade de cometer os crimes previstos no referido artigo.

Nos termos do art. 601, a indução se dá mediante engano, e o constrangimento, mediante violência, ameaça, abuso de autoridade ou se valendo da condição de inferioridade física ou psíquica, ou de uma situação de vulnerabilidade, ou mediante promessa de pagamento ou outra vantagem àquele que tem autoridade sobre a vítima.

O art. 600 do Código italiano tipifica a redução ou manutenção em escravidão ou servidão, punindo com prisão de 8 a 20 anos aquele que exerce sobre uma pessoa poderes correspondentes ao direito de propriedade, ou que mantém ou reduz uma pessoa em um estado contínuo de sujeição, constrangendo-a à prestação de trabalho, inclusive de natureza sexual ou mendicância, ou a outra forma de exploração.

\footnotetext{
${ }^{262}$ CALZARETTI, CARABELLESE e CATANESI, op. cit., p. 652-653.

263 "Art. 601. Tratta di persone.

Chiunque commette tratta di persona che si trova nelle condizioni di cui all'articolo 600 ovvero, al fine di commettere i delitti di cui al primo comma del medesimo articolo, la induce mediante inganno o la costringe mediante violenza, minaccia, abuso di autorità o approfittamento di una situazione di inferiorità fisica $o$ psichica o di una situazione di necessità, o mediante promessa o dazione di somme di denaro o di altri vantaggi alla persona che su di essa ha autorità, a fare ingresso o a soggiornare o a uscire dal territorio dello Stato o a trasferirsi al suo interno, è punito con la reclusione da otto a venti anni. La pena è aumentata da un terzo alla metà se i delitti di cui al presente articolo sono commessi in danno di minore degli anni diciotto o sono diretti allo sfruttamento della prostituzione o al fine di sottoporre la persona offesa al prelievo di organi". (grifos nossos)
} 
A pena é aumentada de um terço à metade se os crimes referidos nos arts. 600 e 601 forem cometidos contra menores de 18 anos ou tiverem como finalidade a exploração da prostituição ou a remoção de órgãos.

\subsubsection{Portugal}

Até o advento do Código Penal de 1982, a legislação portuguesa sobre direito penal sexual sempre esteve arraigada em valores morais e religiosos. O Código vigente, no entanto, já trouxe questões discutidas no projeto alternativo alemão dos anos $60^{264}$. Segundo Jorge de Figueiredo Dias ${ }^{265}$, a reforma de 1995 parte do princípio de que não deve ser punível qualquer conduta sexual praticada em lugar privado e entre adultos que nela consentem.

Com o intuito de adaptar-se às modificações sociais das últimas três décadas, o Código Penal português sofreu sucessivas alterações ${ }^{266}$ no tocante ao crime de tráfico de pessoas. Antes da reforma de 2007, o tráfico de pessoas era tipificado no art. 169 - Crimes contra a liberdade sexual ${ }^{267}$.

As condutas descritas deveriam dar-se através de um meio típico - violência, ameaça grave, ardil, manobra fraudulenta, abuso de autoridade ou aproveitamento de situação de vulnerabilidade -, dirigido à prática da prostituição ou de atos sexuais de relevo no exterior. Exigia-se o dolo específico e a efetiva prática da prostituição ou de atos sexuais de relevo ${ }^{268}$ para a consumação do crime ${ }^{269}$.

\footnotetext{
${ }^{264}$ SILVEIRA, op. cit., p. 50-51.

${ }^{265}$ DIAS, Jorge de Figueiredo. Direito penal: parte geral, p. 113.

${ }^{266}$ Nos anos de 1995, 1998, 2001 e 2007. In: NEVES, João Ataíde das. Avançar no combate ao tráfico de seres humanos. Revista Sub Judice - Justiça e Sociedade, p. 39-40.

267 "Art. $169^{\circ}$ (Tráfico de pessoas) Quem, por meio de violência, ameaça grave, ardil, manobra fraudulenta, abuso de autoridade resultante de uma relação de dependência hierárquica, econômica ou de trabalho, ou aproveitando qualquer situação de especial vulnerabilidade, aliciar, transportar, proceder ao alojamento ou acolhimento de pessoa, ou propiciar as condições para a prática por essa pessoa, em país estrangeiro, de prostituição ou de actos sexuais de relevo, é punido com prisão de 2 a 8 anos.".

268 "Acto sexual de relevo é todo aquele que assume uma natureza ou significado directamente relacionado com a esfera da sexualidade de quem o sofre ou pratica, que pela sua gravidade contende com a liberdade de determinação sexual da vítima”. TRT, Portugal, recurso penal n. 7/06.4TAVNO.C3, 24-6-2009.

${ }^{269}$ DIAS, Jorge de Figueiredo (dir.). Comentário Conimbricense do Código Penal: Parte Especial, p. 511.
} 
A Lei n. 59/2007 fez alterações profundas no Código português. A reforma de 2007 se deu em atendimento à Convenção de Varsóvia do Conselho da Europa e ao Protocolo de Palermo. O art. 160 do Capítulo IV - Dos crimes contra a liberdade pessoal ${ }^{270}$ passou a tratar do tráfico de pessoas abrangendo a exploração sexual ou do trabalho, e a extração de órgãos. A pena, na forma do caput, é de prisão, de 3 a 10 anos.

Dois pontos são muito relevantes no tocante ao dispositivo em tela: o consentimento e o "cliente".

Assim, como na legislação espanhola, se não houver alguma das formas de violência, fraude ou abuso previstas na lei, e não se tratar de menor ou pessoa vulnerável, o consentimento será válido.

Quanto ao "cliente", o item 5 do art. 160 criminaliza a conduta daquele que, tendo conhecimento do crime de tráfico, utiliza os serviços ou os órgãos da vítima. A pena é de prisão de 1 a 5 anos, se não decorrer de sua conduta pena mais grave. Trata-se de uma inovação legislativa ${ }^{271}$, nos termos no art. 19 da já referida Convenção de Varsóvia, de 2005, que dispõe sobre a criminalização do uso dos serviços da vítima de tráfico.

270 “Art. $160^{\circ}$ (Tráfico de pessoas)

1 - Quem oferecer, entregar, aliciar, aceitar, transportar, alojar ou acolher pessoa para fins de exploração sexual, exploração do trabalho ou extracção de órgãos:

a) Por meio de violência, rapto ou ameaça grave;

b) Através de ardil ou manobra fraudulenta;

c) Com abuso de autoridade resultante de uma relação de dependência hierárquica, económica, de trabalho ou familiar;

d) Aproveitando-se de incapacidade psíquica ou de situação de especial vulnerabilidade da vítima; ou

e) Mediante a obtenção do consentimento da pessoa que tem o controlo sobre a vítima; é punido com pena de prisão de três a dez anos.

2 - A mesma pena é aplicada a quem, por qualquer meio, aliciar, transportar, proceder ao alojamento ou acolhimento de menor, ou o entregar, oferecer ou aceitar, para fins de exploração sexual, exploração do trabalho ou extracção de órgãos.

3 - No caso previsto no número anterior, se o agente utilizar qualquer dos meios previstos nas alíneas do $\mathrm{n}$. 1 ou actuar profissionalmente ou com intenção lucrativa, é punido com pena de prisão de três a doze anos.

4 - Quem, mediante pagamento ou outra contrapartida, oferecer, entregar, solicitar ou aceitar menor, ou obtiver ou prestar consentimento na sua adopção, é punido com pena de prisão de um a cinco anos.

5 - Quem, tendo conhecimento da prática de crime previsto nos n. 1 e 2, utilizar os serviços ou órgãos da vítima é punido com pena de prisão de um a cinco anos, se pena mais grave lhe não couber por força de outra disposição legal.

6 - Quem retiver, ocultar, danificar ou destruir documentos de identificação ou de viagem de pessoa vítima de crime previsto nos n. 1 e 2 é punido com pena de prisão até três anos, se pena mais grave lhe não couber por força de outra disposição legal" (grifos nossos).

${ }^{271}$ PATTO, Pedro Maria Godinho Vaz. O crime de tráfico de pessoas no Código Penal revisto: análise de algumas questões. Disponível em <http://www.cej.mj.pt/cej/home/home.php>. Acesso em: 15 nov. 2010. 
Cabe trazer a lume uma crítica de Paulo de Sousa Mendes ${ }^{272}$, que dispõe que o novo tipo legal deverá acarretar dificuldades interpretativas, em especial sua distinção e autonomização diante de outras figuras penalmente relevantes, como o auxílio à migração ilegal (art. $183^{\circ}$ da Lei da Imigração).

\section{4 ÁFRICA E ÁSIA}

O tráfico de pessoas é um problema gravíssimo, que assola todo o continente asiático. Países como Nepal, Camboja, Índia e Tailândia convivem - muitas vezes pacificamente - com o total desrespeito aos direitos humanos de suas meninas e mulheres, e também de meninos, em menor número.

A África, por sua vez, sofre incontáveis mazelas, e dentre elas o tráfico de pessoas para todas as finalidades de exploração, seja a sexual, para trabalho escravo, ou extração de órgãos (utilizados para transplante ou para cerimônias e rituais ${ }^{273}$ ). A miséria, as guerras civis, a discriminação de gênero, etnia e religião, além de governos totalitários, fazem do continente um ambiente fértil para o crime em comento. $\mathrm{O}$ tráfico sexual, seja de maiores ou menores, ocorre dentro dos países, entre os países do continente, e para a Europa, Ásia e Oriente Médio.

Segundo dados do UNICEF ${ }^{274}$ a maior preocupação do continente africano é o tráfico de menores. As plantações de cacau da Costa do Marfim são conhecidas pela utilização de trabalho escravo infantil; a exploração de meninos soldados é prática nas constantes guerras civis, como em Serra Leoa ${ }^{275}$ etc.

\footnotetext{
${ }^{272}$ MENDES, Paulo de Sousa. Tráfico de pessoas. In: Jornadas sobre a Revisão do Código Penal - 27 e 28 de Setembro de 2007 - Centro de Estudos Judiciários. Disponível em: <http://www.estig.ipbeja.pt/ ac_direito/traficopessoassm.pdf.>. Acesso em: 14 nov. 2010.

${ }^{273}$ SERRA, Carlos (dir.). Tatá papá, tatá mamãa: tráfico de menores em Moçambique, p. 55.

${ }^{274}$ Disponível em: <http://www.unicef.pt/docs/pdf/04_04_23_trafico_de_seres_humanos_em_africa.pdf.>. Acesso em: 6 jan. 2012.

${ }^{275}$ Sobre o assunto, veja: BEAH, Ishmael. Muito longe de casa: memórias de um menino soldado.
} 
Na obra sobre tráfico de menores em Moçambique, essa preocupação fica evidenciada. Segundo Alexandre Baia ${ }^{276}$, o País vive um quadro de vulnerabilidade social e econômica, especialmente para crianças e adolescentes. A presença de crianças nas ruas, sem comida, afeto, proteção, ocupação, acompanhamento, proporciona o ambiente favorável para o crime de tráfico em todas as suas modalidades.

Marina Feferbaum ${ }^{277}$ afirma que é difícil sistematizar as questões atinentes aos direitos humanos na África em categorias bem definidas, pois diversos fatores concorrem para o quadro de cada país, havendo grande heterogeneidade. Alguns países se encontram em situação de "pré-direitos humanos", inexistindo condições mínimas para o exercício de qualquer tipo de liberdade. Pode-se citar casos de genocídio, como o acontecido em Ruanda em 1994, além dos crimes de guerra e casos de efetiva escravidão, com destaque para a violência sexual como prática comum.

Neste cenário é realmente difícil obter dados confiáveis, bem como vislumbrar políticas efetivas de enfrentamento ao tráfico de pessoas. Veja-se no mapa abaixo como o TIP Report 2011 se manifesta sobre os países africanos e asiáticos. Em alguns casos o Relatório chegou a considerar alguns países casos especiais, como a Costa do Marfim, com base na guerra civil ocorrida em 2010, e a Somália, tendo em vista a falta de um governo central viável desde 1991.

Mapa 3 - África e Ásia (Tier Placements - TIP Repor 2011) ${ }^{278}$

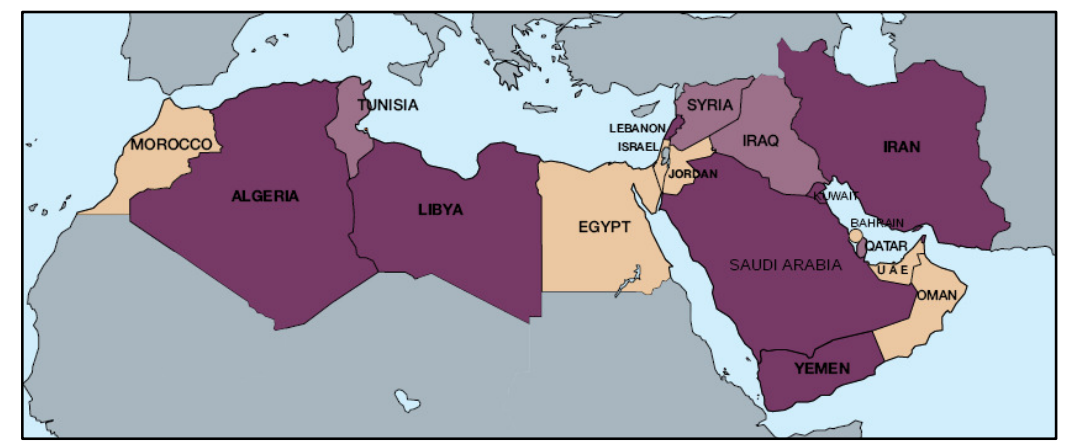

\footnotetext{
${ }^{276}$ BAIA, Alexandre. Desaparecimento ou tráfico de menores e extracção de órgãos humanos? (trabalho de campo em Nampula, Pemba e Tetê). In: SERRA, Carlos (dir.), op. cit., p. 227-228.

${ }^{277}$ FEFERBAUM, Marina. Proteção internacional dos direitos humanos: análise do sistema africano, p. 3640.

${ }^{278}$ Disponível em: <http://www.state.gov/g/tip/rls/tiprpt/2011/>.
} 

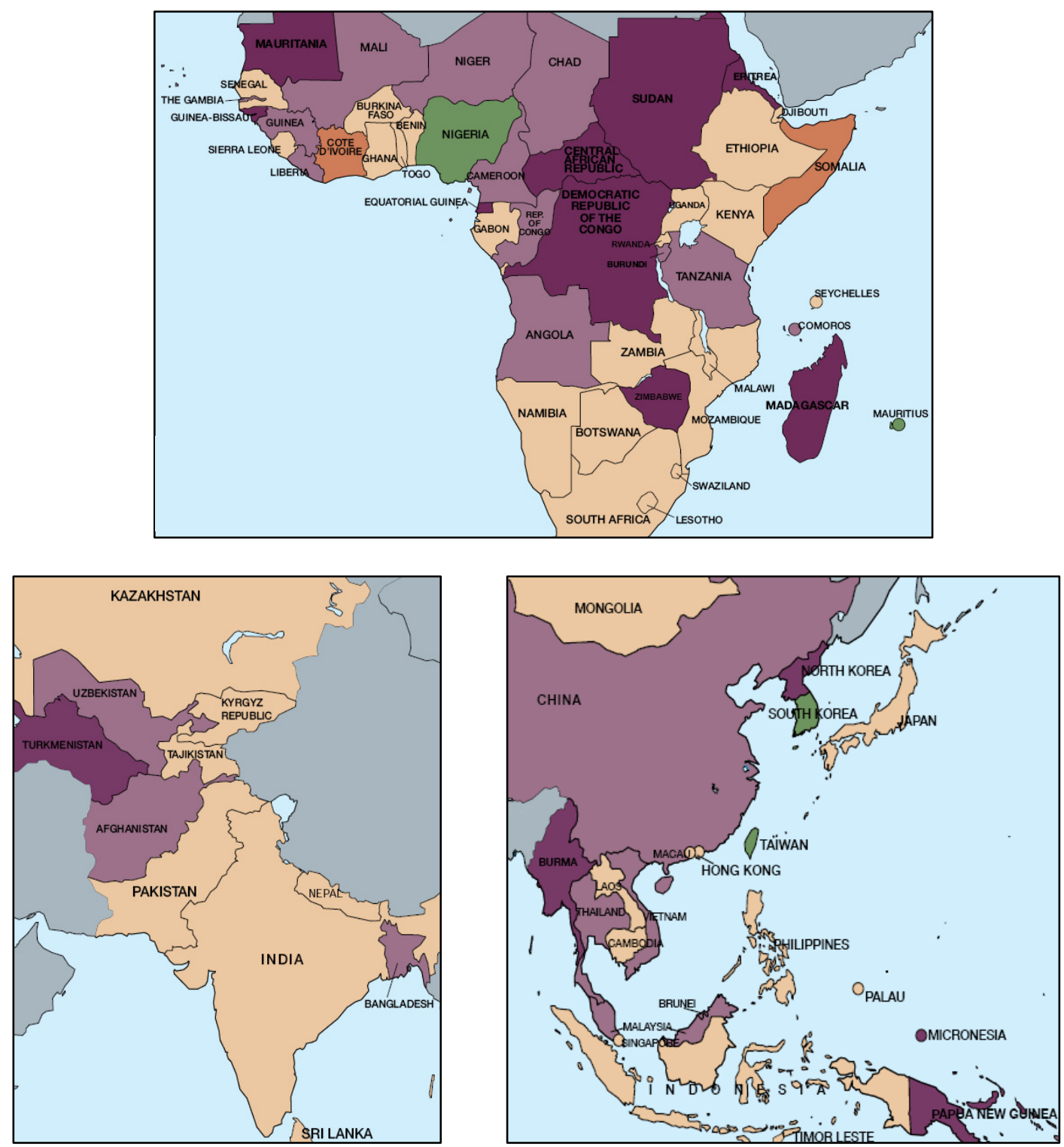

Tier Placements

\begin{tabular}{l|ll} 
Tier 1 & Tier 2
\end{tabular}

Tier 2 Watch List

Tier 3

Special Cases

A Nigéria ${ }^{279}$ foi o único país africano avaliado com tier 1 . Porém, mesmo com o esforço do governo, o Relatório apresenta um quadro preocupante. O país serve de origem, trânsito e destino para mulheres e crianças submetidas a trabalho forçado e tráfico sexual. As mulheres e meninas são recrutadas especialmente nas zonas rurais e traficadas internamente para exploração sexual e doméstica. Os meninos são aliciados para o trabalho forçado em pedreiras, minas, agricultura, venda ambulante, servidão doméstica, mendicância etc. Crianças de países da África ocidental, principalmente Benin, Togo e

${ }^{279}$ Disponível em: <http://www.state.gov/g/tip/rls/tiprpt/2011/164233.htm>. Acesso em: 6 jan. 2012. 
Gana, realizam trabalho forçado na Nigéria, e são submetidos a trabalhos perigosos como os das minas de granito. Há também o tráfico internacional para países da África ocidental e central, como o Gabão, Camarões, Gana, Chade, Benin, Togo, Níger, e também para a África do Sul. Foi também levantado durante a elaboração do Relatório que há um número significativo de mulheres nigerianas que vivem em situações de prostituição forçada no Mali e na Costa do Marfim. Mulheres e meninas nigerianas são levadas também para a Itália, Espanha, Holanda, Alemanha, Turquia, Bélgica, Dinamarca, França, Suécia, Suíça, Noruega, Irlanda, Grécia e Rússia para fim de exploração sexual. Em alguns casos são obrigados a atravessar o deserto a pé rumo a Europa (rota mediterrânea). Há ainda o tráfico para o Norte da África e para o Oriente Médio, incluindo Arábia Saudita, os Emirados Árabes Unidos, Líbano, Egito, Líbia e Marrocos, onde são mantidos em cativeiro no comércio do sexo ou em situações de trabalho forçado.

$\mathrm{Na}$ Ásia a história se repete. Os traficantes geralmente compram as meninas de famílias desesperadas e miseráveis em pequenos vilarejos, ou as levam com a promessa de trabalho em algum país vizinho - como o de vendedora de frutas ou lavadora de pratos, por exemplo. As garotas saem de suas casas e são vendidas a donos de bordéis, onde são forçadas a servir até mais de 20 homens por dia. Se tentarem fugir, são espancadas ou mortas como forma de exemplo. Caso consigam retornar as suas vilas, enfrentam outros problemas, como o estigma, a rejeição e a completa falta de oportunidade, o que muitas vezes as leva a serem retraficadas ${ }^{280}$.

Na Índia ${ }^{281}$ não é só a questão do tráfico que assusta. A prostituição de meninas é uma prática comum. Existem tribos - como os nutts - que se dedicam à prostituição intergeracional! No documentário Nascidos em Bordéis, de Zana Briski, a situação fica evidente: a única opção que se apresenta às filhas das prostitutas que atingem a puberdade é a prostituição.

Kara $^{282}$ discorre sobre visitas a Falkland Road e Kamathipura, grandes zona de meretrício em Mumbai, onde existem milhares de prostitutas. A presença de meninas do

\footnotetext{
${ }^{280}$ KARA, Siddharth. Researching the cruel world of sex trafficking in South Asia. Disponível em: $<$ http://thecnnfreedomproject.blogs.cnn.com/2011/09/29/researching-the-cruel-world-of-sex-trafficking-insouth-asia/>. Acesso em: 2 out. 2011.

${ }^{281}$ KRISTOF e WUDUNN, op. cit., p. 29.

${ }^{282}$ KARA, Siddharth. Sex trafficking: inside the business of modern slavery, p. 45-49.
} 
Nepal, Bangladesh e da própria Índia, vindas de outros estados, é muito comum nesses bordéis. Nesse cenário, com a evidente presença do tráfico e da escravidão sexual, meninas e mulheres sofrem todo tipo de violência. As meninas mencionadas por Kara apresentavam hematomas, cicatrizes e marcas de queimadura de cigarro, além da pela ressecada e suja. Segundo relatos de vítimas que conseguiram fugir para abrigos, todos os dias mulheres são torturadas, drogadas e assassinadas no mercado do sexo em Mumbai.

Segundo dados de um estudo nos bordéis indianos, de 2008, apresentados por Kristof e Wudunn ${ }^{283}$, a Índia é o país que mais tem escravas sexuais. Das prostitutas pesquisadas, indianas e nepalesas, cerca de $50 \%$ que começaram na adolescência foram coagidas a isso. As que iniciaram na prostituição com cerca de 20 anos o fizeram voluntariamente, como único meio para alimentar os filhos.

A questão do tráfico de pessoas entre os países asiáticos também reflete questões culturais e de gênero arraigados há séculos na sociedade. As meninas nepalesas que são traficadas para a Índia, por exemplo ${ }^{284}$, são vistas como pessoas de segunda classe, que têm a obrigação de cumprir esse mister, assim como eram vistos os negros nos séculos passados.

A rota mais intensa de tráfico sexual com destino à Índia é entre o Nepal e Mumbai, via Varanasi. Contudo, nenhum dos países se mostra empenhado em pôr um fim a essa realidade.

Na Índia, que é signatária do Protocolo de Palermo, a legislação utilizada no combate ao tráfico é de 1956, alterada em 1986 - Immoral Trafficking and Prevention Act (ITPA). Segundo Kara ${ }^{285}$, essa norma criminaliza os bordéis e os rufiões, mas eles são tolerados socialmente. E, mesmo quando a lei é aplicada, as penas são mínimas, de cerca

\footnotetext{
${ }^{283}$ KRISTOF e WUDUNN, op. cit., p. 31-32.

${ }^{284} \mathrm{O}$ jornalista americano Nicholas Kristof narra uma conversa entre ele e um guarda indiano na fronteira entre a Índia e o Nepal. Por essa fronteira passam muitas meninas nepalesas que são traficadas para a Índia a caminho dos bordéis de Calcutá. Kristof notou que os nepaleses ingressavam em território indiano livremente, ao passo que ele teve de preencher vários documentos para deixar o país. Ao questionar o guarda sobre a questão das meninas e mulheres traficadas, a resposta foi que eles não se preocupavam com elas, pois não poderiam fazer nada contra a prostituição. Para ele essas meninas - simples camponesas analfabetas, consideras seres de segunda classe - são traficadas para que possam ter harmonia na sociedade indiana, para proteger as boas moças e os homens poderem satisfazer-se sem importuná-las. In: KRISTOF e WUDUNN, Metade do céu, p. 49-50.

${ }^{285}$ KARA, op. cit., p. 78-79.
} 
de 3 anos de prisão e multa (US\$ 44). A lei nepalesa é de 1986, alterada em 1999 - The Human Trafficking Control and Punishment Act. Essa norma, embora mais rigorosa que a indiana, estabelecendo penas de até 20 anos de prisão e multa (US\$2.666), tem também pouca aplicação, sendo muito baixo o número de processos por ano. No Nepal existe uma unidade especial da polícia para cuidar do tráfico, mas conta com poucos oficiais, que também é responsável pelos demais crimes contra mulheres e crianças, o que dificulta muito um trabalho eficaz. A unidade policial responsável pelo tráfico de drogas é muito mais aparelhada e conta com um número bem maior de oficiais, o que demonstra que o enfrentamento ao tráfico de pessoas ainda não é uma prioridade no país ${ }^{286}$.

A Tailândia ${ }^{287}$, tier 2 watch list, no TIP Report 2011, aparece como país de origem, destino e trânsito para o crime de tráfico de pessoas, seja para o trabalho escravo ou exploração sexual. A maior parte das pessoas que são traficadas para o país vem de países vizinhos, como Birmânia e Camboja, mas também existem pessoas do Uzbequistão e de Fiji. Tailandeses traficados foram encontrados nos Emirados Árabes, Sri Lanka, China, Rússia, Reino Unido, Cingapura, Austrália, Canadá, Alemanha, Indonésia, Israel, Japão, Kuwait, Líbia, Malásia, Qatar, Arábia Saudita, África do Sul, Taiwan e Timor-Leste. Especificamente quanto ao tráfico sexual, o país serve como trânsito para norte-coreanas, chinesas, vietnamitas, paquistanesas e birmanesas rumo à Malásia, Indonésia, Cingapura, Rússia, Europa Ocidental, Coreia do Sul e Estados Unidos.

O país ${ }^{288}$ proíbe a prostituição. Porém, é um conhecido destino de turismo sexual, envolvendo especialmente crianças e adolescentes. A indústria do sexo se alastra por dance clubs, bordéis, saunas, bares, go-go clubs, casas de massagem, caraoquês etc. As estimativas para o número de prostitutas no país variam de 120 mil (dados do governo tailandês) a 2 milhões (dados de ONGs). O preço por uma semana com uma prostituta adolescente é de US\$125, o que torna o País um mercado muito atrativo para europeus e americanos. Assim como nos outros países mencionados, na Tailândia as questões de gênero são culturais, sendo o papel da mulher de total submissão na sociedade. Ou seja, não basta proibir condutas. É necessária uma mudança de paradigmas.

\footnotetext{
${ }^{286}$ KARA, op. cit., p. 79-80.

${ }^{287}$ Disponível em: <http://www.state.gov/g/tip/rls/tiprpt/2011/164233.htm>. Acesso em 1 jan. 2012.

${ }^{288}$ KARA, op. cit., p. 152-154. Segundo o autor, o país parece um gigante bordel com oferta ostensiva de serviços sexuais.
} 
Não se pode enxergar e julgar os países asiáticos e africanos com olhos ocidentais. As questões culturais devem ser respeitadas e preservadas. Contudo, quando essas condutas aviltam os direitos humanos, e suas vítimas agem sob coação ou violência, essas nações têm a obrigação de prevenir e punir esses atos de violência, e proteger essas pessoas, dando a elas oportunidades para uma vida digna, livre e saudável. 


\section{O TRÁFico INTERNACIONAL DE PESSOAS PARA FIM DE EXPLORAÇÃO SEXUAL NO BRASIL}

O tráfico internacional de pessoas para fim de exploração sexual é tutelado no Brasil pelo art. 231 do Código Penal, com as alterações da Lei n. 12.015/2009. Neste tópico proceder-se-á à análise doutrinária e crítica desse dispositivo, mencionando o entendimento jurisprudencial dominante, quando pertinente.

\subsection{EVOLUÇÃO LEGISLATIVA: DAS ORDENAÇÕES FILIPINAS À REFORMA PENAL DE 2009}

O tráfico de pessoas é tipo penal de recente criação, fruto da cooperação internacional sobre a matéria ${ }^{289}$. As Ordenações Filipinas e o Código Criminal do Império dispunham apenas sobre o lenocínio de forma ampla, sem mencionar o tráfico. Como o direito penal reflete o momento histórico de casa país, o legislador de outrora não via a necessidade de tutelar tal delito.

O Código Penal de 1890 foi o primeiro a contemplar esse delito, porém de forma equívoca. O dispositivo que tratava da matéria era o art. 278, localizado no Capítulo III Do lenocínio do Título VIII - Dos crimes contra a segurança da honra e honestidade das famílias e do ultraje público ao pudor:

Art. 278. Induzir mulheres, quer abusando de sua fraqueza ou miséria, quer constrangendo-as por intimidações ou ameaças a empregarem-se no tráfico da prostituição; prestar-lhes, por conta própria ou de outrem, sob sua ou alheia responsabilidade, assistência, habitação e auxílios, para auferir, direta ou indiretamente, lucros desta especulação:

Penas - de prisão celular por um a dois anos e multa de 500\$000 a 1:000\$000. (grifos nossos)

A expressão "Induzir mulheres [...] a empregarem-se no tráfico da prostituição" pode induzir a erro. Na verdade, quem se empregava no tráfico não era a mulher, que era a vítima ou objeto deste, mas sim o traficante ${ }^{290}$.

\footnotetext{
${ }^{289}$ FRAGOSO, Heleno Cláudio. Lições de direito penal, p. 529.

${ }^{290}$ Idem, p. 530.
} 
Esse dispositivo exige o abuso da situação de fraqueza ou miséria da mulher, ou o emprego de constrangimento para o exercício da prostituição. Assim, depreende-se que o consentimento poderia ser considerado válido.

A Lei n. 2.992, de 25-9-1915, conhecida com Lei Mello Franco, alterou a redação do art. $278^{291}$ do Código Penal de 1890 , passando o delito a ser tratado em seu $\S 1^{\text {o }}$, sem a utilização do vocábulo "tráfico". Além de aumentar a pena de prisão para o delito, de 1 a 2 anos para de 1 a 3 anos, essa lei é expressa na questão do consentimento, ignorado apenas no caso da menor. O texto foi ratificado pela Consolidação das Leis Penais de 1932.

O Código Penal de 1940 teve origem no Projeto de Alcântara Machado ${ }^{292}$. O texto aprovado se diferencia do projeto original porque este último admitia o homem e a mulher como vítimas do delito de tráfico.

O Código Penal de 1940 manteve sua redação original até o ano de 2005, quando foi alterado pela Lei n. 11.106. Em 2009 sofreu outra alteração, agora pela Lei n. 12.015. Veja-se a seguir um quadro comparativo com o texto original e o alterado do Código Penal, bem como as disposições correspondentes no Protocolo de Palermo.

\footnotetext{
291 “Art. 278. Manter ou explorar casas de tolerância, admitir na casa em que residir, pessoas de sexos diferentes, ou do mesmo sexo, que aí se reúnam para fins libidinosos; induzir mulheres, quer abusando de sua fraqueza ou miséria, quer constrangendo-as por intimidação ou ameaças a entregarem-se à prostituição; prestar, por conta própria ou de outrem, sob sua ou alheia responsabilidade, qualquer assistência ou auxílio ao comércio da prostituição:

Pena - de prisão celular por um a três anos e multa de 1:000\$ a 2:000\$000.

$\S 1^{\circ}$ Aliciar, atrair ou desencaminhar, para satisfazer as paixões lascivas de outrem, qualquer mulher menor, virgem ou não, mesmo com o seu consentimento; aliciar, atrair ou desencaminhar, para satisfazer às paixões lascivas de outrem, qualquer mulher maior, virgem ou não empregando para esse fim ameaça, violência, fraude, engano, abuso de poder ou qualquer outro meio de coação; reter, por qualquer dos meios acima referidos, ainda mesmo por causa de dívidas contraídas, qualquer mulher maior ou menor, virgem ou não, em casa de lenocínio, obrigá-la a entregar-se à prostituição: Pena - as do dispositivo anterior.

$\S 2^{\circ}$ Os crimes de que trata o art. 278 e $\S 1^{\circ}$ do mencionado artigo serão puníveis no Brasil ainda que um ou mais atos constitutivos das infrações neles previstas tenham sido praticados em país estrangeiro. [...]". (grifos nossos)

${ }^{292}$ NORONHA, E. Magalhães. Direito penal, p. 239-240.
} 


\section{Quadro 1 - O tráfico de pessoas no Código Penal e no Protocolo de Palermo}

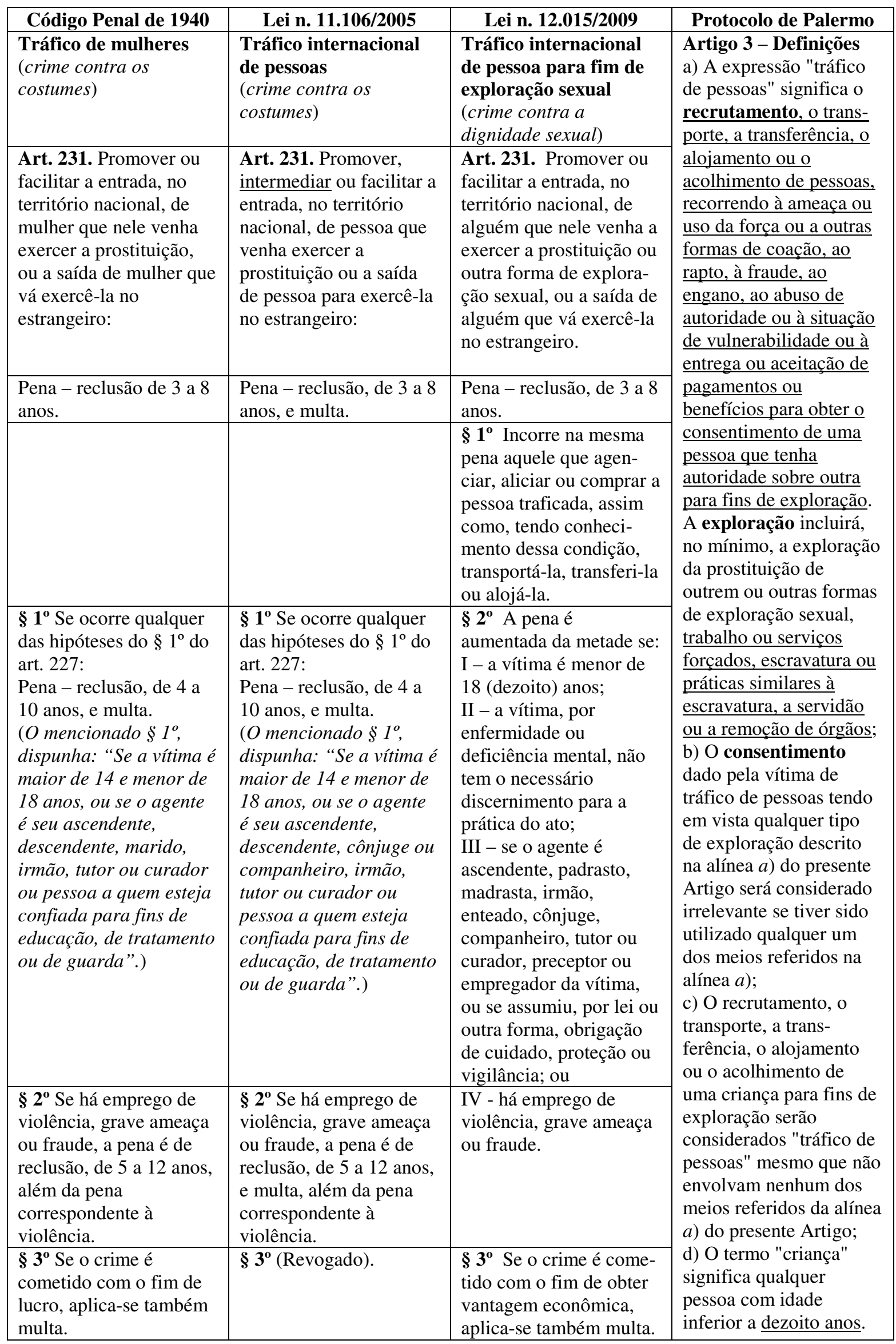


Avaliando o quadro acima, verificam-se quatro alterações mais relevantes ao longo das modificações ocorridas no art. 231 do Código Penal. A primeira é a modificação do sujeito passivo com o advento da Lei n. 11.106, de 2005 - de "mulher" passou a "pessoa". As outras são decorrentes da alteração de 2009, pela Lei n. 12.015. Foi acrescida a exploração sexual, além da prostituição, como finalidade do tráfico. A anterior qualificadora referente à vitima de 14 a 18 anos passou a ser uma causa de aumento de pena quando a vítima for menor de 18 anos, sem um limite mínimo de idade. Além disso, em 2009 o bem jurídico tutelado deixou de ser os costumes para ser a dignidade sexual.

Comparando o art. 231 do Código com o Protocolo de Palermo, duas diferenças saltam aos olhos: a questão do consentimento - ignorada na legislação pátria e admitida no Protocolo - e a abrangência do tráfico, que na legislação internacional inclui, além da finalidade de exploração sexual, o trabalho escravo e a remoção de órgãos. Ambas serão analisadas no Capítulo 5.

Muitas questões doutrinárias necessitam ser abordadas no tocante a esse delito. A primeira delas é a identificação do bem jurídico.

\subsection{BEM JURÍDICO TUTELADO}

Conforme dispõe Marco Antonio Marques da Silva ${ }^{293}$, o tráfico de pessoas e a escravatura resultam na violação dos mais elementares direitos da pessoa e no total desprezo pela dignidade humana. Mas, como delimitar esse bem jurídico?

A Exposição de Motivos do Código Penal de 1940, quanto aos crimes contra os costumes, afirmava que o direito penal não poderia abdicar de sua função ética para "acomodar-se ao afrouxamento dos costumes". A doutrina entendia que o bem jurídico tutelado por este delito era a moralidade pública e os bons costumes ${ }^{294}$, ou nas palavras de Magalhães Noronha ${ }^{295}$, “a honra sexual contra os assaltos dos lenões internacionais”.

${ }^{293}$ SILVA, Marco Antonio Marques da. Trabalho escravo e dignidade humana. In: MARZAGÃO JÚNIOR, Laerte (coord.). Tráfico de pessoas, p. 202.

${ }^{294}$ Para Fragoso, op. cit., p. 530, o bem jurídico tutelado era a moral pública sexual.

${ }^{295}$ NORONHA, op. cit., p. 240. 
Alguns autores, no entanto, mesmo com as alterações ocorridas na legislação e pela modernização da sociedade, preservaram o entendimento de que o bem jurídico protegido é a moralidade pública sexual ${ }^{296}$. Para Paulo José da Costa Júnior ${ }^{297}$, tutelam-se os bons costumes, a dignidade sexual e a liberdade sexual. Celso Delmanto ${ }^{298}$ entende como objeto jurídico a moralidade pública sexual, mas no caso do art. 231 , $\S 2^{\circ}$, I a III, protege-se também a dignidade sexual, e no caso do art. 231, $\S 2^{\circ}$, IV, tutela-se também a liberdade sexual.

Para Cezar Bitencourt ${ }^{299}$ o bem jurídico tutelado também é a moralidade pública sexual. Para o autor, a dignidade sexual do ser humano, como parte integrante da personalidade do indivíduo, é tutelada genericamente para todos os crimes contra a dignidade sexual. Na sua visão, o intuito desse artigo é impedir que prostitutas estrangeiras ampliem o grande problema ético-social que é a prostituição. Ele chega a afirmar que, em uma visão bem-humorada, isso poderia parecer uma espécie de reserva de mercado, impedindo que a concorrência estrangeira ingresse no mercado nacional da prostituição.

Maria Elizabeth Queijo e João Daniel Rassi ${ }^{300}$, discorrendo sobre o delineamento dos possíveis bens jurídicos protegidos no delito de tráfico internacional de pessoas, afirmam que existem teorias conciliadoras que situam o tráfico como delito pluriofensivo que afeta diversos bens jurídicos, inclusive os direitos humanos das pessoas traficadas.

Na opinião de Daniel de Resende Salgado ${ }^{301}$ o bem jurídico tutelado pelo art. 231 do Código Penal é a dignidade humana dos trabalhadores sexuais, a liberdade da pessoa, o direito à sexualidade, que deve ser protegida de qualquer exploração.

Para Renato Silveira ${ }^{302}$, a tutela deve ser da liberdade de autodeterminação sexual, justificando-se o crime apenas quando verificadas a violência e a grave ameaça. No mesmo

\footnotetext{
296 Nesse sentido: Damásio de Jesus, Direito penal, v. 3, p. 199: “Objeto jurídico são os bons costumes, protegendo-se a honra sexual contra lenões internacionais".

${ }^{297}$ COSTA JÚNIOR, Paulo José da. Curso de direito penal, p. 711.

${ }^{298}$ DELMANTO, Celso et. al. Código Penal comentado, p. 720.

${ }^{299}$ BITENCOURT, Cezar. Tratado de direito penal, v. 4, p. 183.

300 QUEIJO, Maria Elizabeth; RASSI, João Daniel. Tráfico internacional de pessoas e o Tribunal Penal Internacional. In: MARZAGÃO JÚNIOR, Laerte (coord.). Tráfico de pessoas, p. 232-235.

${ }^{301}$ Daniel de Resende Salgado, O bem jurídico tutelado pela criminalização do tráfico internacional de seres humanos. Disponível em: <http://www.prsp.mpf.gov.br/prdc/area-de-atuacao/escravidao-e-trafico-de-sereshumanos>. Acesso em: 13 dez. 2011.

${ }^{302}$ SILVEIRA, Renato de Mello Jorge. Crimes sexuais, p. 346.
} 
passo, Guilherme $\mathrm{Nucci}^{303}$, com base princípio da intervenção mínima, aventa a possibilidade do consentimento do ofendido afastar a ilicitude da conduta. Pois, superada a lesão à liberdade sexual, restaria somente a moralidade e os bons costumes, que não merecem guarida penal.

Não obstante a moralidade pública sexual tenha sido vista por muito tempo como bem jurídico nuclear tutelado pelo crime de tráfico de mulheres, nos termos da legislação vigente hoje - Código Penal (crimes contra a dignidade sexual) e Protocolo de Palermo -, não há mais falar em moralidade sexual como bem jurídico preponderante para esse crime, e sim em liberdade sexual, como elemento da dignidade humana. Dependendo do caso concreto, outros bens jurídicos devem ser aventados.

\subsection{SUJEITO ATIVO}

O tráfico internacional de pessoas é crime comum quanto ao sujeito ativo, sem distinção de qualquer natureza. $\mathrm{O}$ autor do delito pode ser o homem ou a mulher, e não é necessária a habitualidade. Nas palavras de Hungria ${ }^{304}$, os traficantes aparecem como fornecedores do mercado sexual.

Porém, se o agente for ascendente, padrasto, madrasta, irmão, enteado, cônjuge, companheiro, tutor ou curador, preceptor ou empregador da vítima, ou se assumiu, por lei ou outra forma, obrigação de cuidado, proteção ou vigilância, a pena será aumentada da metade, nos termos do art. 231, $\S 2^{\circ}$, III, do Código Penal.

Trata-se de crime unissubjetivo, mas que admite coautoria ou participação, nos termos do art. 29 do Código Penal ${ }^{305}$. Além disso, esse delito pode ser cometido por pequenas quadrilhas ou bando, e também por grandes organizações criminosas, com divisão clara de tarefas entre seus integrantes, que é justamente o foco do Protocolo de Palermo.

\footnotetext{
${ }^{303}$ NUCCI, Guilherme. Crimes contra a dignidade sexual, p. 157-158.

${ }^{304}$ HUNGRIA, Nélson. Comentários ao Código Penal, p. 293.

305 Nesse sentido: TRF $1^{\mathrm{a}}$ Região, Apelação Criminal 2001.38.03.002448-8, rel. Des. Cândido Ribeiro, j. em 22-9-2009; TRF 1 ${ }^{\mathrm{a}}$ Região, Apelação Criminal 2006.30.00.001602-7, rel. Des. Tourinho Neto, j. em 28-72009.
} 


\subsection{SUJEITO PASSIVO}

Pode ser vítima de tráfico de pessoas qualquer ser humano, homem ou mulher. Em sua redação original, o Código Penal de 1940 trazia como sujeito passivo apenas a mulher. O próprio nomen juris do delito era tráfico de mulheres. Com o advento da Lei n. 11.106, de 2005, o delito passou a tratar do tráfico de pessoas. Embora pareça evidente, ainda hoje é necessário afirmar que qualquer tipo de pessoa pode ser vítima do crime, inclusive prostitutas $^{306}$ e 307 .

A lei não exige a pluralidade de vítimas, embora esta seja a prática mais comum. A rubrica do artigo fala em tráfico de pessoa, no singular. Elas podem ser aliciadas ou transportadas juntas ou separadamente, a depender do modus operandi da organização.

Para os autores que consideram a moralidade pública o bem jurídico tutelado pelo delito, o sujeito passivo é também a coletividade.

Nos termos do $\S 2^{\circ}$ do art. 231 do Código Penal, a condição particular da vítima justifica o aumento da pena. Quando for menor de 18 anos (inciso I), ou quando por enfermidade ou deficiência mental não tiver o necessário discernimento para a prática do ato (inciso II), a pena deverá aumentar da metade.

As mulheres continuam a ser as principais vítimas. Tanto é assim que o Protocolo de Palermo protege especialmente mulheres e crianças. Isso não impede, contudo, que homens também sejam traficados, na maioria meninos, travestis ou transexuais.

As vítimas não são escolhidas aleatoriamente. Dá-se preferência às vulneráveis ou mais facilmente manipuláveis. Algumas características são encontradas na maioria delas, como baixa escolaridade, família desestruturada, gravidez na adolescência, carência afetiva, ingenuidade, o sonho de uma vida melhor, a busca pelo príncipe encantado ${ }^{308}$.

\footnotetext{
${ }^{306}$ Nesse sentido: STF, Extradição 725, rel. Min. Maurício Corrêa, j. em 2-9-1998.

${ }^{307}$ Para Cezar Bitencourt, op. cit., p. 184, o sujeito passivo poderá ser tanto o homem quanto a mulher, "independentemente de sua honestidade sexual".

${ }^{308}$ Sobre o assunto, assistir o documentário: Cinderelas, lobos e um príncipe encantado. Direção e Produção Executiva: Joel Zito, Brasil, 2008.
} 
Bento de Faria ${ }^{309}$ já afirmava em meados do século passado que o êxito do recrutamento é quase sempre determinado pela "miséria das infelizes".

O consentimento da vítima é irrelevante para a configuração do delito ${ }^{310}$. Mesmo que não haja qualquer tipo de violência, ameaça ou engodo, havendo a saída ou entrada no território nacional para o exercício da prostituição estará configurado o delito.

Porém, existem casos onde a violência é a regra. A vítima de tráfico de pessoas que sofre exploração sexual é manipulada, torturada, coagida, chantageada, violentada, humilhada. Além de todo o sofrimento físico, há o sofrimento psíquico. Em regra, ao chegar ao destino, a vítima é privada de seu passaporte, passando a ficar sob a guarda de outrem, às vezes confinada em locais de onde não pode fugir, sujeita a maus-tratos, obrigada a consumir drogas. Nas situações em que não falam o idioma local, e por desconhecerem as leis e a cultura do país, ficam mais vulneráveis e são constantemente ameaçadas pelos seus exploradores com a possibilidade de deportação ou prisão. A culpa e o medo mantêm a vítima em silêncio mesmo quando consegue fugir de seu cativeiro. Quanto mais quebradas psicologicamente, mais obedientes ${ }^{311}$.

No livro Sex trafficking, Siddharth Kara ${ }^{312}$ afirma que nos bordéis e abrigos que visitou pelo mundo encontrou mulheres e crianças que sofreram atos indescritíveis de barbárie, e se encontravam debilitadas por ferimentos, má nutrição, traumas psicológicos, transtorno de estresse pós-traumático e doenças sexualmente transmissíveis, inclusive $\operatorname{AIDS}^{313}$. O autor relata os medos que mantêm essas pessoas em silêncio, mesmo quando já estão longe das mãos dos traficantes ${ }^{314}$. Elas não desejam reviver a agonia e o sofrimento a que foram submetidas. Temem a vergonha a que estariam sujeitas se seus conterrâneos

\footnotetext{
${ }^{309}$ FARIA, Bento. Código Penal brasileiro comentado, p. 108.

${ }^{310}$ A esse respeito, vide Capítulo 7.

311 Bento de Faria, op. cit, p. 108, sintetiza a situação das escravas sexuais: "Sem um queixume, sem esperanças, fracas pelo sexo, pela desgraça e pelo isolamento, em um país estranho, cujas leis desconhecem, extinguem-se-lhes o sentimento de pudor e de revolta, habituam-se ao meio, e, fato notável, são incapazes de denunciarem à Justiça a mão que as esbofeteia quando a atração e o gozo dos seus corpos não conseguiram proporcionar a féria tabelada pela infâmia de quem as explora".

312 Segundo o autor, nada que ele escreva poderá relatar fielmente o sentimento transmitido pelo olhar dessas vítimas: "Nothing I write can possibly convey the sensation of peering into the moribund eyes of a broken child who has been forced to have sex with hundreds of men before the age of sixteen". In: Sex trafficking: inside the business of modern slavery, $\mathrm{p}$. X.

${ }^{313}$ KARA, op. cit., p. XIII e XIV.

${ }^{314}$ Idem, p. XIII.
} 
soubessem o tipo de violência que sofreram e também que suas famílias sofram algum tipo de retaliação por parte dos traficantes, que sempre as ameaçaram nesse sentido.

Theresa Flores, vítima de exploração sexual, afirma: "Eu sentia que não tinha outra escolha senão me submeter; fazer o que me mandavam ou eu seria severamente punida. Os meus entes queridos poderiam ser feridos ou assassinados. E isso não era uma opção para $\operatorname{mim}, 315$.

\subsection{TIPO OBJETIVO}

O tipo previsto no art. 231, caput, do Código Penal pune aquele que promove ou facilita a entrada de alguém (homem ou mulher) no território nacional, que venha a exercer a prostituição ou outra forma de exploração sexual. A segunda parte do caput visa coibir a facilitação ou promoção da saída de alguém para a mesma finalidade em território estrangeiro.

Promover significa organizar, dar causa, dar impulso, oferecer recursos para determinada atividade. Facilitar consiste em tornar algo mais fácil ou acessível, favorecer, proporcionar meios para que algo se realize.

A saída da vítima para o exterior exige uma série de providências, como passaporte, visto, passagem, roupas e dinheiro para a viagem. Promover e facilitar se enquadram nesse contexto. Segundo Rogério Greco ${ }^{316}$, promover é uma conduta ampla, podendo até mesmo abranger a facilitação.

Aquele que facilita ou promove a ida de alguém ao exterior para exercer a prostituição, que é uma atividade lícita no Brasil e em diversos outros países, é punido com reclusão de 3 a 8 anos. Da forma como está redigido o dispositivo legal, enquadra-se na conduta aquele que empresta o dinheiro da passagem a alguém sabendo que a finalidade da

315 "I felt that I had no choice but to submit, to do as I was told or be severely punished. My loved ones would be harmed or killed. And that was not an option to me" (tradução nossa). In: FLORES, Theresa L. The slave across the street, p. 153.

${ }^{316}$ GRECO, Rogério. Curso de direito penal, v. III, p. 617. 
viagem é exercer a prostituição no exterior. Se a prostituição no país de origem e destino não for crime, por que falar em crime daquele que facilita ou promove a viagem?

Deve-se observar nesta questão a tipicidade material, e não simplesmente a formal. Assim, além da conduta se adequar ao tipo, precisa ser materialmente lesiva ao bem jurídico tutelado.

Entende-se que uma interpretação possível e mais justa seria punir o crime de tráfico para fim de prostituição apenas quando esta se apresentar efetivamente como forma de exploração, ou seja, quando o autor do delito auferir vantagem de forma ilícita da prostituição de outrem, mediante violência, ameaça, ardil ou abuso de situação de vulnerabilidade.

Se a entrada no país se der de forma irregular, violando normas de imigração, com o uso de documentos falsos ou outras práticas, o traficante responderá em concurso de crimes.

$\mathrm{O} \S 1^{\circ}$ do art. 231 equipara as condutas agenciar, aliciar, comprar, transportar, transferir ou alojar a vítima às condutas previstas no caput, aplicando-lhes a mesma pena.

As condutas previstas no $\S 1^{\circ}$, que prescinde do uso da violência, fraude ou ameaça, apresentam diferentes esferas de gravidade, o que gera uma grande desproporcionalidade no tipo. Aquele que compra um ser humano sofre a mesma pena daquele que o transporta, por exemplo $^{317}$.

Agenciar significa intermediar um negócio; providenciar, obter ou buscar algo para alguém. É a conduta daquele que coloca a vítima em contato com o explorador. O verbo aliciar denota a conduta daquele que atrai, convence ou estimula a vítima a viajar. $\mathrm{O} \S 1^{\circ}$ não exige, mas em regra esse convencimento se dá por meio de ardil, de falsas promessas de um trabalho bom e rentável no exterior. A promessa de uma vida melhor.

\footnotetext{
317 Segundo Guilherme Nucci, op. cit., p. 159: "Soa-nos desmedida a comparação em iguais termos entre aliciar e comprar, por exemplo. Quem seduz alguém à prática de algo realiza ação inferior, em gravidade, do que o comprador da pessoa traficada. Não haveria de existir a equiparação, visto que o aliciador poderia, até mesmo, ser considerado um partícipe de menor importância”.
} 
Comprar $^{318}$ é adquirir algo mediante o pagamento de determinado preço. O legislador se omitiu quando àquele que vende ${ }^{319}$ a pessoa traficada.

Transportar ou transferir são condutas que indicam movimentação. Transportar significa levar ou conduzir alguém de um lugar para outro, por qualquer meio de transporte. Transferir é mudar a pessoa de um lugar para o outro. Segundo Renato Marcão e Plínio Gentil ${ }^{320}$ há uma sutil diferença entre os dois verbos. O primeiro descreve a conduta daquele que leva alguém para o local em que se pratica a exploração sexual. $\mathrm{O}$ segundo trata da transferência de um lugar onde se pratica a exploração para outro de igual destinação.

Alojar é dar abrigo ou hospedar alguém. O alojamento pode se dar em locais destinados à prostituição ou não. Dependendo do caso pode até configurar cárcere privado e sequestro (art. 148 do Código Penal), ou redução à condição análoga a de escravo (art. 149 do Código Penal), quando a vítima é tolhida em seu direito de ir e vir.

O tipo é misto alternativo ${ }^{321}$, ou seja, a prática de mais de uma conduta, no mesmo cenário, envolvendo as mesmas vítimas, constitui delito único. O objeto material do crime é o ser humano.

$\mathrm{O} \S 2^{\circ}$ do art. 231 enumera as causas de aumento de pena, que deve elevar-se da metade. Os incisos I e II dispõem sobre a condição da vítima. Há aumento da pena quando esta é menor de 18 anos, ou, por enfermidade ou deficiência mental, não possui o discernimento necessário para a prática do ato, conforme já mencionado.

O inciso III dispõe sobre a condição especial do sujeito ativo. Aumenta-se a pena quando o agente é ascendente, padrasto, madrasta, irmão, enteado, cônjuge, companheiro, tutor ou curador, preceptor ou empregador da vítima, ou se assumiu, por lei ou outra forma, obrigação de cuidado, proteção ou vigilância.

\footnotetext{
${ }^{318}$ Segundo João Daniel Rassi e Alessandra Greco: "Pessoa não é coisa, portanto não se compra nem se vende. Trata-se de linguagem vulgar que seria inadmissível na legislação". In: Crimes contra a dignidade sexual, p. 191.

${ }^{319}$ A conduta de vender a pessoa traficada consta apenas no art. 231-A, $\S 1^{\circ}$, do Código Penal, que dispõe sobre o tráfico interno de pessoas.

${ }^{320}$ MARCÃO, Renato; GENTIL, Plínio. Crimes contra a dignidade sexual, p. 360.

${ }^{321}$ Nesse sentido: Guilherme Nucci, op. cit., p. 158.
} 
A última causa de aumento de pena, prevista no inciso IV do $\S 2^{\circ}$, dispõe sobre o cometimento do delito com o emprego de violência, grave ameaça ou fraude. Entende-se ${ }^{322}$ que o tráfico só se justificaria quando presentes esses elementos, e não como ocorre no caput e no $\S 1^{\circ}$ do art. 231, onde o consentimento da vítima é totalmente irrelevante.

Para Tadeu Dix Silva ${ }^{323}$ o tipo do art. 231, caput, é inócuo para a prevenção do tráfico internacional de pessoas, pois não prevê a violência, a grave ameaça, a fraude, a exploração de situação de abandono ou de necessidade econômica. Afirma esse autor que a punição é simbólica, pois não tutela a liberdade sexual de ninguém, pelo contrário. "A pessoa que - livre de coação ou qualquer forma de exploração - vem a exercer a prostituição no Brasil estará em pleno exercício de sua liberdade sexual, porque entre nós o ato de se prostituir não consiste em nenhum delito". O mesmo ocorre com quem se dirige ao exterior com o intuito de lá se prostituir. Para o autor "não se vislumbra delito algum" em face do consentimento livre do homem ou da mulher.

Para o autor ${ }^{324}$ fica claro no Protocolo de Palermo que a prostituição voluntária não é suficiente para caracterizar o tráfico de pessoas, sendo plenamente válido o consentimento que não for obtido pelos meios previstos no art. $3^{\circ}, a$, do Protocolo.

O Código Penal de 1940 adotou a teoria da ubiquidade (art. 6º ). Assim, o tráfico como um todo se entende praticado no Brasil desde que no território nacional se realize qualquer dos elementos constitutivos, seja quanto à atividade, seja quanto ao resultado. Nem sempre o Brasil é o país de origem ou destino, podendo servir apenas como passagem. Ainda nesses casos o delito se perfaz, pois pode enquadrar-se na conduta daquele que sai do País com o intuito de exercer a prostituição.

$\mathrm{O}$ art. 231 ignora a conduta daquele que usa os serviços da pessoa traficada, mesmo quando consciente dessa condição. Não se pode admitir a impunidade do cliente que utiliza serviços sexuais de vítima de tráfico de pessoas em condição de escravidão ou análoga, mesmo que seja com dolo eventual. A esse respeito a legislação portuguesa andou bem ao

\footnotetext{
${ }^{322}$ Nesse sentido: Guilherme Nucci, op. cit,, p. 160, e Renato Silveira, op. cit., p. 346. Em sentido contrário: André Estefam, op. cit., p. 138.

${ }^{323}$ SILVA, Tadeu Dix. Crimes sexuais: reflexões sobre a nova Lei n. 11.106/2005, p. 315-316.

${ }^{324}$ Idem, p. 317.
} 
criminalizar a conduta daquele que utiliza os serviços da vítima (art. 160, 5, do Código Penal português).

\subsection{ELEMENTO SUBJETIVO}

É o dolo, ou seja, a vontade livre e consciente de praticar o tráfico internacional de pessoa para fim de exploração sexual. Existem duas correntes: a que aceita o dolo genérico e a que exige o dolo específico.

Para alguns doutrinadores ${ }^{325}$, basta o dolo genérico de praticar uma das ações típicas com o conhecimento de que a pessoa é traficada para exercer a prostituição ou ser explorada sexualmente. $\mathrm{O}$ desconhecimento a respeito da atividade a ser exercida é erro de tipo e exclui o dolo.

Para Guilherme Nucci ${ }^{326}$ e Cezar Bitencourt ${ }^{327}$, exigi-se o especial fim de agir ou dolo específico ${ }^{328}$, ou seja, o sujeito atuar com o intuito de ver a vítima submetida à prostituição ou a outra forma de exploração sexual. Para qualquer conduta descrita no caput ou $\S 1^{\circ}$ do art. 231 do Código há essa exigência.

Entende-se correta esta última posição. Conforme lição de Cezar Bitencourt ${ }^{329}$, o próprio nomen juris do delito põe cabo a essa discussão: tráfico internacional de pessoa para fim de exploração sexual. Segundo o autor, a finalidade de exploração sexual configura o elemento subjetivo especial do tipo, que não precisa concretizar-se, sendo suficiente que tenha sido motivador da conduta do sujeito ativo.

\footnotetext{
325 Nesse sentido: Júlio Fabbrini Mirabete e Renato N. Fabbrini, Código penal interpretado, p. 1.440; Damásio de Jesus, op. cit., v. 3, p. 201; André Estefam, op. cit., p. 140; João Rassi e Alessandra Greco, op. cit., p. 190; Tadeu Dix Silva, op. cit., p. 312; Celso Delmanto, op. cit., p. 721; e Paulo José da Costa Jr, op. cit., p. 713.

${ }^{326}$ NUCCI, op. cit., p. 160-161.

${ }^{327}$ BITENCOURT, op. cit., p. 185.

${ }^{328}$ No mesmo sentido Renato Marcão e Plínio Gentil, op. cit., p. 363; e Maximiliano Führer, Novos crimes sexuais, p. 209.

${ }^{329}$ BITENCOURT, op. cit., p. 185-186.
} 
Se o delito for praticado com o intuito de obter vantagem econômica, aplica-se também a pena de multa, nos termos no art. 231, $\S 3^{\circ}$, do Código Penal. Não é necessário que a vantagem seja efetivamente obtida.

Não é admitida a modalidade culposa.

\subsection{CONSUMAÇÃO E TENTATIVA}

No tocante à consumação, existem também duas correntes. A primeira ${ }^{330}$ delas entende que o delito é instantâneo e se consuma com a entrada da vítima no País, ou com a sua saída rumo ao exterior, independentemente do efetivo exercício da prostituição ${ }^{331}$. Basta que a entrada ou saída do território seja feita com esse propósito.

O exercício da prostituição no Brasil ou no exterior constitui o exaurimento do crime, quando este alcança suas últimas consequências, e pode influenciar no quantum da pena.

Em sentido contrário, a corrente defendida por Guilherme Nucci ${ }^{332}$ e Rogério Greco $^{333}$ entende que existe necessidade do efetivo exercício da prostituição para que o crime se consume.

De um ponto de vista utilitário, a posição que defende o efetivo exercício da prostituição, mormente quando esta ocorre no exterior, tornaria a punição muito difícil. Todo o trâmite processual e a produção das provas seriam muito difíceis e demorados, pois estariam à mercê de evento futuro e incerto.

\footnotetext{
${ }^{330}$ Nesse sentido: Nélson Hungria, op. cit., p. 298; Cezar Bitencourt, op. cit., p. 186; André Estefam, op. cit., p. 142; Renato Marcão e Plínio Gentil, op. cit., p. 364; Júlio Fabbrini Mirabete e Renato N. Fabbrini, Código Penal interpretado, p. 1.440; Damásio de Jesus, op. cit., v. 3, p. 201; João Rassi e Alessandra Greco, op. cit., p. 190; Tadeu Dix Silva, op. cit., p. 312; Maximiliano Führer, op. cit., p. 209; Celso Delmanto, op. cit., p. 721; e Paulo José da Costa Jr, op. cit., p. 713.

${ }^{331}$ Nesse sentido: TRF $3^{\text {a }}$ Região, Apelação Criminal 2005.03.99.009508-0, rel. Des. André Nekatschalow, j. em 20-3-2006; TRF $1^{a}$ Região, Apelação Criminal 2006.30.00.001602-7, rel. Des. Tourinho Neto, j. em 287-2009.

${ }^{332}$ NUCCI, op. cit., p. 159.

${ }^{333}$ GRECO, Rogério, op. cit., p. 618.
} 
A finalidade do tráfico é a exploração, que pode ocorrer em bordéis, dance clubs, casas de massagens, apartamentos, hotéis e nas ruas. Locais com muitas ou poucas vítimas. Não há regras. Contudo, a exploração em si não é tutelada pelo art. 231.

No tocante à tentativa, para a tese majoritária ${ }^{334}$ esta é perfeitamente admissível $^{335}$. Como se trata de crime plurissubsistente, cuja conduta apresenta fracionamento, o deslocamento completo do sujeito de um país a outro pode não se consumar por circunstâncias alheias a sua vontade.

Em sentido contrário, Guilherme Nucci ${ }^{336}$ afirma que a tentativa é inadmissível, por se tratar de crime condicionado.

Nas modalidades equiparadas do $\S 1^{\circ}$ do art. 231 , o delito se consuma com o agenciamento, aliciamento ou compra da pessoa traficada, ou com seu transporte, transferência ou alojamento, sendo as três últimas modalidades de crime permanente, admitindo o flagrante a qualquer tempo ${ }^{337}$. Para todas as modalidades há necessidade da ciência da condição de pessoa traficada ${ }^{338}$.

\subsection{FINALIDADE DE LUCRO, “LAVAGEM" DE DINHEIRO E CRIME ORGANIZADO}

$\mathrm{O} \S 3^{\circ}$ do art. 231 do Código Penal menciona que se o crime for cometido com o fim de obter vantagem econômica, aplica-se também multa. Para Renato Marcão e Plínio Gentil $^{339}$ a vantagem econômica inclui qualquer benefício que possa representar expressão econômica, seja dinheiro, bens, favores. Além disso, não é necessário que a vantagem se destine ao agente, tampouco seja efetivamente obtida. Basta que haja o dolo mercenário.

\footnotetext{
${ }^{334}$ Nesse sentido: Cezar Bitencourt, op. cit., p. 186; Renato Marcão e Plínio Gentil, op. cit., p. 367; Damásio de Jesus, op. cit., v. 3, p. 201; André Estefam, op. cit., p. 143; João Rassi e Alessandra Greco, op. cit., p. 191; Rogério Greco, op. cit., p. 619; Celso Delmanto, op. cit., p. 721; e Paulo José da Costa Jr, op. cit., p. 713.

${ }^{335}$ Nesse sentido: TRF $3^{a}$ Região, Apelação Criminal 2004.61.06.004897-4, rel. Des. Ramza Tartuce, j. em 29-10-2007.

${ }^{336}$ NUCCI, op. cit., p. 161.

${ }^{337}$ CUNHA, Rogério Sanches et. al. Comentários à reforma criminal de 2009 e à Convenção de Viena sobre o Direito dos Tratados, p. 73.

${ }^{338}$ MARCÃO e GENTIL, op. cit., p. 365.

${ }^{339}$ Idem, p. 362-363.
} 
O fenômeno do tráfico, de forma geral, só pode ser concebido quando presente a vantagem econômica. Esta é, na verdade, a finalidade do delito. Trata-se de mais um negócio. Hoje essa modalidade de tráfico aparece como uma das atividades mais lucrativas das organizações criminosas, ao lado do tráfico de armas e de drogas.

Como negócio ilícito, surge a necessidade para as organizações criminosas de realizar as operações de "lavagem" de dinheiro, ou seja, transformar recursos oriundos de atividades ilícitas em ativos com origem aparentemente legal. Contudo, o delito de tráfico de pessoas não consta na lista de crimes antecedentes do art. $1^{\circ}$ da Lei n. 9.613, de 1998 (Lei de "Lavagem" de Dinheiro), como ocorre com o tráfico de drogas (inciso I) e o tráfico de armas (inciso III).

O inciso VII do art. $1^{\circ}$ da referida norma abre uma possibilidade para a sua aplicação ao crime de tráfico de pessoas, pois inclui os delitos praticados por organização criminosa ao rol de crimes antecedentes. Para Damásio de Jesus ${ }^{340}$ a aplicação desse dispositivo é difícil e não resolve o problema, pois a legislação brasileira ainda não definiu “organização criminosa”. Além disso, o tráfico pode ser cometido individualmente, em concurso de agentes ou por quadrilha ou bando, fugindo assim ao âmbito de aplicação do mencionado inciso. O ideal seria a inclusão do crime de tráfico de pessoas no rol de crimes antecedentes $^{341}$. A Convenção de Palermo dispõe sobre a criminalização da "lavagem" do produto do que crime, que ficará a critério de cada país ${ }^{342}$.

O tráfico de pessoas para fim de exploração sexual, desde quando tomou relevo no final do século XIX, esteve associado ao crime organizado. Não as organizações criminosas no formato que conhecemos hoje, mas um esboço delas. Bento de Faria ${ }^{343}$ menciona uma perigosa associação internacional de traficantes - Zwig Migdal ${ }^{344}$, fundada na Polônia, com várias ramificações e dispondo de grande capital. Na América Latina ela

\footnotetext{
${ }^{340}$ JESUS, Damásio Evangelista de. Lavagem de dinheiro proveniente de tráfico internacional de mulheres e crianças não constitui crime. Revista da AJUFE, p.63-68.

${ }^{341}$ BARROS, Marco Antonio de. Tráfico de pessoas para fim de exploração sexual e a adoção internacional fraudulenta. Disponível em: <http://www.cnj.jus.br/dpj/cji/handle/26501/1883>. Acesso em: 26 dez. 2011.

${ }^{342}$ Para Elena Florência Onassis: "Todo Estado que pretenda combatir la trata de personas, debe incluir regímenes de decomiso que prevean la identificación, la localización, el embargo preventivo y la incautación de los fondos adquiridos ilícitamente". In: Trata de personas: la esclavitud del siglo XXI, p. 68.

${ }^{343}$ FARIA, op. cit., p. 109-110.

${ }^{344}$ A organização é também mencionada In: NIREMPERGER, Zunilda; RONDAN; Francisco. Mercaderes de vida: una visión histórica, sociológica y jurídica del delito de trata de personas, p. 24, 26-29.
} 
teria se instalado em Buenos Aires, até ser fechada pela polícia em 1930. Essa organização era reconhecida pela crueldade no trato com suas escravas e também com seus membros. Seus agentes iam para as aldeias polacas, húngaras, ucranianas, lituanas, onde a miséria chegava a ser lúgubre, e de lá traziam as vítimas, com a promessa de trabalharem em ateliês, companhias teatrais e cabarés. Porém, para Nélson Hungria ${ }^{345}$ a existência da Zwig Migdal nunca foi provada.

Hoje a delinquência organizada transnacional tem uma ligação estreita com a globalização, podendo ser considerada sua infeliz consequência. O crime organizado usufrui da abertura de fronteiras e mercados, do avanço tecnológico e da jurisdição limitada dos países e das falhas dos sistemas jurídicos internos e incompatibilidades entre Estados.

A Convenção das Nações Unidas contra o Crime Organizado, também conhecida como Convenção de Palermo ${ }^{346}$, tem como objetivo promover a cooperação para prevenir e combater mais eficazmente a criminalidade organizada transnacional. O Protocolo de Palermo ${ }^{347}$ completa esta Convenção no tocante ao tráfico de pessoas. Assim, conforme o art. $4^{\circ}$ do mencionado Protocolo, o seu âmbito de aplicação inclui as infrações de natureza transnacional e que envolverem grupo criminoso organizado.

A Convenção de Palermo, em seu art. $2^{\circ}$, busca definir grupo criminoso organizado nos seguintes termos: "grupo estruturado de três ou mais pessoas, existente há algum tempo e atuando concertadamente com o propósito de cometer uma ou mais infrações graves ou enunciadas na presente Convenção, com a intenção de obter, direta ou indiretamente, um benefício econômico ou outro benefício material;". Contudo, essa definição não obtém acolhimento pacífico na doutrina nacional.

Segundo leciona Vicente Greco Filho ${ }^{348}$, não há no Brasil definição legal de organização criminosa, já que a Lei n. 9.034, de 1995, estabelece apenas medidas de ordem processual, investigativa e administrativa no combate a essas organizações, sem dar-lhes

\footnotetext{
${ }^{345}$ HUNGRIA, op. cit., p. 293-295.

${ }^{346}$ Decreto n. 5.015, de 2004.

${ }^{347}$ Decreto n. 5.017, de 2004.

${ }^{348}$ GRECO FILHO, Vicente. A entrega vigiada e tráfico de pessoas. In: MARZAGÃO JÚNIOR, Laerte (coord.). Tráfico de pessoas, p. 289-293.
} 
uma conceituação. Continua afirmando que a definição da Convenção de Palermo se mostra imprestável para o direito brasileiro, eis que não estabelece a distinção entre quadrilha ou bando e grupo criminoso organizado. Além disso, um conceito legal engessaria a aplicação da norma, já que as organizações são muito diferentes entre si. Para o autor, devem-se extrair da doutrina as características básicas de uma organização criminosa, pois "o conceito deve manter-se fluido, como fluido é o próprio modo de ser de uma societas sceleris",349.

Em delitos dessa espécie, em que inúmeros agentes contribuem na produção do resultado, propicia-se o anonimato, dificultando-se a atribuição de responsabilidades, o estabelecimento do nexo causal e a delimitação da culpa ${ }^{350}$. Esse é um dos motivos do pequeno número de processos relativos ao tráfico internacional de pessoas no Brasil.

Desta forma, é imperioso e urgente que tanto os países isoladamente, como toda a comunidade internacional aprendam a lidar com essas novas formas de criminalidade. Segundo Alessandra Greco e João Daniel Rassi ${ }^{351}$, as organizações criminosas atuais não podem mais ser associadas aos tradicionais conceitos de crime organizado, que se referiam a um grupo familiar ou étnico que se dedicava a uma atividade ilícita específica. Hoje elas são multiétnicas e muitas vezes compostas por grupos provenientes de diferentes países, pulverizando-se pelo mundo todo.

\footnotetext{
${ }^{349}$ Para Vicente Greco Filho, op. cit., p. 292-293, uma organização criminosa deve ter os seguintes elementos: 1) Estrutura organizacional, com células relativamente estanques, de modo que uma não tem a identificação dos componentes da outra. 2) Especialização de tarefas, de modo que cada um exerce uma atividade predominante. 3) A existência de vários níveis de hierarquia, em que os subordinados nem sempre, ou quase nunca, conhecem a identidade da chefia de dois ou mais escalões superiores, e ainda que conheçam, não têm contato direto com ela para não poder produzir provas. 4) A possível, e quase necessária, existência de infiltração de membros de organização em atividades públicas, no Poder Executivo, Legislativo, Judiciário e Ministério Público e a corrupção de agentes públicos. 5) A tendência de durabilidade. 6) A conexão com outras organizações, no mesmo ramo ou em ramo diferente, quando não a atividade em vários ramos. 7) A coação, mediante violência, chantagem ou aproveitamento da condição de pessoas não participantes, mas que passam a ser auxiliares ou coniventes e que vivem sob a imposição de grave dano em caso de delação. 8) Mais de três pessoas.

${ }^{350}$ PRADO, Stela; CAPEZ, Fernando. Considerações sobre o tráfico de pessoas e organizações criminosas. In: CARNEIRO, José Reinaldo; MESSA, Ana Flávia (coord.). Crime organizado, p. 541.

${ }^{351}$ GRECO, Alessandra Orcesi Pedro; RASSI, João Daniel. Crime organizado transnacional e o tráfico internacional de pessoas no direito brasileiro. In: CARNEIRO, José Reinaldo; MESSA, Ana Flávia (coord.). Crime organizado, p. 618.
} 


\subsection{AÇÃO PENAL E COMPETÊNCIA}

A ação penal para o crime de tráfico internacional de pessoas para fim de exploração sexual é pública incondicionada. A regra do art. 225 do Código Penal - ação penal pública condicionada à representação - não se aplica a esse delito. A competência para propor a ação é do Ministério Público Federal.

$\mathrm{O}$ art. 109 da Constituição brasileira determina a competência ratione materiae da Justiça Federal. Nos termos do seu inciso V, aos juízes federais compete processar e julgar os crimes previstos em tratado ou convenção internacional, quando, iniciada a execução no País, o resultado tenha ou devesse ter ocorrido no estrangeiro, ou reciprocamente.

Assim, como o tráfico internacional de pessoas é um delito transnacional, previsto no Protocolo de Palermo ${ }^{352}$, é fixada a competência da Justiça Federal ${ }^{353}$.

Nos termos do art. 234-B do Código Penal os processos que apuram os crimes contra a dignidade sexual correrão em segredo de justiça.

\subsubsection{Competência do Tribunal Penal Internacional e cooperação jurídica internacional}

A noção de direitos fundamentais inerentes ao ser humano é antiga, tendo como marco a Declaração dos Direitos do Homem e do Cidadão, de 1789. Porém, a sua proteção internacional ainda é recente. O denominado direito internacional dos direitos humanos" 354 surgiu no pós-Guerra, tendo em vista as atrozes violações de direitos humanos cometidas pelo nazismo.

A Organização das Nações Unidas - ONU ${ }^{355}$, foi fundada em 1945 por 51 países que se comprometeram a manter a paz e a segurança internacionais, a desenvolver relações

\footnotetext{
${ }^{352}$ Promulgado pelo Decreto n. 5.017/2004.

${ }^{353}$ Nesse sentido: STJ, Conflito de Competência 47.634, rel. Min. Paulo Medina, j. em 11-5-2005; e STJ, Habeas Corpus 208.421, rel. Min. Jorge Mussi, j. em 18-10-2011.

${ }^{354}$ PIOVESAN, Flávia. Temas de direitos humanos, p. 37 e 38.

${ }^{355}$ Disponível em: <http://www.un.org/es/aboutun/>. Acesso em: 17 fev. 2011.
} 
amistosas entre as nações e a promover o progresso social, melhores níveis de vida e os direitos humanos.

Com o advento da Declaração Universal de 1948 e da visão contemporânea de direitos humanos introduzida por ela, o direito internacional dos direitos humanos começa a se desenvolver por meio da adoção de inúmeros tratados internacionais voltados à proteção de direitos fundamentais ${ }^{356}$, motivando a cooperação entre as nações. No Brasil apenas com a promulgação da Constituição Federal de 1988 tivemos a institucionalização dos direitos humanos.

Toda nação tem o dever de respeitar os direitos humanos de seus cidadãos e dos estrangeiros presentes em seu território, e todas as nações e a comunidade internacional têm o direito e o dever de se manifestar se um Estado não cumprir suas obrigações nessa seara. Temos, assim, uma relativização da noção tradicional de soberania ${ }^{357}$, que permite formas de monitoramento e responsabilização internacional.

A internacionalização da jurisdição penal ${ }^{358}$ constitui um dos reflexos desse movimento, que pode ser visto não somente do ponto de vista da necessidade de se combater a impunidade, mas especialmente pela necessidade da efetivação dos direitos humanos. No sistema internacional é possível a responsabilização por meio dos Tribunais ad hoc e Tribunais Mistos ou Internacionalizados, de iniciativa do Conselho de Segurança da ONU, e também por meio do Tribunal Penal Internacional ${ }^{359}$.

O crime internacional será objeto de tutela pelos tribunais internacionais, como o Tribunal Penal Internacional.

Deve-se observar neste ponto que crime transnacional e crime internacional não se confundem. O primeiro cruza fronteiras e viola o bem jurídico de um ou mais Estados, e em regra é julgado por um só deles, de acordo com regras internas. Porém, para um crime ser considerado internacional, deve respeitar alguns requisitos. Embora não exista um

\footnotetext{
${ }^{356}$ PIOVESAN, op. cit., p. 44.

${ }^{357}$ Idem, p. 39

358 BECHARA, Fábio Ramazzini. Tráfico de seres humanos: competência jurisdicional penal para o julgamento das violações aos direitos humanos. In: MARZAGÃO JÚNIOR, Laerte (coord.). Tráfico de pessoas, p. 98.

${ }^{359}$ Idem, p. 99.
} 
conceito pacífico para essa categoria, conforme lição de Fernanda Jankov ${ }^{360}$, os requisitos são os seguintes: a) violar normas costumeiras internacionais; b) violar norma cujo objetivo é proteger valores considerados importantes para toda a comunidade internacional $^{361}$, consequentemente obrigatórias a todos os Estados e indivíduos (ex. Carta das Nações Unidas; Convenção Europeia dos Direitos Humanos; Convenção Americana sobre Direitos Humanos); e, c) deve existir interesse universal na repressão do crime. Segundo a autora esses requisitos devem ser considerados cumulativamente.

O Estatuto de Roma é uma convenção multilateral assinada em 17-7-1998, que deu origem ao TPI. O Tribunal é permanente e independente, complementar às jurisdições nacionais, e deverá julgar as pessoas responsáveis pelos crimes de maior gravidade com alcance internacional. Os três core crimes presentes no Estatuto são: crimes de guerra, crimes contra a humanidade e genocídio.

Segundo a diplomata Adriana Tescari ${ }^{362}$, o Estatuto de Roma é ainda de maior relevância por ter sido o primeiro tratado internacional a reconhecer atos de agressão sexual e de gênero como crimes graves tutelados pelo direito internacional ${ }^{363}$. Esse fato deve-se à jurisprudência resultante dos Tribunais ad hoc para a ex-Iugoslávia e para Ruanda, e especialmente à pressão de associações de mulheres, ativistas e ONGs durante a elaboração do Estatuto ${ }^{364}$.

Ao contrário dos Tribunais ad hoc, onde foi adotado o princípio da primazia, o Estatuto de Roma adotou do princípio da complementariedade, o que demonstra a preocupação dos países signatários em preservar a soberania nacional e o monopólio estatal do direito criminal, preferindo a competência da justiça nacional à internacional,

\footnotetext{
${ }^{360}$ JANKOV, Fernanda Florentino Fernandez. Direito internacional penal: mecanismo de implementação do Tribunal Penal Internacional, p. 57-59.

361 Há que se destacar que esse entendimento está relacionado à teoria do universalismo, adotada pela Declaração Universal dos Direitos do Homem. Tal teoria defende a garantia dos direitos mínimos a qualquer ser humano, independentemente de soberania do Estado, cultura, religião etc. Contudo, esse entendimento pode ser rebatido pela teoria do relativismo, que entende que as definições consideradas "internacionais" tiveram como base predominante a cultura ocidental. Logo, condutas consideradas crimes pelos países do ocidente podem ser consideradas costumeiras nos países do oriente. Assim, não há que se falar em universalidade de tais decisões.

${ }^{362}$ TESCARI, Adriana Sader. Violência sexual contra a mulher em situação de conflito armado, p. 84.

${ }^{363}$ A organização internacional Women's Initiatives for Gender Justice visa proteger os direitos humanos das mulheres, com um trabalho global para garantir justiça e uma atuação independente e efetiva do Tribunal Penal Internacional. Disponível em: <http://www.iccwomen.org/index.php>. Acesso em: 1 dez. 2011.

${ }^{364}$ ZORILLA, Maider. La Corte Penal Internacional ante el crimen de violencia sexual, p. 27.
} 
quando possível. Em que pese algumas divergências entre o estipulado no Estatuto de Roma e na legislação brasileira, segundo Fábio Bechara ${ }^{365}$ não há que se falar em incompatibilidade. Quando a justiça nacional atuar, o direito aplicável será o interno, quando a justiça penal internacional atuar é o direito internacional que deverá ser aplicado.

O tráfico de pessoas é considerado pela comunidade internacional como violação dos direitos fundamentais, e foi tutelado pelo Tribunal Penal Internacional como crime contra a humanidade, nos termos do art. $7^{\circ}$ do Estatuto de Roma ${ }^{366}$.

\begin{abstract}
“Art. $7^{\circ}$ - Crimes contra a humanidade
1. Para os efeitos do presente Estatuto, entende-se por "crime contra a humanidade", qualquer um dos atos seguintes, quando cometido no quadro de um ataque, generalizado ou sistemático, contra qualquer população civil, havendo conhecimento desse ataque: [...] c) Escravidão; [...] g) Agressão sexual, escravatura sexual, prostituição forçada, gravidez forçada, esterilização forçada ou qualquer outra forma de violência no campo sexual de gravidade comparável; [...] k) Outros atos desumanos de caráter semelhante, que causem intencionalmente grande sofrimento, ou afetem gravemente a integridade física ou a saúde física ou mental.

2. Para efeitos do parágrafo $1^{\circ}$ : a) Por "ataque contra uma população civil" ${ }^{367}$ entende-se qualquer conduta que envolva a prática múltipla de atos referidos no parágrafo $1^{0}$ contra uma população civil, de acordo com a política de um Estado ou de uma organização de praticar esses atos ou tendo em vista a prossecução dessa política; [...] c) Por "escravidão" entende-se o exercício, relativamente a uma pessoa, de um poder ou de um conjunto de poderes que traduzam um direito de propriedade sobre uma pessoa, incluindo o exercício desse poder no âmbito do tráfico de pessoas, em particular mulheres e crianças;". (grifos nossos)
\end{abstract}

$\mathrm{O}$ art. $8^{\circ}$ do Estatuto de Roma, que dispõe sobre os crimes de guerra, embora não utilize a expressão "tráfico de pessoas", também tutela as agressões sexuais.

\title{
"Art. $8^{\circ}$ - Crimes de Guerra
}

1. O Tribunal terá competência para julgar os crimes de guerra, em particular quando cometidos como parte integrante de um plano ou de uma política ou como parte de uma prática em larga escala desse tipo de crimes.

2. Para os efeitos do presente Estatuto, entende-se por "crimes de guerra": [...] b) Outras violações graves das leis e costumes aplicáveis em conflitos armados internacionais no âmbito do direito internacional, a saber, qualquer um dos seguintes atos: [...] xxii) Cometer atos de violação, escravidão sexual, prostituição forçada, gravidez à força, tal como definida na alínea $f$ ) do parágrafo $2^{\underline{0}}$ do artigo $7^{\circ}$, esterilização à força e qualquer outra forma de violência sexual que constitua também um desrespeito grave às Convenções de

\footnotetext{
${ }^{365}$ BECHARA, op. cit., p. 110-111.

${ }^{366}$ Promulgado pelo Decreto n. 4.388, de 25-9-2002.

367 Segundo Adriana Tescari, op. cit., p. 95, o termo "ataque contra uma população civil" foi definido restritivamente, o que dificulta a responsabilização por agressões sexuais, pois estas não ocorrem de forma organizada, além de serem de difícil comprovação, já que esse tipo de violência com frequência não é denunciado pelas vítimas em razão do estigma social e do medo de retaliação.
} 
Genebra; [...] e) As outras violações graves das leis e costumes aplicáveis aos conflitos armados que não têm caráter internacional, no quadro do direito internacional, a saber qualquer um dos seguintes atos: [...] vi) Cometer atos de agressão sexual, escravidão sexual, prostituição forçada, gravidez à força, tal como definida na alínea $f$ do parágrafo $2^{\circ}$ do artigo $7^{\circ}$; esterilização à força ou qualquer outra forma de violência sexual que constitua uma violação grave do artigo $3^{\circ}$ comum às quatro Convenções de Genebra; [...]”.

Uma distinção se faz necessária entre a prostituição forçada e a escravidão sexual. A primeira é a coação ao ato sexual realizada de forma contínua, usualmente em local estabelecido para tal finalidade. Ao contrário da escravidão sexual, em que há o exercício do direito de propriedade, na prostituição forçada existe a submissão a reiterados atos de violência sexual por meio de coerção ${ }^{368}$. Segundo Maider Zorrilla ${ }^{369}$, no momento da elaboração do Estatuto de Roma , foi muito difícil definir separadamente esses dois delitos, pois eles compartilham muitos de seus elementos constitutivos, como a obtenção de uma vantagem pecuniária ou de outro tipo. No caso concreto a subsunção da conduta a um desses delitos será ainda mais árdua.

Não obstante as definições acima, cabe aqui a crítica de Maria Elizabeth Queijo e João Daniel Rassi ${ }^{370}$, pois embora a finalidade da tutela do Tribunal seja justamente a dignidade humana, contraditoriamente nem todas as condutas tipificadas pelo Estatuto apresentam definição nos moldes exigidos pelo princípio da taxatividade, que é um dos corolários do princípio da legalidade. O mesmo ocorre com a ausência da determinação prévia da pena. No caso específico da definição do tráfico de pessoas, o Protocolo de Palermo se apresenta como fonte.

\footnotetext{
${ }^{368}$ TESCARI, op. cit. p. 85.

${ }^{369}$ ZORILLA, op. cit., p. 71.

${ }^{370}$ QUEIJO, Maria Elizabeth; RASSI, João Daniel. Tráfico internacional de pessoas e o Tribunal Penal Internacional. In: MARZAGÃO JÚNIOR, Laerte (coord.). Tráfico de pessoas, p. 241-242.
} 
Segundo as Regras de Procedimento e Prova ${ }^{371}$ do TPI, nos casos de violência sexual o consentimento será considerado irrelevante quando a capacidade de consentir da vítima tenha sido afetada pelo emprego de ameaça, força, coação, ou quando a vítima for incapaz .

Conforme conclui Fábio Bechara ${ }^{372}$, existem três situações possíveis quanto à competência para o julgamento do crime de tráfico de pessoas. A primeira delas é a regra geral, ou seja, prevalece a competência do Estado em que o crime foi cometido. Há também a possibilidade de a justiça nacional originariamente competente, de forma deliberada ou provocada, dar causa à impunidade. Nesse caso, com base no princípio da universalidade da jurisdição, qualquer Estado poderá julgar a conduta, desde que a ordem interna não disponha de forma diversa (no Brasil aplica-se o art. $7^{\circ}$, II, $a$, e $\S \S 2^{\circ}$ e $3^{\circ}$ do Código Penal). Por fim, se a conduta praticada configurar crime internacional, o crime poderá ser julgado pelo Tribunal Penal Internacional, desde que o Estado seja signatário do Estatuto de Roma, respeitado o princípio da complementariedade. Ou seja, o TPI somente poderá julgar os casos em que o Estado-Parte for omisso, parcial ou desidioso, e atender aos requisitos de um crime tipificado em seu Estatuto. Atualmente não há nenhum caso de tráfico sendo julgado pelo Tribunal ${ }^{373}$.

Em sentido contrário, Maíra Machado ${ }^{374}$ vê o tráfico de pessoas como um crime transnacional, e não internacional. A autora afirma que, embora o delito comporte violação de direitos e garantias individuais, a estratégia de responsabilização elaborada

\section{1 "Regla 70 - Principios de la prueba en casos de violencia sexual}

En casos de violencia sexual, la Corte se guiará por los siguientes principios y, cuando proceda, los aplicará:

a) El consentimiento no podrá inferirse de ninguna palabra o conducta de la víctima cuando la fuerza, la amenaza de la fuerza, la coacción o el aprovechamiento de un entorno coercitivo hayan disminuido su capacidad para dar un consentimiento voluntario y libre;

b) El consentimiento no podrá inferirse de ninguna palabra o conducta de la víctima cuando ésta sea incapaz de dar un consentimiento libre;

c) El consentimiento no podrá inferirse del silencio o de la falta de resistencia de la víctima a la supuesta violencia sexual;

d) La credibilidad, la honorabilidad o la disponibilidad sexual de la víctima o de un testigo no podrán inferirse de la naturaleza sexual del comportamiento anterior o posterior de la víctima o de un testigo".

Reglas de Procedimiento y Prueba. Disponível em: <http://www.icc-cpi.int/NR/rdonlyres/F1E0AC1C-A3F34A3C-B9A7-B3E8B115E886/140167/Rules_of_procedure_and_Evidence_Spanish.pdf $>$. Acesso em: 1 jan. 2012.

372 BECHARA, op. cit., p. 115.

373 Relação dos casos julgados atualmente pelo TPI: Disponível em: <http://www.icccpi.int/Menus/ICC/Situations+and+Cases/>. Acesso em: $30 \mathrm{dez} .2011$.

${ }^{374}$ MACHADO, Maíra Rocha. A assistência jurídica no Brasil. In: LANDINI, Tatiana Savoia; OLIVEIRA, Marina P. P. (org.). Enfrentamento ao tráfico de pessoas, p. 79-80. 
internacionalmente para lidar com essa atividade privilegia seu aspecto transnacional. $\mathrm{Ou}$ seja, a repressão penal constitui o eixo central de sua estratégia de enfrentamento, como acontece com outros crimes como o tráfico de drogas e armas, o financiamento do terrorismo, a lavagem de dinheiro, o crime organizado e a corrupção, que em regra envolvem movimento transfronteiriço e produção de riqueza. Assim, não seria tratado como os crimes internacionais, que tem como foco a proteção aos direitos humanos, incluindo crimes como a discriminação racial, a tortura, o genocídio, etc., podendo ser punidos pelo Tribunal Penal Internacional quando os países diretamente envolvidos não puderem ou não quiserem puni-los.

O que é pacífico é que o tráfico internacional de pessoas é um crime que não se esgota em um só país e, assim, exige a cooperação entre os Estados entre si, ou entre Estados e o TPI, para que haja a adequada responsabilização dos envolvidos e proteção das vítimas.

O tráfico tratado no Protocolo de Palermo é o transnacional (art. $4^{\circ}$ ), no sentido de que extrapola o território de um ou mais Estados. Conforme definição da Convenção de Palermo (art. $\left.3^{\circ}, 2\right)$, terá caráter transnacional o crime quando: a) for cometido em mais de um Estado; b) for cometido num só Estado, mas uma parte substancial da sua preparação, planejamento, direção e controle tenha lugar em outro Estado; c) for cometido num só Estado, mas envolva a participação de um grupo criminoso organizado que pratique atividades criminosas em mais de um Estado; ou d) for cometido num só Estado, mas produza efeitos substanciais noutro Estado.

Segundo Fábio Bechara ${ }^{375}$, cooperação jurídica internacional pode ser definida como "o conjunto de atos que regulamenta o relacionamento entre dois Estados ou mais, ou ainda entre Estados e Tribunais internacionais, tendo em vista a necessidade gerada a partir das limitações territoriais de soberania". Quando a cooperação é entre Estados, ocorre de forma horizontal e baseada no consenso. Já a cooperação entre os Estados e os Tribunais internacionais é de caráter vertical e obrigatório.

\footnotetext{
375 BECHARA, Fábio Ramazzini. Cooperação jurídica internacional em matéria penal: eficácia da prova produzida no exterior, p. 42.
} 
A Convenção de Palermo prevê as formas de cooperação que deverão ser utilizadas no delito de tráfico de pessoas. São elas: extradição (art. 16), transferência de pessoas condenadas (art. 17), assistência judiciária recíproca (art. 18), investigações conjuntas (art. 19), transferência de processos penais (art. 21), dentre outras.

Para Maíra Machado ${ }^{376}$, o Brasil recepcionou o modelo de assistência jurídica previsto na Convenção de Palermo, que é aplicável ao enfrentamento do tráfico de pessoas, sendo que esse instrumento favorece a utilização do auxílio direto e a atuação da autoridade central, ambos plenamente operativos no Brasil.

${ }^{376}$ MACHADO, op. cit., p. 84-86. 


\section{ANÁLISE CRÍTICA DA LEGISLAÇÃO BRASILEIRA REFERENTE AO TRÁFICO DE PESSOAS}

Apresentar-se-á neste capítulo um comparativo entre os Protocolos à Convenção de Palermo e o Código Penal brasileiro e a legislação esparsa sobre a matéria. São muitas as diferenças, como, por exemplo, a finalidade do tráfico de pessoas que no Protocolo de Palermo assume uma estrutura mais ampla, incluindo além da exploração sexual, outras formas de exploração, como o trabalho forçado ou a remoção de órgãos.

Segundo Adriana Piscitelli ${ }^{377}$ as diferentes definições de tráfico de pessoas têm consequências na produção de conhecimento sobre o tema. Assim, enquanto o Judiciário apresenta decisões pautadas no conceito do art. 231 do Código Penal, que exclui o consentimento, algumas ONGs que seguem o conceito do Protocolo de Palermo só classificam como tráfico a ação que envolve violência, coação ou fraude. A autora cita ainda casos em que os dois conceitos são utilizados indistintamente no mesmo documento.

Tendo em vista essas diferenças, será feita também uma análise das principais propostas de alteração da legislação em vigor para verificar se estão no mesmo sentido da agenda internacional para o tema.

Finalmente, será avaliada a abrangência criminal do tráfico de pessoas, que se apresenta como um verdadeiro fenômeno, e não apenas um tipo penal.

\subsection{LEGISLAÇÃO PENAL BRASILEIRA $x$ PROTOCOLOS ADICIONAIS À CONVENÇÃO DE PALERMO: A OBRIGAÇÃO DE CRIAR TIPOS PENAIS E AS PROPOSTAS PARA A ALTERAÇÃO DA LEGISLAÇÃO BRASILEIRA}

O Protocolo de Palermo indica as linhas de atuação a serem adotadas nos países para o enfrentamento ao tráfico de pessoas, mas não como uma fórmula pronta para ser

\footnotetext{
377 PISCITELLI, Adriana. Entre as "máfias" e a "ajuda": a construção de conhecimento sobre tráfico de pessoas. Cadernos Pagu, p. 42.
} 
aplicada. A internalização da legislação internacional deve ser adaptada à realidade brasileira $^{378}$.

O Protocolo determina em seu art. $5^{\circ}$ que cada Estado-Parte deverá adotar medidas legislativas com o fim de estabelecer como infrações penais os atos descritos no art. $3^{\circ}$ do citado Protocolo.

$\mathrm{O}$ mencionado art. $3^{\circ}$, dispõe: “a) A expressão "tráfico de pessoas" significa o recrutamento, o transporte, a transferência, o alojamento ou o acolhimento de pessoas, recorrendo à ameaça ou uso da força ou a outras formas de coação, ao rapto, à fraude, ao engano, ao abuso de autoridade ou à situação de vulnerabilidade ou à entrega ou aceitação de pagamentos ou benefícios para obter o consentimento de uma pessoa que tenha autoridade sobre outra para fins de exploração. A exploração incluirá, no mínimo, a exploração da prostituição de outrem ou outras formas de exploração sexual, o trabalho ou serviços forçados, escravatura ou práticas similares à escravatura, a servidão ou a remoção de órgãos;".

Assim, tem-se uma série de condutas (recrutar, transportar, alojar ou acolher) que devem ser tipificados quando presentes os meios descritos (ex. ameaça, violência, rapto, fraude, abuso de autoridade ou situação de vulnerabilidade), e para o fim de exploração.

O Protocolo não define o que seja a exploração, mas deixa claro com o uso da expressão "no mínimo" que esse rol é meramente exemplificativo. Não inclui expressamente o tráfico com vistas a conflitos bélicos, que é uma triste realidade nos países asiáticos e africanos, com seus meninos soldados, por exemplo, mas isso não afasta a aplicação do Protocolo nestes $\operatorname{casos}^{379}$.

O Código Penal brasileiro não possui um dispositivo específico que reúna todas essas hipóteses. Porém, possui dispositivos esparsos que criminalizam algumas dessas

\footnotetext{
${ }^{378}$ SOARES, Inês Virgínia Prado. Plataforma nacional de enfrentamento ao tráfico de pessoas no Brasil. In: MARZAGÃO JÚNIOR, Laerte (coord.). Tráfico de pessoas, p. 152.

${ }^{379}$ Segundo Zulita Fellini: "La trata o tráfico de niños se ejerce también com intención de hacerlos participar em conflictos de guerra, u obtener su sangre, o utilizarlos para intervenir en cultos de sectas secretas. Se sabe de la existencia de niños soldados y de niños secuestrados en conflictos bélicos". In: Delito de trata o tráfico de niños, p. 89.
} 
condutas. Vejamos a seguir quais são esses dispositivos; se estão de acordo com a proposta do Protocolo de Palermo; e, também, o que ainda deve ser criminalizado em nosso país.

O primeiro artigo a ser mencionado encontra-se no Título I da Parte Geral, que trata dos crimes contra as pessoas, no Capítulo VI, crimes contra a liberdade individual. É o art. 149 - redução a condição análoga à de escravo. A pena para esse crime é a reclusão de 2 a 8 anos e multa. Esse dispositivo foi alterado pela Lei n. 10.803, de 2003, visando aumentar seu âmbito de aplicação. Contudo, em mais um exemplo de legislação malelaborada, o resultado decorrente da nova tipificação restringiu o alcance do dispositivo. $\mathrm{O}$ crime que era comum foi transformado em crime especial quanto ao sujeito passivo, exigindo deste uma relação ou um vínculo trabalhista com o sujeito ativo. Além disso, o modo de execução, que antes era livre, agora, somente pode ser praticado segundo as formas previstas no caput e seu $\S 1^{\mathbf{o} 380}$.

No Título IV, que dispõe sobre os crimes contra a organização do trabalho, encontramos outros tipos penais relacionados à matéria. $\mathrm{O}$ primeiro deles é o art. 206 aliciamento para fim de emigração. A pena para esse delito é a detenção de 1 a 3 anos e multa, para a conduta de recrutar trabalhadores, mediante fraude, com o fim de levá-los para território estrangeiro.

Em seguida apresenta-se o art. 207 - aliciamento de trabalhadores de um local para outro do território nacional. A pena é a mesma do art. 206, mas o trânsito se dá no território nacional. Ainda no Título IV, podemos citar o art. 197 - atentado contra a liberdade de trabalho, ou art. 203 - frustração de direito assegurado por lei trabalhista, que poderiam ser utilizados subsidiariamente ou em concurso de crimes.

No Título VI, que dispõe sobre os crimes contra a dignidade sexual, no Capítulo V, referente ao lenocínio e ao tráfico de pessoas encontramos os dois tipos relacionados à matéria. $\mathrm{O}$ art. 231 - tráfico internacional de pessoa para fim de exploração sexual, apena com reclusão de 3 a 8 anos aquele que promove ou facilita a entrada no território nacional de alguém que venha exercer a prostituição ou outra forma de exploração sexual, ou que promove ou facilita a saída de alguém que vá se prostituir no exterior. Nessa

\footnotetext{
${ }^{380}$ Nesse sentido: Cezar Roberto Bitencourt, Tratado de direito penal, v. 2, p. 436, e Celso Delmanto, Código Penal Comentado, p. 532.
} 
mesma pena incorre aquele que agenciar, aliciar, comprar, transportar, transferir ou alojar a pessoa traficada. Embora esse dispositivo tenha sofrido duas reformas recentes, em 2005 e 2009, ainda não está totalmente de acordo com o disposto no Protocolo de Palermo.

O outro dispositivo é o art. 231-A - tráfico interno de pessoa para fim de exploração sexual. O tráfico interno segue os mesmos termos do tráfico internacional, porém sua pena é menor: reclusão de 2 a 6 anos.

No tocante ao tráfico visando à prostituição ou a exploração sexual, não sendo possível a configuração nos termos dos arts. 231 e 231-A, a conduta poderia ser tipificada com base em outros delitos, como mediação para servir à lascívia de outrem - art. 227, favorecimento da prostituição - art. 228, manter estabelecimento onde ocorra exploração sexual - art. 229, e rufianismo - art. 230. Contudo, a pena para esses crimes é inferior, variando de 1 a 5 anos de reclusão, considerando a figura do caput.

No Título VII, dos crimes contra a família, encontramos no Capítulo III, dos crimes contra a assistência familiar, a seguinte figura típica: art. $245, \S \mathbf{1}^{\mathbf{0}}$ - entrega de filho menor a pessoa inidônea. A conduta do caput - entregar filho menor de 18 anos a pessoa em cuja companhia saiba ou deva saber que o menor fica moralmente em perigo - é apenada com detenção de 1 a 2 anos. $O \S 1^{\circ}$ eleva essa pena para reclusão de 1 a 4 anos se o agente pratica o delito para obter lucro, ou se o menor é enviado para o exterior.

$\mathrm{Na}$ legislação esparsa, podemos citar inicialmente o Estatuto da Criança e do Adolescente (Lei n. 8.069, de 1990). O art. 239 dispõe sobre o envio de criança ou adolescente para o exterior com inobservância das formalidades legais ou com o fito de obter lucro, apenado com reclusão de 4 a 6 anos. Note-se que neste caso não se exige que a vítima fique exposta a qualquer tipo de perigo ou exploração. O art. 244-A apena com reclusão de 4 a 10 anos aquele que submeter criança ou adolescente à prostituição ou à exploração sexual.

Outra norma que deve ser mencionada é a Lei n. 9.434, de 1997, referente à remoção de órgãos para fins de transplante ou tratamento. Podemos citar, em especial, dois dispositivos que tratam da mercancia de órgãos. $\mathrm{O}$ art. $\mathbf{1 4}, \S \mathbf{1}^{\mathbf{0}}$, pune com reclusão de 3 a 8 anos e multa, aquele que remover tecidos, órgãos ou partes do corpo de pessoa ou 
cadáver, em desacordo com as disposições legais, mediante paga ou promessa de recompensa ou por outro motivo torpe. O art. 15 dispõe sobre a compra ou venda de tecidos, órgãos ou partes do corpo humano ${ }^{381}$, com pena de reclusão de 3 a 8 anos e multa.

Tendo em vista que o âmbito de aplicação do Protocolo de Palermo inclui apenas os delitos de natureza transnacional e que envolva grupo criminoso organizado, vamos avaliar quais dos dispositivos supramencionados poderiam ser utilizados.

Os arts. 206 (aliciamento para o fim de emigração), 231 (tráfico internacional de pessoa para fim de exploração sexual) e $245, \S 1^{\circ}$ (entrega de filho menor a pessoa inidônea), todos do Código Penal, e o art. 239 do Estatuto da Criança e do Adolescente (tráfico internacional de crianças e adolescentes) podem ser considerados transnacionais, porém independem do envolvimento de uma organização criminosa para sua configuração. E, de todos esses, apenas o art. 231 do Código Penal trata da exploração, embora não haja necessidade de sua ocorrência para a consumação do crime ${ }^{382}$.

Do exposto temos que a legislação brasileira não tipifica criminalmente o tráfico internacional de pessoas para as outras modalidades de exploração previstas no Protocolo de Palermo ${ }^{383}$. Ou seja, embora criminalize a redução a condição análoga à de escravo (art. 149 do código Penal) e o comércio de órgãos (art. 15 da Lei n. 9.434/1997), não o faz nos termos do diploma internacional.

O Protocolo relativo ao tráfico de migrantes determina, em seu art. $6^{\circ}$, que cada Estado-Parte deverá adotar medidas legislativas com o fim de estabelecer como infrações penais o tráfico de migrantes e os delitos correlatos.

\footnotetext{
${ }^{381}$ Sobre a comercialização de órgãos Claus Roxin afirma que a violação à ética e à dignidade humana não são suficientes para a punição. Posicionamento completo do autor em: Que comportamentos pode o Estado proibir sob ameaça de pena? Sobre a legitimação das proibições penais. In: ROXIN, Claus. Estudos de direito penal, p. 40-42.

382 No tocante à consumação: Alberto Silva Franco e Tadeu Dix Silva, op. cit., p. 1.143; Cezar Roberto Bitencourt, op. cit., p. 186. Em sentido contrário Guilherme Nucci, op. cit., p. 161.

${ }^{383}$ Nesse sentido Ela Wiecko V. Castilho, In: A legislação penal brasileira sobre tráfico de pessoas e imigração ilegal/irregular frente aos Protocolos adicionais à Convenção de Palermo. Disponível em: $<$ http://pfdc.pgr.mpf.gov.br/informacao-e-comunicacao/informativos-pfdc/edicoes-de-2006/maio-

2006/seminario_cascais.pdf/view>. Acesso em: 16 nov. 2010.
} 
Analisando a legislação brasileira podemos citar apenas dois dispositivos. O primeiro deles é o art. 309 do Código Penal - fraude de lei sobre estrangeiros. O caput desse artigo dispõe sobre o uso pelo estrangeiro de nome que não é o seu para entrar ou permanecer no território nacional, com pena de detenção de 1 a 3 anos. Já o parágrafo único tipifica a conduta de atribuir a estrangeiro falsa qualidade para promover-lhe a entrada em território nacional, com pena de reclusão de 1 a 4 anos.

O outro dispositivo é o art. 125 da Lei. 6.815, de 1980, Estatuto do Estrangeiro. Esse artigo traz inúmeras infrações penais e administrativas. Dentre elas, podemos citar o inciso XII - introduzir estrangeiro clandestinamente ou ocultar estrangeiro irregular, apenado com detenção de 1 a 3 anos.

Conforme lição de Ela Wiecko Castilho ${ }^{384}$ esses dispositivos não contemplam o fim de lucro, ao contrário do previsto no Protocolo. Concluímos, assim, que o tráfico de migrantes não é criminalizado no Brasil. Neste passo, os casos levados ao Judiciário relativos à emigração de brasileiros acabam definidos como crimes de quadrilha ou bando ou falsificação de documentos.

Do exposto, conforme Luiz Carlos Gonçalves ${ }^{385}$ houve omissão do País no cumprimento do mandado internacional de criminalização. Para Flávia Piovesan ${ }^{386}$, cabe ao Brasil elaborar todas as disposições de direito interno que sejam necessárias para tornar efetivos os direitos e liberdades enunciados nos tratados de que o Brasil é parte. Segundo a autora, a omissão estatal viola obrigação jurídica assumida no âmbito internacional, importando em responsabilização do Estado ${ }^{387}$.

${ }^{384}$ CASTILHO, Ela Wiecko V. A legislação penal brasileira sobre tráfico de pessoas e imigração ilegal/irregular frente aos Protocolos adicionais à Convenção de Palermo. Disponível em: $<$ http://pfdc.pgr.mpf.gov.br/informacao-e-comunicacao/informativos-pfdc/edicoes-de-2006/maio2006/seminario_cascais.pdf/view>. Acesso em: 16 nov. 2010.

${ }^{385}$ GONÇALVES, Luiz Carlos dos Santos. O tráfico de seres humanos como crime hediondo em sentido material. In: MARZAGÃO JÚNIOR, Laerte (coord.). Tráfico de pessoas, p. 188-192.

${ }_{386}^{3}$ PIOVESAN, Flávia. Direitos humanos e o direito constitucional internacional, p. 380.

${ }^{387}$ Maíra Rocha Machado afirma que as disposições constantes em tratados e convenções, por se apresentarem amplas e genéricas dificultam sua caracterização como obrigações internacionais aptas a gerarem a responsabilização dos Estados, seja pela ausência de incorporação ao ordenamento jurídico interno ou pela violação dessas obrigações pela própria conduta estatal. Além disso, a responsabilidade estatal pela ausência de prevenção, cooperação e repressão de crimes definidos em convenções internacionais não dispõe de um regime uniforme e preciso. In: MACHADO, Maíra Rocha. O plano local e supraestatal de gestão de problemas e conflitos internacionais: o direito moderno em face da internacionalização do campo jurídico, $\mathrm{p}$. 32 e 34 . 
No caso específico do Protocolo de Palermo, a criminalização do tráfico é visto como um requisito plenamente obrigatório a seus signatários, conforme disposto no Guia $^{388}$ Legislativo para a sua implementação, elaborado pelo UNODC. Tendo em vista uma interpretação literal, observa-se que o Protocolo foi redigido originalmente em inglês, e o verbo utilizado para determinar a criminalização foi shall, com a conotação de exprimir uma ordem.

Em que pese um avanço no enfrentamento ao tráfico de pessoas no Brasil nos últimos anos, entende-se que, independente de eventual responsabilização, a legislação brasileira precisa ser alterada, conforme previsto na agenda internacional. Porém, devendo respeitar uma adequada sistematização e o princípio da proporcionalidade para os delitos relacionados ao tráfico de pessoas e também de contrabando de migrantes. Nesse sentido, Ela Wiecko Castilho ${ }^{389}$ conclui que as inadequações na legislação vigente "ocorrem na definição dos tipos penais, ou seja, nos verbos que constituem o núcleo, nos sujeitos passivos, no objeto jurídico e, ainda, na coerência entre as penas"390.

Segundo o Guia Legislativo do UNODC, devem ser tomadas precauções na transposição ipsis verbis das disposições do Protocolo para o direito nacional, que exige níveis mais elevados de clareza e precisão para permitir a sua aplicação pelos tribunais. Além disso, o Guia recomenda aos legisladores de cada país que verifiquem as definições de crimes já existentes no direito interno, antes de se basearem nas formulações ou na terminologia do Protocolo.

Essas recomendações parecem óbvias, contudo, Zaffaroni ${ }^{391}$, ao se referir às alterações da legislação argentina face ao Protocolo de Palermo, tece duras críticas aos

\footnotetext{
${ }^{388}$ Guia Legislativo para a Implementação do Protocolo Adicional à Convenção das Nações Unidas contra a Criminalidade Organizada Transnacional relativo à Prevenção, à Repressão e à Punição do Tráfico de Pessoas, em especial de Mulheres e Crianças. Disponível em: <http://www.gddc.pt/cooperacao/materiapenal/textos-mpenal/onu/GuiaProtMulheres.pdf>. Acesso em: 15 jul. 2011.

${ }^{389}$ CASTILHO, op. cit.

${ }^{390}$ Em sentido contrário: Romeu Tuma Junior, enquanto Secretário Nacional de Justiça, afirmava que “a evolução legislativa brasileira, em adequação às previsões do Protocolo [...] permitiu ao país um aparelhamento jurídico capaz de combater o crime em sua forma mais extensa; na medida em que define, de forma ampla, as mais diversas formas de exploração da pessoa humana". TUMA JÚNIOR, Romeu. A política e o plano nacional de enfrentamento ao tráfico de pessoas. In: MARZAGÃO JÚNIOR, Laerte (coord.). Tráfico de pessoas. p. 274-275.

${ }^{391}$ ZAFFARONI, Eugênio Raúl. Prólogo. In: NIREMPERGER, Zunilda; RONDAN; Francisco. Mercaderes de vida: una visión histórica, sociológica y jurídica del delito de trata de personas, p. 11-12.
} 
procedimentos de internalização das normas internacionais pelo País ${ }^{392}$. Segundo o autor, os costumes atuais fazem com que o texto dos tratados sejam convertidos em leis penais letra por letra -, quando o correto seria ajustar as leis penais existentes aos tratados internacionais. Como resultado surgem dupla ou tripla tipificação de condutas, tipos penais com conceitos vagos e até mesmo incompreensíveis etc. $\mathrm{O}$ autor não se opõe a alteração, mas sim à forma como ela é feita.

Paz Lloria García ${ }^{393}$ também critica a internalização do Protocolo na Espanha, que, segundo a autora, foi feita de forma acrítica, sem levar em conta as especificidades do País, o que deu margem a uma fórmula legal imprecisa e excessivamente ampla.

Nesse sentido, Maíra Rocha Machado ${ }^{394}$ afirma que os tratados e convenções relacionados à matéria penal exprimem um consenso mínimo de um grupo de países no tocante a temas específicos, sobre os quais se elaboram pautas de atuação de uma amplitude tal que a aplicação direta de suas disposições é raramente possível, cabendo ao Poder Legislativo a adequada elaboração ou modificação da legislação existente.

O enfrentamento ao tráfico de pessoas é mister que encontra respaldo constitucional por estar diretamente ligado com a obrigação estatal de proteção dos direitos humanos no território brasileiro. Porém, o legislador deve criminalizar as condutas com parcimônia, de acordo com as necessidades do País.

As duas modificações referentes ao crime de tráfico foram realizadas pelas Leis n. 11.106, de 2005, e n. 12.015, de 2009. A primeira se originou do Projeto de Lei n. 117, apresentado em 2003 pela Deputada Iara Bernardi. O projeto original visava apenas à retirada da expressão mulher honesta do então Título dos Crimes contra os Costumes, bem como alterar para tráfico de pessoas o então tráfico de mulheres. Contudo, o projeto foi aprovado na forma de substitutivo alterando muitos outros dispositivos. Interessam-nos as

\footnotetext{
392 O artigo do Código Penal argentino objeto da crítica do autor é o seguinte: “Artículo 145 bis: El que captare, transportare o trasladare, dentro del país o desde o hacia el exterior, acogiere o recibiere personas mayores de dieciocho años de edad, cuando mediare engaño, fraude, violencia, amenaza o cualquier otro medio de intimidación o coerción, abuso de autoridad o de una situación de vulnerabilidad, concesión o recepción de pagos o beneficios para obtener el consentimiento de una persona que tenga autoridad sobre la víctima, con fines de explotación, será reprimido con prisión de 3 a 6 años".

${ }^{393}$ BOIX REIG, Javier (dir.). Derecho penal: parte especial, p. 299.

${ }^{394}$ MACHADO, op. cit., p. 30.
} 
alterações no art. 231, que passa de tráfico de mulheres para tráfico internacional de pessoas, e o acréscimo do art. 231-A, que passa a dispor sobre o tráfico interno de pessoas, até então não tutelado pela legislação pátria. As alterações foram positivas, mas não suficientes.

A Lei n. 12.015, de 2009, decorreu do Projeto de Lei do Senado n. 253, de 2004, elaborado pela Comissão Parlamentar Mista de Inquérito - CPMI, criada em 2003, com a finalidade de investigar as situações de violência e redes de exploração sexual de crianças e adolescentes no Brasil, presidida pela Senadora Patrícia Saboya.

No tocante ao tráfico de pessoas, essa Lei alterou o nomen juris dos arts. 231 e 231A do Código Penal para tráfico internacional e interno de pessoa para fim de exploração sexual, respectivamente. Além disso, incluiu novas condutas típicas aos artigos mencionados, como agenciar, aliciar, comprar, transportar, transferir ou alojar a pessoa $\operatorname{traficada}^{395}$.

Assim, o enfoque até o momento foi dado ao tráfico de pessoas visando a prostituição ou a exploração sexual, sem mencionar as outras figuras previstas no Protocolo.

O Decreto n. 5.948, de 26-10-2006, que aprova a Política Nacional de Enfrentamento ao Tráfico de Pessoas, e o Decreto n. 6.347, de 8-1-2008, que aprova o Plano Nacional de Enfrentamento ao Tráfico de Pessoas - PNETP ${ }^{396}$, por sua vez, trazem uma abordagem mais ampla do tráfico de pessoas.

\footnotetext{
${ }^{395}$ As críticas a essa norma encontram-se no Capítulo 4.

${ }^{396}$ Nos termos do art. $1^{\circ}, \S 1^{\circ}$, deste Decreto, o PNETP deveria ser executado no prazo de dois anos. O Relatório Final de Execução do Plano Nacional de Enfrentamento do Tráfico de Pessoas apresenta os avanços alcançados no período de sua vigência, como o aumento do número de pesquisas, ampliação dos serviços de atendimento às vítimas, aumento do número de denúncias etc. Além disso, faz recomendações para o II PNETP (p. 253-256). A Portaria n. 749, de 29 de abril de 2010, do Ministério da Justiça, criou o Grupo de Trabalho para coordenação do processo de elaboração do II Plano Nacional de Enfrentamento ao Tráfico de Pessoas.
} 
Nos termos do art. $2^{\circ}$, caput, da Política Nacional ${ }^{397}$, adota-se o conceito "tráfico de pessoas" disposto no Protocolo de Palermo. Cabe aqui a ressalva de que o consentimento, previsto no $\S 7^{\circ}$ do referido artigo, é considerado irrelevante para a configuração do tráfico de pessoas, ao arrepio do estabelecido no Protocolo.

O PNETP, de 2008, estabelece uma série de prioridades, e a de n. 6 visa aperfeiçoar a legislação brasileira relativa ao enfrentamento ao tráfico de pessoas e crimes correlatos, uniformizando o conceito de tráfico de pessoas em consonância com a Política Nacional de Enfrentamento ao Tráfico de Pessoas, com o Protocolo de Palermo e com os Acordos internacionais ratificados pelo Brasil. De fato, houve um grupo de trabalho multidisciplinar ${ }^{398}$ discutindo os projetos de lei referentes ao tráfico de pessoas, visando adequá-lo ao Protocolo de Palermo em face da realidade brasileira. Porém, as agendas não caminharam no mesmo passo, e, durante esse processo, foi sancionada a Lei n. 12.015, de 2009, prejudicando o andamento dos projetos em análise. Os Projetos mencionados são: n. 2.375 e n. 2.845 , ambos de $2003^{399}$.

O PL n. 2.375, do Deputado Antonio Carlos Pannunzio, dentre outras proposições, sugeria a inclusão de um $\S 4^{\circ}$ ao art. 231 do Código Penal, que merece ser transcrito: " $\S 4^{\circ}$ - Na mesma pena do caput incorre quem promove, intermedia ou facilita a entrada ou saída do território nacional, com ou sem consentimento, de pessoa que seja submetida a trabalhos forçados, escravatura ou remoção de órgãos”.

Esse dispositivo deixa bem claro como a maior parte das leis é elaborada no Brasil, sem técnica ou sistematização. Como se aproveitar do então Título dos Crimes contra os

\footnotetext{
397 “Art. $2^{\circ}$ Para os efeitos desta Política, adota-se a expressão "tráfico de pessoas” conforme o Protocolo Adicional à Convenção das Nações Unidas contra o Crime Organizado Transnacional Relativo à Prevenção, Repressão e Punição do Tráfico de Pessoas, em especial Mulheres e Crianças, que a define como o recrutamento, o transporte, a transferência, o alojamento ou o acolhimento de pessoas, recorrendo à ameaça ou uso da força ou a outras formas de coação, ao rapto, à fraude, ao engano, ao abuso de autoridade ou à situação de vulnerabilidade ou à entrega ou aceitação de pagamentos ou benefícios para obter o consentimento de uma pessoa que tenha autoridade sobre outra para fins de exploração. A exploração incluirá, no mínimo, a exploração da prostituição de outrem ou outras formas de exploração sexual, o trabalho ou serviços forçados, escravatura ou práticas similares à escravatura, a servidão ou a remoção de órgãos".

${ }^{398}$ Informações colhidas nas degravações das reuniões do Grupo de Trabalho sobre Legislação de Tráfico de Pessoas, ao longo do ano de 2009. Material fornecido pelo Coordenador de Enfrentamento ao Tráfico de Pessoas do Ministério da Justiça - Ricardo Rodrigues Lins, via e-mail, em dez. 2010.

${ }^{399}$ O PL 2.375 encontra-se arquivado desde janeiro de 2011. O PL 2.845 está em tramitação.
} 
Costumes, para inserir a criminalização do tráfico para fim de exploração do trabalho ou remoção de órgãos?

O relator do PL n. 2.375 na CCJ da Câmara, propôs, em abril de 2010, a aprovação na forma de Substitutivo, alterando apenas o art. 239 do Estatuto da Criança e do Adolescente, ignorando assim os demais dispositivos.

O PL n. 2.845, de autoria dos Deputados Nélson Pellegrino e Orlando Fantazzini, adotou a mesma técnica do PL n. 2.375, incluindo todas as formas de tráfico no art. 231 do Código Penal. O parecer do relator do projeto na CCJ da Câmara, de outubro de 2009, propõe a aprovação na forma de Substitutivo, com a inclusão do tipo penal referente ao tráfico de seres humanos para remoção de órgãos, tecidos e partes do corpo humano no Título I do Código Penal, que trata dos Crimes Contra a Pessoa, em um capítulo específico - Dos crimes contra a dignidade da pessoa humana, silenciando quanto ao tráfico para fim de trabalho forçado.

Acredita-se que o legislador não poder perder a oportunidade de sistematizar a matéria se debruçando sobre projetos mal-elaborados. Conforme lição de Renato Silveira, a urgência das reformas não pode prescindir a reflexão acurada do tema, pois toda alteração legislativa deve ter "arcabouço doutrinário para um lastro devido"400. Não é de afogadilho que se resolverá a questão.

A criação da CPI do Tráfico de Pessoas, pelo Requerimento n. 226/2011, certamente resultará em alteração legislativa. A finalidade da CPI, presidida pela Senadora Vanessa Grazziotin, tem como escopo “investigar o tráfico nacional e internacional de pessoas no Brasil, suas causas, consequências, rotas e responsáveis, no período de 2003 e 2011, compreendido na vigência da Convenção de Palermo”. Em dezembro de 2011 a CPI elaborou um Relatório Parcial, que já alerta sobre a necessidade urgente de modificação do Código Penal, e apresentou um projeto de lei. Contudo, entendemos que a proposição é assistemática, pois inclui todas as formas de tráfico - para trabalho forçado, extração de órgãos etc. -, no Título VI da Parte Especial do Código Penal - Dos Crimes contra a Dignidade Sexual. O projeto prevê a alteração dos arts. 231 e 231-A do Código, e revoga

${ }^{400}$ SILVEIRA, op. cit., p. 58-59. 
seus arts. 206 e 207. Ao contrário da norma vigente, a redação sugerida exige a ocorrência de meios específicos, como violência, engano ou abuso de situação de vulnerabilidade, para a caracterização do delito, e assim se depreende que o consentimento válido será considerado. Porém, o projeto não aborda a migração ilegal, e questões como a punição pela efetiva exploração e pelo uso dos serviços de pessoa sabidamente traficada. Vejamos a proposta referente ao art. 231 (tráfico internacional):

\section{Título VI - Dos Crimes contra a Dignidade Sexual Capítulo V - DO LENOCÍNIO E DO TRÁFICO DE PESSOA}

\section{Tráfico internacional de pessoa}

Art. 231. Agenciar, aliciar, recrutar, transportar, transferir, alojar ou acolher pessoa, por meio de ameaça, coação ou qualquer forma de violência, sequestro ou cárcere privado, fraude, engano, abuso de autoridade ou prevalecendo-se de relações domésticas, de coabitação, de hospitalidade, de contrato ou de situação de vulnerabilidade, independentemente de entrega ou pagamento de valores ou benefícios, com o fim de promover ou facilitar a sua entrada em território nacional, ou a sua saída para o exterior, para exercer a prostituição ou outra forma de exploração sexual, trabalhar ou prestar qualquer forma de serviço, forçado ou não, ou ter órgão, tecido ou parte do corpo humano removidos: Pena - reclusão, de 4 (quatro) a 10 (dez) anos.

$\S 1^{\circ}$ Incorre na mesma pena quem pratica a conduta referida no caput deste artigo para outro fim que acarrete ofensa relevante à dignidade da pessoa ou à sua integridade física.

$\S 2^{\circ}$ A pena é aumentada de $1 / 2$ (metade) se a vítima é menor de 18 (dezoito) anos ou, por enfermidade, deficiência mental ou qualquer situação ou condição específica, não tem o necessário discernimento do fato.

$\S 3^{\circ}$ Se o crime é cometido com o fim de obter vantagem econômica, aplica-se também multa.

Alguns doutrinadores também apresentam propostas de alteração legislativa. A sugestão de alteração de Ela Wiecko Castilho ${ }^{401}$ prevê a criação de um tipo básico para o crime de tráfico de pessoas e tipos derivados conforme a finalidade da exploração. A proposta é baseada no Anteprojeto da Reforma da Parte Especial do Código Penal, de 1992, que criava um capítulo dos crimes contra a dignidade da pessoa humana, dentro do título referente aos crimes contra a pessoa. Além de outros delitos haveria neste capítulo a figura do tráfico de pessoas para fim de exploração sexual, trabalhos forçados, escravidão ou práticas similares a esta, servidão ou remoção de tecidos, órgãos ou partes do corpo humano.

Tadeu Dix Silva ${ }^{402}$ propõe a remodelação da figura penal do art. 231 do Código Penal. Segundo o autor o tipo deveria deslocar-se para um novo capítulo - Dos Crimes

${ }^{401}$ CASTILHO, op. cit.

${ }^{402}$ SILVA, Tadeu Dix. Crimes sexuais: reflexões sobre a nova Lei n. 11.106/2005, p. 319. 
contra a Dignidade da Pessoa Humana - integrante do título - Dos Crimes contra a Pessoa. A redação proposta é nos moldes do Protocolo de Palermo, que leva em conta o consentimento válido:

\title{
Tráfico de pessoas
}

Art. [...] - Promover ou facilitar a entrada, no território nacional, de pessoa que venha exercer a prostituição, ou sua saída, para exercê-la no estrangeiro, mediante o emprego de violência ou grave ameaça, ou outras formas de coação, ou abusando o agente de situação de superioridade, ou de vulnerabilidade, de condição econômica, de situação de abandono ou de necessidade da vítima.

Pena $[\ldots]$

Ter-se-ia, então, a dignidade humana como o principal bem jurídico tutelado. Neste passo, se ingressa em tormentoso caminho, pois, o que é a dignidade humana? Sabe-se que ela é assegurada por diplomas do peso da Declaração Universal dos Direitos do Homem ${ }^{403}$, de 1948, que, segundo Flávia Piovesan ${ }^{404}$, introduz a concepção contemporânea de direitos humanos, sendo a dignidade humana o seu fundamento; do Pacto de São José da Costa Rica $^{405}$, de 1969; e da Constituição Federal de $1988^{406}$.

Ingo Wolfgang Sarlet ${ }^{407}$, a despeito de ter elaborado um conceito para a dignidade humana, afirma que é tarefa muito difícil obter uma definição consensual, precisa e universalmente válida. Segundo o autor, a dignidade da pessoa humana é

\begin{abstract}
a qualidade intrínseca e distintiva reconhecida em cada ser humano que o faz merecedor do mesmo respeito e consideração por parte do Estado e da comunidade, implicando, neste sentido, um complexo de direitos e deveres fundamentais que assegurem a pessoa tanto contra todo e qualquer ato de cunho degradante e desumano, como venham a lhe garantir as condições existenciais mínimas para uma vida saudável, além de propiciar e promover sua participação ativa e corresponsável nos destinos da própria existência e da vida em comunhão com os demais seres humanos, mediante o devido respeito aos demais seres que integram a rede da vida. (grifos nossos)
\end{abstract}

Para se demonstrar a importância da dignidade humana, vale citar Inocêncio Mártires Coelho ${ }^{408}$, para quem a "dignidade da pessoa humana, porque sobreposta a todos

\footnotetext{
403 “Art. I - Todas as pessoas nascem livres e iguais em dignidade e direitos". (grifos nossos)

${ }^{404}$ PIOVESAN, Flávia. Temas de Direitos Humanos, p. 40.

405 “Art. 11, 1 - Toda pessoa tem direito ao respeito da sua honra e ao reconhecimento de sua dignidade". (grifos nossos). Promulgado no Brasil pelo Decreto n. 678, de 1992.

406 “Art. $1^{\circ}$ - A República Federativa do Brasil, formada pela união indissolúvel dos Estados e Municípios e do Distrito Federal, constitui-se em Estado Democrático de Direito e tem como fundamentos: [...] III - a dignidade da pessoa humana;". (grifos nossos)

${ }^{407}$ SARLET, Ingo Wolfgang. Dignidade da pessoa humana e direitos fundamentais, p. 67.

${ }^{408}$ MENDES, G. F.; COELHO, I. M.; BRANCO, P. G. G. Curso de direito constitucional, p. 174.
} 
os bens, valores ou princípios constitucionais, em nenhuma hipótese é suscetível de confrontar-se com eles, mas tão somente consigo mesma”.

No entendimento de Flávia Piovesan ${ }^{409}$, a dignidade humana simboliza um "superprincípio constitucional, a norma maior a orientar o constitucionalismo contemporâneo, dotando-lhe especial racionalidade, unidade e sentido".

Segundo José Luis Guzmán Dalbora ${ }^{410}$ a dignidade humana não é um bem jurídico. Para o autor é um equívoco confundir um atributo da pessoa com aqueles elementos que possibilitem sua conservação. Assim, para ele, no caso de tráfico para fim de exploração sexual, o verdadeiro objeto jurídico é a liberdade sexual do indivíduo.

Países como Portugal e Alemanha inserem o delito de tráfico de pessoas no capítulo referente aos crimes contra a liberdade. Portugal abrange em dispositivo único a exploração sexual, do trabalho e a extração de órgãos, e a Alemanha possui um dispositivo para a exploração sexual e outro para a exploração do trabalho.

Conforme leciona Vicente Greco Filho ${ }^{411}$, identificar o bem jurídico tutelado leva ao entendimento do dispositivo em seu significado substancial. Porém, o professor alerta que a classificação dos crimes, tendo em vista o bem jurídico, enfrenta dois problemas.

O primeiro deles diz respeito ao inter-relacionamento dos bens jurídicos, que, segundo o professor, se "agrupam em círculos concêntricos, secantes ou ambos" "412. Assim, existem os bens jurídicos nucleares, e, ao redor desses, gravitam bens jurídicos menos valiosos, os periféricos. Esses periféricos, no entendimento de Greco, servem de escudo ou blindagem para o bem jurídico nuclear.

O segundo problema a ser enfrentado é a existência de crimes pluriofensivos. Assim, como atingem mais de um bem jurídico, deve-se optar pelo bem jurídico mais

\footnotetext{
${ }^{409}$ PIOVESAN, op. cit., p. 424.

410 GUSMÁN DALBORA, José Luis. La trata de personas y el problema de su bien jurídico. Revista Brasileira de Ciências Criminais, p. 126, 139 e 140.

${ }^{411}$ GRECO FILHO, Vicente. Tipicidade, bem jurídico e lavagem de valores. In: COSTA, José de Faria; SILVA, Marco Antonio Marques da. Direito penal especial, processo penal e direitos fundamentais: visão Luso-Brasileira, p. 159-161.

${ }^{412}$ Idem, p. 160.
} 
importante ou predominante. Segundo Greco ${ }^{413}$, essa opção é influenciada pela ideologia e pela política criminal.

Mediante essas propostas de alteração, caberá ao legislador eleger em qual capítulo estará localizado esse crime, pois, segundo ensina Greco, “a classificação legal é uma indicação interpretativa relevante de ser considerada" ${ }^{\text {414. }}$.

Entende-se que existem alguns caminhos que poderiam ser seguidos pelo legislador. $O$ que se deve ter em vista é a prevalência do direito penal mínimo e a obediência ao princípio da proporcionalidade, além de uma correta sistematização da matéria.

Uma opção viável poderia ser a inserção de um tipo geral de tráfico de pessoas ao Código Penal, com vistas à proteção do bem jurídico liberdade individual. E, para cada finalidade de tráfico outros bens jurídicos seriam aventados, como a liberdade sexual, integridade física etc.

Assim, optando por proteger a liberdade, a dignidade humana seria respeitada. $\mathrm{O}$ exercício da liberdade pode ser considerado uma consequência da efetividade do superprincípio da dignidade humana.

O que não se pode olvidar é que o tráfico de pessoas não é uma questão que se esgota em dispositivos penais, pois se trata de um fenômeno muito mais complexo. Outra opção seria criar uma lei ordinária específica para esse tipo de tráfico, assim como ocorre com a Lei de Drogas (Lei n. 11.343/2006) e o Estatuto do Desarmamento (Lei n. 10.826/2003). Ambas cuidam do tráfico ilícito, e também de outras questões atinentes às respectivas matérias. Essa foi a opção da Argentina, por exemplo.

O UNODC ${ }^{415}$ elaborou um modelo de lei contra o tráfico de pessoas, com o intuito de ajudar os países a implementar as disposições contidas no Protocolo de Palermo. O modelo foi elaborado para ser adaptável às necessidades de cada nação, de acordo com sua

\footnotetext{
${ }^{413}$ GRECO FILHO, op. cit., p. 160.

${ }^{414}$ Idem, p. 160.

${ }^{415}$ Model Law against Trafficking in Persons. Disponível em: <http://www.unodc.org/documents/humantrafficking/UNODC_Model_Law_on_Trafficking_in_Persons.pdf>. Acesso em: 1 jan. 2012.
} 
tradição jurídico-legal, princípios constitucionais e condição social, econômica, cultural e geográfica. É sugerido um texto geral, um mosaico de excertos extraídos da legislação vigente em diversos países, do Protocolo e outros documentos internacionais, complementado por comentários e exemplos.

Conclui-se que o legislador brasileiro está em falta com a agenda internacional no tocante ao tráfico internacional de pessoas, mas alerta-se para o não engessamento daquele tendo em vista a legislação internacional. As normas devem ser estabelecidas de acordo com as necessidades e peculiaridades do País.

\subsection{ANÁlISE CRÍTICA DO CONCEITO LEGAL DE TRÁFICO INTERNACIONAL DE PESSOAS PARA FIM DE EXPLORAÇÃo SEXUAL: MAIS QUE UM CRIME, UM VERDADEIRO "FENÔMENO"}

O tráfico de pessoas é também denominado forma moderna de escravidão, escravidão contemporânea ou escravidão moderna, referindo-se ao tratamento dispensado à escravidão negra encerrada no século XIX.

Conforme afirma Pérez Alonso ${ }^{416}$, o que poderia parecer um simples "recurso literário" infelizmente é a expressão fiel da dura realidade de milhares de pessoas. A nova escravidão mantém alguns paralelos com a velha escravidão. $\mathrm{O}$ primeiro deles é o componente geográfico. No tráfico de pessoas sempre há deslocamento. Hoje, embora a predominância seja a transnacionalidade, existe também o tráfico interno, que ocorre entre as diversas regiões de um mesmo país.

A relação jurídica entre o negro e o senhor era legalmente reconhecida. Este podia exercer os direitos de propriedade sobre o escravo como se fosse um bem móvel. O escravo era um bem caro, que exigia um investimento alto, só acessível aos mais abastados. Hoje, a nova escravidão se desenvolve à margem da lei. Embora não seja mais uma relação legal, mas sim de fato, existem ainda pessoas que vivem como coisas, sob

${ }^{416}$ PÉREZ ALONSO, Esteban J. Consideraciones político-criminales sobre el fenómeno migratorio actual y el tráfico de personas. In: MIR PUIG, Santiago; CORCOY BIDASOLO, Mirentxu (dir.). Protección penal de los derechos de los trabajadores: seguridad en el trabajo, tráfico ilegal de personas e inmigración clandestina, p. 419-427. 
controle absoluto de outrem que as exploram economicamente. Além disso, um escravo hoje é muito mais barato, podendo custar míseros dólares ${ }^{417}$.

Ao contrário da escravidão negra, baseada em questões étnicas ou raciais, a escravidão contemporânea deita raízes na desigualdade social. A falta de oportunidades e a pobreza são fatores que criam um ambiente propício para o tráfico.

Assim como acontecia com a escravidão negra, as pessoas são submetidas a tratamento desumano e degradante, alijadas dos direitos mais fundamentais do ser humano, chegando a sua completa exclusão social. Os meios empregados para submeter a vítima a essa situação podem ser baseados em violência ou ameaça, no engodo ou abuso de uma situação de extrema necessidade ou vulnerabilidade.

Nesse contexto, a expressão "tráfico de pessoas" assume uma abrangência maior do que aquela dada pelo legislador brasileiro ou a disponível no Protocolo de Palermo.

O Código Penal tipifica como "tráfico de pessoas" a promoção ou a facilitação da entrada no território nacional de alguém que nele venha a exercer a prostituição ou outra forma de exploração sexual, ou a saída de alguém que vá exercê-la no estrangeiro. Outras condutas também são consideradas tráfico para o nosso Código: agenciar, aliciar, transportar, transferir, alojar ou comprar a pessoa traficada.

O Protocolo de Palermo define o tráfico de pessoas como o recrutamento, o transporte, a transferência, o alojamento ou o acolhimento de pessoas, recorrendo à ameaça ou uso da força ou a outras formas de coação, ao rapto, à fraude, ao engano, ao abuso de autoridade ou à situação de vulnerabilidade ou à entrega ou aceitação de pagamentos ou benefícios para obter o consentimento de uma pessoa que tenha autoridade sobre outra para fins de exploração.

Como se depreende dos textos mencionados, a exploração em si não é tutelada. Trata-se de exaurimento do delito de tráfico ou crime autônomo. Conforme dispõe Paulo José da Costa Júnior ${ }^{418}$, o crime de tráfico internacional de pessoas previsto no art. 231 do

${ }^{417}$ Sobre a questão veja o Capítulo 6.

${ }^{418}$ COSTA JÚNIOR, Paulo José. Curso de Direito Penal, p. 710-711. 
Código Penal refere-se à conduta daqueles que recrutam pessoas, em nosso país ou no estrangeiro, destinadas à prostituição ou outra forma de exploração. Segundo o autor, a função desses fornecedores é "trazer ou carregar a triste mercadoria".

Segundo Kara ${ }^{419}$, a definição correta para o tráfico de pessoas deveria ser “o processo de aquisição, recrutamento, acolhimento, compra ou transporte de um indivíduo, por qualquer meio e para qualquer distância, para uma condição de exploração da escravidão ou condição análoga à escravidão". E, escravidão pode ser definida como “o processo de coação de um indivíduo cativo para o trabalho ou outros serviços, por qualquer meio, incluindo a exploração do corpo ou de partes do corpo".

Kara $^{420}$ afirma que a primeira confusão no tocante à definição de tráfico de pessoas com propósito de exploração é saber se faz parte desse conceito a exploração em si. É um problema enfrentado em vários países do mundo, no Brasil inclusive. Segundo o autor ${ }^{421}$ o governo norte-americano tentou afastar essa confusão ao afirmar que não é necessário que haja "movimentação" para que seja configurado tráfico de pessoas.

Assim, o "crime de tráfico de pessoas" é a atividade ilícita que precede o "trabalho escravo", seja na forma de exploração sexual ou laboral. O art. 149 do Código Penal brasileiro tipifica a "redução a condição análoga à de escravo". Teríamos, então, concurso material de crimes entre os arts. 149 e 231 do Código. Existem outras possibilidades de concurso dentre os crimes contra a dignidade sexual ${ }^{422}$, como o estupro e os crimes de lenocínio.

Não se deve confundir, então, o "fenômeno do tráfico de pessoas", que é entendido com um processo delitivo que prevê desde o aliciamento, passando pelo transporte e

\footnotetext{
${ }^{419}$ KARA, Siddharth. Sex trafficking: inside the business of modern slavery, p. 5: "Slave trading can be defined as the process of acquiring, recruiting, harboring, receiving or transporting an individual, through any means and for any distance, into a condition of slavery or slave-like exploitation. Slavery can be defined as the process of coercing labor or other services from a captive individual, through any means, including exploitation of bodies or body parties". (tradução e grifo nossos)

${ }^{420}$ Idem, p. 4.

${ }^{421}$ Idem, p. 263. Cabe aqui a observação de que nos Estados Unidos a palavra "traffic" é utilizada para a escravidão contemporânea. Para a escravidão de negros era utilizada a expressão "slave trade", que é mais abrangente, vai além do "trânsito" ou "movimento" que se pode depreender de "human trafficking". Em espanhol prefere-se o "trata de personas" para descrever o fenômeno do tráfico de pessoas para fim de exploração, restando a palavra "tráfico" para o contrabando de migrantes, que envolve apenas "movimento".

${ }^{422}$ MIRABETE, Júlio Fabbrini; FABBRINI, Renato N. Código penal interpretado, p. 1.442.
} 
culminando com a efetiva exploração, com o "delito de tráfico de pessoas" conforme previsto no Código Penal, art. 231, que exige apenas a movimentação, sem se importar com a exploração da vítima para fins econômicos ${ }^{423}$.

$\mathrm{Kara}^{424}$ propõe um quadro para facilitar a visualização desse fenômeno. São dois componentes principais: o tráfico stricto sensu, que inclui o recrutamento e o transporte, e a escravização que corresponde à exploração.

\section{TRÁFICO SEXUAL}

ETAPAS

GEOGRAFIA

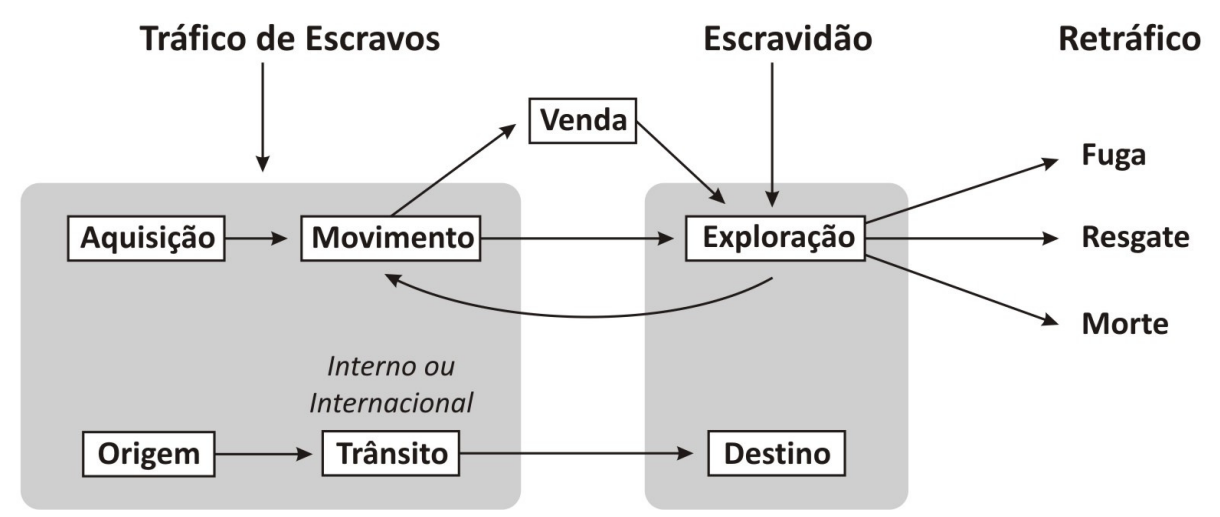

Para que o tráfico de pessoas se perfaça, várias outras condutas criminosas são realizadas. O recrutamento pode ocorrer mediante sequestro, compra ou aliciamento da pessoa que será traficada. Durante o transporte e a entrada no território estrangeiro poderá haver infração às normas de migração, corrupção de funcionários e uso de documentos falsos. A exploração pode incluir agressão física, estupro, tortura, ameaça, e até ocasionar a morte. Além disso, o grupo criminoso pode se enquadrar no conceito de quadrilha ou bando, que por si só já constitui crime. E, o lucro do negócio pode virar objeto de crime econômico, como "lavagem" de dinheiro, evasão fiscal etc. As condutas mencionadas são apenas a título ilustrativo, pois a complexidade do fenômeno que consiste o tráfico internacional de pessoas não pode ser verificada numerus clausus.

\footnotetext{
${ }^{423}$ Nesse sentido Siddharth Kara afirma que: "The wording connotes only the movement portion of the trafficking chain, which explains why so many laws and programs against trafficking focus on movement more than exploitation. However, trafficking is not about movement; it is about slavery. In: Sex Trafficking., p. 4.

${ }^{424}$ KARA, op. cit., p. 6. Figura original: Anatomy of sex trafficking (tradução nossa).
} 
O legislador precisa levar em consideração todas essas ações na elaboração do tipo penal. Conforme alerta $\mathrm{Kara}^{425}$, em muitos países a legislação contra o estupro, tortura e homicídio por ser mais rígida e efetiva do que aquela contra o tráfico sexual acaba sendo aplicada. E, assim, o tráfico se perpetua como um crime invisível.

Outro ponto a ser destacado é que existem poucas alternativas para as escravas sexuais. Sob forte coação física e psicológica muitas acabam aceitando a vida a que são submetidas, se transformam em adictas, se suicidam, são assassinadas ou morrem de doenças como a AIDS. Poucas conseguem fugir para abrigos ou são resgatadas. Quando isso acontece, muitas delas têm que retornar para as mesmas condições de pobreza, violência doméstica, preconceito social, falta de oportunidades no mercado de trabalho, ou seja, a mesma situação que as tornou vulneráveis ao tráfico, e são assim retraficadas. Segundo Kara ${ }^{426}$, em um abrigo na Albânia ele encontrou uma moça que foi retraficada cinco vezes.

Conclui-se que o legislador brasileiro precisa se preocupar com o "fenômeno do tráfico de pessoas", que engloba todo o processo de escravização de um ser humano: desde o aliciamento até a efetiva exploração. No caso do tráfico internacional de pessoas a cooperação internacional é essencial, pois a exploração ocorrerá no país de destino. É um delito fracionado, e cada conduta ilícita que lesar ou expuser a perigo um bem jurídico penalmente tutelado deverá ser punida.

\footnotetext{
${ }^{425}$ KARA, op. cit., p. 15. "Because the laws in most countries against rape, torture, and homicide are more punishing and better enforced than those against sex trafficking - which can be construe as the aggregation of rape, torture, and homicide - the fate of the world's sex slaves remains terribly grim".

${ }^{426}$ Iden, p. 16.
} 


\section{OS TRÊS P'S: PREVENÇÃO, PUNIÇÃO E PROTEÇÃO}

"To confront the complexity of the global slave trade demands a highly skilled and trained army of abolitionists".

O Protocolo de Palermo é pautado em três eixos: a prevenção, consistente na adoção de medidas com o escopo de reduzir fatores como a pobreza, o subdesenvolvimento e a desigualdade de oportunidades, que tornam as pessoas vulneráveis ao tráfico; a punição efetiva dos traficantes, por meio de criminalização de condutas e cooperação internacional; e, finalmente, a proteção ou atenção às vítimas desse crime, respeitando plenamente seus direitos humanos. Não no mesmo contexto, mas com o mesmo escopo, Esther de Figueiredo Ferraz $^{427}$ afirmava que a luta contra a prostituição incluía a prevenção do meretrício, a repressão do lenocínio e a recuperação da decaída.

No Brasil, o Decreto n. 5.948, de 2006, instituiu a Política Nacional de Enfrentamento ao Tráfico de Pessoas, com a finalidade de estabelecer princípios, diretrizes e ações de prevenção e repressão ao tráfico de pessoas e de atenção às vítimas, além de determinar a elaboração do PNETP. A Política tem como princípios norteadores o respeito à dignidade humana, a não discriminação, a proteção e assistência integral às vítimas diretas e indiretas, a promoção e garantia da cidadania e dos direitos humanos e o respeito a tratados e convenções internacionais de direitos humanos.

O I PNETP foi aprovado pelo Decreto n. 6.347, de 2008, e estabelece ações de curto, médio e longo prazo nos três eixos determinados pelo Protocolo de Palermo e pela Política Nacional (prevenção, punição e proteção).

Neste capítulo far-se-á a análise de alguns depoimentos de vítimas de tráfico de pessoas para fim de exploração sexual, e em meio a essa realidade serão avaliadas as formas atuais de prevenção do crime, a punição dos agentes e a proteção das vítimas.

${ }^{427}$ FERRAZ, op. cit., p. 63. 
Para o pesquisador Siddharth $\mathrm{Kara}^{428}$, alguns fatores demonstram a atual ineficiência no combate ao tráfico. São eles: a) apesar do aumento da atenção da mídia para esse crime, este ainda é pouco compreendido; b) as organizações que se dedicam ao combate ao tráfico para fins sexuais são carentes de recursos e não possuem uma coordenação ou colaboração internacional; c) a legislação contra o tráfico de pessoas é frágil e pouco aplicada; d) embora existam numerosos estudos e artigos sobre o tema, ainda não foi feita uma análise econômica e empresarial da indústria do tráfico a fim de identificar pontos estratégicos para intervenção. Ou seja, ainda há um longo caminho a ser percorrido.

Desta forma, não se pode admitir que, em um Estado Social e Democrático de Direito, a Declaração Universal dos Direitos do Homem, que proíbe a escravidão e o tráfico de escravos ${ }^{429}$, bem como outros acordos que dispõem sobre direitos humanos sejam apenas cartas de intenções.

\subsection{DEPOIMENTOS}

"Mulheres que não se pertencem e que, como animais, são vendidas $e$ revendidas, exploradas e maltratadas, ao ponto de já haverem perdido toda a noção de dignidade humana."

Esther de Figueiredo Ferraz (In: Prostituição e criminalidade feminina, p. 3.)

A cada minuto mulheres e crianças são violentadas e exploradas sexualmente por sujeitos hediondos, sofrendo toda sorte de humilhações, restrições e crueldade. Os depoimentos das vítimas são estarrecedores, assim como é estarrecedora a impunidade que cinge esse crime abjeto.

Nesse tópico serão apresentadas as trajetórias de quatro mulheres. A nacionalidade das vítimas e as fontes da pesquisa são distintas, porém o início da história é sempre o mesmo: uma situação de extrema vulnerabilidade e a busca de uma vida melhor.

\footnotetext{
${ }^{428}$ KARA, Siddharth. Sex trafficking: inside the business of modern slavery, p. 3.

429 “Art. IV - Ninguém será mantido em escravidão ou servidão, a escravidão e o tráfico de escravos serão proibidos em todas as suas formas".
} 


\subsubsection{Maya, 15 anos, nepalesa ${ }^{430}$}

"The malik put chili paste on a broomstick and pushed it inside me. Then he broke my ribs with his fist".

Maya nasceu em Sindhupalchok, Nepal, uma das regiões mais pobres do planeta, com renda per capita anual de 180 dólares. Como seus pais estavam desesperados para suprir as necessidades da família, venderam a menina para um agente local por 55 dólares, com a promessa de que ela teria um bom emprego em uma fábrica de tapetes, podendo assim enviar para casa até 10 dólares por mês.

$\mathrm{Na}$ noite em que Maya deixou sua casa, o agente a revendeu para um dalal (traficante), que a levou para uma cidade na fronteira com a Índia. Lá encontraram mais uma garota. No dia seguinte os três cruzaram a fronteira a pé, e poucos dias depois estavam em Mumbai.

Chegando a Mumbai, o dalal a vendeu para um malik (dono de bordel) em Kamathipura $^{431}$. O malik disse a Maya que ela lhe devia 35 mil rúpias (780 dólares), e que deveria ter relações sexuais com qualquer homem que a escolhesse até pagar essa dívida. Ela se recusou, e foi estuprada por homens do malik e deixada sem comida. Quando finalmente concordou em se submeter às condições do malik, recebeu medicamentos para tratar uma infecção urinária e foi obrigada a fazer sexo com cerca de vinte homens por dia.

Segundo Maya, havia centenas de meninas nesse bordel, muitas do Nepal. Uma vez ela escapou e conseguiu ir à polícia dizer o que estava ocorrendo, mas os policiais não fizeram nada. Poucos dias depois, os homens do malik a encontraram nas ruas e a levaram de volta ao bordel. O malik colocou pasta de pimenta no cabo de uma vassoura e o empurrou para dentro dela. Depois disso, quebrou suas costelas. A gharwali (gerente ou madame) cuidou de suas feridas por um curto período, e após esse tempo Maya foi submetida à exploração sexual novamente, apesar da grande dor que sentia nas costelas. A gharwali lhe dava ópio para diminuir a dor.

\footnotetext{
${ }^{430}$ Maya, aos dezenove anos, concedeu uma entrevista ao pesquisador Siddharth Kara, após quase quatro anos de exploração sexual em regime de escravidão. O depoimento foi reproduzido na obra Sex trafficking: inside the business of modern slavery, p. 2-3. O nome da vítima é fictício. (tradução nossa)

${ }^{431}$ Famoso "distrito da luz vermelha" em Mumbai.
} 
Depois de dois anos, o malik a revendeu para outro malik, de Falkland Road ${ }^{432}$. Nesse bordel ela vivia em uma pinjara (gaiola), com outra mulher. O local era muito pequeno e barulhento, já que ficava na rua. Maya ficou grávida por duas vezes nesse período, e a gharwali lhe deu comprimidos para abortar. Da segunda vez ela ficou muito doente. Quando se recuperou, conseguiu fugir. Foi para um abrigo próximo ao bordel, onde ficou sabendo que era portadora do vírus HIV. Recebeu ajuda para contatar seu pai, mas este disse a ela que não voltasse para casa, pois nunca poderia se casar, e por ser portadora do HIV traria apenas vergonha para a família.

\subsubsection{Simone, 25 anos, brasileira ${ }^{433}$}

"Olha o que fizeram comigo, pai." (In: PESTRAF, p. 120.)

Simone morava na periferia de Goiânia com os pais, uma irmã e o filho de quatro anos. Todos eram sustentados pelo pai, que ganhava pouco mais que um salário mínimo. Em janeiro de 1996 Simone embarcou para a Espanha com o objetivo de juntar muito dinheiro para oferecer melhores condições de vida a seus familiares ${ }^{434}$.

Ela foi aliciada por duas irmãs: uma delas era sua vizinha e a outra exercia a prostituição na Espanha. Segundo as irmãs, desde o início Simone sabia que viajaria para

432 Outro importante "distrito da luz vermelha" em Mumbai.

${ }^{433}$ A história de Simone Borges Felipe está disponível na Pesquisa sobre o tráfico de mulheres, crianças e adolescentes para fins de exploração sexual comercial - PESTRAF, organizada por Maria Lúcia Leal e Maria de Fátima Leal, p. 118-125. No ano 2011 o Ministério da Justiça promoveu a $1^{a}$ edição do Prêmio Abraçando o Enfrentamento ao Tráfico de Pessoas: Simone Borges Felipe. O prêmio é uma homenagem à luta do pai de Simone, João Borges, em informar outras pessoas sobre as falsas promessas de aliciadores. O concurso visa fomentar a divulgação de boas práticas e é voltado para candidatos do serviço público e organizações da sociedade civil que trabalham diretamente no enfrentamento ao tráfico de pessoas, na perspectiva da prevenção e da repressão, responsabilização dos autores e atenção às vítimas.

${ }^{434}$ Pérez Alonso afirma que na Espanha há um tipo "padrão" de tráfico de mulheres para prostituição, que é praticamente o retratado neste caso. Segundo o autor, elas são recrutadas por organizações mais ou menos complexas, que mantêm contato com aliciadores nos países de origem. As mulheres costumam ser de classe social baixa, com grandes necessidades econômicas, dispostas a emigrar em busca de melhores condições de vida. As ofertas são tentadoras, em trabalhos como o doméstico ou em hotelaria. A própria organização se ocupa da documentação e passagens. Chegando ao destino são requisitados o passaporte, o dinheiro emprestado para entrar como turista no País e a passagem de volta. A partir daí são obrigadas a se prostituir para pagar a dívida com a organização, em regime de escravidão ou servidão, submetidas a toda sorte de violência. In: PÉREZ ALONSO, Esteban J. Consideraciones político-criminales sobre el fenómeno migratorio actual y el tráfico de personas. In: MIR PUIG, Santiago; CORCOY BIDASOLO, Mirentxu (dir.). Protección penal de los derechos de los trabajadores: seguridad en el trabajo, tráfico ilegal de personas e inmigración clandestina, p. 428. 
se prostituir. Para a família da vítima, a proposta era viajar para trabalhar como garçonete. A versão da família é corroborada por outra vítima, que também foi aliciada pelas irmãs. Ela conta que foi convidada para trabalhar como garçonete ou babá, mas que, chegando à Espanha, percebeu que teria de exercer a prostituição e conseguiu fugir no mesmo dia. Essa outra vítima foi levada para a mesma boate onde Simone trabalhava - Cesar Palace. Ela afirma que todas as meninas estavam drogadas, bebiam muito e circulavam entre as mesas nuas ou seminuas.

Após um mês de sua chegada à Espanha, Simone telefonou para os pais chorando muito e pedindo para a família entrar em contato com o consulado para tirá-la daquele inferno.

Em abril a família foi avisada de que ela havia morrido, e contestou o atestado de óbito, que apontava insuficiência-respiratória aguda, infecção pulmonar e tuberculose. No Brasil foi feita uma autópsia que descartou a morte por tuberculose e indicou como causa mortis presumível insuficiência renal e hepática aguda, que poderia ter sido causada tanto por uma overdose como por um choque anafilático causado por algum medicamento ministrado à vítima. Posteriormente, o Instituto Nacional de Toxicologia da Espanha descartou de vez a possibilidade de tuberculose, e o hospital que a atendeu admitiu o erro no diagnóstico.

Segundo relatos de colegas de Simone na Espanha, elas viviam em um pequeno apartamento sem calefação. Mesmo doente, Simone foi obrigada a trabalhar até dois dias antes de sua morte, sob ameaças do dono do bordel. Chegando ao hospital, foi tratada com muita indiferença pelos funcionários.

\subsubsection{Nadia, 22 anos, moldávia ${ }^{435}$}

"No way! You have the wrong idea about us! We will work very hard for you in a restaurant, but we cannot do this kind of work."

\footnotetext{
${ }^{435}$ A história de Nadia é relatada por David Batstone na obra Not for sale, p. 140-181 (tradução nossa).
} 
Nadia era mais uma jovem pobre, mãe solteira, da Moldávia ${ }^{436}$, pequeno país que fazia parte do antigo bloco da União Soviética. Ela decidiu aceitar o convite de uma excolega de classe, Katrina, para trabalhar em um restaurante na Itália quando foi inscrever O filho de seis anos na escola e não tinha dinheiro para pagar as despesas com matrícula e uniforme. Sua família não poderia ajudá-la, já que tudo o que ganhavam dava somente para a comida.

Em oito dias ela já estava preparada para viajar. Quando chegou ao local combinado havia mais seis garotas aguardando, todas aliciadas por Katrina e aparentando menos de 18 anos. Foi-lhe pedido que entregasse seu passaporte, pois o guia da viagem o guardaria em segurança. Quando Katrina entregou o passaporte ao guia, Nadia percebeu que a aliciadora recebeu um maço de dinheiro.

Embarcaram em três carros e iniciaram a viagem. Na fronteira com a Romênia, trocaram de carro e a aliciadora as deixou. Cruzaram a fronteira e chegaram a uma casa onde já havia três garotas romenas. Foram trancadas nessa casa, sem nenhum esclarecimento sobre onde estavam e para onde iriam. A única explicação do guia é que estavam tentando conseguir os vistos para entrar na Itália. Sete dias depois os traficantes afirmaram ter os vistos e embarcaram em duas vans rumo à Sérvia. Chegando à fronteira daquele país, afirmaram que tinham apenas os vistos para a Itália, e que deveriam ingressar ilegalmente na Sérvia. Escolheram um local deserto, e, na escuridão da noite, as meninas foram obrigadas a correr rumo à Sérvia, em um terreno muito acidentado. Com alguns cortes nas pernas, todas conseguiram cruzar a fronteira, onde três carros as aguardavam.

Foram levadas para uma casa em um local deserto, onde encontraram mais uma dúzia de meninas traficadas, sentadas no chão, com a aparência exausta, machucadas e sujas de sangue. Nessa casa Nadia dividiu o quarto com meninas da Romênia, Ucrânia e Bulgária, todas com promessas de trabalho na Itália. Alguns dias depois a mulher responsável pela casa, uma russa, entrou no quarto e pediu que todas as meninas descessem até a sala, onde havia um grupo de homens para avaliá-las. A orientação era a de que, assim que entrassem na sala, tirassem a blusa e mostrassem os seios. Nadia protestou e a resposta foi que esse procedimento era praxe entre os empregadores italianos, que

\footnotetext{
${ }^{436}$ Também denominado Maldávia ou Moldova.
} 
precisavam ter certeza de que elas estavam saudáveis. Na sala havia pouco mais de dez de homens, que as analisaram como se fossem mercadorias.

Poucas horas depois Nadia e uma romena foram chamadas para partir. Um homem falando um russo vacilante levou as duas para um apartamento em um bairro residencial de Belgrado. Lá as duas foram avisadas de que deveriam se prostituir. Nadia novamente protestou, e o homem que a comprou a ameaçou com uma faca. Cada uma delas foi levada a um quarto e todas foram estupradas por clientes. Nos meses seguintes, essa prática ocorreu reiteradamente.

Um dia a russa que cuidava da antiga casa apareceu no apartamento onde as duas estavam e as levou com a promessa de que logo estariam trabalhando em um café em Roma. Dois dias depois, Nadia, a romena e mais três ucranianas foram conduzidas por dois russos até Montenegro, onde ficaram hospedadas por alguns dias em uma casa. De lá foram levadas de barco até a Albânia. No meio do caminho o piloto parou o barco e escolheu Nadia para ser estuprada, sob a ameaça de que todas as meninas seriam jogadas da embarcação caso ela não colaborasse. Chegando à fronteira, foram abordadas pela polícia albanesa, que, ao invés de ajudá-las, levou-as para um bordel em Shkodër. Antes disso, cada policial escolheu uma garota e a estuprou.

Nadia ficou por um mês no bordel em Shkodër, Albânia, e atendia cerca de 25 homens por dia. Aos 22 anos, foi considerada muito velha e vendida para um bordel em Roma.

Foi transportada novamente em um barco, agora bem maior, com cerca de 40 pessoas, até bem próximo à costa da Itália, onde foram obrigadas a pular e a seguir nadando ou flutuando. Eram todos imigrantes ilegais tentando chegar ao ocidente. Nadia carregava um cartão que dizia: "Quando chegar à praia próximo a San Foca, seu novo dono a estará esperando". Recebeu a recomendação de que, caso se perdesse, deveria ligar para um determinado número de telefone e seria levada a Roma. Se tentasse escapar, seria caçada e morta.

Chegando a San Foca, Nadia resolveu que não se entregaria voluntariamente àquele inferno. Resolveu procurar algo para comer. Uma funcionária da padaria logo percebeu do 
que se tratava e entrou em contato com o Padre Cesare, que cuida do abrigo para vítimas de tráfico de pessoas Regina Pacis, naquela cidade.

Hoje Nadia está casada e levou seu filho para morar com ela na Itália.

\subsubsection{Rath, 15 anos, cambojana ${ }^{437}$}

"Pensamos que, mesmo que morrêssemos, seria melhor do que ficar ali. Se ficássemos, também iríamos morrer."

Quando Rath tinha 15 anos, sua família ficou sem dinheiro e ela decidiu trabalhar como lavadora de pratos na Tailândia por dois meses, para ajudar a pagar as contas. Ela e mais quatro amigas foram levadas por um agente de trabalho ao interior da Tailândia. Lá foram entregues a traficantes que as levaram para Kuala Lumpur, capital da Malásia, onde foram compradas pelo dono de um caraoquê, que na verdade era um bordel. Ele explicou para as meninas que já havia gasto muito dinheiro com elas, e que precisavam pagar tal dívida antes de serem libertadas.

Rath foi trancada em um quarto com um cliente. Quando se deu conta do que estava acontecendo, reagiu e ele foi embora furioso. Como punição, ela foi espancada e estuprada pelo dono do bordel e seus capangas.

Eles diziam que ela precisava colaborar e servir os clientes ou seria espancada até a morte. Como ela não cedia, era drogada para ficar mais dócil. O comprimido era chamado de "a droga feliz".

As moças eram obrigadas a trabalhar quinze horas por dia, e eram mantidas nuas para não poderem esconder dinheiro e tentar uma eventual fuga. Eram proibidas de pedir aos clientes que usassem preservativos. Não podiam sair e não recebiam pelo trabalho. Se

${ }^{437}$ Srey Rath concedeu uma entrevista aos jornalistas Nicholas Kristof e Sheryl Wudunn, reproduzida na obra Metade do céu: transformando a opressão em oportunidades para as mulheres do mundo todo, p. 15-22. 
não estivessem sempre sorrindo, eram reiteradamente espancadas. Recebiam pouca comida, pois as mulheres acima do peso não eram apreciadas.

Eram transportadas sob guarda entre o bordel e um apartamento onde moravam doze delas. A porta era fechada por fora. Certa noite, as garotas pegaram um suporte que usavam para estender roupa, de 4 metros de cumprimento por 12 centímetros de largura, e a equilibraram entre a varanda do apartamento, no $10^{\circ}$ andar, e o prédio vizinho. A tábua oscilava muito, mas Rath preferiu arriscar-se a continuar naquela situação, que de qualquer forma a levaria à morte. Ela e mais três meninas conseguiram atravessar, e bateram na porta do outro apartamento até acordarem o morador. Mal conseguiram se comunicar, pois elas não falavam malaio, mas ele as deixou sair.

Vagaram pelas ruas até chegar a uma delegacia. Primeiro os policiais tentaram enxotá-las, mas depois as prenderam por imigração ilegal. Rath ficou presa por um ano, até poder ser repatriada.

Em vez de ser levada para casa, Rath foi conduzida por um policial malaio até a fronteira da Tailândia e vendida a um traficante, que a levou para um bordel tailandês.

Os proprietários do bordel tailandês não a espancavam nem a vigiavam constantemente. Assim, dois meses depois ela conseguiu fugir e retornou para o Camboja.

Em seu país, uma assistente social a colocou em contato com um grupo que auxiliava vítimas do tráfico a recomeçar a vida. O grupo American Assistance for Cambodia usou 400 dólares de fundos doados para comprar uma pequena carroça e algumas mercadorias para Rath se tornar uma vendedora ambulante. Ela encontrou um bom lugar, trabalhou muito, economizou e conseguiu transformar sua carroça em duas barracas. Hoje está casada, tem um filho e já começou a economizar para a educação dele. Além disso, pode ajudar os pais e as duas irmãs mais novas. 


\subsection{PREVENIR, PUNIR E PROTEGER: A NECESSIDADE DO TRABALHO EM REDE}

Como se observa dos depoimentos acima, os esforços para combater o tráfico de pessoas ainda são incipientes, seja no Brasil ou no exterior. A corrupção, o despreparo da polícia, de agentes de fronteira ou de saúde, o descaso dos governos, a pobreza, a falta de oportunidades no país de origem, são fatores que contribuem com o crescimento desse crime.

Para David Batstone ${ }^{438}$, todos podem contribuir de alguma forma para acabar com a mercancia de escravos. Advogados e promotores são necessários para proteger os direitos das vítimas e processar os criminosos; empresários precisam acabar com o trabalho escravo em suas empresas e não negociar com grupos que adotem essa prática; estudantes precisam desenvolver pesquisas sérias que influenciem políticas públicas; e profissionais da área da saúde são necessários para restabelecer a saúde física e psicológica das vítimas.

Para Eliana Vendramini ${ }^{439}$, apenas o trabalho em rede r40/441 $^{\text {permitirá } o}$ enfrentamento de modo promissor. Essa rede deve congregar os atores da política pública, judiciária, de direitos humanos e a sociedade civil organizada. São inúmeros os problemas ainda enfrentados, como a falta de varas especializadas, de dados estatísticos padronizados e da adequação da legislação pátria ao Protocolo de Palermo.

Far-se-á nesse tópico uma breve explanação das ações de enfrentamento ao tráfico adotadas no Brasil (PNETP), e da relevância da prevenção a esse fenômeno junto às

${ }^{438}$ BATSTONE, David. Not for sale, p. 259-260.

${ }^{439}$ CARNEIRO, Eliana Faleiros Vendramini. O monitoramento das políticas públicas no enfrentamento ao tráfico de pessoas (no prelo).

${ }^{440}$ Nesse sentido, Elena Florencia Onassis: "Involucrarse en el trabajo conjunto de las instituciones del Estado y las organizaciones civiles es la única herramienta con que contamos para combatir la Trata de Personas". In: Trata de personas: la esclavitud del siglo XXI, p. 164.

${ }^{441}$ Um exemplo de sucesso nesta seara é o Núcleo de Enfrentamento ao Tráfico de Pessoas do Estado de São Paulo - NETP. Os Núcleos foram criados pela Secretaria Nacional de Justiça (Ministério da Justiça), em parceria com os governos estaduais, tendo por principal função articular e planejar as ações de enfrentamento ao tráfico no âmbito estadual. Existem Núcleos nos seguintes estados: Bahia, São Paulo, Goiás, Rio de Janeiro, Ceará, Pernambuco, Pará e Acre. Tendo como princípio o trabalho em rede, o NETP-SP é o resultado de uma parceria entre governo e sociedade civil, envolvendo o Governo do Estado de São Paulo, o Governo Federal, o Consulado dos Estados Unidos da América, a ONG Serviço da Mulher MarginalizadaSMM, e outras dezenas de associações civis. Com o mérito da credibilidade das ações desenvolvidas, o aumento da demanda de casos para atendimento vem sendo um grande desafio a ser superado atualmente. $\mathrm{O}$ órgão realiza plantões com vistas a oferecer suporte às blitz realizadas pelas polícias (Civil, Federal e Interpol), além de prestar assistência integral às vítimas. 
possíveis vítimas, da repressão ao crime e consequente punição dos traficantes e a proteção e atenção às vítimas que já foram traficadas.

O PNETP ${ }^{442}$, instituído em 2008, deveria ser executado em dois anos. Foi elaborado por um grupo de trabalho interministerial, integrado por representantes de órgãos públicos federais, do Ministério Público, Poder Judiciário, Poder Legislativo, estados, municípios, Distrito Federal, universidades e a sociedade civil organizada, incluindo ONGs e organismos internacionais representativos dos recortes temáticos de gênero, infanto-juvenil e de combate ao trabalho escravo. $\mathrm{O}$ trabalho foi dividido em três eixos: prevenção ao tráfico de pessoas; repressão ao tráfico e responsabilização de seus atores; e atenção às vítimas.

Nos termos do Relatório Final de Execução do Plano Nacional de Enfrentamento ao Tráfico de Pessoas, o PNETP teve como principal objetivo integrar os diversos órgãos governamentais, sociedade civil e organismos internacionais para a implementação de ações, no Brasil, contribuindo para a redução do tráfico de pessoas. Porém, não conseguiu executar todas as ações previstas no prazo estipulado de 2 anos. O II PNETP está em fase de elaboração.

A prevenção ao tráfico de pessoas se apresenta como o meio mais eficaz para o seu enfrentamento. Segundo o PNETP, nesse âmbito a intenção é diminuir a vulnerabilidade de determinados grupos sociais ao tráfico e fomentar o seu empoderamento, bem como engendrar políticas públicas voltadas para combater as reais causas estruturais do problema. As prioridades estabelecidas pelo PNETP são as seguintes: a) levantar, sistematizar, elaborar e divulgar estudos, pesquisas, informações e experiências sobre o tráfico de pessoas; $b$ ) capacitar e formar atores envolvidos direta ou indiretamente com o enfrentamento ao tráfico na perspectiva dos direitos humanos; $c$ ) mobilizar e sensibilizar grupos específicos e a comunidade em geral sobre o tema; $d$ ) diminuir a vulnerabilidade ao tráfico de pessoas de grupos sociais específicos.

No tocante à punição o foco do PNETP se reflete em ações de fiscalização, controle e investigação, considerando os aspectos penais e trabalhistas, nacionais e

\footnotetext{
${ }^{442}$ Relatório Final de Execução do Plano Nacional de Enfrentamento ao Tráfico de Pessoas, p. 57.
} 
internacionais desse crime. As prioridades do Plano são as seguintes: a) aperfeiçoar a legislação brasileira relativa ao enfrentamento ao tráfico de pessoas e crimes correlatos; $b$ ) ampliar e aprofundar o conhecimento sobre o tema nas instâncias e órgãos envolvidos na repressão ao crime e responsabilização dos autores; c) fomentar a cooperação entre os órgãos federais, estaduais e municipais envolvidos no enfrentamento ao tráfico de pessoas para atuação articulada em sua repressão e na responsabilização de seus autores; $d$ ) criar e aprimorar instrumentos para o enfrentamento ao tráfico de pessoas; $e$ ) estruturar órgãos responsáveis pela repressão ao crime e responsabilização de seus autores; $f$ ) fomentar a cooperação internacional para repressão ao delito.

No tocante às ações voltadas à repressão do crime e à punição dos traficantes, infelizmente não se vê um avanço, especialmente no aspecto legislativo, que foi objeto de análise nesse trabalho. Conforme expõe Renato Silveira, o sistema deve amoldar-se à realidade fática ${ }^{443}$. O direito precisa pautar-se tanto na política criminal quanto na dogmática penal. Ambos devem influenciar a criminalização primária (elaboração das leis) e secundária (âmbito judicial e executório). E isso ainda não foi feito.

Com relação à proteção das vítimas do tráfico, o PNETP visa o seu tratamento justo, seguro e não discriminatório, além de sua reinserção social, adequada assistência consular, proteção especial e acesso à justiça. O conceito de vítima inclui brasileiros e também estrangeiros traficados para o Brasil. É prioridade do Plano: articular, estruturar e consolidar, a partir dos serviços e redes existentes, um sistema nacional de referência e atendimento às vítimas de tráfico.

Muitas das ações propostas pelo PNETP são importantes tanto para a prevenção, como para a punição e a proteção, e, por essa razão, discorrer-se-á sobre elas de forma conjunta. Segundo Lucilla Viana ${ }^{444}$, a prevenção deve ser vista em três momentos distintos: prevenção primária, que é aquela que se dá antes da ocorrência do crime. São ações de promoção e prevenção sobre fatores predisponentes, ou seja, que interrompem a cadeia de eventos antes de sua ocorrência, como, por exemplo, campanhas educativas e oficinas informativas para públicos diferenciados. A seguir vem a prevenção secundária,

\footnotetext{
${ }^{443}$ SILVEIRA, Renato de Melo Jorge. Crimes sexuais, p. 31-32.

444 VIANNA, Lucila. Tráfico de pessoas: o olhar da epidemiologia. In: LANDINI, Tatiana Savoia; OLIVEIRA, Marina P. P. (org.). Enfrentamento ao tráfico de pessoas, p. 56-58.
} 
que ocorre imediatamente após o crime, e otimiza a assistência nas diferentes fases de atendimento às vítimas do tráfico, como na área da saúde, jurídica e psicossocial. Finalmente ocorre a prevenção terciária, que tem como foco minimizar as sequelas por meio de assistência a longo prazo, visando a reabilitação e a reintegração da vítima à sociedade. Desta forma, não importa a denominação e classificação dada às ações - se referente à prevenção, proteção ou punição - e sim a sua implementação de forma eficaz.

Como já foi mencionado, não existem pesquisas completas e confiáveis sobre o tráfico de pessoas. As causas são variadas, como a falta de um conceito único do crime, a confusão com outros fenômenos, como prostituição voluntária ou tráfico de migrantes, a escassez de fontes oficiais, a falta de colaboração de órgãos públicos etc. Independente desses fatores, é fundamental mapear ${ }^{445}$ com precisão a situação do tráfico de pessoas no país, identificando suas causas, alcance, efeitos, bem como suas vítimas. Esse levantamento é imprescindível para os três eixos de enfrentamento ao delito, e precisa do envolvimento de organismos internacionais, instituições públicas, polícia, judiciário, e também da sociedade civil, inclusive das universidades.

A capacitação é outro ponto fulcral no enfrentamento ao tráfico. É fundamental fomentar programas de sensibilização, treinamento e capacitação de todos os agentes que eventualmente ou certamente terão contato com potenciais vítimas, ou pessoas já vitimizadas. Pais, professores e demais funcionários das escolas, polícias, agentes comunitários, igrejas, profissionais da saúde, todos precisam estar envolvidos e de ouvidos atentos a esse perigo.

Quando a vítima de tráfico é encontrada pela polícia ou é levada a um hospital, por exemplo, ela terá uma maior dificuldade para falar se não for criado um ambiente de confiança e acolhimento. Comportamentos como falta de cooperação, hostilidade, incapacidade de lembrar eventos com detalhes, mudança de versões, enganos etc., são resultantes dos traumas vivenciados. E, enquanto não houver uma qualificação adequada dos órgãos do Estado e associações civis, bem como uma clara identificação de que se trata

445 PIOVESAN, Flávia. Tráfico de pessoas para fins de exploração sexual. Disponível em: $<$ http://www.justica.sp.gov.br/Modulo.asp?Modulo=595>. Acesso em: 15 dez. 2011. A autora enumera sete desafios para o combate ao tráfico de pessoas para fins de exploração sexual, que serão estudados ao longo desse capítulo. 
de uma vítima de tráfico, e não um criminoso, não existirá um enfrentamento adequado ao tráfico de pessoas, além de revitimizar quem deveria ser protegido.

Os profissionais da saúde, como os que trabalham em pronto-socorros, precisam receber treinamento adequado para identificar uma possível vítima de exploração sexual. Caso contrário, por não saberem com quem estão lidando, podem "devolver" a vítima ao cativeiro. Elena Florencia Onassis ${ }^{446}$ enumera alguns indícios que ajudam a distinguir uma vítima de tráfico que chega ao hospital: pessoa sob controle ou vigilância de alguém; hematomas e outros sinais de violência; desconhecimento do idioma local; não apresentação de passaporte ou outro documento de identificação; dores pélvicas; malnutrição etc.

Outro profissional que necessita ser preparado é o que trabalha com a saúde metal, como o psicólogo, o terapeuta ou o psiquiatra. O tráfico não pode ser tratado como um caso de estupro, violência ou sequestro. É uma situação muito específica. Thereza Flores $^{447}$, que foi escravizada sexualmente, conta que procurou um grupo de ajuda a pessoas que haviam sido estupradas. Mas ela não se enquadrava naquele contexto, porque foi estuprada inúmeras vezes, por pessoas diferentes. Ela "pertencia" a seus exploradores, era comercializada, espancada, vendida. Uma situação muito mais complexa que um estupro, que requer cuidados muitos especiais.

A confiança e identificação com o interlocutor é uma questão muito relevante, que exige atenção especial e capacitação. No livro Meninas da noite, Gilberto Dimenstein ${ }^{448}$ relata que as meninas não conseguiram falar abertamente com ele sobre sua história, preferindo contá-la à fotógrafa que o acompanhava, Paula Simas. A figura masculina é associada à violência e opressão a que elas foram submetidas. Policiais, agentes de fronteiras ou imigração, e outros que tenham um contato inicial com a vítima, precisam ser devidamente capacitados.

Deve haver também a ampliação e o fortalecimento de ações de conscientização pública. Essas ações podem compreender campanhas educativas, distribuição de material

\footnotetext{
${ }^{446}$ FLORENCIA ONASSIS, Elena. Trata de personas: la esclavitud del siglo XXI, p. 176-177.

${ }^{447}$ FLORES, Theresa L. The slave across the street, p. 135-139.

${ }^{448}$ DIMENSTEIN, Gilberto. Meninas da noite, p. 108-109.
} 
informativo junto a passaportes, cartazes em aeroportos, nas superintendências da Polícia Federal e em locais de grande circulação, além da veiculação de programas de rádio e TV, e também nas escolas.

É necessário que haja uma conscientização popular sobre o tráfico. O cidadão comum precisa entender que essas pessoas são vítimas, que tiveram seus direitos humanos subtraídos. Deve-se criar um ambiente fértil para denúncias e cooperação social, livre de preconceitos. Existe prostituição voluntária, mas também existe a prostituição forçada, que é inadmissível. As pessoas que migram em busca de uma vida melhor entenderam que seria melhor correr o risco a continuar na mesma condição. Nem todos viajam movidos apenas pela ambição. A situação de miséria, conflitos bélicos, discriminação, desastres naturais, tornam essas pessoas presas fáceis para os traficantes. A falta de oportunidades no mercado de trabalho ${ }^{449}$ é outro meio de tornar as pessoas vulneráveis a esse crime, seja pela necessidade de garantir sua subsistência, seja pela impossibilidade de construir um projeto ocupacional satisfatório $^{450}$.

A redução da situação de vulnerabilidade ${ }^{451}$ das possíveis vítimas é a forma correta de prevenção, e tem uma fórmula simples: criar opções viáveis! Contudo, são políticas de médio e longo prazo, como é o caso da educação, o desenvolvimento da economia e a criação de novos empregos. Isso não impede que no curto prazo sejam realizadas ações específicas com grupos mais vulneráveis. O terceiro setor tem papel fundamental nessa tarefa.

\footnotetext{
${ }^{449}$ Existem projetos que visam o desenvolvimento do mercado de trabalho, como o compromisso assumido entre o governo brasileiro e a OIT para a Agenda Nacional de Trabalho Decente. Disponível em: <http://portal.mte.gov.br/antd/>. Acesso em: 29 dez. 2011. A OIT desenvolve outros projetos, como o Programa Internacional de Ação Especial contra o Trabalho Forçado (SAP/FL), o Programa Internacional para a Eliminação do Trabalho Infantil (IPEC), e especialmente o Projeto de Combate ao Tráfico de Pessoas (TIP), que busca a ampliação da base de conhecimento sobre o tema, o fortalecimento institucional de operadores de Direito no País e da conscientização da sociedade sobre o tráfico. O Projeto de Combate ao Tráfico da OIT participou ativamente na elaboração do PNETP (Decreto n. 6.347/2008) e da Política Nacional de Enfrentamento ao Tráfico de Pessoas (Decreto n. 5.948/2006). In: PENNA, Rodrigo; FARIA, Thaís Dumêt. A OIT e sua atuação contra o Tráfico de Pessoas. In: LANDINI, Tatiana Savoia; OLIVEIRA, Marina P. P. (org.). Enfrentamento ao tráfico de pessoas, p. 11-12.

${ }^{450}$ PENNA, Rodrigo; FARIA, Thaís Dumêt. A OIT e sua atuação contra o Tráfico de Pessoas. In: LANDINI, Tatiana Savoia; OLIVEIRA, Marina P. P. (org.). Enfrentamento ao tráfico de pessoas, p. 10.

${ }^{451} \mathrm{Na}$ obra Not for sale, p. 138-174, David Batstone conta a história do padre Cesare Lodeserto que atua na prevenção e proteção das vítimas de tráfico na Rota dos Balcãs. O padre busca a criação de novos empregos para retirar adolescentes e mulheres da condição de vulnerabilidade que pode levá-las a ser vítima do tráfico. Além disso, possui um abrigo - Regina Pacis ou Rainha da Paz- em San Foca, Itália, para abrigar refugiadas desse comércio.
} 
No tocante às denúncias, deve haver um fortalecimento dos serviços e uma maior divulgação. O Disque-denúncia coordenado pelos estados - n. 181 - pode ser utilizado, bem como o Disque 100 - disque-denúncia nacional, coordenado pela Secretaria dos Direitos Humanos, e, também o Ligue 180, sob a responsabilidade da Secretaria de Políticas para as Mulheres ${ }^{452}$, que atende mulheres em situação de violência no País, e, desde novembro de 2011, passou a ter um braço internacional. Existem outros serviços especializados, como o da Divisão de Direitos Humanos da Polícia Federal e do Núcleo de Enfrentamento ao Tráfico de Pessoas - SP, que possuem inclusive número específico para plantão 24 horas. Em Brasília, a Secretaria Especial de Direitos Humanos recebe denúncias do exterior a cobrar ${ }^{453}$.

A proteção das vítimas, mais difundida no Protocolo de Palermo que no PNETP, é de extrema importância. Essa atenção às vítimas envolve vários aspectos, pois esta deve ser acolhida em um ambiente que lhe inspire confiança e onde seus direitos fundamentais sejam assegurados. Um ponto que merece destaque é que essa proteção aos direitos fundamentais das vítimas não deve acarretar efeitos negativos (ou collateral damage). Adriana Piscitelli ${ }^{454}$ levanta alguns desses efeitos, como a internação forçada de prostitutas estrangeiras em abrigos, mesmo que não tenham sido traficadas. Outras vítimas, confundidas com migrantes ilegais, são simplesmente deportadas.

Para que se evitem esses efeitos negativos, a vítima precisa ser atendida por equipes multidisciplinares treinadas, ser acolhida e abrigada ${ }^{455}$, receber suporte psicossocial, jurídico, de saúde etc., ter a opção de retornar ao local de origem ${ }^{456}$ ou permanecer no país ${ }^{457}$, ser assegurado o contato com familiares, dentre outras ações.

\footnotetext{
${ }^{452}$ O serviço para ligações internacionais só está disponível na Espanha, Portugal e Itália. Para ligar do exterior para o Brasil, a mulher precisa entrar em contato com o serviço de telefonista do País onde estiver e pedir a ligação para (61) $3799 \quad 0180 . \quad$ Disponível <http://www.dpf.gov.br/agencia/noticias/2011/novembro/criado-servico-de-atendimento-a-mulheresbrasileiras-residentes-no-exterior>. Acesso em: 15 jan. 2012.

453 Sobre esses serviços veja: <http://www.portalconsular.mre.gov.br/destaques/disque-denuncia-trafico-depessoas-1>, e <http://www.justica.sp.gov.br/Modulo.asp?Modulo=591>. Acesso em: 3 jan. 2012.

454 PISCITELLI, Adriana. Entre as "máfias" e a "ajuda": a construção de conhecimento sobre tráfico de pessoas. Cadernos Pagu, p. 31-32.

${ }_{455}$ Conforme art. $6^{\circ}$ do Protocolo de Palermo.

${ }^{456}$ Conforme art. $8^{\circ}$ do Protocolo de Palermo.

${ }^{457}$ Conforme art. $7^{\circ}$ do Protocolo de Palermo.
} 
Além disso, é necessário que seja prevista uma nova oportunidade de vida para essa vítima, com suporte e acompanhamento eficiente, ou ela poderá ser retraficada. Observa-se que nesse ponto se regressa às ações de prevenção.

A afirmação do jornalista Nicholas Kristof ${ }^{458}$ é dura, mas reflete a realidade: "Resgatar as moças dos bordéis é a parte fácil. O desafio é impedi-las de retornar". Kristof teve a experiência de - em pleno século XXI - comprar duas escravas sexuais no Camboja $^{459}$. Seu grande desafio foi mantê-las longe dos bordéis. O estigma que enfrentam em suas comunidades, a dependência de drogas, as ameaças dos cafetões, a falta de oportunidades, são motivos que normalmente as levam de volta aos bordéis.

Alguns exemplos são vitoriosos, como o que envolve a indiana Sunitha Krishnan, da organização Prajwala (Chama Eterna) ${ }^{460}$. Seu trabalho consiste em fornecer reabilitação, aconselhamento e trabalho às vítimas de tráfico e prostitutas. A reabilitação consiste em prepará-las para ganhar seu próprio dinheiro, com treinamentos que duram de seis a oito meses. Os cursos abrangem trabalhos com artesanato, encadernação de livros, solda e marcenaria. Segundo Sunitha, $85 \%$ das mulheres treinadas conseguem se afastar da prostituição $^{461}$.

As vítimas do tráfico de pessoas apresentam traumas físicos e psicológicos que pode as acompanhar pelo resto da vida. Quando são resgatadas ou conseguem fugir apresentam sintomas como apatia, perda de memória, mudança brusca de humor, hostilidade, comportamento autodestrutivo, dor de cabeça, fadiga, insônia, náusea, dor generalizada pelo corpo, além de doenças sexualmente transmissíveis, incluindo a AIDS. Segundo a psicóloga Adriana Tucci ${ }^{462}$, entre os transtornos psicopatológicos mais frequentes observados nas vítimas de tráfico de pessoas estão a ansiedade e a depressão. Afirma que dos transtornos de ansiedade, um dos mais comuns para a vítima de tráfico é o transtorno do estresse pós-traumático.

\footnotetext{
${ }^{458}$ KRISTOF e WUDUNN, op. cit., p. 61.

${ }^{459}$ Srey Neth, aparentava 14 ou 15 anos (não sabia a sua idade) e estava no bordel há um mês. Foi vendida ao jornalista por US\$ 150,00. Srey Momm era escravizada há cinco anos, e foi vendida por US\$203,00. Os donos dos dois bordéis deram um recibo ao jornalista pela transação. (In: Metade do céu, p. 61-71).

$460<$ http://www.prajwalaindia.com/>.

${ }^{461}$ KRISTOF e WUDUNN, op. cit., p. 85-86.

462 TUCCI, Adriana. Trauma e estresse nas situações das vítimas de tráfico de seres humanos. In: LANDINI, Tatiana Savoia; OLIVEIRA, Marina P. P. (org.). Enfrentamento ao tráfico de pessoas, p. 63-64.
} 
Outro problema é que muitas vezes as vítimas - voluntaria ou involuntariamente não se reconhecem como tal. Elas têm medo de represálias para si ou seus familiares; outras vezes a situação de exploração durou tanto tempo que construíram uma relação de dependência psicológica com seus exploradores; e, finalmente entendem que elas que agiram errado, seja por migrar ilegalmente ou exercer a prostituição.

Como se vê, o tráfico tangencia diversos outros assuntos, como a prostituição, a migração, o trabalho, o turismo sexual, a saúde, a justiça etc. Se não houver um trabalho em rede entre as diversas áreas para a execução das ações previstas no I PNETP, será inevitável que tais ações sejam desenvolvidas de forma truncada, incompleta e desarticulada das demais. O II PNETP precisa identificar e incorporar as best practices desenvolvidas até o momento e superar as falhas e omissões ocorridas.

Em linhas gerais esses são os principais problemas e desafios ao efetivo enfrentamento ao tráfico de pessoas. São ações urgentes, às quais o Estado não pode se eximir. E, elas só terão sucesso se houver uma dura reprimenda à corrupção, que é um ponto visceral. As instituições públicas precisam funcionar de forma ética e eficaz, seja em postos de fronteiras, na confecção de passaportes, na concessão de vistos, nos aeroportos, nas polícias, no judiciário, nos hospitais etc. É importante que a comunidade e especialmente a vítima sintam confiança nas instituições estatais e também nas associações civis. 


\title{
7. A QUESTÃO DO CONSENTIMENTO
}

\begin{abstract}
"That the only purpose for which power can be rightfully exercised over any member of a civilized community, against his will, is to prevent harm to others. His own good, either physical or moral, is not a sufficient warrant. He cannot rightfully be compelled to do or forbear because it will be better for him to do so, because it will make him happier, because, in the opinions of others, to do so would be wise, or even right. [...] Over himself, over his own body and mind, the individual is sovereign." 463
\end{abstract}

John Stuart Mill

(In: On liberty, chapter I)

Nesse último capítulo, será investigado por que o legislador brasileiro ignora o consentimento da pessoa maior e capaz que resolve prostituir-se no exterior contando com o auxílio de outrem. A razão estaria no fato de o consentimento não ser válido na seara penal, de o Estado brasileiro ser paternalista, de o País ainda não ter superado o ranço moralista na escolha do bem jurídico ou de todas as vítimas de tráfico serem vulneráveis e precisarem dessa proteção?

O argumento principal para a adoção dessa postura é que a análise do consentimento pelos tribunais poderia gerar impunidade, pois no caso de realmente existir o crime a discussão se concentraria na conduta da vítima, sob o argumento de que viajou sabendo que exerceria a prostituição, ou que já a exercia no Brasil ${ }^{464}$. Além disso, há uma relação desigual de poder entre as vítimas e os traficantes, o que levaria a uma revitimização ao longo do processo ${ }^{465}$. Os manuais de direito penal, em sua maioria, só afirmam que o consentimento é irrelevante para o tipo penal. Contudo, outros doutrinadores, como Renato Silveira e Tadeu Dix, alertam para a relevância de se enfrentar a questão.

Uma grande diferença entre a legislação brasileira, o Protocolo de Palermo e a legislação de alguns países sobre o tráfico de pessoas para fim sexual refere-se justamente

\footnotetext{
463 "O único propósito para o qual o Poder pode ser legitimamente exercido sobre algum membro de uma comunidade civilizada, contra sua vontade, é para evitar dano a outrem. Seu próprio bem, seja físico ou moral, não é uma garantia suficiente. Ele não pode ser legitimamente compelido a fazer ou deixar de fazer algo porque será melhor para ele, porque vai fazê-lo mais feliz, porque, na opinião dos outros, seria sábio ou mesmo direito. [...] Sobre si mesmo, sobre seu próprio corpo e mente, o indivíduo é soberano". (tradução nossa)

${ }^{464}$ RIBEIRO, Anália Belisa. O enfrentamento ao tráfico de pessoas no Brasil. In: MARZAGÃO JÚNIOR, Laerte (coord.). Tráfico de pessoas. p. 73.

${ }^{465}$ NIREMPERGER, Zunilda; RONDAN; Francisco. Mercaderes de vida: una visión histórica, sociológica y jurídica del delito de trata de personas, p. 110.
} 
ao consentimento válido, entendido como aquele em que está presente a capacidade de discernimento e a liberdade para agir autonomamente de acordo com a vontade.

O Protocolo dispõe expressamente sobre o consentimento. Contudo, apesar da aparente harmonia, a questão do consentimento relativo à prostituição quase inviabilizou o próprio Protocolo. O grupo abolicionista considera o consentimento irrelevante, pois não veem na prostituição uma opção, e sim uma forma de exploração. Já o grupo que defende a regulamentação da prostituição entende que o consentimento deve ser levado em conta, pois trata-se de um trabalho como outro qualquer.

Nos termos do Protocolo de Palermo, quando se tratar de menor de 18 anos o consentimento será irrelevante para a configuração do tráfico, ponto em que ambos os grupos estão de acordo. Porém, quando o indivíduo for maior e capaz o consentimento exclui o crime (vitória do grupo que defende a regulamentação da prostituição). Esse consentimento deverá ser válido, não eivado de qualquer vício, nem obtido mediante ameaça, violência, rapto, fraude, engano, abuso de autoridade ou de situação de vulnerabilidade (vitória do grupo abolicionista, já que esses elementos são muito elásticos, e podem inviabilizar o consentimento válido).

Segundo Roxin ${ }^{466}$ a finalidade do direito penal é unicamente impedir que alguém seja lesionado contra sua vontade. Assim, o paternalismo ${ }^{467}$ estatal apenas se justificaria no caso de déficits de autonomia da pessoa afetada, ou para a proteção de menores.

Nesse passo, muito pertinente a observação de Maria Lúcia Karam ${ }^{468}$, para quem é preciso ter cuidado com mecanismos que, sob o pretexto de tutelar ou proteger determinados grupos de pessoas, considerados mais frágeis ou vulneráveis, acabam por inferiorizá-los, instrumentalizando a materialização de concepções discriminatórias.

\footnotetext{
${ }^{466}$ ROXIN, Claus. Que comportamentos pode o estado proibir sob ameaça de pena? Sobre a legitimação das proibições penais. In: ROXIN, Claus. Estudos de direito penal, p. 44-45.

${ }_{467}$ Joel Feinberg define como paternalismo legal a "razão boa e relevante (embora não necessariamente decisiva) para apoiar uma proibição criminal que irá prevenir um dano (físico, psicológico ou econômico) ao próprio autor. "It is always a good and relevant (though not necessarily decisive) reason in support of a criminal prohibition that it will prevent harm (physical, psychological, or economic) to the actor himself". FEINBERG, Joel. Harm to Self: The moral limits of the criminal law. v. 3. New York: Oxford University Press, 1986, p. 4.

468 KARAM, Maria Lúcia. Violência de gênero: o paradoxal entusiasmo pelo rigor penal. Boletim IBCCrim, p. 6-7.
} 
A seguir serão apresentados os principais pontos relativos ao consentimento na teoria geral do delito e no caso específico do tráfico de pessoas.

\subsection{O CONSENTIMENTO DA VÍTIMA NA TEORIA GERAL DO DELITO}

\subsubsection{Vítima, vitimologia, vitimodogmática}

Antes de abordar o consentimento, é preciso entender qual é a posição da vítima hoje no direito penal brasileiro.

Alessandra Greco ${ }^{469}$ conceitua vítima como "aquele que sofre as consequências de determinada conduta típica, de modo relevante, que propicia a atuação do Estado para atingir os fins do direito penal, no Estado Democrático de Direito".

Para contextualizar a posição da vítima ao longo da história do direito penal podem-se utilizar as palavras de Ana Sofia Schimidt de Oliveira ${ }^{470}$, que afirma ter esta “vivido uma espécie de 'idade de ouro' na antiguidade, ter sido relegada ao olvido com a modernidade e ter sido, finalmente, redescoberta nos últimos tempos".

$\mathrm{O}$ primeiro período remete aos tempos da vingança privada, quando caberia à própria vítima a resolução do conflito. Com o passar do tempo houve o acúmulo de armas e riquezas nas mãos de uma minoria, ou seja, o acúmulo de poder. A partir do século XII a vítima foi afastada da resolução do conflito. As partes envolvidas diretamente não podiam mais resolver a questão por si, devendo submeter-se ao poder constituído ${ }^{471}$. A vítima passou de protagonista a, no máximo, informante ${ }^{472}$.

\footnotetext{
${ }^{469}$ GRECO, Alessandra Orcesi Pedro. A autocolocação da vítima em risco, p. 19.

${ }^{470}$ OLIVEIRA, Ana Sofia Schimidt de. Vitimologia e mulher. In: REALE JÚNIOR, Miguel; PASCHOAL, Janaína (coord.). Mulher e direito penal, p. 55.

${ }^{471}$ Idem, p. 57.

${ }^{472}$ Idem, p. 59.
} 
Nas últimas décadas, contudo, os temas relacionados à vítima vêm paulatinamente ocupando espaço no meio acadêmico, assim como a criação de organizações visando a sua proteção. É a fase do redescobrimento.

Os primeiros estudos sistematizados sobre a vítima surgiram no final da década de 40, marcada pelos horrores da $2^{\text {a }}$ Guerra Mundial ${ }^{473}$. No Brasil, somente na década de 70 do século passado foi publicada a primeira obra voltada a esses indivíduos. Segundo Ana Sofia Schimidt de Oliveira ${ }^{474}$, a partir da década de 80 , com muita clareza, a criminologia teve seu objeto de estudo ampliado, incluindo as questões atinentes à vítima (vitimologia).

Cabe aqui mencionar a crítica de Alessandra $\mathrm{Greco}^{475}$, que afirma que a vítima ainda não mereceu a devida atenção dos legisladores e doutrinadores brasileiros, pois institutos com o consentimento da vítima, a vitimodogmática e a autocolocação da vítima em risco, ainda não são tratados pelo nosso ordenamento.

Nesse ponto é necessária a distinção entre vitimologia e vitimodogmática, e a determinação de qual delas interessa ao presente estudo.

A vitimodogmática inclui o comportamento da vítima na análise do crime. Visa estabelecer qual foi a contribuição dela para a realização do delito, possibilitando uma atribuição mais justa da culpabilidade ao agente ${ }^{476}$. A vitimologia, braço da criminologia, visa investigar a etiologia da vitimização ${ }^{477}$ e estabelecer os tipos de vítimas ${ }^{478}$. Para Elena Larrauri $^{479}$, a vitimologia abrange o estudo de três objetos: as pesquisas de vitimização, que geram informações sobre as vítimas; a posição da vítima no processo penal, que se detém aos seus direitos; e a atenção assistencial e econômica a elas.

A vitimodogmática ${ }^{480}$ se ocupa de institutos como o consentimento, a concorrência de culpas e a provocação da vítima. Para esse estudo a vítima será analisada no tocante à validade de seu consentimento. Existem situações em que a participação da vítima é

\footnotetext{
${ }^{473}$ A criação da vitimologia é atribuída a Benjamin Mendelsohn e Von Hentig.

${ }^{474}$ OLIVEIRA, op. cit., p. 60-61.

${ }^{475}$ GRECO, op. cit., p. 29.

${ }^{476}$ Idem, p. 48.

${ }^{477}$ OLIVEIRA, op. cit., p. 67.

${ }^{478}$ GRECO, op. cit., p. 47.

${ }^{479}$ In: ESER, Albin et. al. De los delitos y de las victimas, p. 285-286.

${ }^{480}$ GRECO, op. cit., p. 45.
} 
importante para a realização do delito. Seu consentimento pode ser determinante para excluir a responsabilidade penal do agente ${ }^{481}$.

\subsubsection{Consentimento e teoria geral do delito}

O brocardo volenti non fit injuria ${ }^{482}$ é o reconhecimento da capacidade de disposição dada ao titular de um bem jurídico. A máxima de Ulpiano manteve-se em desuso por séculos. Apenas recentemente o consentimento da vítima voltou a ser considerado em determinados crimes ${ }^{483}$.

Porém, a forma, as condições, as limitações, os pressupostos para eximir o autor de um crime diante do consentimento da vítima não é questão pacífica. Polaino-Orts ${ }^{484}$ enumera três correntes sobre o tema. São elas:

a) dualista: essa corrente diferencia acordo e consentimento. Quando há acordo exclui-se a tipicidade, e quando há consentimento aplica-se uma causa de justificação.

Essa corrente é a dominante na Alemanha há cerca de meio século, baseada na tese elaborada por Geerds, em 1953. O acordo (Einverständnis) jurídico-penal válido exclui o tipo, pois o agir do agente em acordo ou desacordo com a vontade do sujeito passivo integra a descrição do tipo. Assim, a concordância do titular do bem jurídico determina a ausência de um elemento essencial do tipo. O exemplo clássico é a invasão de domicílio (art. 150 do Código Penal ${ }^{485}$ ). Se o sujeito passivo estiver de acordo, o crime não se configura. Segundo Manuel da Costa Andrade ${ }^{486}$, os crimes sexuais são semelhantes à invasão de domicílio, pois “também aqui o bem jurídico protegido assume a natureza de

\footnotetext{
481 Para Alessandra Greco "é aplicável a teoria da autocolocação em risco e do consentimento como excludentes da imputação nos crimes de tráfico de pessoas, desde que se considere, além dos requisitos gerais desses institutos, como a capacidade e o poder de discernimento, a condição de fragilidade, ou não, daquele que é conduzido pelo agente". Da autocolocação da vítima em risco e o tráfico de pessoas. In: MARZAGÃO JÚNIOR, Laerte I. Tráfico de pessoasI, p. 31.

${ }^{482}$ A quem consente não é feita injúria.

${ }^{483}$ SILVEIRA, Renato de Melo Jorge. Crimes sexuais, p. 221.

${ }^{484}$ POLAINO-ORTS, Miguel. Alegato en favor de un tratamiento jurídico-penal unitario para los casos de acuerdo y consentimiento como causas de atipicidad. Cuadernos de Política Criminal, n. 82, p. 164.

485 “Art. 150. Entrar ou permanecer, clandestina ou astuciosamente, ou contra a vontade expressa ou tácita de quem de direito, em casa alheia ou em suas dependências: Pena - detenção, de um a três meses, ou multa". 486 COSTA ANDRADE, Manuel da. Consentimento e acordo em direito penal: contributo para a fundamentação de um paradigma dualista, p. 382-383.
} 
uma forma concreta de liberdade, por vezes referida como autodeterminação sexual e que talvez pudesse, com igual propriedade, nomear-se como liberdade e autenticidade da expressão sexual".

Segundo essa teoria, o consentimento (Einwilligung) exclui a antijuridicidade, pois apesar deste, a lesão existiu. O exemplo seria o crime de dano, pois mesmo que o titular do bem consinta em sua destruição, a lesão ocorreu, e, por conseguinte, o crime. Assim, só caberia a justificação.

Defensor dessa teoria, Costa Andrade ${ }^{487}$ afirma que apesar da necessária superação do paradigma originário de Geerds, "tudo parece reforçar a plausibilidade dogmática da distinção e contraposição, em termos renovados, de um consentimento justificante ${ }^{488}$ e de um acordo que afasta a tipicidade".

Em sentido contrário, segundo Polaino-Orts ${ }^{489}$ tal distinção não é apenas dogmaticamente improdutiva como também incorreta, pois concede a tais figuras um tratamento diferenciado sob o pretenso argumento de o acordo ser mais factível que o consentimento e de uma preponderância da disponibilidade do bem jurídico nos casos em que cabe o acordo. Para o autor, acordo e consentimento são sinônimos e devem receber o mesmo tratamento dogmático.

b) unitária ou da atipicidade: essa corrente considera supérflua a distinção entre acordo e consentimento, e entende que o consentimento exclui o tipo.

Para esse trabalho adota-se a teoria unitária, com vistas à exclusão da tipicidade quando presente o consentimento válido.

\footnotetext{
${ }^{487}$ COSTA ANDRADE, op. cit., p. 516.

${ }^{488}$ Jorge de Figueiredo Dias afirma que nem todos os complexos problemas relacionados à questão "tenham que ser definitiva e completamente resolvidos em sede de consentimento como causa de justificação; mas significa que uma sua eventual justificação passa pelo (ou não pode pelo menos abstrair do) estatuto do consentimento como causa de exclusão de ilicitude”. In: Direito penal: parte geral, p. 478.

${ }^{489}$ POLAINO-ORTS, op. cit., p. 197.
} 
Para Polaino-Orts ${ }^{490}$, justamente pela razão do sujeito passivo desfrutar de um âmbito de autonomia e liberdade sobre a gestão dos bens jurídicos de sua titularidade, o consentimento, desde que válido, excluirá ab initio qualquer incidência lesiva.

Nesse sentido, para Alessandra Greco ${ }^{491}$, tendo em vista a teoria da imputação objetiva, o mais acertado seria incluir o consentimento nas causas de exclusão da tipicidade. Segundo Renato Silveira ${ }^{492}$, em que pese entendimento no sentido de que o consentimento possa gerar uma causa de exclusão da ilicitude, "mais recentemente, tem-se sedimentado a tendência em se considerar que, na totalidade das situações em que se verifica um consentimento válido, se estaria, de fato, diante de uma excludente de tipicidade".

c) diferenciadora: essa corrente também diferencia acordo e consentimento. $\mathrm{O}$ primeiro acarretará na atipicidade e o segundo pode ser tanto causa de atipicidade como excludente de antijuridicidade.

No Brasil, o Código Criminal de 1830 não trazia qualquer menção ao consentimento do ofendido. Já o Código Penal da República, de 1890, dispunha: “Art. 26. Não dirimem, nem excluem a intenção criminosa: [...] c) o consentimento do ofendido, menos nos casos em que a lei só a ele permite ação criminal”.

Esse dispositivo foi duramente criticado por confundir institutos diversos, uma vez que o consentimento visa à exclusão do crime, enquanto o não exercício do direito de queixa exclui a punibilidade ${ }^{493}$.

A Parte Geral do Código Penal de 1940 também não traz disposição relativa ao consentimento, nem em sua versão original, nem após o advento da Lei n. 7.209, de 1984. O tema foi tratado pelo Projeto Alcântara Machado, no art. 14: "Não será também punível aquele que praticar ação ou omissão: I - com consentimento de quem possa validamente

\footnotetext{
${ }^{490}$ POLAINO-ORTS, op. cit., p. 198.

${ }^{491}$ GRECO. A autocolocação da vítima em risco, p. 100.

${ }^{492}$ SILVEIRA, op. cit., p. 230.

${ }^{493}$ PIERANGELI, José Henrique. O consentimento do ofendido na teoria do delito, p. 90-92.
} 
dispor do direito violado ou ameaçado"494, mas descartado quando da aprovação do texto final.

Na Parte Especial do Código Penal existem delitos cuja estrutura típica inclui o consentimento $^{495}$, como acontece com o já mencionado art. 150 , e, de forma diferente, no delito de aborto. Presente o consentimento da gestante (art. 126), o crime se configura, mas com pena de reclusão de 1 a 4 anos, menor que a do delito do art. 125, em que não há esse consentimento e a pena é de reclusão de 3 a 10 anos.

Não obstante esses exemplos, como no Brasil não existe norma expressa quanto aos limites de aceitação do consentimento, em muitos crimes, como nos sexuais, mesmo que a pretensa vítima consinta, o texto da lei impede a incidência exculpante ${ }^{496}$. É o que acontece com o tráfico de pessoas conforme previsto no art. 231 do Código Penal.

Segundo Renato Silveira ${ }^{497}$, no caso de a pretensa vítima ser favorável à atuação do agressor, a ação torna-se aceitável e tolerável, fora do âmbito de atuação do direito penal. Trata-se de conduta atípica. Para tanto, o consentimento deve revelar-se ou como parte da estrutura típica ou o tipo deve mencionar a necessidade do consentimento ou dissentimento $^{498}$.

\title{
7.2 O CONSENTIMENTO DA VÍTIMA NO TRÁFICO DE PESSOAS PARA FIM DE EXPLORAÇÃO SEXUAL E A QUESTÃO DA VULNERABILIDADE
}

\begin{abstract}
"Eu gosto de trabalhar na prostituição. Há pessoas que dizem que é um dinheiro fácil. Não é que é um dinheiro fácil. Mas, pelo menos você tem mais oportunidade de conseguir mais dinheiro. Se você quer mais dinheiro, você trabalha mais horas. Nossa vantagem é que você é livre. Você faz o que você quer!"
\end{abstract}

"Ele (o dono do clube) cobrava a diária e o resto o que você fizesse era seu. Eles cobravam 40 euros a diária. [...] Eu cheguei a fazer 400 em uma noite. [...] Porque para mim era até uma diversão, tenho até umas amigas e sempre falamos

\footnotetext{
494 A justificativa da exclusão do dispositivo pela Comissão Revisora é de que este era supérfluo. PIERANGELI, op. cit., p. 92.

${ }^{495}$ Idem, p. 96-97.

${ }^{496}$ SILVEIRA, op. cit., p. 223.

${ }^{497}$ Idem, p. 227.

${ }^{498}$ Idem, p. 226-227.
} 
nisso, que a gente perdeu muito dinheiro porque a gente se sentava e passava toda a noite conversando".

"Você fazendo a prostituição aqui você aprende muita história, muita cultura diferente. A mim me encanta. Porque você convive também com os franceses, com os ingleses, com alemães, com os gregos. Então, quando eu saio daqui e vou para o Brasil e você começa a conversar com as pessoas, você vai vendo a grandeza que você tem em termos de cultura".

Essas declarações foram dadas por brasileiras que exercem a prostituição na Espanha à pesquisadora Adriana Piscitelli ${ }^{499}$, nos anos de 2004 e 2005. Deixam claro que nem toda a prostituição exercida no exterior é forçada. Pode existir consentimento válido para esses casos, e, apenas nessas ocasiões, entende-se que o crime deve ser excluído.

Segundo lição de Silveira ${ }^{500}$, é inadmissível o Estado considerar que uma pessoa adulta não possa atuar livremente quanto ao sexo. Para o autor, seja na forma de paternalismo ou simples moralismo, deve ser repudiada a restrição da liberdade de adultos pela mera suposição de não serem aptos à livre escolha sobre como agir.

Definir o que sejam bens jurídicos disponíveis e indisponíveis é tarefa árdua, e possivelmente inalcançável. Conforme preceitua Pierangeli ${ }^{501}$, não há critério seguro que permita concluir pela disponibilidade ou não do bem jurídico. $O$ autor cita algumas possibilidades, porém todas apresentam falhas ${ }^{502}$. A análise dar-se-á, então, tendo em vista os princípios penais vigentes em um Estado Democrático de Direito, fincado no superprincípio da dignidade humana.

\footnotetext{
${ }^{499}$ PISCITELLI, Adriana. Sujeição ou subversão: migrantes brasileiras na indústria do sexo na Espanha. In: Revista Histórias e Perspectivas, n. 35. Uberlândia, jul.-dez. 2006. Disponível em: $<$ http://www.historiaperspectivas.inhis.ufu.br/index.php>. Acesso em: 5 jan. 2011. A pesquisa foi feita com prostitutas de rua, clubes e pisos. A maioria delas já havia se prostituído no Brasil, profissional ou ocasionalmente. Ao exercerem outros ofícios no País, consideravam que o salário não compensava os esforços. A maioria migrou com a intenção de se prostituir. Algumas foram para trabalhar em outros serviços, mas os baixos salários oferecidos aos migrantes irregulares, somado à jornada extenuante as fizeram optar pela prostituição - considerada um trabalho como qualquer outro. Só conseguiram regularizar a situação na Espanha as mulheres que se casaram com espanhóis, clientes ou não.

${ }^{500}$ SILVEIRA, op. cit., p. 150.

${ }^{501}$ PIERANGELI, op. cit., p. 120-121.

502 1) a distinção se faz tendo-se em vista a utilidade social do bem; 2) em caso de ação penal pública, presume-se bem indisponível, e, no caso de ação privada, presume-se bem disponível. José Pierangeli, op. cit., p. 119.
} 
Não se entrará aqui em discussões maiores como a validade do consentimento para bens indisponíveis, como a vida. O escopo deste trabalho é tratar do consentimento para os bens jurídicos disponíveis, dos quais, entende-se, a liberdade sexual faz parte.

Adotamos para esse estudo a definição de bem disponível como aquele em que seu titular pode abrir mão como exercício de sua autonomia, sem que ocorra a lesão a terceiros.

Anabela Miranda Rodrigues ${ }^{503}$, ao comentar o tráfico de pessoas na evolução do direito português, afirma que "manifestamente excessiva, ultrapassando a função do direito penal, era a proteção de pessoas em face de manobras de aliciamento para a prática da prostituição ou de atos contrários ao pudor ou à moralidade sexual que não envolvessem violência, ameaça grave, ardil ou manobra fraudulenta".

Na lição de $\mathrm{Nucci}^{504}$, havendo o consentimento do ofendido, ficaria superada a lesão à liberdade sexual, restando somente a moralidade e os bons costumes, que não merecem guarida penal, tendo em vista o princípio da intervenção mínima.

Pierangeli ${ }^{505}$, ao cotejar o consentimento e os bons costumes, afirma que é necessário valorar individualmente a validade do consentimento em face da moral social em dado momento histórico, pois o juízo de moralidade é sempre relativo, dependente das circunstâncias. Essa questão é muito importante para o crime em tela, pois o consentimento apenas será levado em conta quando se tratar de bem jurídico individual. Quando o bem jurídico é difuso ou coletivo, o delito não pode ser afastado pela vontade de apenas um indivíduo.

Nesse passo, poder-se-ia afirmar que o bem jurídico tutelado no crime de tráfico de pessoas seria os bons costumes e a moral sexual da coletividade. Contudo, o bem jurídico protegido pelo direito penal sexual não pode ser esse, e sim a liberdade sexual, bem próprio e personalíssimo de seu titular ${ }^{506}$.

\footnotetext{
${ }^{503}$ DIAS, Jorge de Figueiredo (dir.). Comentário Conimbricense do Código Penal: Parte Especial, p. 511512.

${ }^{504}$ NUCCI, Guilherme de Souza. Crimes contra a dignidade sexual, p. 158.

${ }^{505}$ PIERANGELI, op. cit., p. 126-127.

${ }^{506}$ SILVEIRA, op. cit., p. 222.
} 
A Lei n. 12.015, de 2009, vem corroborar esse entendimento, ao alterar a denominação dos crimes contra os costumes para crimes contra a dignidade sexual, em que se inclui o crime de tráfico de pessoas.

Não obstante a alteração da nomenclatura, os manuais, em sua maioria, apenas afirmam que o consentimento é indiferente, sem questionar a validade dessa norma em face do princípio da intervenção mínima do direito penal. As questões que envolvem consentimento, adequação social, autocolocação da vítima em risco, ainda aparecem de forma muito acanhada também no Judiciário.

Para Renato Silveira ${ }^{507}$, o consentimento será considerado válido sempre que não exceder os limites da proteção penal fundados no princípio da dignidade humana, dentro da sociedade pluralista presente.

Em sentido contrário, Rogério Sanches ${ }^{508}$ entende que o consentimento da vítima não elide a responsabilidade do agente, pois o bem jurídico tutelado - a dignidade sexual é indisponível.

A juíza argentina Zunilda Niremperger ${ }^{509}$ relata que ao enfrentar casos concretos sobre o tráfico de pessoas reviu alguns posicionamentos dogmáticos como o consentimento da vítima. Ela conclui que o consentimento só deve afastar a incidência do tipo penal quando as situações socioeconômicas e culturais da vítima permitam comprovar que foi uma escolha realmente livre. Essa postura se deve ao fato de ter-se deparado com vítimas extremamente vulneráveis, em situação de pobreza e exclusão social, oriundas de famílias desestruturadas, que, caso tenham consentido, foi em um contexto de necessidade extrema e falta de opção o que vicia completamente a decisão.

O consentimento pode ser viciado por diversos fatores, como a violência, a ameaça, o engodo, o abuso de autoridade ou de uma situação de vulnerabilidade. Especialmente o

\footnotetext{
${ }^{507}$ SILVEIRA, op. cit., p. 224.

${ }^{508}$ CUNHA, Rogério Sanches et. al. Comentários à reforma criminal de 2009 e à Convenção de Viena sobre o Direito dos Tratados, p. 81.

${ }^{509}$ NIREMPERGER, Zunilda; RONDAN; Francisco. Mercaderes de vida: una visión histórica, sociológica y jurídica del delito de trata de personas, p. 19. Conforme a legislação vigente na Argentina, o consentimento é admitido no crime de tráfico de pessoas.
} 
conceito de vulnerabilidade, por ser muito amplo, deve ser enfrentado com cuidado especial.

Não existe um conceito pacífico para vulnerabilidade no contexto específico do tráfico de pessoas. Muitas vezes o termo chega a ser utilizada como sinônimo de pobreza, o que se mostra inadequado, pois a vulnerabilidade pode se apresentar como qualquer fator que dificuldade ou impeça que a vítima rechace a exploração a que é submetida.

A UN.GIFT e o UNODC ${ }^{510}$ propõem um conceito de vulnerabilidade nos seguintes termos:

\begin{abstract}
Vulnerabilidade refere-se a uma condição resultante da forma como os indivíduos experimentam negativamente a interação complexa de fatores sociais, culturais, econômicos, políticos e ambientais que criam o contexto de suas comunidades. Como tal, a vulnerabilidade não é um estado estático, absoluto, mas que muda de acordo com o contexto, bem como à capacidade de resposta individual. (tradução nossa ${ }^{511}$ )
\end{abstract}

O UNODC elaborou um "modelo de lei contra o tráfico de pessoas" "512, onde discute o conceito de vulnerabilidade, e muitas são as possibilidades e sugestões. Segundo o documento, o abuso de uma situação de vulnerabilidade pode referir-se a qualquer situação na qual a pessoa envolvida acredite que não exista alternativa possível ou aceitável que não seja submeter-se. Outra forma de apresentar a questão seria afirmar que o abuso de uma posição de vulnerabilidade surge como resultado de uma situação especial da vítima, como: $a$ ) ter entrado ilegalmente no país; $b$ ) gravidez ou alguma doença física ou mental, ou ainda incapacidade gerada pelo vício em substância entorpecente; $c$ ) menoridade; $d$ ) promessa ou concessão de pagamento ou vantagem à pessoa que tem autoridade sobre a vítima; $e$ ) situação econômico-social precária, etc.

Assim, entende-se que a reforma da legislação brasileira deve abranger a proteção da vítima vulnerável, pois o seu consentimento não é válido. A vulnerabilidade que

\footnotetext{
510 An introduction to Human Trafficking: Vulnerability, Impact and Action. Disponível em: $<$ http://www.ungift.org/knowledgehub/publications.html?vf=/doc/knowledgehub/resourcecentre/GIFT_Intro_to_Human_Trafficking_background_paper_2008.pdf>. Acesso em: 15 ago. 2011.

511 "Vulnerability" refers to "a condition resulting from how individuals negatively experience the complex interaction of social, cultural, economic, political, and environmental factors that create the context for their communities". As such, vulnerability is not a static, absolute state, but one that changes according to context as well as to the capacity for individual response.
512 Disponível em:
$<$ http://www.unodc.org/documents/human-

trafficking/UNODC_Model_Law_on_Trafficking_in_Persons.pdf>. Acesso em: 15 ago. 2011.
} 
interessa a esse estudo é da pessoa maior e capaz, e a sua compreensão deve ser despida de preconceitos. Ou seja, a prostituição voluntária deve ser considerada válida, pois na verdade é um exercício da autonomia justamente nos casos de pessoa maior e capaz.

De outro lado, deve ser considerada vulnerável a pessoa que aceitou se prostituir no exterior por não ter nenhuma outra opção viável, e o seu consentimento não corresponde à sua vontade real. Para Rosario Serra Cristóbal ${ }^{513}$, a vulnerabilidade pode ser entendida como aquela situação na qual a pessoa não tem outra opção real e aceitável que não seja submeter-se à vontade de quem quer explorá-la. A vulnerabilidade pode se apresentar de forma psíquica, física, afetiva, familiar, social ou econômica, e nestes casos estará configurado o delito ${ }^{514}$. Essa modalidade certamente enfrentará uma grande dificuldade na questão de prova, precisamente por tratar-se de pessoa maior e capaz.

Para João Paulo Martinelli ${ }^{515}$, o vulnerável é a pessoa a quem o Estado precisa dar maior atenção para que tenha uma vida mais digna, pois a sua fragilidade a impede de fazê-lo por conta própria. Assim, tendo em vista os limites de criminalização, a tutela penal do vulnerável somente é legítima quando a vulnerabilidade proporcionar uma relação de exploração capaz de provocar prejuízos ao mais frágil na relação. Ou seja, não deve haver presunção juris et de jure de vulnerabilidade como acontece hoje no Código Penal brasileiro, art. 231.

Merecem destaque também os casos em que há um consentimento ou cooperação inicial entre a vítima e os traficantes, seguido logo depois de uma situação de coação, abuso ou exploração. Todo consentimento inicial é efetivamente anulado quando começam a imperar esses vícios ${ }^{516}$.

\footnotetext{
${ }^{513}$ SERRA CRISTÓBAL, Rosario; LLORIA GARCÍA, Paz. La trata sexual de mujeres: de la represión del delito a la tutela de la víctima, p. 166.

${ }^{514}$ Nesse sentido: RASSI, João Daniel. A questão da vulnerabilidade no direito penal sexual brasileiro. (no prelo)

${ }_{515}$ MARTINELLI, João Paulo Orsini. Tráfico de pessoas e consentimento: uma breve reflexão. Boletim IBCCrim, n. 221, p. 7.

${ }^{516}$ Elena Florencia Onassis afirma que: "Efectivamente, el consentimiento de la víctima em uma etapa del processo de Trata no puede considerarse valido en el resto de las etapas, y resulta poco probable pensar que uma persona brinde su consentimiento para ser explotada, teniendo em cuenta que toda forma de explotación implica abusos, torturas y otros vejámenes”. In: Trata de personas: la esclavitud del siglo XXI, p. 126-127.
} 
Segundo Rosario Serra Cristóbal ${ }^{517}$, existem situações em que a vítima consentiu inicialmente a exercer a prostituição no exterior. Porém, chegando ao local de destino sofre abusos e graves atentados a sua dignidade e demais direitos fundamentais. Nesses casos, a consideração de que o consentimento é irrelevante adquire todo o sentido.

Nos bordéis a praxe é desestabilizar o espírito das vítimas por meio de humilhações, estupros, ameaças e toda sorte de violência. Nessa situação, ceder à vontade do proprietário do bordel não significa consentir ${ }^{518}$.

Precisa ser esclarecido que nem sempre o tráfico de pessoas consistirá em escravização de suas vítimas, com a consequente violação de direitos humanos. Porém, existem situações limítrofes, que precisam ser avaliadas individualmente. Isso fica claro no exemplo de Adriana Piscitelli ${ }^{519}$, que cita as brasileiras que vão voluntariamente para a Espanha e apenas têm que pagar a passagem para os traficantes. Mesmo que o valor a ser pago seja exorbitante, não corresponde necessariamente a uma violação de direitos humanos. Devem ser avaliados a natureza do engano, o contexto da exploração e o grau de coerção.

A advogada e fundadora da ASBRAD, Dalila Figueiredo ${ }^{520}$, relata a experiência do Posto de Atendimento Humanizado a Deportados e Inadmitidos no Aeroporto Internacional de Guarulhos. Quando as deportadas ou inadmitidas são atendidas pelo Posto, logo associam o tráfico à ideia de alguma "máfia". Afirmam que isso não acontece com as brasileiras, que são vistas como independentes, e sim com as mulheres do leste europeu. Não entendem o pagamento excessivo pela viagem, alimentação e hospedagem como elementos caracterizadores do tráfico, e sim como algo natural, a retribuição por um investimento prévio, visto como ajuda.

\footnotetext{
${ }^{517}$ SERRA CRISTÓBAL e LLORIA GARCÍA, op. cit., p. 167.

${ }^{518}$ KRISTOF, Nicholas; WUDUNN, Sheryl. Metade do céu, p. 36.

${ }^{519}$ PISCITELLI, Adriana. Entre as "máfias" e a "ajuda": a construção de conhecimento sobre tráfico de pessoas. Cadernos Pagu, p. 57.

${ }_{520}$ FIGUEIREDO, Dalila. Relato de uma experiência - o Posto de Atendimento Humanizado a Deportados e Inadmitidos no Aeroporto Internacional de Guarulhos. In: LANDINI, Tatiana Savoia; OLIVEIRA, Marina P. P. (org.). Enfrentamento ao tráfico de pessoas, p. 102.
} 
Segundo Piscitelli ${ }^{521}$, a condição de vulnerabilidade das prostitutas pesquisadas na Espanha é maior no país de destino do que no Brasil. A situação de migrante ilegal faz com que haja uma submissão às situações de exploração, como no pagamento da passagem, hospedagem e alimentação a valores exorbitantes.

Dessa forma, até que ponto esse proveito econômico excessivo pode ser considerado exorbitante e tutelado criminalmente, se as pretensas vítimas entendem que se trata da lógica desse mercado?

Veja-se o depoimento de uma prostituta que exerce o ofício há 5 anos e sintetiza a opinião das entrevistadas por Piscitelli ${ }^{522}$ na Espanha:

\begin{abstract}
"Máfias... que a polícia te mostre uma única máfia que seja! Nem duas, nem três, isso não existe. $O$ que fazem é deportar mulheres sem papéis, que sabiam o que vinham a fazer aqui, que queriam fazer isso! O que é uma máfia? É cobrar o dobro por uma passagem? Isso não é máfia, isso é algo que acontece. Você quer vir para Europa, mas não tem dinheiro para a passagem. A passagem custa 1000 euros, eu compro para você, porque eu tenho o dinheiro, mas cobro 3000 . Você aceitou, pronto, feito. Máfia é quando tem uma mulher como escrava, prisioneira, quando a vendem. Isso tem aqui, com as romenas. Mas, a polícia prende elas e não os homens que estão na calçada da frente controlando! E elas têm que trabalhar queiram ou não, não podem parar para comer, ou tem que comer o que eles dão para elas. Isso é máfia, com brasileira não tem isso não".
\end{abstract}

Conforme o exposto, são muitas as peculiaridades do tráfico. Apenas no caso a caso será possível avaliar se o consentimento é válido ou não para excluir a tipicidade da conduta. Mas, não obstante a dificuldade atinente à questão da prova, entende-se que cabe ao legislador brasileiro alterar a legislação e conceder a prerrogativa de escolha às mulheres que querem exercer a prostituição no exterior e são auxiliadas para tanto, sob pena de se demonstrar demasiado paternalista.

\footnotetext{
${ }^{521}$ PISCITELLI, Adriana. Tráfico de pessoas e mercado do sexo. In: LANDINI, Tatiana Savoia; OLIVEIRA, Marina P. P. (org.). Enfrentamento ao tráfico de pessoas, p. 40.

${ }^{522}$ PISCITELLI, Adriana. Sujeição ou subversão: migrantes brasileiras na indústria do sexo na Espanha. In: Revista Histórias e Perspectivas, n. 35. Uberlândia, jul.-dez. 2006. Disponível em: $<$ http://www.historiaperspectivas.inhis.ufu.br/index.php>. Acesso em: 5 jan. 2011.
} 


\section{CONCLUSÕES}

Durante a pesquisa, seja por meio de relatos de profissionais envolvidos, depoimentos de vítimas ou documentários sobre o tema, o que se pôde constatar é que se trata de um crime praticamente invisível e, até certa medida, desprezado pelo direito penal. Ainda são poucos os autores que se debruçam sobre a questão.

Enquanto seres humanos são considerados apenas estatísticas, não têm rosto, nome ou história, é mais fácil tolerar a situação. Contudo, após ler e assistir tantos relatos, é impossível ficar indiferente a esse crime, que precisa ser expurgado de todas as nações.

Do presente trabalho, com base no direito penal mínimo, extraem-se as seguintes conclusões:

1. O tráfico internacional de pessoas para fim de exploração sexual não se esgota em um dispositivo penal. É um fenômeno complexo e multidisciplinar, que exige a participação de várias esferas estatais e da sociedade civil para ser prevenido e punido adequadamente.

2. Não existem hoje estatísticas ou pesquisas abrangentes e confiáveis para informar números ou características precisas relativas ao tráfico de pessoas. $\mathrm{O}$ que se pode afirmar é que o delito está presente em todos os continentes e envolve graves violações aos direitos humanos.

3. O bem jurídico tutelado pelo direito penal sexual e, como consequência, no tráfico de pessoas para exploração sexual é a liberdade sexual, devendo ser afastada a proteção da moralidade pública sexual. Assim, o bem jurídico tutelado nos delitos sexuais é individual e não coletivo.

4. A prostituição voluntária, de pessoa maior e capaz que consente validamente no ofício, não pode ser considerada forma de exploração sexual. Apenas a prostituição 
forçada deve ser considerada exploração. É postura excessivamente paternalista não oferecer ao cidadão a prerrogativa de escolha do seu trabalho.

5. Não podemos classificar como prostitutas as mulheres que são reiteradamente violentadas nos bordéis. Elas são escravas. Prostitutas recebem pagamento pelo seu ofício.

6. É necessário definir o que significa exploração sexual. Esse vazio legislativo dá margem a interpretações díspares.

7. Sendo lícito o exercício da prostituição, condutas como seu induzimento ou facilitação não devem ser criminalizadas. Ou seja, os tipos descritos no capítulo do Código Penal referente ao lenocínio devem ser descriminalizados sempre que não houver vício de consentimento, como violência, erro, ameaça ou fraude.

8. O consentimento válido da vítima elimina a situação de risco proibido, portanto não há tipicidade, e consequentemente não há crime. A teoria do consentimento adotado por este trabalho é a unitária.

9. Quando se tratar de pessoa maior e capaz, que tenha aderido livremente ao deslocamento de um país a outro com o fim de exercer a prostituição, sem qualquer forma de abuso, violência ou coação, conquistando ela própria certa vantagem com o ato, não há crime. Todos os bens jurídicos envolvidos nesse caso são disponíveis.

10. A avaliação do consentimento no crime de tráfico de pessoas ainda se encontra eivada por questões morais e paternalistas. O Brasil deve atualizar sua legislação nesta seara, como fizeram Portugal e Espanha, por exemplo.

11. A legislação brasileira está em falta com os Protocolos adicionais à Convenção de Palermo. O País se comprometeu a criminalizar as condutas ali previstas, porém, até o momento, o que temos é um emaranhado de dispositivos dispersos, sem sistematização ou proporcionalidade entre as penas. Além disso, os projetos que estão em tramitação no Congresso Nacional se apresentam de forma incompleta e assistemática. 
12. Sem a cooperação internacional e sem a implementação efetiva de uma política interna de enfrentamento ao tráfico de pessoas, que adote um trabalho em rede, incluindo entidades estatais e a sociedade civil, não haverá a prevenção ao crime, a punição dos traficantes e exploradores e a proteção e assistência às vítimas.

13. Com o fim principal de proteger a vítima do tráfico de pessoas, é necessário distinguir corretamente entre tráfico de pessoas para fim de exploração e para migração ilegal.

14. Para que se faça a adequada proteção e atenção às vítimas do tráfico, deve-se fornecer treinamento específico aos policiais, agentes de fronteira ou alfandegários, pessoal da área da saúde, entre outros, a fim de que a vítima de tráfico não seja revitimizada.

15. Um trabalho efetivo de prevenção ao tráfico é a arma mais eficaz em seu combate. Para tanto, é necessário implementar políticas públicas e sociais conforme previsto no art. $6^{\circ}$ da Constituição Federal, como educação, trabalho e moradia. 


\section{ANEXO - Mapas e Gráficos}

Mapa 1 - Mulheres traficadas para a Europa com fim de exploração sexual (cidadania das vítimas detectadas), 2005-2007

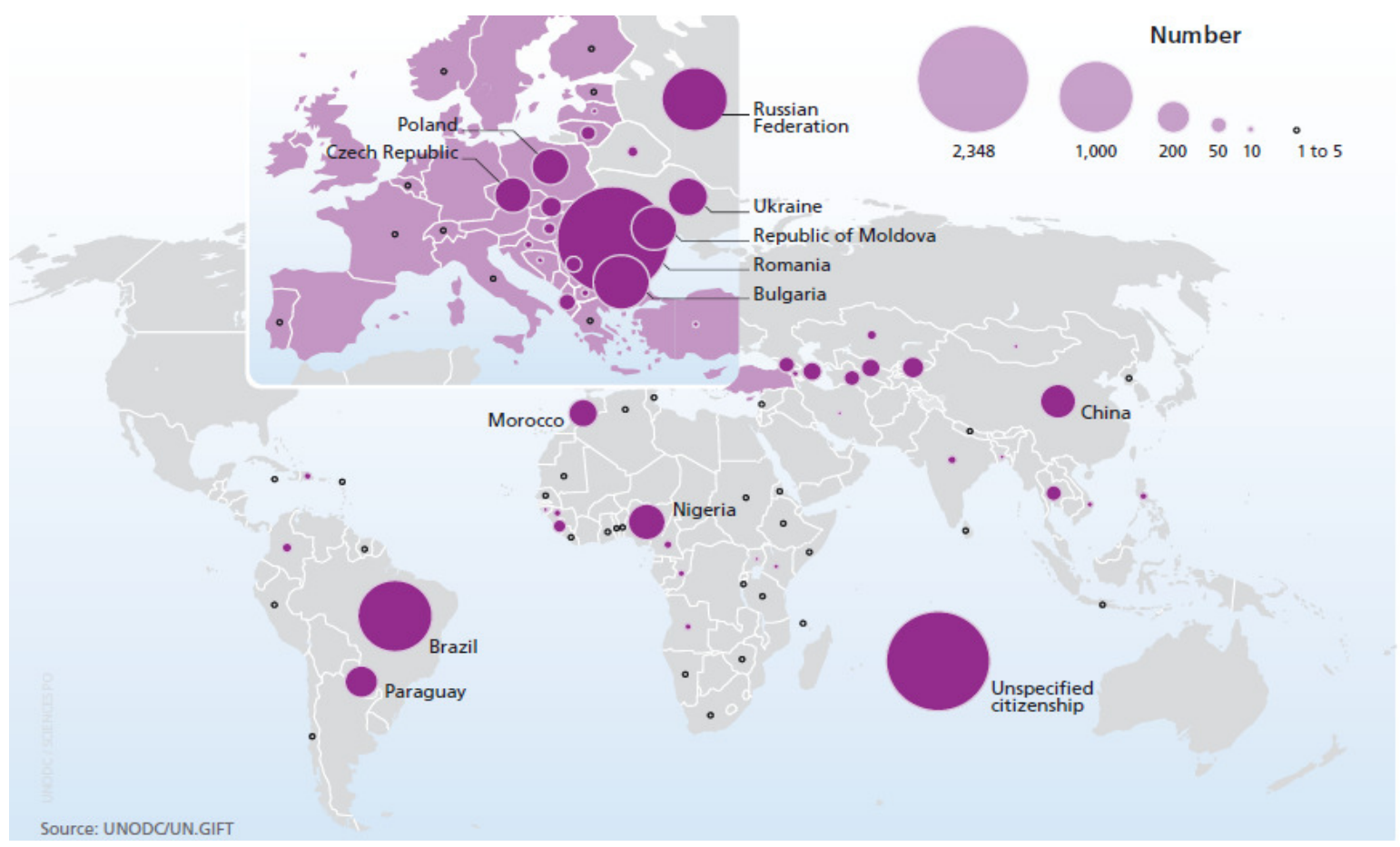

Fonte: Trafficking in persons to Europe for sexual exploitation.

Disponível em: <http://www.unodc.org/southerncone/pt/trafico-de-pessoas/publicacoes.html>.

Mapa 2 - De onde partem e para onde vão as vítimas

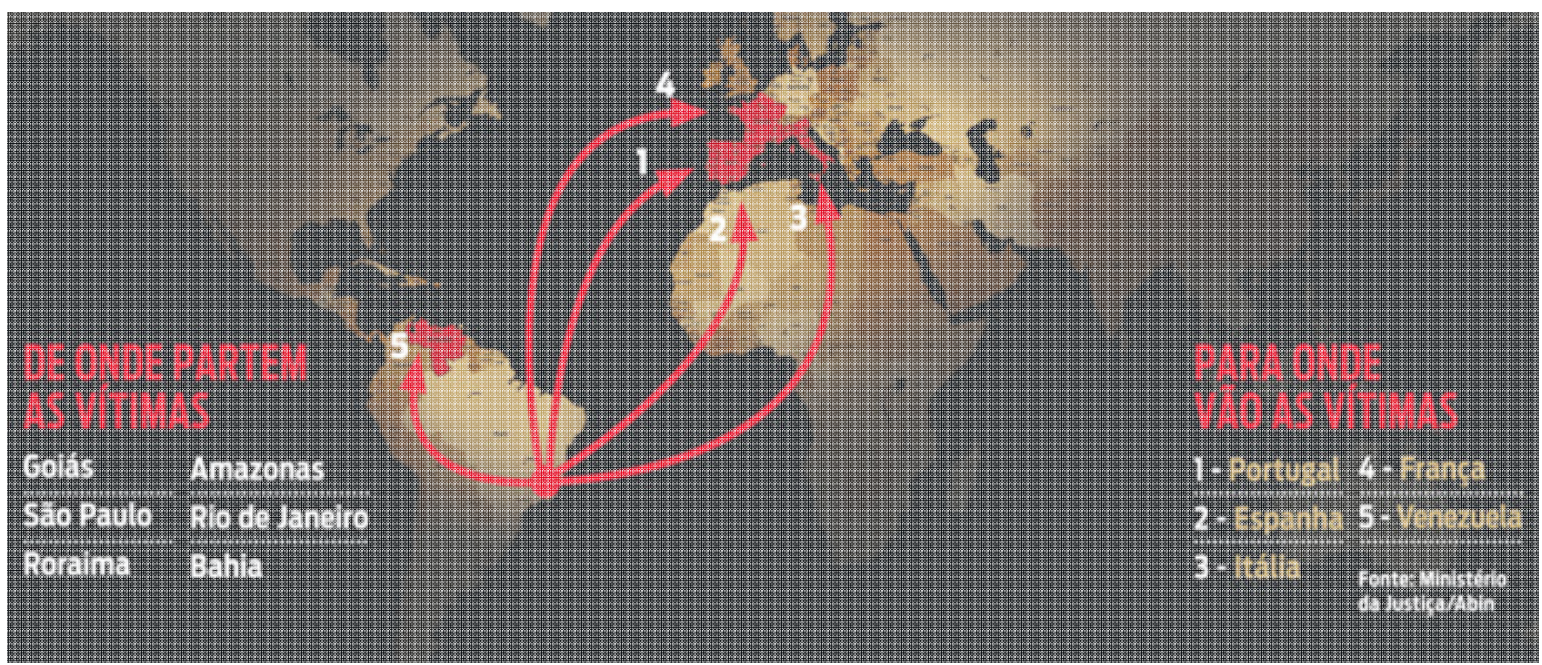

Fonte: TORRES, Izabelle; COSTA, Flávio. Tráfico de pessoas. Revista Isto é, edição 2.189, 21 out. 2011. Disponível em: $<$ http://www.istoe.com.br/reportagens/170188_TRAFICO+DE+PESSOAS?pathmagens=\&path=actualArea=internalPage > . 
Gráfico 1 - Nacionalidade das vítimas de tráfico detectadas na Europa Ocidental e Central, (\%), 2005-2006

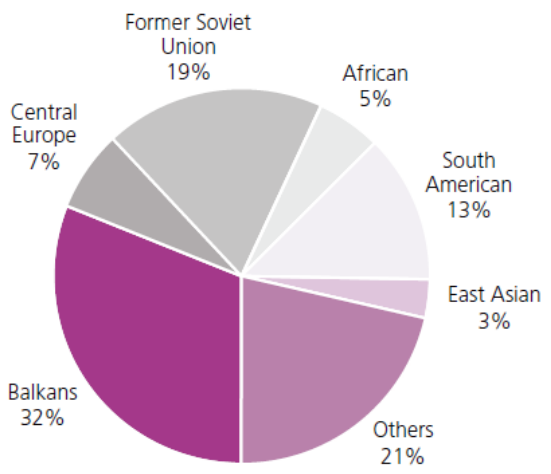

Source: Elaboration of UNODC/UN.GIFT data

Fonte: Trafficking in persons to Europe for sexual exploitation.

Disponível em: <http://www.unodc.org/southerncone/pt/trafico-de-pessoas/publicacoes.html>.

Gráfico 2 - Colombianas, brasileiras e paraguaias vítimas do tráfico na Espanha

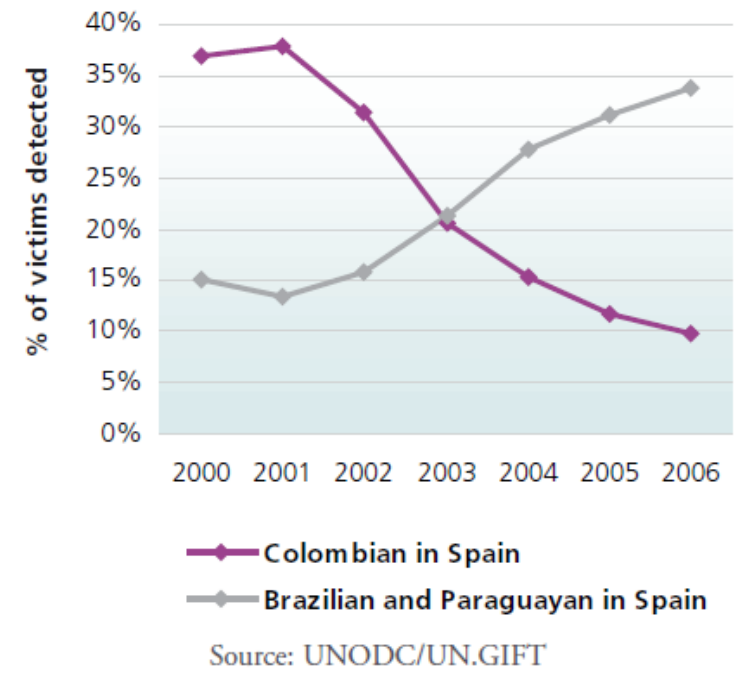

Fonte: Trafficking in persons to Europe for sexual exploitation.

Disponível em: <http://www.unodc.org/southerncone/pt/trafico-de-pessoas/publicacoes.html>. 
Gráfico 3 - Tráfico de trabalho forçado por tipo

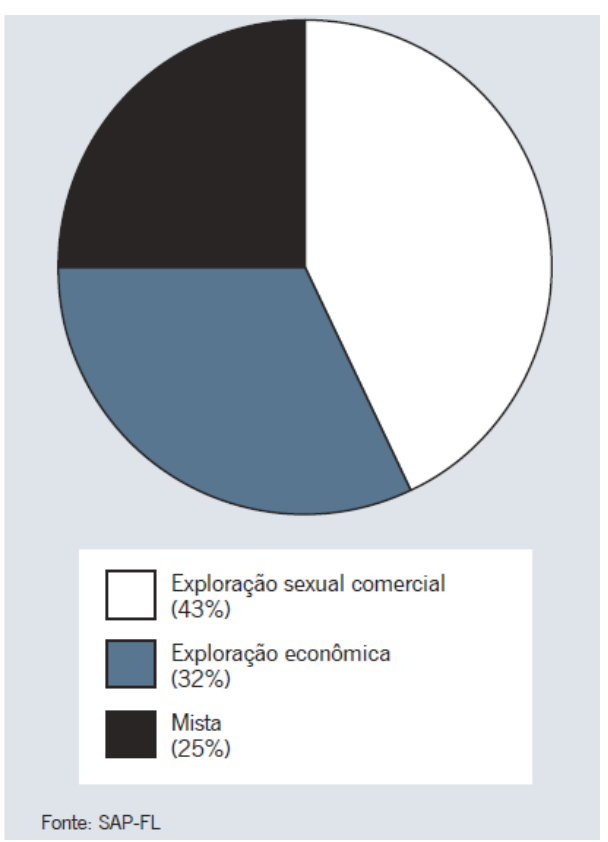

Fonte: Relatório Global do Seguimento da Declaração da OIT sobre Princípios e Direitos Fundamentais no Trabalho, 2005. Disponível em:

<http://www.oit.org.br/sites/default/files/topic/forced_labour/pub/relatorio_global_2005_alianca_contra_trabalho_forcad o_316.pdf>.

\section{Gráfico 4}

Exploração econômica forçada por sexo

Exploração sexual comercial forçada por sexo

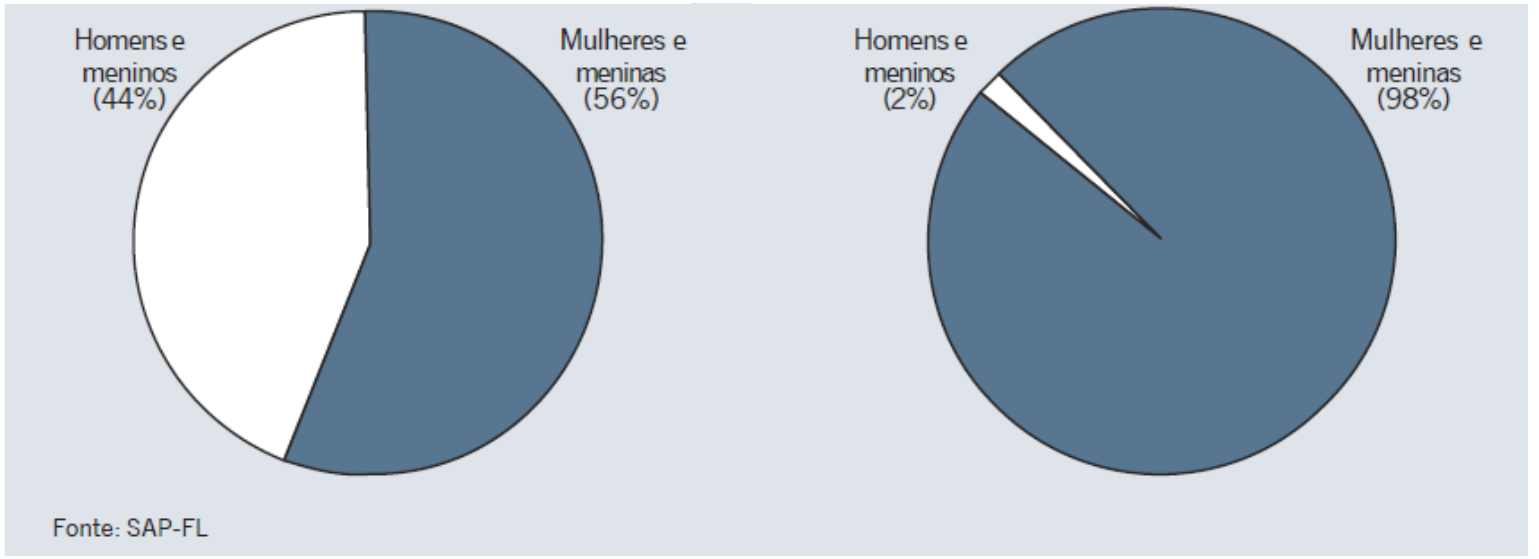

Fonte: Relatório Global do Seguimento da Declaração da OIT sobre Princípios e Direitos Fundamentais no Trabalho, 2005. Disponível em:

$<$ http://www.oit.org.br/sites/default/files/topic/forced_labour/pub/relatorio_global_2005_alianca_contra_trabalho_forcad o_316.pdf>. 


\section{REFERÊNCIAS}

\section{Livros, Teses, Dissertacões e Pesquisas:}

I PRÊMIO Libertas: Enfrentamento ao Tráfico de Pessoas. Série Pesquisas e Estudos. Ministério de Justiça/SNJ, Brasília: 2010.

ALBRECHT, Hans-Jörg. Criminalid transnacional, comercio de narcóticos y lavado de dinero. Trad. Oscar Julián Guerrero Peralta. Bogotá: Universidad Externado de Colombia, 2001.

ARY, Thalita Carneiro. O tráfico de pessoas em três dimensões: evolução, globalização e a rota Brasil-Europa. 2009. 158 f. Dissertação (Mestrado em Relações Internacionais) Universidade de Brasília - UNB, Brasília, 2009.

AUSSERER, Caroline. Controle em nome da proteção: análise crítica dos discursos sobre o tráfico internacional de pessoas. 2007. 170 f. Dissertação (Mestrado em Relações Internacionais) - Pontifícia Universidade Católica do Rio de Janeiro, Rio de Janeiro, 2007.

BATSTONE, David. Not for sale: the return of the global slave trade - and how we can fight it. $1^{\mathrm{a}}$ ed. rev. New York: Harper-Collins Publishers, 2010.

BAUCHÉ, Hugo Daniel. Trata de personas: cosificación y negociación de la persona como sujeto de derecho. Buenos Aires: Ediciones Jurídicas, 2010.

BECHARA, Fábio Ramazzini. Cooperação jurídica internacional em matéria penal: eficácia da prova produzida no exterior. São Paulo: Saraiva, 2011.

BITENCOURT, Cezar Roberto. Tratado de direito penal. $12^{\mathrm{a}}$ ed. v. 2. São Paulo: Saraiva, 2012 .

Tratado de direito penal. $6^{\text {a }}$ ed. vol. 4. São Paulo: Saraiva, 2012. 
BOIX REIG, Javier (dir.). Derecho penal: parte especial. v. 1. Madrid: Iustel, 2010.

CARNEIRO, Eliana Faleiros Vendramini. O monitoramento das políticas públicas no enfrentamento ao tráfico de pessoas. (no prelo)

CARNEIRO, José Reinaldo; MESSA, Ana Flávia (coord.). Crime organizado. São Paulo: Saraiva, 2012.

CASTELO BRANCO, Vitorino Prata. O advogado diante dos crimes sexuais. São Paulo: Sugestões Literárias, 1978.

CERNICCHIARO, Luiz Vicente. Dicionário de direito penal. São Paulo: Bushatsky, 1974.

CONTE, Maria Irene De. A ponte sobre o rio Oiapoque: uma ponte "transoceânica" entre o Brasil e a França; o MERCOSUL e a União Europeia? 2007. 145 f. Dissertação (Mestrado em Geografia Humana) - Universidade de São Paulo - USP, São Paulo, 2007.

COOPERAÇÃO e coordenação policial no MERCOSUL e Chile para o enfrentamento ao tráfico de pessoas: informações básicas. Brasil: OIT Escritório Brasil, 2009.

COSTA ANDRADE, Manuel da. Consentimento e acordo em direito penal: contributo para a fundamentação de um paradigma dualista. Coimbra: Coimbra Editora, 1991.

COSTA JÚNIOR, Paulo José da; COSTA, Fernando José da. Curso de direito penal. 12a ed. São Paulo: Saraiva, 2010.

CUNHA, Rogério Sanches et. al. Comentários à reforma criminal de 2009 e à Convenção de Viena sobre o Direito dos Tratados. São Paulo: RT, 2009.

DELMANTO, Celso et al. Código Penal comentado. $8^{a}$ ed. São Paulo: Saraiva, 2010.

DIAS, Jorge de Figueiredo (dir.). Comentário Conimbricense do Código Penal: Parte Especial. t. I. Coimbra: Coimbra Editora, 1999. 
DIAS, Jorge de Figueiredo. Direito penal - parte geral. t. 1. $1^{\mathrm{a}}$ ed. São Paulo: Revista dos tribunais, 2007 ( $2^{\mathrm{a}}$ ed. Coimbra).

DIMENSTEIN, Gilberto. Meninas da noite: a prostituição de meninas-escravas no Brasil. $16^{\mathrm{a}}$ ed. São Paulo: Ática, 2009.

ELUF, Luiza Nagib. Crimes contra os costumes e assédio sexual. São Paulo: Jurídica Brasileira, 1999.

ESER, Albin et. al. De los delitos y de las victimas. Buenos Aires: Ad-Hoc, 1992.

ESTEFAM, André. Crimes sexuais: comentários à Lei n. 12.015/2009. São Paulo: Saraiva, 2009.

ESTELLITA, HELOÍSA. Integração regional e direito penal. 2004. 241 f. Tese (Doutorado em Direito Penal) - Universidade de São Paulo - USP, São Paulo, 2004.

ESTRELA, Tatiana Silva. O enfrentamento do tráfico de pessoas para fins de exploração sexual no Brasil: trajetórias e desafios. 2007. 156 f. Dissertação (Mestrado em Política Social) - Universidade de Brasília - UNB, Brasília, 2007.

FARIA, Bento de. Código Penal brasileiro comentado. v. VI. $2^{\mathrm{a}}$ ed. Rio de Janeiro: Record, 1959.

FARIA, Maria Paula Bonifácio Ribeiro de. Aspectos jurídico-penais dos transplantes. Universidade Católica Portuguesa Editora: Porto, 1995.

FEFERBAUM, Marina. Proteção internacional dos direitos humanos: análise do sistema africano. São Paulo: Saraiva, 2011.

FEINBERG, Joel. Harm to self: the moral limits of the criminal law. v. 3. New York: Oxford University Press, 1986. 
FELLINI, Zulita. Delito de trata o tráfico de niños. $2^{\mathrm{a}}$ ed. Buenos Aires: Hammurabi, 2007.

FERRAZ, Esther de Figueiredo. Prostituição e criminalidade feminina. São Paulo, s. I., 1976.

FLORES, Theresa L. The slave across the street: the true story of how an American teen survived the world of human trafficking. Idaho: Ampelon Publishing, 2010.

FONSECA, Guido. História da prostituição em São Paulo. São Paulo: Editora Resenha Universitária, 1982.

FRAGOSO, Heleno Cláudio. Lições de direito penal: parte especial. v. 3. $1^{\text {a }}$ ed. São Paulo: Bushatsky, 1959.

FRANCO, Alberto Silva; STOCO, Rui (coords.). Código Penal e sua interpretação. $8^{\mathrm{a}}$ ed. São Paulo: Revista dos Tribunais, 2007.

FREYRE, Gilberto. Casa-grande \& senzala. 51ª ed. São Paulo: Global, 2006.

FÜHRER, Maximiliano Roberto Ernesto. Novos crimes sexuais: com a feição instituída pela Lei n. 12.015, de 7-8-2009. São Paulo: Malheiros, 2009.

GARCÍA ARÁN, Mercedes (coord.). Trata de personas y explotación sexual. Granada: Comares, 2006.

GORENDER, Jacob. O escravismo colonial. $5^{\text {a }}$ ed. São Paulo: Fundação Perseu Abramo, 2011.

GRECO, Alessandra Orcesi Pedro. A autocolocação da vítima em risco. São Paulo: Revista dos Tribunais, 2004.

GRECO, Alessandra Orcesi Pedro; RASSI, João Daniel. Crimes contra a dignidade sexual. $2^{\mathrm{a}}$ ed. São Paulo: Atlas, 2011. 
GRECO, Rogério. Curso de direito penal: parte especial. v. III. $8^{\mathrm{a}}$ ed. Niterói: Impetus, 2011 .

. Direito penal do equilíbrio: uma visão minimalista do direito penal. $4^{\mathrm{a}}$ ed. Niterói: Impetus, 2010.

GUSMÃO, Chrysólito Chaves de. Dos crimes sexuais. 5a ed. Rio de Janeiro: Freitas Bastos, 1981.

HART, H. L. A., Direito, liberdade e moralidade. Trad. Gérson Pereira dos Santos. Porto Alegre: Sérgio Antonio Fabris Editor, 1987.

HAZEU, Marcel (coord.). Pesquisa trinacional sobre tráfico de mulheres do Brasil e da República Dominicana para o Suriname: uma intervenção em rede. Belém: Sodireitos, 2008.

HUNGRIA, Nélson; LACERDA, Romão Côrtes de. Comentários ao Código Penal. v. VIII. $3^{\text {a }}$ ed. Rio de Janeiro: Forense, 1956.

JANKOV, Fernanda Florentino Fernandez. Direito internacional penal: mecanismo de implementação do Tribunal Penal Internacional. São Paulo: Saraiva, 2009.

JESUS, Damásio E. de. Direito penal: parte especial. v. 3. $20^{\mathrm{a}}$ ed. São Paulo: Saraiva, 2011.

_. Tráfico internacional de mulheres e crianças - Brasil. São Paulo: Saraiva, 2003.

KARA, Siddharth. Sex trafficking: inside the business of modern slavery. New York: Columbia University Press, 2009.

KRISTOF, Nicholas; WUDUNN, Sheryl. Metade do céu: transformando a opressão em oportunidades para as mulheres do mundo todo. Trad. Sonia Augusto. Osasco: Novo Século, 2011. 
LANDINI, Tatiana Savoia; OLIVEIRA, Marina P. P. (org.). Enfrentamento ao tráfico de pessoas. São Paulo: IBCCrim, 2008.

LAURENZO COPELLO, Patrícia (coord.). Inmigración y derecho penal: bases para un debate. Valencia: Tirant lo Blanch, 2002.

LEAL, Maria Lúcia; LEAL, Maria de Fátima P. (org.). Pesquisa sobre Tráfico de Mulheres, Crianças e Adolescentes para fins de Exploração Sexual Comercial PESTRAF: Relatório Nacional - Brasil. Brasília: CECRIA, 2002.

MACHADO, Maíra Rocha. O plano local e supraestatal de gestão de problemas $e$ conflitos internacionais: o direito moderno em face da internacionalização do campo jurídico. 2003. 254 f. Tese (Doutorado em Filosofia e Teoria Geral do Direito) Universidade de São Paulo, São Paulo, 2003.

MANUAL de capacitação sobre enfrentamento ao tráfico de pessoas. Brasil: OIT Escritório Brasil, 2009.

MARCÃO, Renato; GENTIL, Plínio. Crimes contra a dignidade sexual: comentários ao Título VI do Código Penal. São Paulo: Saraiva, 2011.

MARINUCCI, Roberto; FARIAS, Yara; SANTIN, Terezinha (coord.). Trajetórias interrompidas: cidadãos brasileiros deportados e não admitidos. Brasília: CSEM/IMDH/PBE, 2009.

MARTINELLI, João Paulo Orsini. Paternalismo jurídico-penal. 2010. 264 f. Tese (Doutorado em Direito Penal) - Universidade de São Paulo, São Paulo, 2010.

MARWELL, Tatiana Eulálio Dantas Guedes. O tratamento jurídico-penal ao tráfico internacional de pessoas para fins sexuais no Brasil à luz da Convenção de Palermo. 2009. 165 f. Dissertação (Mestrado em Direito Internacional e Econômico) - Universidade Católica de Brasília, Brasília, 2009. 
MARZAGÃO JÚNIOR, Laerte (coord.). Tráfico de pessoas. São Paulo: Quartier Latin, 2010.

MARZAGÃO JÚNIOR, Laerte. Assédio sexual e seu tratamento no direito penal. São Paulo: Quartier Latin, 2006.

MAYORDOMO RODRIGO, Virginia. El delito de tráfico ilegal e inmigración clandestina de personas. Madri: Iustel, 2008.

MENDES, Gilmar Ferreira; COELHO, Inocêncio Mártires; BRANCO, Paulo Gustavo Gonet. Curso de direito constitucional. $4^{\mathrm{a}}$ ed. São Paulo: Saraiva, 2009.

MIR PUIG, Santiago. Direito penal: fundamentos e teoria do delito. Tradução Cláudia Viana Garcia e José Carlos Nobre Porciúncula Neto. São Paulo: Revista dos Tribunais, 2007.

MIR PUIG, Santiago; CORCOY BIDASOLO, Mirentxu (dir.). Protección penal de los derechos de los trabajadores: seguridad en el trabajo, tráfico ilegal de personas e inmigración clandestina. Buenos Aires: Editorial Ibdef, 2009.

MIRABETE, Júlio Fabbrini; FABBRINI, Renato N. Código Penal interpretado. $7^{\mathrm{a}}$ ed. São Paulo: Atlas, 2011.

NABUCO, Joaquim. O abolicionismo. São Paulo: Publifolha, 2000. (Disponível em: $<$ http://dominiopublico.gov.br>.)

NATSCHERADETZ, Karl Prelhaz. O direito penal sexual: conteúdo e limites. Coimbra: Almedina, 1985.

NIREMPERGER, Zunilda; RONDAN; Francisco. Mercaderes de vida: una visión histórica, sociológica y jurídica del delito de trata de personas. Resistencia: ConTexto, 2010. 
NORONHA, Edgard Magalhães. Crimes contra os costumes: comentários aos arts. 213 a 226, e 108, VIII, do Código Penal. São Paulo: Saraiva, 1943.

. Direito penal. v. 3. 25 a ed. São Paulo: Saraiva, 2000.

NUCCI, Guilherme de Souza. Crimes contra a dignidade sexual. $2^{\mathrm{a}}$ ed. São Paulo, Revista dos Tribunais, 2010.

ONASSIS, Elena Florencia. Trata de personas: la esclavitud del siglo XXI. Córdoba: Lerner, 2011.

ORTS BERENGUER, Enrique; SUÁREZ-MIRA RODRÍGUEZ, Carlos. Los delitos contra la libertad e indemnidad sexuales. Valencia: Tirant lo Blanch, 2001.

PASCHOAL, Janaína Conceição. Constituição, criminalização e direito penal mínimo. São Paulo: Revista dos Tribunais, 2003.

PÉREZ CEPEDA, Ana Isabel. Globalización, tráfico internacional ilícito de personas y derecho penal. Granada: Editorial Comares, 2004.

PESQUISA em tráfico de pessoas. Parte 3. Brasília: SNJ/OIT, 2007.

PIERANGELI, José Henrique. Códigos Penais do Brasil: evolução histórica. $2^{\mathrm{a}}$ ed. São Paulo: Revista dos Tribunais, 2001.

_. O consentimento do ofendido: na teoria do delito. 2. ed. São Paulo: Revista dos Tribunais, 1995.

PIOVESAN, Flávia. Direitos humanos e o direito constitucional internacional. $13^{\mathrm{a}}$ ed. São Paulo: Saraiva, 2012.

_. Temas de direitos humanos. $4^{\mathrm{a}}$ ed. São Paulo: Saraiva, 2010. 
PRADO, Luiz Regis. Bem jurídico-penal e Constituição. $3^{\text {a }}$ ed. São Paulo: Revista dos Tribunais, 2003.

RASSI, João Daniel. Comportamento da vítima no direito penal sexual. 2006. 173 f. Dissertação (Mestrado em Direito Penal) - Universidade de São Paulo - USP, São Paulo, 2006.

REALE, Miguel. Filosofia do direito. 20 ed. São Paulo: Saraiva, 2002.

RELATÓRIO Final da Comissão Parlamentar Mista de Inquérito: criada por meio do Requerimento n. 2, de 2003, com a finalidade de investigar as situações de violência e redes de exploração sexual de crianças e adolescentes. Brasília, 2004.

RELATÓRIO Final de Execução do Plano Nacional de Enfrentamento ao Tráfico de Pessoas. Brasília: Ministério da Justiça/SNJ, 2010.

RELATÓRIO Global da OIT, 2005. Disponível em: <http://www.oit.org.br/sites/default/files/topic/forced_labour/pub/relatorio_global_2005_al ianca_contra_trabalho_forcado_316.pdf>. Acesso em 15 nov. 2011.

RELATÓRIO Global da OIT, 2009. Disponível em: <http://www.oit.org.br/sites/default/files/topic/forced_labour/pub/custo_da_coercao_308.p df >. Acesso em 2: out. 2011.

RELATÓRIO Parcial da Comissão Parlamentar de Inquérito: criada pelo Requerimento n. 226, de 2011, com a finalidade de investigar o tráfico nacional e internacional de pessoas. Brasília, 2011.

ROXIN, Claus. A proteção de bens jurídicos como função do direito penal. Trad. André Luís Callegari e Nereu José Giacomolli. Porto Alegre: Livraria do Advogado Editora, 2006.

Estudos de direito penal. Trad. Luís Greco. $2^{\mathrm{a}}$ ed. Rio de Janeiro: Renovar, 2008. 
SARLET, Ingo Wolfgang. Dignidade da pessoa humana e direitos fundamentais. $7^{\mathrm{a}}$ ed. Porto Alegre: Livraria do Advogado, 2009.

SERRA, Carlos (Dir.). Tatá papá, tatá mamã: tráfico de menores em Moçambique. Maputo: Imprensa Universitária, 2006.

SERRA CRISTÓBAL, Rosario; LLORIA GARCÍA, Paz. La trata sexual de mujeres: de la represión del delito a la tutela de la víctima. Madri: Ministerio de Justicia, 2007.

SERRANO GÓMEZ, Alfonso; SERRANO MAÍlLO, Alfonso. Derecho penal: parte especial. $15^{\mathrm{a}}$ ed. Madri: Dykinson, 2010.

SILVA, De Plácido e. Vocabulário jurídico. Rio de Janeiro: Forense, 1996.

SILVA, Tadeu Antônio Dix. Crimes sexuais: reflexões sobre a Nova Lei n. 11.106/2005. Leme: J. H. Mizuno, 2006.

SILVEIRA, Renato de Mello Jorge. Crimes sexuais: bases críticas para a reforma do direito penal sexual. São Paulo: Quartier Latin, 2008.

SIQUEIRA, Galdino. Direito penal brazileiro. v. II. Brasília: Senado Federal, 2003.

SISTEMATIZAÇÃO da experiência de um ano de funcionamento do posto. Brasília: Ministério da Justiça/SNJ, UNODOC, 2009.

TESCARI, Adriana Sader. Violência sexual contra a mulher em situação de conflito armado. Porto Alegre: Sérgio Antônio Fabris Editor, 2005.

TOLEDO, Francisco de Assis. Princípios básicos de direito penal. $5^{\mathrm{a}}$ ed. São Paulo: Saraiva, 1994.

TRÁFICO de pessoas: critérios e fatores de identificação de supostas vítimas. Brasília: Ministério da Justiça/SNJ, UNODC, 2009. 
TRÁFICO de pessoas: pesquisa e diagnóstico do tráfico de pessoas para fins de exploração sexual e de trabalho no estado de Pernambuco. Recife: SNJ, SENASP, UNODC, Governo do Estado de Pernambuco, 2009.

TRAFFICKING in Persons Report, Estados Unidos, 2011. Disponível em: <http://www.state.gov/g/tip/rls/tiprpt/2011/index.htm>. Acesso em: 1 dez. 2011.

TRAFFICKING in persons to Europe for sexual exploitation. Disponível em: $<$ http://www.unodc.org/southerncone/pt/trafico-de-pessoas/publicacoes.html> Acesso em: 16 jan. 2011.

TRINDADE, Eliane. As meninas da esquina. $3^{\mathrm{a}}$ ed. Rio de Janeiro: Record, 2010.

VON LISZT, Franz. Tratado de direito penal alemão. Trad. José Hygino Duarte Pereira. Rio de Janeiro: Briguiet, 1899. Edição fac-sim. Brasília: Senado Federal/STJ, 2006.

ZORRILLA, Maider. La Corte Penal Internacional ante el crimen de violencia sexual. Cadernos Deusto de Derechos Humanos - Universidad de Deusto, Bilbao, n. 34, 2005.

ZUGALDÍA ESPINAR, José Miguel (dir.). El derecho penal ante el fenómeno de la inmigración. Valencia: Tirant lo Blanch, 2007.

\section{$\underline{\text { Artigos: }}$}

AGUSTÍN, Laura Ma $\mathrm{M}^{\mathrm{a}}$. La industria del sexo, los migrantes y la familia europea. Cadernos Pagu, Campinas, n. 25, jul./dez. 2005.

ANDERSON, B.; DAVIDSON, J. Trafficking - a demand led problem? A multi-country pilot study. Disponível em: <http://www.childtrafficking.com/Docs/anderson_o_connel_davidson_2004_trafficking_a _demand_led_p_1.pdf>. Acesso em: 3 dez. 2010. 
ARONOWITZ, Alexis. Trafficking in human beings: an international perspective. In: SIEGAL, Dina et al. (coord.). Global organized crime: trends and developments. Dordrecht: Kluwer Academic Publishers, 2003.

ASBRAD. Direitos humanos e gênero no cenário da migração e do tráfico internacional de pessoas. Cadernos Pagu, Campinas, n. 31, jul./dez. 2008.

BARROS, Marco Antonio de. Tráfico de pessoas para fim de exploração sexual e a adoção internacional fraudulenta. Disponível em: <http://www.cnj.jus.br/dpj/cji/handle/26501/1883>. Acesso em: 26 dez. 2011.

BRAGON, Rayder. "Exportadora" de imigrantes, Governador Valadares (MG) combate ação de aliciadores. UOL Notícias, 2 set. 2010. Disponível em: $<$ http://noticias.uol.com.br/cotidiano/2010/09/02/exportadora-de-imigrantes-governadorvaladares-mg-combate-acao-de-aliciadores.jhtm>. Acesso em: 11 jan. 2011.

CALLEGARI, André Luís. A concretização dos direitos constitucionais: uma leitura dos princípios da ofensividade e da proporcionalidade nos delitos sexuais. In: STRECK, Lenio Dias (org.). Direito penal em tempos de crise. Porto Alegre: Livraria do Advogado, 2007, p.133-150.

CALZARETTI, Cinzia; CARABELLESE, Felice; CATANESI, Roberto. Il traffico di donne finalizzato allo sfruttamento della prostituzione in Italia. Rassegna Italiana di Criminologia, Milano, v. 16, n. 4, p. 641-672, out. 2005.

CASTILHO, Ela Wiecko V. de. A criminalização do tráfico de mulheres: proteção das mulheres ou reforço da violência de gênero? Cadernos Pagu, Campinas, n. 31, jul./dez. 2008.

A legislação penal brasileira sobre tráfico de pessoas e imigração ilegal/irregular frente aos Protocolos adicionais à Convenção de Palermo. Disponível em: $<$ http://pfdc.pgr.mpf.gov.br/informacao-e-comunicacao/informativos-pfdc/edicoes-de2006/maio-2006/seminario_cascais.pdf/view>. Acesso em: 16 nov. 2010. 
Tráfico de pessoas: da Convenção de Genebra ao Protocolo de Palermo. Disponível em: <pfdc.pgr.mpf.gov.br/publicacoes/docs_artigos/artigo_trafico_de_pessoas.pdf; http://pfdc.pgr.mpf.gov.br/atuacao-e-conteudos-de-apoio/publicacoes/trafico-depessoas/artigo_trafico_de_pessoas.pdf/view>. Acesso em: 16 nov. 2010.

COSTA, Fernando José da. Do tráfico interno de pessoas. In: REALE JÚNIOR, Miguel; PASCHOAL, Janaína (coord.). Mulher e direito penal. Rio de Janeiro: Forense, 2007.

COSTA, José de Faria. A globalização e o tráfico de seres humanos: o pêndulo trágico da história e o direito penal. In: Direito penal e globalização: reflexões não locais e pouco globais. Coimbra: Coimbra Editora, 2010.

COSTA, Patrícia Trindade Maranhão. A construção da masculinidade e a banalidade do mal: outros aspectos do trabalho escravo contemporâneo. Cadernos Pagu, Campinas, n. 31, jul./dez. 2008.

DAUNIS RODRÍGUES, Alberto. La promoción del tráfico ilegal de personas: aspectos jurídicos y policiales. In: SANZ MULAS, Nieves (coord.). El desafío de la criminalidad organizada. Granada: Comares, 2006.

DE SANCTIS, Fausto Martins. Tráfico internacional de pessoas: tipo penal e o consentimento do ofendido. In: REALE JÚNIOR, Miguel; PASCHOAL, Janaína (coord.). Mulher e direito penal. Rio de Janeiro: Forense, 2007.

DÍAZ BARRERO, Gloria Patricia. Stripers, erotic and exotic dancers: inmigration and identity in the construction of the Canadian nation-State. Cadernos Pagu, Campinas, n. 25, jul./dez. 2005.

DÍEZ RIPOLLÉS, José Luis. El objeto de protección del nuevo derecho penal sexual. Revista de Derecho Penal y Criminología, Madrid, 2a época, n. 6, p.69-101, jul. 2000.

DOEZEMA, Jo. Loose women or lost women? The re-emergence of the myth of 'white slavery' in contemporary discourses of 'trafficking in women'. Disponível em: <http://www.walnet.org/csis/papers/doezema-loose.html>. Acesso em: 28 nov. 2010. 
DOSSIÊ: Gênero no Tráfico de Pessoas. Cadernos Pagu, Campinas, n. 31, jul./dez. 2008.

DUARTE, Jorge Dias. Tráfico e exploração sexual de mulheres. Revista do Ministério Público, n. 85. Lisboa, 2001, p. 51-69.

EKBERG, Gunilla. The Swedish law that prohibits the purchase of sexual services: best practices for prevention of prostitution and trafficking in human beings. Violence against women. $\quad$ v. $10 . \quad$ out. $2004 . \quad$ Disponível em: <http://action.web.ca/home/catw/attach/Ekberg.pdf>. Acesso em: 28 nov. 2010.

FARIA, Thaís Dumêt. Mulheres no tráfico de pessoas: vítimas e agressoras. Cadernos Pagu, Campinas, n. 31, jul./dez. 2008.

FAVARO, Thomas. Mudanças na vitrine. Revista Veja, edição 2.050, 5 mar. 2008. Disponível em: <http://veja.abril.com.br/050308/p_098.shtml>. Acesso em: 10 mar. 2011.

FELICIANO, Guilherme Guimarães. O tráfico de pessoas. Boletim Instituto Manoel Pedro Pimentel. São Paulo, n. 6, ano II, p. 26-27, dez. 1998.

GARCÍA DE PAZ, Isabel Sánchez. Concepto y perfil criminológico de la delincuencia transnacional organizada. Revista Peruana de Ciencias Penales, Lima, n. 17, p.499-551, 2005.

GOMES, Luiz Flávio. Crimes contra a dignidade sexual e outras reformas penais. Disponível em: <http://www.lfg.com.br>. Acesso em: 14 set. 2009.

GRECO, Alessandra Orcesi Pedro. Delegacia da mulher, vitimodogmática, autocolocação da vítima em risco e consentimento do ofendido. In: REALE JÚNIOR, Miguel; PASCHOAL, Janaína (coord.). Mulher e direito penal. Rio de Janeiro: Forense, 2007.

GRECO FILHO, Vicente. Crime: essência e técnica. Boletim Instituto Manoel Pedro Pimentel. São Paulo, n. 21, ano V, p. 11-12, jul.-set. 2002. 
. Tipicidade, bem jurídico e lavagem de valores. In: COSTA, José de Faria; SILVA, Marco Antonio Marques da. Direito penal especial, processo penal e direitos fundamentais: visão luso-brasileira. São Paulo: Quartier Latin, 2006.

_. Uma interpretação de duvidosa dignidade. Disponível em: $<$ http://www.grecofilho.com.br/pdfs/interpretacao_lei_dignidade_sexual.pdf>. Acesso em: 15 jan. 2011.

GRECO, Luís. Tem futuro a teoria do bem jurídico? Reflexões a partir da decisão do Tribunal Constitucional Alemão a respeito do crime de incesto ( $\$ 173$ Strafgesetzbuch) . Revista Brasileira de Ciências Criminais, n. 82. São Paulo: Revista dos Tribunais, 2010. p. 165-182.

GRUPO DAVIDA. Prostitutas, "traficadas" e pânicos morais: uma análise da produção de fatos em pesquisas sobre o "tráfico de seres humanos". Cadernos Pagu, Campinas, n. 25, jul./dez. 2005, p. 153-184.

GUSMÁN DALBORA, José Luis. La trata de personas y el problema de su bien jurídico. Revista Brasileira de Ciências Criminais, n. 71. São Paulo: Revista dos Tribunais, 2008. p. 126-146.

ILLES, Paulo; TIMOTEO, Gabrielle Louise Soares; FIORUCCI, Elaine da Silva. Tráfico de Pessoas para fins de exploração do trabalho na cidade de São Paulo. Cadernos Pagu, Campinas, n. 31, jul./dez. 2008, p. 199-217.

ISELIN, Brian; ADAMS, Melanie. Distinguishing between Human Trafficking and People Smuggling. Bangkok: UN Office on Drugs and Crime / Regional Centre for East Asia and the Pacific, 2003. Disponível em: <http://www.embraceni.org/wpcontent/uploads/2006/06/Distinguishing\%5B1\%5D1.pdf>. Acesso em: 15 nov. 2010.

JESUS, Damásio Evangelista de. Lavagem de dinheiro proveniente de tráfico internacional de mulheres e crianças não constitui crime. Revista da AJUFE, Brasília, v. 21, n. 73, p.63$68,2003$. 
JULIANO, Dolores. El trabajo sexual en la mira. Polémicas y estereotipos. Cadernos Pagu, Campinas, n. 25, jul./dez. 2005.

KARA, Siddharth. Researching the cruel world of sex trafficking in South Asia. Disponível em: <http://thecnnfreedomproject.blogs.cnn.com/2011/09/29/researching-the-cruel-worldof-sex-trafficking-in-south-asia/>. Acesso em: 2 out. 2011.

KARAM, Maria Lúcia. Violência de gênero: o paradoxal entusiasmo pelo rigor penal. Boletim IBCCrim. São Paulo, v. 14, n. 168, p. 6-7, nov. 2006.

KEMPADOO, Kamala. Mudando o debate sobre o tráfico de mulheres. Cadernos Pagu, Campinas, n. 25, jul./dez. 2005, p. 55-78.

KLEEMANS, Edward; VAN DE BUNT, H.G. The social organization of human trafficking. In: SIEGAL, Dina et al. (coord.). Global organized crime: trends and developments. Dordrecht: Kluwer Academic Publishers, 2003.

MARTINELli, João Paulo Orsini. Tráfico de pessoas e consentimento: uma breve reflexão. Boletim IBCCrim. São Paulo, v. 18, n. 221, p. 7, abr. 2011.

MÉDICI, Sérgio de Oliveira. A condição feminina na reforma penal projetada de 1999. In: REALE JÚNIOR, Miguel; PASCHOAL, Janaína (Coord.). Mulher e direito penal. Rio de Janeiro: Forense, 2007.

MENDES, Paulo de Sousa. Tráfico de pessoas. In: Jornadas sobre a Revisão do Código Penal - 27 e 28 de Setembro de 2007 - Centro de Estudos Judiciários. Disponível em: <http://www.estig.ipbeja.pt/ ac_direito/traficopessoassm.pdf>. Acesso em: 14 nov. 2010.

MENEZES, Lená Medeiros de. O tráfico internacional de mulheres no debut e fin-desiecle. In: Discursos sediciosos - crime, direito e sociedade. Ano 2, n. 4. Rio de Janeiro: Freitas Bastos, 1997, p. 171-178.

NEVES, João Ataíde das. Avançar no combate ao tráfico de seres humanos. Revista Sub Judice - Justiça e Sociedade. n. 26. Coimbra, 2003, p. 26-42. 
NIETO OLIVAR, José Miguel. A angústia dos corpos indóceis: prostituição e conflito armado na Colômbia contemporânea. Cadernos Pagu, Campinas, n. 31, jul./dez. 2008. OLIVEIRA, Ana Sofia Schimidt. Vitimologia e mulher. In: REALE JÚNIOR, Miguel; PASCHOAL, Janaína (coord.). Mulher e direito penal. Rio de Janeiro: Forense, 2007.

OLIVEIRA, Marina P. P. Iniciativa global contra o tráfico de pessoas: uma briga pelas consciências. Boletim IBCCrim, São Paulo, ano 15, n. 176, p. 13-14, jul. 2007.

. Sobre armadilhas e cascas de banana: uma análise crítica da administração de justiça em temas associados aos direitos humanos. Cadernos Pagu, Campinas, n. 31, jul./dez. 2008.

PADILLA ALBA, Herminio Ramón. El delito de tráfico ilegal de personas tras su reforma por la LO 11/2003, de 29 de septiembre. La Ley Penal: revista de derecho penal, procesal y penitenciario, Madrid, v. 2, n. 14, p. 5-23, mar. 2005.

PASCHOAL, Janaína Conceição. A escravidão e a interpretação viciada da lei. Revista do Curso de Mestrado em Direito da Faculdade Integradas Toledo, Araçatuba, v. 4, n. 1, p. 43 a 80, jul. 2004.

PATTO, Pedro Maria Godinho Vaz. O crime de tráfico de pessoas no código penal revisto: análise de algumas questões. Disponível em <http://www.cej.mj.pt/cej/home/home.php>. Acesso em: 21 set. 2010.

PEREIRA, Cristiana Schettini. Lavar, passar e receber visitas: debates sobre a regulamentação da prostituição e experiências de trabalho sexual em Buenos Aires e no Rio de Janeiro, fim do século XIX. Cadernos Pagu, Campinas, n. 25, p. 25-54, jul./dez. 2005.

PIMENTEL, Geyza Alves; OLIVEIRA, Rafael da Silva. Tráfico de mulheres para fim de exploração sexual comercial na fronteira Brasil-Venezuela: o caso da BR-174. In: LEAL, Maria Lúcia Pinto; LEAL, Maria de Fátima Pinto; LIBÓRIO, Renata Maria Coimbra 
(org.). Tráfico de Pessoas e Violência Sexual. Brasília: Leal Produções \& Publicações, 2007, v. 1, p. 59-73.

PIOVESAN, Flávia. Tráfico de pessoas para fins de exploração sexual. Disponível em: <http://www.justica.sp.gov.br/Modulo.asp?Modulo=595>. Acesso em: 15 dez. 2011.

PISCITELLI, Adriana. Entre as "máfias" e a "ajuda": a construção de conhecimento sobre tráfico de pessoas. Cadernos Pagu, Campinas, n. 31, jul./dez. 2008, p. 29-63.

Sujeição ou subversão: migrantes brasileiras na indústria do sexo na Espanha. In: Revista Histórias e Perspectivas, n. 35. Uberlândia, jul.-dez. 2006. Disponível em: $<$ http://www.historiaperspectivas.inhis.ufu.br/index.php>. Acesso em: 5 jan. 2011.

POLAINO NAVARRETE, Miguel. Introducción a los delitos contra la honestidad. Anales de la Universidad Hispalense, Sevilla, n. 25, 1975.

POLAINO-ORTS, Miguel. Alegato en favor de un tratamiento jurídico-penal unitario para los casos de acuerdo y consentimiento como causas de atipicidad. Cuadernos de Política Criminal, Madrid, n. 82, p. 163-204, 2004.

POZUELO PÉREZ, Laura. Tráfico de personas y explotación sexual. In: CUERDA RIEZU, Antonio (dir.). La respuesta del derecho penal ante los nuevos retos. Madrid: Dykinson, 2006.

RASSI, João Daniel. A questão da vulnerabilidade no direito penal sexual brasileiro. (no prelo)

RAYMOND, Janice. Trafficking, prostitution and the sex industry: the Nordic legal model. jul. 2010.2 Disponível em: $<$ http://action.web.ca/home/catw/readingroom.shtml?x=130078\&AA_EX_Session=d29d9c 2ba7f2b721cf12e01bacf933ea>. Acesso em: 15 jan. 2011.

REALE JÚNIOR, Miguel. O escravo como não sujeito de direitos. (no prelo) 
RODRIGUES, Anabela Miranda. O papel dos sistemas legais e a sua harmonização para a erradicação das redes de tráfico de pessoas. Revista do Ministério Público, n. 84. Lisboa, 2000, p. 15-29.

SALES, Lília Maia de Morais; ALENCAR, Emanuela Cardoso Onofre de. Tráfico de seres humanos, migração, contrabando de migrantes, turismo sexual e prostituição: algumas diferenciações. Novos Estudos Jurídicos, Itajaí, v. 13, n. 1, p. 29-42, jan./jun. 2008.

SALGADO, Daniel de Resende. O bem jurídico tutelado pela criminalização do tráfico internacional de seres humanos. Disponível em: <http://www.prsp.mpf.gov.br/prdc/areade-atuacao/escravidao-e-trafico-de-seres-humanos>. Acesso em: 13 dez. 2011.

SANTOS, Eloísa Gabriel dos; SILVA, Maria do Socorro Nunes da; SIQUEIRA, Priscila (org.). Tráfico de pessoas: uma abordagem política. São Paulo: SMM, 2007. Disponível em <http://www.smm.org.br/publicacoes.asp>. Acesso em: 10 dez. 2010.

SHECAIRA, Sérgio Salomão; SILVEIRA, Renato de Mello Jorge. O tráfico internacional de mulheres e de crianças. Boletim IBCCrim. São Paulo, v.10, n.112, p. 3-4, mar. 2002.

SILVEIRA, Renato de Mello Jorge. Por um novo direito penal sexual. Revista Brasileira de Ciências Criminais, n. 33. São Paulo: Revista dos Tribunais, 2001. p. 133-158.

SIQUEIRA, Priscila. Tráfico de mulheres: demanda, oferta, impunidade. São Paulo: SMM, 2004. Disponível em <http://www.smm.org.br/publicacoes.asp>. Acesso em: 10 dez. 2010.

TAGLE LÓPEZ, Erick Gómez. Prostituición y tráfico de mujeres y niños. Iter Criminis Revista de Ciencias Penales, México, 2009, n. 7, cuarta época.

TEIXEIRA, Flávia do Bonsucesso. L'Italia dei Divieti: entre o sonho de ser europeia e o babado da prostituição. Cadernos Pagu, Campinas, n. 31, jul./dez. 2008.

TORRES, Izabelle; COSTA, Flávio. Tráfico de pessoas. Revista Isto é, edição 2.189, 21 out. 2011. Disponível em: 
$<$ http://www.istoe.com.br/reportagens/170188_TRAFICO+DE+PESSOAS>. Acesso em: 19 dez. 2011.

VILLACAMPA ESTIARTE, Carolina. Consideraciones acerca de la reciente modificación del delito de tráfico de personas. Revista Penal, Barcelona, n. 14, p. 182-208, jul. 2004.

WHITE, Andrew; SCHMALFUSS, Conny; BRAUN, Sebastian. Strafbarkeit des Menschenhandels nach der Neuregelung der $\$ \S 232$ ff. StGB. Disponível em: $<$ http://docs.google.com/viewer?a=v\&q=cache:3m_9ZGI2UGkJ:heinrich.rewi.huberlin.de/Kriminalpolitisches\%2520Forum/Menschenhandel.pdf>. Acesso em: 16 mar. 2011. (Tradução com o auxílio do Professor Gerhard Brodt, Goethe-Institut, São Paulo).

\section{Filmes e documentários $^{523}$ :}

AFFECTED for life. Direção: Anja Dalhoff. Produção: Gitte Randlov. Edição: Dumitru Marian. $2009 . \quad$ UNODC, em: <http://www.unodc.org/unodc/en/multimedia.html?vf=/documents/video/2009/Affected_fo r_Life_-_Long.flv>. Acesso em: 24 dez. 2011. (tráfico de pessoas e de migrantes)

A INFORMANTE. Direção: Larysa Kondracki. Intérpretes: Rachel Weisz; Nikolaj Lie Kaas e outros. Roteiro: Larysa Kondracki e Eilis Kirwan. Música: Mychael Danna. Alemanha/Canadá: Imagem filmes, 2010. 1 DVD (112 min), color. (tráfico sexual)

A PASSAGEM. Direção: Mark Heller. Roteiro: Neil Jackson. Intérpretes: Stephen Dorff; Neil Fluellen; Sarai Givaty e outros. Roteiro: Robert Mark Kamen; Luc Besson. Estados Unidos: Paramount Pictures, 2007. 1 DVD (100 min), color. (tráfico de órgãos)

ANJOS do sol. Direção: Rudi Lagemann. Produção: Luiz Leitão; Juarez Precioso e Rudi Lagemann. Intérpretes: Fernanda Carvalho; Antonio Calloni; Chico Diaz; Vera Holtz;

\footnotetext{
${ }^{523}$ Até 31-12-2011 não estavam disponíveis para venda os documentários: Sex+Money: a national search for human worth (trailer disponível em: http://sexandmoneyfilm.com/); e Playground, de Libby Spears (excertos do filme disponíveis em: http://www.playgroundproject.com/film/).
} 
Darlene Glória; Otávio Augusto e outros. Roteiro: Rudi Lagemann. Música: Felipe Radicetti; Flu e Nervoso. Brasil: Paris Filmes, 2006. 1 DVD (90 min), color. (tráfico sexual)

BEM-VINDO. Direção: Philippe Lioret. Produção: Christophe Rossignon. Intérpretes: Vincent Lindon; Firat Ayverdi; Audrey Dana e outros. Roteiro: Philippe Lioret. França: Imovision, 2009. 1 DVD (90 min), color. (contrabando de migrantes)

BUSCA implacável. Direção: Pierre Morel. Produção: Luc Besson. Intérpretes: Liam Neeson; Maggie Grace; Famke Janssen e outros. Roteiro: Robert Mark Kamen; Luc Besson. Música: Martin Boissau. França / Estados Unidos/UK: Twentieth Century Fox, 2008. 1 DVD (93 min), color. (tráfico sexual)

CINDERELAS, lobos e um príncipe encantado. Direção e Produção Executiva: Joel Zito Araújo. Roteiro: Joel Zito Araújo e José Carvalho. Brasil, 2008. 1 DVD (107 min), color. (Documentário ainda não comercializado. Cópia disponibilizada pela Produtora Casa de Criação Cinema, com a anuência do diretor, em janeiro/2011).

COISAS belas e sujas. Direção: Stephen Frears. Produção: Robert Jones e Tracey Seaward. Intérpretes: Audrey Tautou; Sergi López; Chiwetel Ejiofor; Sophie Okonedo e outros. Roteiro: Steven Knight. Reino Unido: Miramax, 2002. 1 DVD (97 min), color. (tráfico de órgãos)

DESAPARECIDOS. Direção: Marco Kreuzpaintner. Produção: Rosilyn Heller e Roland Emmerich. Intérpretes: Kevin Kline; Alicja Bachleda-Curus; Paulina Gaitan; Cesar Ramos e outros. Roteiro: Jose Rivera. Estados Unidos: Paris Filmes, 2007. 1 DVD (119 min), color. (tráfico sexual)

ELDORADO: docudrama sobre tráfico de pessoas. Direção: Paula Goldman. Produção: José Gonzáles Frontana. Roteiro: Paula Goldman e Carolina Markowicz. Brasil: Selva Filmes, 2010. 1 DVD (45 min), color. (tráfico sexual/trabalho escravo)

ENCANTOS e desencantos em rede. Brasil: TV Universidade Federal de Goiás, 2011. (17 min), color. Disponível em: <http://www.youtube.com/watch?v=1tCOArJWZ9k>. Acesso em: 30 dez. 2011. (tráfico sexual) 
JORNADA pela liberdade. Direção: Michael Apted. Produção: Edward Pressman e outros. Intérpretes: Ioan Gruffudd, Albert Finney e outros. Roteiro: Steven Knight. Edição: Rick Shaine. Reino Unido/EUA: Walden Media, 2006. 1 DVD (117 min), color. (tráfico negreiro)

NASCIDOS em bordéis. Direção: Ross Kauffman e Zana Briski. Produção: Geralyn White Dreyfous. Edição: Nancy Baker e Ross Kauffman. Índia/EUA: Red Light Films, 2004. 1 DVD (86 min), color. (documentário/prostituição)

OLHO por olho. Direção: Prachya Pinkaew. Intérpretes: Kevin Bacon, Djimon Hounsou e outros. Estados Unidos: Califórnia, 2011. 1 DVD (91 min), color. (tráfico sexual)

PARA sempre Lilya. Direção: Lukas Moodysson. Produção: Lars Jonsson. Intérpretes: Oksana Akinshina, Artyom Bogucharsky e outros. Roteiro: Lukas Moodysson. Suécia/Dinamarca: Newmarket Film Group/Imovision,2002. 1 DVD (105 min), color. (tráfico sexual)

PASSAGEIROS da noite. Direção: Edward Anderson. Produção: Allan Jones e Mark Donadio. Intérpretes: Tony Curran; Michael DeMello; Cameron Goodman e outros. Roteiro: Edward Anderson. EUA: Paris Filmes, 2008. 1 DVD (106 min), color. (tráfico sexual)

SENHORES do Crime. Direção: David Cronenberg. Produção: Robert Lantos e Paul Webster. Intérpretes: Naomi Watts, Viggo Mortensen e outros. Roteiro: Steven Knight. Canadá/EUA/Inglaterra: Focus Features, 2007. 1 DVD (100 min), color. (tráfico sexual)

SONHOS roubados. Direção: Sandra Werneck. Produção: Elisa Tolomelli. Intérpretes: Nanda Costa, Amanda Diniz, Kika Farias e outros. Roteiro: Paulo Halm, Michelle Franz e outros. Brasil: Europa Filmes, 2010. 1 DVD (92 min.), color. (prostituição)

THE SELLING of innocents. Direção: Ruchira Gupta. Disponível em: $<$ http://apneaap.org/policy-work/our-resources/videos/selling-innocents-film-ruchiragupta>. Acesso em: 25 dez. 2011. (tráfico sexual) 
TRÁFICO humano. Direção: Christian Duguay. Produção: Christian Duguay; Michael Prupas e Irene Litinsky. Intérpretes: Mira Sorvino; Donald Sutherland; Remy Girard; Robert Carlyle e outros. Roteiro: Carol Doyle e Agatha Domink. Música: Normand Corbeil. Canadá / Estados Unidos: Alpha Filmes, 2005. 1 DVD (176 min), color. (tráfico sexual)

VÍDEOS sobre tráfico de pessoas produzidos pela Not for Sale. Disponível em: <http://vimeo.com/notforsale>. Acesso em: 24 dez. 2011.

VÍDEOS sobre tráfico de pessoas produzidos pelo UNODC: Disponível em: <http://www.unodc.org/unodc/en/multimedia.html?vf=/documents/video/2009/Affected_fo r_Life_-_Long.flv>. Acesso em: 24 dez. 2011.

\section{Sites de governos:}

- http://portal.mj.gov.br/data/Pages/MJ16B51547PTBRIE.htm (Ministério da Justiça - Brasil)

- http://www.mtecbo.gov.br/cbosite/pages/home.jsf (Ministério do Trabalho - Brasil)

- https://www.planalto.gov.br/ccivil_03/_Ato2004-2006/2004/Decreto/D5017.htm (Protocolo de Palermo)

- http://www.justica.sp.gov.br/ (Núcleo de Prevenção e Enfrentamento ao Tráfico de Pessoas - SP)

- http://portal.mte.gov.br/antd/ (Agenda Nacional de Trabalho Decente)

- http://www.dpf.gov.br/ (Polícia Federal)

- http://www.portalconsular.mre.gov.br/destaques/disque-denuncia-trafico-depessoas-1 (Disque-denúncia específico para o tráfico de pessoas)

- http://www.state.gov/g/tip/index.htm (US Department of State - Office to Monitor and Combat Trafficking in Persons)

- http://www.state.gov/g/tip/laws/61124.htm (Victims of Trafficking and Violence Protection Act of 2000)

- http://www.usaid.gov/ (United States Agency for International Development USAID) 
- http://www.coe.int/t/dg2/trafficking/campaign/Source/PDF_Conv197_Portuguese.p df (Convenção do Conselho da Europa relativa a Luta contra o Tráfico de Seres Humanos, de 2005)

- http://eur-lex.europa.eu/ (Base EUR-Lex, acesso ao direito da União Europeia)

\section{Sites da ONU, OEA e TPI:}

- http://www.iom.int (International Organization for Migration - IOM)

- http://www.oit.org.br/ (Organização Internacional do Trabalho - OIT)

- http://www.unodc.org/southerncone/ (United Nations Office on Drugs and Crime UNODC)

- $\quad$ http://www.un.org/ (Organização das Nações Unidas - ONU)

- http://www.ungift.org/knowledgehub/ (United Nations Global Initiative to Fight Human Trafficking - UN.GIFT)

- http://www.iin.oea.org/IIN2011/historia-instituto-interamericano-del-nino-ninaadolescente.shtml (Instituto Interamericano del niño, la niña y adolescentes - IIN)

- http://www.unescobkk.org/index.php?id=1022 (Trafficking Statistics Project)

- http://www.icc-cpi.int/Menus/ICC/Home (Tribunal Penal Internacional)

\section{Sites de organizacões civis:}

- http://productsofslavery.org/ (Anti-Slavery International's interactive map)

- http://www.stopthetraffik.org (Stop the Traffik: people shoudn't be bought \& sold)

- http://thecnnfreedomproject.blogs.cnn.com/ (The CNN Freedom Project: ending modern-day slavery)

- http://catwinternational.org/ (Coalition Against Trafficking in Women - CATW)

- http://www.gaatw.org/ (Global Alliance Against Traffic In Women - GAATW)

- http://www.notforsalecampaign.org/ (Not for Sale)

- http://www.slaverymap.org/ (Mapa da escravidão moderna, elaborado pela Not for Sale)

- http://www.love146.org/ (Love 146)

- http://www.gracehavenhouse.org/ (Grace Haven) 
- http://www.vineyardcollege.org/ (Vineyard College of Mission - Women \& Children in Crisis)

- http://www.polarisproject.org/ (Polaris Project)

- http://www.freetheslaves.net/ (Free the Slaves)

- http://www.ijm.org/ (International Justice Mission)

- http://www.sharedhope.org/Home.aspx (Shared Hope International)

- http://www.unseenuk.org/ (Unseen)

- http://www.playgroundproject.com/nest/ (Playground Project)

- http://apneaap.org/index.php (ONG indiana Apne Aap)

- http://www.prajwalaindia.com/home.html (Organização indiana Prajwala)

- http://www.camnet.com.kh/Girls-Ambitious/ (American Assistance for Cambodia Programa Girls be ambitious)

- http://www.iccwomen.org/index.php (Women's Initiatives for Gender Justice)

- http://www.nordicbalticcampaign.org/ (Nordic-Baltic Campaign against Trafficking in Women)

- http://www.hrw.org/ (Human Rights Watch)

- http://www.ecpat.net/EI/index.asp (ECPAT Internacional - End Child Prostitution, Child Pornography \& Trafficking of Children for Sexual Purposes)

- http://www.josephinebutler.org.uk/ (Site dedicado à feminista Josephine Butler)

- http://www.projetoresgatebrasil.org.br/ (Projeto Resgate)

- http://www.asbrad.com.br (Associação Brasileira de Defesa da Mulher, da Infância e da Juventude - ASBRAD)

- http://www.smm.org.br (Serviço à Mulher Marginalizada - SMM)

- http://www.traficodepessoas.org.br/ (Movimento contra o Tráfico de Pessoas MCTP)

- http://www.davida.org.br/ (Grupo DAVIDA) 